Bruna Tavares Camargos

Mario Vargas Llosa e a Teoria dos 'Demônios': Entre Obsessões, Rebeldia e Liberdade

Dissertação apresentada como requisito parcial para obtenção do grau de Mestre pelo Programa de Pósgraduação em História Social da Cultura do Departamento de História do Centro de Ciências Sociais da PUC-Rio.

Orientador: Prof. Henrique Estrada Rodrigues 
Bruna Tavares Camargos

\title{
Mario Vargas Llosa e a Teoria dos 'Demônios': Entre Obsessões, Rebeldia e Liberdade
}

\begin{abstract}
Dissertação apresentada como requisito parcial para obtenção do grau de Mestre pelo Programa de Pós-graduação em História Social da Cultura do Departamento de História do Centro de Ciências Sociais da PUC-Rio. Aprovada pela Comissão Examinadora abaixo assinada.
\end{abstract}

\author{
Prof. Henrique Estrada Rodrigues \\ Orientador \\ Departamento de História - PUC-Rio
}

Prof ${ }^{a}$ Adriane Aparecida Vidal Costa

Departamento de História - UFMG

Prof ${ }^{\mathrm{a}}$ Beatriz de Moraes Vieira

Departamento de História - UERJ

Prof ${ }^{a}$ Mônica Herz

Vice-Decana de Pós-Graduação do Centro de Ciências Sociais -PUC-Rio 
Todos os direitos reservados. É proibida a reprodução total ou parcial do trabalho sem autorização do autor, do orientador e da universidade.

\section{Bruna Tavares Camargos}

Graduou-se em História pela Universidade Estadual do Rio de Janeiro (2011). Especialização em Relações Internacionais pelo Ibmec RJ (2014). Se interessa pelo estudo da literatura latino-americana e sua interface com o pensamento crítico e social na América Latina, da crítica da cultura, da teoria da história e das relações entre museu, arte, cidade e território. Atualmente é educadora no Museu de Arte do Rio (MAR), desenvolvendo políticas de acesso e agenciamento local.

Ficha Catalográfica

\section{Camargos, Bruna Tavares}

Mario Vargas Llosa e a Teoria dos "Demônios" : entre obsessões, rebeldia e liberdade / Bruna Tavares Camargos ; orientador: Henrique Estrada Rodrigues. - 2017. $208 \mathrm{f.} ; 30 \mathrm{~cm}$

Dissertação (mestrado)-Pontifícia Universidade Católica do Rio de Janeiro, Departamento de História, 2017.

Inclui bibliografia

1. História - Teses. 2. História Social da Cultura - Teses. 3. Intelectuais engajados. 4. Mario Vargas Llosa. 5. Gabriel García Márquez. 6. Ángel Rama. 7. Crítica literária. I. Rodrigues, Henrique Estrada. II. Pontifícia Universidade Católica do Rio de Janeiro. Departamento de História. III. Título. 


\section{Agradecimentos}

À minha família, pelo carinho e pela compreensão das minhas (im)possibilidades.

Ao meu orientador, Prof. Henrique Estrada Rodrigues, pelas críticas e paciência infinda na leitura das diversas versões que as partes desse trabalho tiveram.

As professoras Adriane A. Vidal Costa e Beatriz de Moraes Vieira pelas orientações no exame de qualificação, leitura crítica e indicações bibliográficas. Agradeço o apoio do Programa de Pós-graduação do Departamento de História da PUC-Rio, durante a realização do trabalho.

A minha gratidão aos companheiros de mestrado, em especial a Marina Marcucci, Michelle Alves, Julia Manacorda e Vaneza de Azevedo, que na angústia da qualificação me deram suporte emocional, acolhendo-me de forma afetuosa.

Aos educadores do Museu de Arte do Rio, por me mostrar que é possível uma relação de trabalho mais humanizada, que resistir é preciso, sobretudo num cenário de retrocesso político e violação de direitos. À Janaina Melo, Gleyce Kelly Heitor, Amanda Campos, Karen Aquini, Maria Clara Boing, Leonardo Siqueira e Douglas Ponso, por compartilharmos um mundo cuja substancia se encontra no cuido e respeito que podemos, e devemos ter com a vida. Obrigada pela torcida!

A todos os meus amigos que sempre me apoiaram, entenderam minhas ausências e ouviram minhas "lamentações". À Pâmela Cezário que não desistiu de mim e me proporcionou momentos de "fuga" do imenso labirinto de uma pesquisa. A meu companheiro Patrick Medeiros Bettini, sempre generoso, compreensivo e amoroso, que dividiu comigo as incertezas e alegrias, dando-me apoio cotidiano para que esse trabalho pudesse existir. 


\section{Resumo}

Camargos, Bruna Tavares; Rodrigues, Henrique Estrada. Mario Vargas Llosa e a Teoria dos 'Demônios': Entre Obsessões, Rebeldia e Liberdade. Rio de Janeiro, 2017. 208p. Dissertação de Mestrado Departamento de História, Pontifícia Universidade Católica do Rio de Janeiro.

O presente estudo analisa a formação do pensamento crítico literário do escritor peruano Mario Vargas Llosa ao longo dos anos sessenta e setenta. Neste período, marcado pela experiência revolucionária cubana e a expansão internacional da narrativa latino-americana, pensar a literatura era também pensar os modos de existência político-social no continente. Dessa forma, este trabalho divide-se em quatro momentos distintos e relacionais tendo como objeto de investigação, principal, a formulação da teoria dos "demônios" de Vargas Llosa desenvolvida de modo sistemático em seu livro Gabriel García Márquez: historia de un deicidio (1971). Inicialmente, busca-se a compreensão da conformação do pensamento de Vargas Llosa sobre o papel do intelectual e a função políticosocial da literatura no contexto dos anos sessenta, assim como a historicidade de seu ensaio sobre a obra do escritor colombiano García Márquez. Num segundo momento, analisamos o conteúdo da teoria dos "demônios" estabelecendo os diálogos com os pensamentos e conceitos de outros intelectuais, tais como JeanPaul Sartre e Sigmund Freud. Depois, segue-se a análise das primeiras recepções críticas da interpretação de Vargas Llosa sobre a vocação do romancista e a natureza da literatura, compreendendo que os posicionamentos políticos do escritor peruano adquirem fundamental relevância nesse processo. Finalmente, aborda-se a polêmica entre Ángel Rama e Vargas Llosa, em 1972, na qual analisamos através dos repertórios e conceitos requeridos no debate os tensionamentos e noções de modernização político-cultural no discurso de ambos os polemistas.

\section{Palavras-chave}

Intelectuais engajados; Mario Vargas Llosa; teoria dos demônios; cultura latino-americana; crítica literária. 


\section{Abstract}

Camargos, Bruna Tavares; Rodrigues, Henrique Estrada (Advisor). Mario Vargas Llosa and the Theory of 'Demônios': Between Obsessions, Rebellion and Freedom. Rio de Janeiro, 2017. 208p. Dissertação de Mestrado - Departamento de História, Pontifícia Universidade Católica do Rio de Janeiro.

The present study analyzes the literary critical thinking formation of the Peruvian writer Mario Vargas Llosa throughout the sixties and seventies. In this period, marked by Cuban revolutionary experience and the international expansion of Latin American narrative, to think literature was also to think about the ways of political-social existence on the continent. Thus, this work is divided into four distinct and relational moments having as main research object the formulation of the theory of the "demons" of Vargas Llosa systematically developed in his book Gabriel García Márquez: historia de un deicidio (1971). Firstly, an attempt is made to understand Vargas Llosa's understanding of the role of the intellectual and the political-social function of literature in the context of the 1960s, as well as the historicity of his essay on the work of Colombian writer García Márquez. In a second moment, we analyze the content of the theory of "demons" by establishing dialogues with the thoughts and concepts of other intellectuals, such as Jean-Paul Sartre and Sigmund Freud. Then follows the analysis of the first critical receptions of Vargas Llosa's interpretation of the novelist's vocation and the nature of the literature, understanding that the political positions of the Peruvian writer acquire fundamental relevance in this process. Finally, we discuss the polemic between Ángel Rama and Vargas Llosa in 1972, in which we analyzed through the repertoires and concepts required in the debate the tensions and notions of political-cultural modernization in the discourse of both polemicists.

\section{Keywords}

Engaged intellectuals; Mario Vargas Llosa; theory of demons; Latin American culture; literature critics. 


\section{Sumário}

1 . Introdução

2. A invenção de um lugar: América Latina, Intelectuais, Literatura

e Política

16

2.1. O escritor como intelectual 23

2.2. Redes de sociabilidade e a "nova narrativa latino-americana" 41

2.3. "América Latina" como "Linguagem" 55

2.4. Macondo "nuestra América" 77

3. Teoria dos "demônios" e seus "obsessores" 86

3.1. Diálogos com Sartre: os "demônios" e a liberdade como questão 91

3.2. O discurso do inconsciente: Freud e Vargas Llosa 106

3.3. Em busca do Romance Total 116

4. Vargas Llosa, antagonismos e dissidências

129

4.1. Rebeldia ou Revolução? Julio Cortázar, Vargas Llosa e Óscar Collazos

4.2. O "caso Padilla" e debate o debate intelectual 138

5. A Polêmica Ángel Rama e Mario Vargas Llosa: pensamento crítico e modernização literária

5.1. Entre o regresso dos "demônios" e o escritor como produtor 151

5.2. Uma arma chamada romance 177

6. Conclusão 201

7. Referências bibliográficas 204 


\section{1. \\ Introdução}

Mario Vargas Llosa foi um dos expoentes mais notórios da internacionalização da literatura latino-americana, contribuindo através de seus romances com a renovação da linguagem literária do continente. Nascido em Arequipa, no Peru, em 28 de março de 1936, o escritor peruano foi o romancista mais jovem do que seria denominado como "nova literatura latino-americana" ou "boom narrativo". Circunscrito temporalmente entre a década de sessenta e início dos anos setenta, o fenômeno literário revela o desenvolvimento de um sistema em que se articulam diversos fatores, tais como: a ampliação do mercado consumidor, as políticas culturais e os projetos intelectuais. Nesses projetos, se acentuava o compromisso com a América Latina, desde sua modernização estética, promovendo uma revisão historiográfica e novos modelos literários, aos fatores políticos que tangenciam as perspectivas emancipatórias para os países latino-americanos. Ao analisar o período entre as décadas de sessenta e setenta, a professora e pesquisadora chilena Ana Pizarro nomeou como modernidade tardia o processo de afirmação identitária que fez emergir um impulso criativo de fortes proporções em diversas ordens, articulando o projeto de descolonização, o auge das lutas de massas na América Latina, os feminismos e as reivindicações afroamericanas, ao plano histórico político. Questões que originaram uma reflexão profunda tanto nas ciências sociais como na teoria da cultura ${ }^{1}$.

O pensamento crítico de Vargas Llosa é forjado num contexto em que as meditações literárias estão fortemente arraigadas ao universo político e ideológico do pós-Segunda Guerra Mundial. Em seus artigos e ensaios, seja de crítica literária ou de opiniões acerca da política, aparece de modo progressivo uma subjetividade crítica que articula dimensões como obsessões, rebeldia e liberdade. Neste trabalho analisamos a trajetória da teoria dos "demônios" no pensamento crítico de Vargas Llosa, desenvolvida de modo sistemático no livro Gabriel García Márquez: historia de un deicidio (1971), originalmente escrito como tese de doutorado. A escolha pela investigação de tal teoria deve-se ao fato de nela

1 PIZARRO, Ana. El sur y los trópicos. Ensayos de cultura latinoamericana. Alicante: Universidad de Alicante, 2004, p.41-42. 
encontrarmos as dimensões fundamentais da crença do escritor peruano a respeito da função político-social da literatura e da vocação do escritor.

Em nossa análise consideramos a perspectiva de Vargas Llosa sobre a literatura como um processo. Embora seus posicionamentos ideológicos tenham se modificado, indo do apoio ao socialismo e à Revolução Cubana à adesão ao neoliberalismo - o que impactou nos sentidos de suas colocações e na recepção crítica de suas ideias políticas e literárias -, a compreensão de Vargas Llosa a respeito do papel da literatura e do escritor se mantiveram ao longo do tempo, com algumas variações dos termos empregados. No prólogo de A cultura do romance (2009), organizado por Franco Moretti, Vargas Llosa declara que considera a literatura, "além de uma das ocupações mais estimulantes e fecundas da alma humana, uma atividade insubstituível para a formação do cidadão numa sociedade moderna e democrática, de indivíduos livres [...]" 2. Ao se questionar se seria possível pensar o mundo moderno sem o romance, o escritor peruano justifica a necessidade de existência do gênero ao concluir que este teria dois benefícios primordiais para a sociedade: o primeiro atende ao plano da linguagem, com o desenvolvimento de um campo expressivo de maior relevância e densidade. O segundo, é que "sem ele, o espírito crítico, motor da mudança histórica e o melhor defensor da liberdade de que dispõem os povos, sofreria um empobrecimento irreparável". Para o autor, "uma boa literatura é a que põe radicalmente em discussão o mundo em que vivemos" ${ }^{3}$. Como se evidencia ao longo desta investigação trata-se de uma percepção literária desenvolvida ao longo das décadas de sessenta e setenta.

A pesquisa foi realizada por meio da análise de artigos, ensaios, entrevistas, memórias e romances, que trazem a visão do escritor peruano sobre o âmbito cultural da época e contribuições importantes para a reflexão sobre a situação política latino-americana, percebida de modo conjunto em sua inserção nos debates político-culturais. O tema está delimitado entre as décadas de sessenta e setenta compreendidas como uma mesma "época", pois, assim como sustenta Claudia Gilman em Entre la pluma y el fusil (2003), “ a caracterização do período é a mesma: o intenso interesse pela política e a convicção de que uma

\footnotetext{
${ }^{2}$ VARGAS LLOSA, Mario. “É possível pensar o mundo sem o romance?”. In: MORETTI, Franco (org.). A cultura do romance. São Paulo: Cosac Naify, 2009, p.20.

${ }^{3}$ Ibidem, p.26
} 
transformação radical, em todos as ordens, era iminente" ${ }^{4}$. Alguns marcos do período orientam a divisão dos capítulos, a saber, a Revolução Cubana e os desdobramentos nos debates intelectuais; a publicação do livro Gabriel García Márquez: historia de un deicidio (1971); a prisão do poeta Heberto Padilla em Cuba, em 1971, e com ela as tensões políticas que geraram quadros de dissidência dos intelectuais em torno de Cuba; e, a polêmica entre Vargas Llosa e Ángel Rama, em 1972, a respeito do livro do escritor peruano sobre a obra de García Márquez, principalmente, em torno da teoria dos "demônios". Nestes acontecimentos, Vargas Llosa protagoniza uma série de debates e relações que dizem respeito diretamente às formas como o escritor percebe a modernização cultural na América Latina e o mundo à sua volta. Este trabalho está divido em quatro capítulos, cada qual de forma relacional e complementar, que corroboram com o que poderíamos chamar de um conhecimento progressivo do que podemos saber hoje sobre a história de um livro.

Nos anos sessenta, a experiência revolucionária cubana impactou diretamente o campo cultural, correlacionando o conhecimento da América Latina, a literatura e a política. Um cenário que levou muitos escritores a reforçar a crença no poder transformador da literatura e no compromisso intelectual com o "despertar" de uma consciência crítica. Por um lado, a comunidade de intelectuais, literatos, críticos literários e poetas latino-americanos, passou a se reunir em torno de Cuba como programa político comum, reforçando a convicção de que o socialismo era o caminho de superação do subdesenvolvimento e das heranças coloniais. Por outro, o governo revolucionário cubano possibilitou a criação de espaços comuns, alimentando e institucionalizando a rede intelectual latino-americana que se formava em torno de Cuba, com suas instituições e atividades político-culturais.

Durante os anos sessenta e setenta, as intervenções em revistas, jornais, reuniões, encontros, conferências, correspondências e participação em conselhos editorias, promoviam a circulação dos discursos e sedimentava uma rede de sociabilidade que refletia sobre o papel do intelectual, a integração e o conhecimento da América Latina. Como mostramos no capítulo I, Vargas Llosa participou ativamente dos debates intelectuais latino-americanos dessa época,

${ }^{4}$ GILMAN, Claudia. Entre la pluma y el fusil: debate y dilemas del escritor revolucionário en América Latina. Buenos Aires: Siglo XXI, 2003, p. 39. 
forjando seu ideário a partir dos acontecimentos político-sociais e culturais. Além disso, a experiência do exílio marcou profundamente sua interpretação sobre a América Latina, o papel do intelectual e a função da literatura. Grande parte dos artigos, ensaios e cartas do escritor peruano em torno destas questões estão reunidos no livro Contra vento e maré (1985). No capítulo I, analisamos a conversão do escritor em intelectual; o papel da rede de sociabilidade formada por intelectuais do boom e os significados que o fenômeno adquire para distintos agentes, com especial atenção à promoção do livro Cien años de soledad (1967), de García Márquez, como sintoma da existência de um mercado profissional e a efetividade do campo intelectual. Nesse sentido, recuperamos a historicidade do livro Gabriel García Márquez: historia de un deicidio (1971), como uma experiência material da sociabilidade existente entre Vargas Llosa e García Márquez, que pode ser estendida a outros escritores do boom. Com efeito, as diversas interações da comunidade intelectual latino-americana produziram um arquétipo da cultura do continente, baseada em sua literatura. Assim, a narrativa de Cien años de soledad e a cidade imaginária de Macondo, foram incorporadas ao mapa da literatura ocidental como chave interpretativa da história latinoamericana, representando naquele momento, ainda que idilicamente, o desejo de unidade da América Latina.

No capítulo II, analisamos o conteúdo da teoria dos "demônios" de modo processual no pensamento de Vargas Llosa, com especial atenção ao conteúdo do livro Gabriel García Márquez: historia de un deicidio, estabelecendo os diálogos - entendam-se conflitos e convergências - com os pensamentos e conceitos de Jean Paul-Sartre e Sigmund Freud. Ambos são considerados pelo escritor peruano como referência imagética de suas análises. Inicialmente, recuperamos a relação de Vargas Llosa com o pensamento do filósofo francês com o intuito de evidenciar a construção de suas ideias sobre a literatura, com foco principal no livro de Sartre Que é literatura (1947) e a noção de liberdade, aproximando-os da formulação da teoria dos "demônios". Em seguida, analisamos as possíveis relações da teoria dos "demônios" com a psicanálise de Freud, enfocando a noção de inconsciente descrita na análise freudiana em Escritores criativos e devaneio (1907-1908). Finalizamos o capítulo, mostrando os vocabulários empregados por Vargas Llosa na análise de Cien años de soledad (1967), principalmente na elaboração da noção de romance total. 
Em meados da década de sessenta, a dinâmica do cenário político e cultural na América Latina sofreu uma série de alterações. As utopias e esperanças de uma revolução socialista a nível continental começaram a enfraquecer-se diante da crise econômica enfrentada por Cuba e a burocratização do campo cultural. Neste cenário, começam a aparecer às primeiras divergências da comunidade intelectual de esquerda em torno da Revolução Cubana, o que provocou uma série de polêmicas, chegando ao extremo da ruptura da rede intelectual. Questões que avançaram sobre o modo pelo qual estes intelectuais encaravam o processo de expansão e internacionalização do romance latino-americano, sobretudo o que se compreendeu como implicações do boom.

No capítulo III, mostramos os posicionamentos de Vargas Llosa diante dos dilemas enfrentados pela comunidade intelectual de esquerda e sua ruptura com a Revolução Cubana e o socialismo, assim como a recepção crítica de suas ideias políticas e literárias. Na época da publicação do ensaio Gabriel García Márquez: historia de un deicidio (1971), o escritor peruano esteve inserido em duas polêmicas que ocorreram numa linha temporal muito próxima. A primeira ocorreu em 1969, envolvendo Vargas Llosa, Óscar Collazos e Julio Cortázar, cuja discussão girou em torno do conceito de realidade na literatura, do engajamento do escritor e seu comprometimento com as causas político-sociais na América Latina. Os textos referentes ao debate estão reunidos no livro Literatura en la revolución y revolución en la literatura (1970). Consideramos este como o primeiro debate acerca da teoria dos "demônios" de Vargas Llosa. A segunda polêmica está centrada nas discussões em torno do papel do intelectual na e para a Revolução. Os antagonismos adquirem contornos dramáticos com a prisão do poeta Heberto Padilla e sua autocrítica, em 1971, gerando quadros de dissidências.

No capítulo IV, analisamos a polêmica relativa à teoria dos "demônios" entre Ángel Rama e Vargas Llosa, nas páginas do semanário Marcha, em 1972. Os artigos que compõem o debate estão reunidos no livro García Márquez y la problemática de la novela (1973). Através dos repertórios e conceitos mobilizados pelos dois polemistas, buscamos compreender as distintas leituras sobre a literatura e a função do escritor. Ademais, o debate nos permite observar as urgências teórico-metodológicas no exercício da crítica literária da época. Dessa forma, procuramos assinalar as concepções de Ángel Rama e Vargas Llosa no que se refere à modernização literária e cultural da América Latina. 
O tema que nos propomos a analisar é norteado pelas discussões sobre a história intelectual. De acordo com o historiador Jorge Myers, aquilo que hoje costumamos chamar de história intelectual delimita um campo de fronteiras frouxas, permeáveis, incertas, em cujo interior entrecruzam-se e sobrepõem-se numerosas correntes disciplinares. Numa formulação sucinta, o autor enfatiza que a história intelectual consiste em uma exploração da produção douta realizada pelas elites letradas do passado, enfocada a partir de uma perspectiva que considera a própria condição de inteligibilidade histórica dessa produção como derivada de sua reinserção em um contexto social e cultural, simbólico e material $^{5}$. Essas elites não estão definidas a priori por nenhum pertencimento de classe ou de estamento, o que inclui, na terminologia de Antonio Gramsci, qualquer "intelectual orgânico", ou grupo de "intelectuais orgânicos" que, por seu nível de auto concentração de recursos simbólicos, esteja em condições de desenvolver um discurso que interpele um âmbito mais extenso que o próprio entorno imediato, sendo a decisão acerca da presença ou não dessas condições uma das tarefas a ser resolvida pelo pesquisador dedicado à história intelectual ${ }^{6}$.

A historicidade da história intelectual tem raiz em seu projeto de apreender as ideias, os discursos, o pensamento, as ideologias como artefatos históricos cuja condição de possibilidade de serem portadores de significado exige a presença de um conjunto de interlocutores cuja identidade sócio-histórica possa ser empiricamente reconhecida. Assim, procuramos articular o desenvolvimento do pensamento crítico de Vargas Llosa e sua teoria dos "demônios" aos seus interlocutores, sejam aqueles que o escritor identifica como "influência", sejam aqueles em que o embate ideológico nos permite compreender a situação políticocultural da época. Além disso, o fato propriamente da "produção" é um dos focos de nossa investigação. De acordo com Myers, a produção intelectual está inserida em um sistema coletivo, social, que excede aos indivíduos e que não só marca limites à sua possibilidade de articular uma expressão individual, "original”, como incide sobre as próprias condições de inteligibilidade do produto douto que

\footnotetext{
${ }^{5} \mathrm{O}$ termo "douto", utilizado por Myers, refere-se à necessidade de uma linguagem elaborada, complexa, que remeta a uma tradição, mas não só a uma linguagem expressa por signos alfabéticos ou caracteres pictográficos. MYERS, Jorge. "Músicas distantes. Algumas notas sobre a história intelectual hoje: horizontes velhos e novos, perspectivas que se abrem". In: SÁ, Maria Elisa Noronha de (org.). História intelectual latino-americana: itinerários, debates e perspectivas. Rio de Janeiro: Ed. PUC-Rio, 2016, p.24-25.

${ }^{6}$ Ibidem, p.25.
} 
contribuíram para colocar em circulação. Não existe obra isolada, incomunicável, mesmo quando se proponha como objeto específico analisar uma única obra ${ }^{7}$.

Para reconstruir o sentido do texto, procura-se ressituá-lo dentro do contexto de significação disponível na época em que foi originado. Para Myers, os discursos e as linguagens são matérias coletivas, mas o historiador trabalha com um material que, em algum ponto, implica a presença de seus "veículos humanos, de autores que atuam sobre a tradição, a linguagem, ou o campo, que os modificam ao mesmo tempo em que são por eles modificados, que incidem - em menor ou maior medida - sobre o contexto que os contém com sua obra" ${ }^{8}$.

Os esquemas de sensibilidade e intelecção, mesmo em épocas muito próximas, são para nós, ao menos em parte, estranhos: "o passado é sempre um país estrangeiro cuja língua exige ser estudada e aprendida antes de que aceite liberar toda a sua riqueza de sentidos possíveis" ". Como diria Vilém Flusser, é preciso duvidar. A dúvida pode ser concebida como uma procura de certeza que começa por destruir a certeza autêntica para produzir certeza inautêntica ${ }^{10}$. A dúvida é um estado de espírito polivalente. Dessa forma, as aproximações do sujeito e do objeto são sempre um fato provisório, contingente.

Para a elaboração desta dissertação, além dos textos citados acima, consultamos inúmeros artigos, ensaios e entrevistas de Vargas Llosa, assim como sua autobiografia El pez en el agua (1993). Consultamos também as publicações da revista Casa de las América, Marcha e Mundo Nuevo ${ }^{11}$. No decorrer da pesquisa, os trabalhos que tratam especificamente do debate intelectual latinoamericana foram de fundamental importância. Apoiamo-nos, sobretudo na tese de

\footnotetext{
${ }^{7}$ Ibidem, p.28.

${ }^{8}$ Ibidem, p.31.

${ }^{9}$ Ibidem, p.29.

${ }^{10}$ FLUSSER, Vilém. A dúvida. São Paulo: Annablume, 2011, p.22.

${ }^{11}$ As edições da revista Casa de las Américas consultadas neste trabalho são originárias do acervo particular da Prof. ${ }^{a}$ Dr. ${ }^{\text {a }}$ Adriane A. Vidal Costa, a quem agradeço pela generosidade na partilha destas, e do acervo bibliográfico, sobretudo, de editoras não brasileiras. As edições consultadas do semanário Marcha estão disponíveis em: $\langle$ http://biblioteca.periodicas.edu.uy/collections/show/10 $>$. E, revista Mundo Nuevo está disponível em: <http://periodicas.edu.uy/v2/minisites/mundonuevo/indice-de-numeros.htm>.
} 
Adriane A. Vidal Costa, Intelectuais, Política e Literatura na América Latina: o debate sobre revolução e socialismo em Cortázar, García Márquez e Vargas Llosa (1958-2005); e Claudia Gilman, Entre la pluma y el fusil: debate y dilemas del escritor revolucionário en América Latina (2003).

As análises que abordam o desenvolvimento literário da época, principalmente as questões relativas à "nova literatura latino-americana" ou "boom narrativo", também foram de extrema relevância. Entre as obras consultadas, podemos citar o livro América Latina em sua literatura (1972), encomendado pela Unesco e coordenado por César Fernández Moreno; El boom en perspectiva, de Ángel Rama; Historia personal del boom (1983), de José Donoso; e, El sur y los trópicos. Ensayos de cultura latino-americana (2004), de Ana Pizarro.

Por fim, sobre Jean-Paul Sartre, gostaria de destacar a tese de Thana Mara Souza, Da estética à ética: uma análise compreensiva das obras literárias de Sartre e Malraux; e o artigo de Franklin Leopoldo e Silva, Literatura $e$ experiência histórica em Sartre: o engajamento. Sobre Ángel Rama, destaco o livro Transculturação narrativa: seu percurso na obra crítica de Ángel Rama (2007), de Roseli B. Cunha; e o livro organizado por Flavio Aguiar e Joana Rodrigues, Ángel Rama: um transculturador do futuro (2013). 


\title{
2.
}

\section{A invenção de um lugar: América Latina, Intelectuais, Literatura e Política}

\begin{abstract}
Ao pão, o pão, ao vinho, o vinho: ou o socialismo decide suprimir para sempre essa faculdade humana que é a criação artística e eliminar de uma vez por todas esse espécime social que se chama escritor, ou admite a literatura em seu seio e, neste caso, não tem mais remédio que aceitar uma perpétua torrente de ironias, sátiras e críticas que irão do adjetivo ao substantivo, do passageiro ao permanente, das superestruturas à estrutura, do vértice à base da pirâmide social. As coisas são assim e não há escapatória: não há criação artística sem inconformismo e rebelião. A razão de ser da literatura é o protesto, a contradição e a crítica. O escritor tem sido, é e continuará sendo um descontente.
\end{abstract}

Mario Vargas Llosa

O trecho acima foi retirado do artigo "Una insurrección permanente", do escritor peruano Mario Vargas Llosa, publicado em 1966, no semanário Marcha. Neste texto, o autor critica o julgamento e a condenação dos escritores russos Andrei Siniavski e Yuli Daniel pelo governo soviético, acusados de "agitação e propaganda antissoviética"1. De início, Vargas Llosa assume um tom manifesto e uma fala coletiva, expressa na frase: "Nós, escritores que acreditamos no socialismo e que nos consideramos amigos da URSS, devemos ser os primeiros a protestar [...]"2 . Tendo como ponto de partida o caso Siniavski-Daniel, Vargas Llosa teceu algumas considerações sobre o papel do escritor nas sociedades socialistas. A seu ver, o escritor deveria ter como missão a luta em prol de uma sociedade socialista que possibilitasse cortar todas as mordaças e vendas que, ao longo da história, foram impostas a ele. Ao concluir o artigo, Vargas Llosa ressalta que, no socialismo que ambicionava, deveriam ser suprimidos não apenas a exploração do homem pelo homem, mas também “os últimos obstáculos para que o escritor" possa "livremente escrever o que lhe dê vontade, começando, naturalmente, por sua hostilidade ao próprio socialismo"3. A argumentação desenvolvida por Vargas Llosa evidencia a intensa relação entre política e literatura na América Latina dos anos sessenta e setenta, impactando diretamente

\footnotetext{
${ }^{1}$ Em 1965, os dois escritores russos foram presos e condenados por publicarem livros no exterior que expressavam discordâncias com o regime soviético. A condenação dos escritores foi sucedida por uma série de protestos de jornais, personalidades e partidos comunistas europeus. Sobre o caso Siniavski-Daniel, ver: PATULA, Jan. Europa del Este: del stalinismo a la democracia. México: Siglo XXI, 1993, 396p.

2 VARGAS LLOSA, Mario. [1966] "Uma insurreição permanente”. In: Contra vento e maré. Rio de Janeiro: Francisco Alves, 1985, p. 86.

${ }^{3}$ Ibidem, p. 89.
} 
a compreensão sobre o papel da literatura, o conceito de América Latina e a práxis intelectual deste período.

Nos anos sessenta, a América Latina está maioritariamente inserida no âmbito internacional - ainda que de modo periférico -, experimentando os efeitos e dinâmicas do que Ana Pizarro nomeou como modernidade tardia. Segundo a autora, a modernidade periférica tardia latino-americana foi presidida por um ethos alternativo em relação à perspectiva imperante nos anos cinquenta, quando os imaginários sociais estavam impregnados pela visão imperial norte-americana ${ }^{4}$. Neste contexto, foram as experiências de um mundo polarizado do pós-guerra, da complexidade dos fluxos culturais que se entrecruzavam, adquirindo caráter residual ou emergente, que forjaram a espessura de uma nova geografia cultural no continente e com elas as formas de pensamento e projetos intelectuais. De acordo com Pizarro, a

[...] América Latina tem no período um desenvolvimento histórico e cultural próprio, cujo perfil incorpora elementos tanto deste espaço internacional como do regional, em diferente dinâmica e com específicas relações. Estas não são somente econômicas ou políticas, senão também sociais, de constituição dos imaginários coletivos, da comunicação, da conformação geral do mundo simbólico. É um momento que diríamos, com a linguagem de hoje, que se estabelecem redes globalizadas, porém, a partir dos movimentos não hegemônicos: os sociais na América Latina, os de descolonização na África, os anti-neocoloniais na Ásia como no caso do Vietnã -, ou o Movimento pelos Direitos Civis nos Estados Unidos. $^{5}$

Sob o signo do "novo", este é um período cuja expressão dos imaginários sociais encontra-se ligada a uma mudança de sensibilidade, à emergência de diferentes estruturas, conteúdos e atores que preconizavam novas formas de enunciação e horizontes de futuro de um projeto por cumprir-se. Para Ana Pizarro, foi a Revolução Cubana o marco inaugural deste ethos alternativo da modernidade ao sul do continente. Diversas análises apontam a Revolução

\footnotetext{
${ }^{4}$ Os Estados Unidos recém-saídos da Segunda Guerra Mundial, com uma aura de triunfo, se consolidam como uma superpotência, irradiando, sobretudo, através do cinema Hollywoodiano - o grande aparato midiático desse momento - uma perspectiva da vida profundamente inserida no status quo, com uma visão da história fortemente conservadora. Na América Latina o projeto imperialista aparecia claramente nas políticas do "big stick", na invasão dos Estados Unidos a Nicarágua e a República Dominicana e na Emenda Platt, aportando o território latino-americano a um lugar de subordinação. Perspectiva que muda radicalmente com o início da Revolução Cubana no continente. (PIZARRO, Ana. El sur y los trópicos. Ensayos de cultura latinoamericana. Alicante: Universidad de Alicante, 2004, p.30-31).

${ }^{5}$ Ibidem, p.30-31.
} 
Cubana como um paradigma fundamental para se compreender a comunidade intelectual da época 6 .

Como ressalta Adriane Vidal Costa, a noção de socialismo na América Latina do século XX possuía um conteúdo amplo e diverso. Numerosos partidos e grupos progressistas, reformistas, nacionalistas e de esquerda democrática proclamavam-se socialistas, defendendo, em linhas gerais, uma modernização de corte nacionalista, orientada pelos paradigmas de industrialização, de urbanização e de racionalização da vida cotidiana. Para a autora, ao romper, até certo ponto, com o esquema formal de classes-partidos e alianças de classes, a Revolução Cubana assinalou uma nova época política na América Latina, que estipulava o compromisso político-social de grande parte das esquerdas ${ }^{7}$.

Inicialmente um fenômeno de natureza político territorial, a Revolução Cubana acabou por ampliar sua influência, impactando diferentes regiões. De acordo com Saúl Sosnowski, diante das práticas e utopias revolucionárias, foi inevitável uma alta e explícita ideologização do campo literário. Um cenário propício que levou muitos escritores a reforçar a crença no poder transformador da literatura ${ }^{8}$. O socialismo significava para os intelectuais de esquerda a possibilidade de modernização da América Latina, sendo percebido como um caminho de superação da herança sociocultural deixada pelo colonialismo, e, ao mesmo tempo, de criação de uma nova consciência coletiva, de caráter identitário.

\footnotetext{
${ }^{6}$ Dentre as quais podemos citar: Entre la pluma y el fusil: debate y dilemas del escritor revolucionário en América Latina (2003), de Claudia Gilman; La 'nueva' novela hispanoamericana: ruptura y 'nueva' tradición (1995), de Saúl Sosnowski; Intelectuais, Política e Literatura na América Latina: o debate sobre revolução e socialismo em Cortázar, García Márquez e Vargas Llosa (1958-2005) (2009), de Adriane A. Vidal Costa.

${ }^{7}$ Entre os marcos do desenvolvimento do socialismo na América Latina, Costa assinala a expansão da Segunda Internacional, do anarquismo e do sindicalismo de matriz soreliana; a expansão da Terceira Internacional e a fundação dos partidos comunistas; a contribuição teórica de José Carlos Mariátegui; a insurreição liderada por Farabundo Martí em El Salvador; o desenvolvimento do castrismo e do guevarismo; a experiência socialista no Chile e a Frente Sandinista de Libertação (FSLN) na Nicarágua. (COSTA, Adriane A. Vidal. Intelectuais, Política e Literatura na América Latina: o debate sobre revolução e socialismo em Cortázar, García Márquez e Vargas Llosa (1958-2005). 413 f. Tese (Doutorado em História) - Programa de Pós-Graduação do Departamento de História da Faculdade de Filosofia e Ciências Humanas da Universidade Federal de Minas Gerais. 2009, p. 41).

${ }^{8}$ SOSNOWSKI, Saul. "La 'nueva' novela hispanoamericana: ruptura y 'nueva' tradición”. In: PIZARRO, Ana (org.). América Latina: palavra, literatura e cultura. $3^{\circ}$ vol. São Paulo: Memorial; Campinas: UNICAMP, 1995, p. 395. Entre os intelectuais que apoiaram inicialmente a revolução cubana estavam os latino-americanos como Alejo Carpentier, José Lezama Lima, Roberto Fernández Retamar, Guillermo Cabrera Infante, Mario Vargas Llosa, Octavio Paz, Gabriel García Márquez, Ángel Rama, Marta Traba, Carlos Fuentes e Julio Cortázar; além de escritores europeus como Jean-Paul Sartre, Herbert Marcuse, Hans Magnus Enzensberger. (COSTA, Adriane A. Vidal, op. cit., p.44-45).
} 
Desde o início da Revolução Cubana foram criados vários espaços de difusão cultural, como revistas e editoras governamentais e independentes, teatros, bibliotecas, cinemas etc., além de instituições estatais responsáveis por estabelecer relações culturais com a América Latina, como é o caso da Casa de las Américas (1959), do Instituto Cubano del Arte y Industria Cinematográficas - ICAIC (1959), da editora estatal Imprenta Nacional (1960), do Consejo Nacional de Cultura - CNC (1961), e da Unión de Escritores y Artistas de Cuba - UNEAC $(1961)^{9}$.

No marco internacional, Paris se configura como o núcleo de religação que organiza dimensões importantes da arte continental, como ponto de referência que absorve os criadores e irradia formas de sua própria modernização sobre a América Latina ${ }^{10}$. De acordo com Vargas Llosa, grande parte dos escritores mais importantes da América Latina havia vivido, vivia ou passava por Paris, e os que não o faziam, de uma maneira ou de outra, eram descobertos, traduzidos e promovidos na França, "e por conta disso a América Latina reconhecia e começava a ler seus próprios escritores"11. Cidades como Madrid e Barcelona também foram centrais neste processo, uma vez que as editoras espanholas promoveram um intercâmbio transatlântico dos escritores, durante a década de sessenta.

$\mathrm{Na}$ trajetória intelectual de Vargas Llosa, as cidades de Paris, Madrid e Barcelona foram de fundamental importância ${ }^{12}$. Em 1958, após concluir sua licenciatura na Universidad Nacional Mayor de San Marcos, Vargas Llosa

\footnotetext{
${ }^{9}$ Sobre a política cultural em Cuba, ver: VILLAÇA, Mariana Martins. O Instituto del Arte e Industria Cinematográficos (ICAIC) e a política cultural em Cuba (1959-1991). 434 f. 2 v. Tese. FFLCH (Departamento de História), USP, São Paulo, 2006.

${ }^{10}$ Conforme Costa, desde as vanguardas latino-americanas dos anos 1920 e 1930, Paris despertava o interesse dos escritores, pois, dentre outras coisas, a tradução para o francês era uma instância de internacionalização do escritor latino-americano. Em Paris, Miguel Ángel Asturias foi embaixador do governo de Méndez Montenegro; Pablo Neruda foi embaixador do Chile durante o governo Allende; o cubano Alejo Carpentier viveu e morreu em Paris como representante do governo castrista; García Márquez redigiu a primeira versão de El coronel no tiene quien le escriba; Carlos Fuentes, Jorge Edwards, Manuel Scorza, José Donoso, Severo Sarduy, Saúl Yurkievich, Osvaldo Soriano, entre outros, tiveram passagens curtas ou longas pela capital francesa em algum momento de suas vidas. (COSTA, Adriane A. Vidal, op. cit., p.163).

${ }^{11}$ VARGAS LLOSA, Mario [2005]. Dicionário Amoroso da América Latina. Rio de Janeiro: Ediouro, 2006, p. 07.

${ }^{12}$ Vargas Llosa escreveu seu primeiro romance, La ciudad y los perros, em Paris, publicando-o em Barcelona, em 1963, após ter recebido o Prêmio Biblioteca Breve, em 1962, promovido pela editora Seix Barral. Logo após a publicação do romance, o escritor peruano recebeu o Prêmio de la Crítica Española, concedido pela Asociación Española de Críticos às melhores obras literárias publicadas na Espanha. (OVIEDO, Jose Miguel. Mario Vargas Llosa: la invención de una realidad. Barcelona: Seix Barral. 1982, p.22).
} 
recebeu uma bolsa de estudos para fazer doutorado em Letras na Universidad Complutense de Madrid, iniciando sua vida de "autoexílio" na Europa, que durou cerca de dezesseis anos, com breves estadias no Peru. Neste período, viveu entre Madrid e Paris, onde ministrou aulas de espanhol e trabalhou no sistema de Rádio e Televisão Francesa. Foi em Paris que Vargas Llosa recebeu a notícia da Revolução Cubana, acontecimento que, então, marcaria significativamente sua carreira como escritor-intelectual.

A primeira viagem de Vargas Llosa a Cuba ocorreu em 1962, como jornalista enviado pelo sistema de Rádio e Televisão Francesa, para cobrir a crise dos mísseis e a invasão da Baía dos Porcos $^{13}$. Ao retornar a Paris, publicou dois artigos no Le Monde, nos quais relatou sua estadia na ilha ${ }^{14}$. No primeiro, "En Cuba, país sitiado” (nov. 1962), narra a reação dos cubanos diante do bloqueio imposto pelos E.U.A e a confiança destes nos líderes revolucionários. No segundo artigo, "Crónica de la revolución" (nov. 1962), Vargas Llosa evidencia suas impressões sobre a Revolução Cubana, depositando grande esperança na revolução e no socialismo, apontando-o como um sistema que poderia promover a justiça social e tirar os países latino-americanos do subdesenvolvimento.

Essa Cuba revolucionária, ao resistir às pressões dos Estados Unidos, passou a representar idealmente toda a América Latina, adquirindo prestígio perante as esquerdas. O processo revolucionário cubano era percebido por muitos intelectuais como um experimento político-social original, e Fidel Castro, após a entrada triunfal em Havana, em 1959, contribuiu com este tipo de percepção ao definir a Revolução Cubana como "nem capitalista, nem comunista", mas "uma revolução própria, com ideologia própria, com razões cubanas e inteiramente americana"15. Ainda que em 1961, após a invasão da Baía dos Porcos, Fidel Castro tenha definido o caráter socialista da Revolução e o alinhamento com a União Soviética, para Vargas Llosa a experiência cubana era uma forma concreta de socialismo, profundamente singular, pois apresentava diferenças marcantes em relação aos países do bloco soviético, o que, a seu ver, poderia ter repercussões importantíssimas no futuro do socialismo mundial. Neste sentido, o escritor

${ }^{13}$ A partir de então viajou várias vezes a Cuba, tornando-se membro do Conselho editorial da revista Casa de las Américas, cargo que ocupou no período de 1965 a 1971, quando este foi dissolvido.

${ }^{14}$ Os artigos estão publicados no livro Contra vento e maré (1985).

${ }^{15}$ COSTA, Adriane A. Vidal, op. cit., p.41-42. 
peruano assinalou o fato de a Revolução Cubana ter sido a única revolução socialista em que o partido foi criado posteriormente à revolução propriamente dita, ou seja, a luta revolucionária no início não envolveu um partido político, mas foi conduzida por um movimento guerrilheiro, o MR26 de julho, com uma ideologia liberal e humanista bastante vaga. Assim, a revolução foi "determinando sua doutrina política e econômica na prática, no próprio exercício do poder", aproximando-se do marxismo-leninismo na medida em que foi intensificado o cerco dos E.U.A ${ }^{16}$.

Em seu testemunho, Vargas Llosa afirmou que não pretendia negar os problemas da Revolução Cubana, pelo contrário, ele percebia através da imprensa, do rádio e das publicações que existia em "Cuba um empenho oficial para doutrinar as massas". As Ediciones Sociales de Moscou circulavam na ilha e, no discurso, todos os dirigentes da Revolução proclamavam-se marxistas ortodoxos. Porém, ainda que o marxismo fosse declarado como filosofia oficial da revolução, isto não impedia, pelo menos naquele momento, "a existência de outras correntes ideológicas" que podiam expressar-se livremente em Cuba. Além disto, em Cuba não havia uma estética oficial na arte e na literatura. Nas livrarias de Havana havia publicações "trotskistas e anarquistas expostas nas vitrinas", não existindo uma "censura destinada a preservar a pureza ideológica das publicações", como ocorria, por exemplo, na União Soviética ${ }^{17}$. Assim, Vargas Llosa declarou:

\begin{abstract}
Enquanto estive em Havana, o Conselho Nacional de Cultura (onde está um dos melhores escritores contemporâneos de língua espanhola, Alejo Carpentier) patrocinava uma retrospectiva do surrealista Wilfredo Lam e uma exposição coletiva de pintores jovens, todos abstracionistas. Nas publicações literárias, rendia-se homenagem a William Faulkner, elogiava-se Saint-John Perse [...] e discutia-se apaixonadamente os romancistas objetivos. A influência de Sartre é inegável em três dos melhores escritores jovens de Cuba: Ambrosio Fornet, Edmundo Desnoes e Jaime Saruski. ${ }^{18}$
\end{abstract}

Em várias ocasiões o escritor peruano expressou seu apoio a Cuba e a outros movimentos guerrilheiros na América Latina, como o Movimiento de Izquierda Revolucionário (MIR) do Peru ${ }^{19}$. Embora considerasse a Revolução Cubana como

\footnotetext{
16 VARGAS LLOSA, Mario. [1962] “Crônica da Revolução”. In: Contra vento e maré. Rio de Janeiro: Francisco Alves, 1985, p.29-34.

${ }^{17}$ Ibidem, p. 30-31.

${ }^{18}$ Ibidem, p. 31-32.

${ }^{19}$ Em 1963, Vargas Llosa publicou uma homenagem ao poeta e líder guerrilheiro Javier Heraud, em razão de sua morte, na qual ressaltou que se ele "resolveu empunhar armas e tornar-se guerrilheiro significava apenas que o Peru chegou a uma situação-limite. Ninguém mais alheio à
} 
o acontecimento histórico mais importante que ocorreu na América Latina depois dos movimentos pela independência no século XIX, o escritor peruano declarava que sua adesão ao socialismo não era de modo algum dogmática. Em uma entrevista concedida a Günter W. Lorenz, em 1969, ele afirmou que a sua admiração e o seu entusiasmo pela Revolução Cubana não o impediam de reconhecer certos aspectos do socialismo que considerava deficientes ou criticáveis, como, por exemplo, a falta de liberdade de expressão. Por isso, ele aspirava que o socialismo (ou os socialistas) na América Latina aproveitasse a experiência histórica e não incorresse nos erros, equívocos e absurdos que o stalinismo cometeu no campo cultural. Vargas Llosa admitiu que a "liberdade de imprensa" e a "oposição política" eram valores de origem burguesa, mas eram "indubitavelmente as melhores armas com que contava um povo para fiscalizar seus governantes e impedir os abusos do poder". Nestas condições, a seu ver, o escritor deveria cumprir uma função de tipo crítico, comprometendo-se com o socialismo e a causa revolucionária, porém sem abandonar seu compromisso com a rebeldia no dia em que o socialismo realmente se impusesse como realidade ${ }^{20}$.

Ao longo de sua trajetória Vargas Llosa encarnou a função do escritorintelectual de tipo crítico, não poupando nenhum movimento ou governo que sob qualquer prescrição utilizasse da violência ou da censura para impor sua visão de mundo, o que gerou inúmeras controvérsias no campo intelectual de esquerda latino-americano, sobretudo entre aqueles que acreditavam que a função do intelectual era o fortalecimento da revolução ${ }^{21}$. Seja como for, sua visão de mundo conforma-se nas articulações entre os problemas gerais do exercício da vocação literária e os grandes problemas político-sociais do momento.

violência do que ele, por temperamento e convicção". (VARGAS LLOSA, Mario. [1963] "Homenagem a Javier Heraud". In: Contra vento e maré. Rio de Janeiro: Francisco Alves, 1985, p.35-37). Em 1965, Vargas Llosa redigiu uma homenagem ao guerrilheiro do MIR Paúl Escobar, que havia sido assassinado num confronto entre o exército peruano e o MIR em Mesa Pelada, ver: VARGAS LLOSA, Mario. [1965] "Numa Aldeia Normanda, Recordando Paúl Escobar". In: Contra vento e maré. Op. cit., p.78-81. Em 1967, em Paris, pronunciou, ao lado de Sartre e Simone de Beauvoir, um discurso no Palais de la Mutualité em defesa dos presos políticos no Peru. Nesse discurso, Vargas Llosa pediu a liberdade do líder guerrilheiro de Cuzco, Hugo Blanco, preso desde 1963. Em agosto de 1968, publicou um artigo, El diário del Che, na revista limenha Caretas, no qual rendeu uma cálida homenagem a Che Guevara, morto na guerrilha boliviana. (COSTA, Adriane A. Vidal, op. cit., p.110).

${ }^{20}$ VARGAS LLOSA, Mario apud LORENZ, Günter W. Diálogo com a América Latina: panorama de uma literatura do futuro. São Paulo: E.P.U, 1973, p. 158-159.

${ }^{21}$ Um exemplo foi a polêmica entre Vargas Llosa, Óscar Collazos e Julio Cortázar, em 1969, a qual analisaremos no capítulo III. 
Neste capítulo mostraremos as articulações e interações do pensamento de Vargas Llosa com o campo intelectual de esquerda latino-americano da época, assim como a historicidade de seu ensaio García Márquez: história de un deicidio (1971). Pois, é precisamente neste período, entre as décadas de sessenta e setenta, que Vargas Llosa ganhou notoriedade tanto por suas ficções como por sua ensaística, forjando suas percepções literárias e políticas num amplo espectro que ia desde a modernização político-cultural às expectativas revolucionárias. Cabe salientar que, ao falarmos de modernização cultural, estamos nos referindo ao surgimento de uma nova dinâmica entre produção artística, público, condições de mercado e consumo, que boa parte da intelectualidade latino-americana assumiu como pauta das discussões.

\section{1.}

\section{O escritor como intelectual}

O que é um intelectual? Qual a função da cultura e, especificamente, da literatura? Estas questões mobilizaram distintos agentes durante a época que se configura nos anos sessenta e setenta, formulando respostas tão amplas quanto seus agenciamentos. Diversas hipóteses foram lançadas ao mundo, não somente por aqueles que ativamente se encontravam imersos no debate suscitado pelas transformações políticas, sociais e culturais da época, como também, de forma ampla, por aqueles que se debruçaram para compreender, mediante a história intelectual, as representações do mundo social produzida por estes.

De acordo com Zygmunt Bauman, em Legisladores e intérpretes: sobre modernidade, pós-modernidade e intelectuais (1987), a palavra intelectual comporta diferentes definições e uma ampla categoria ao longo de sua história, que vai desde os philosophes aos intérpretes. Na América Latina, ao longo dos anos sessenta, há uma encarnação da noção de intelectualidade vinculada aos discursos críticos e dilemas político-sociais da época, configurando um sistema de valores, intervenções e circulação de autores e pensamentos. Neste espectro, a palavra escrita aparece como instrumento característico de intervenção ou identidade intelectual, convergindo para que as noções de escritor e intelectual surgissem como sinônimas. No estudo dedicado às relações entre a literatura e os 
processos revolucionários na América Latina, Claudia Gilman considera a figura do intelectual como interseção inevitável na vinculação política e cultura. Compreensão que implica tanto uma posição em relação à cultura como uma posição em relação ao poder ${ }^{22}$.

A relação entre política e cultura já havia sido alvo das investigações de Ángel Rama durante toda a década de sessenta, e havia de ocupá-lo, de maneira mais ambiciosa, na década seguinte. A expressão máxima dessa questão encontrase na obra póstuma La Ciudad Letrada (1984), na qual o crítico uruguaio investiga o papel transculturador das culturas urbanas, como modo de evidenciar o mapa e a mecânica da cena pública, dos lugares e instituições que organizam a vida cultural, e a diversidade dos papeis operados pelos atores culturais, principalmente os letrados, nos projetos de cidades na América Latina. Talvez um dos maiores aportes, e aquele que nos interessa objetivamente, é a compreensão de Rama do discurso como prática realizada por agentes para responder a demandas socialmente definidas. Uma materialidade da mediação discursiva de produtores e sujeitos destas práxis, com uma série de procedimentos reguladores e práticas subsidiárias em um momento histórico determinado ${ }^{23}$.

O deslocamento das análises do plano ideológico-representacional para as práticas sociais concretas, relacionando literatura, poder e trabalho intelectual, adquiriu substância a partir da renovação teórica produzida pelos debates da história política e intelectual. No bojo destes deslocamentos de perspectiva, sem dúvida, as contribuições de Michel Foucault e a noção de campo intelectual de Pierre Bourdieu corroboraram, em grande medida, na produção de novos marcos teóricos no que compete à história intelectual. Nesse sentido, estudos como os de Claudia Gilman e Adriane Vidal Costa tangenciam a noção de "campo" de Bourdieu nas pesquisas em torno dos discursos intelectuais na América Latina. É através da "dessacralização" das práticas intelectuais que a noção de campo proporciona instrumentos para compreensão das lógicas, relações internas, regras de organização e hierarquia social dentro do campo intelectual. São sistemas nos

\footnotetext{
${ }^{22}$ GILMAN, Claudia. Entre la pluma y el fusil: debate y dilemas del escritor revolucionário en América Latina. Buenos Aires: Siglo XXI, 2003, p 15-16.

${ }^{23}$ Sobre o sistema de pensamento de Ángel Rama, ver: AGUIAR, Flávio; RODRIGUES, Joana (org.). Um transculturador do futuro. Belo Horizonte: Editora UFMG, 2013. 164 p.
} 
quais os produtos culturais, as trajetórias artísticas e as decisões dos produtores adquirem sentido ${ }^{24}$.

Porém, como ressalta Gilman, a noção de campo intelectual parece sugerir uma espécie de "cegueira dos produtores", cujas posições estéticas estariam fortemente limitadas às relações de força dentro do campo intelectual ${ }^{25}$. Do mesmo modo, Costa considera que, até certo ponto, a noção de campo intelectual é determinista ao propor um sujeito que age de acordo com um espaço de forças estruturado, que molda a capacidade de ação e de decisão de quem dele participa. Isso não deixaria espaço para a contingência ou o inesperado, como foi o caso da posição crítica dos intelectuais a respeito dos rumos da Revolução Cubana, por mais que o governo cubano tentasse modular a capacidade de ação e decisão dos intelectuais de esquerda ${ }^{26}$. Para Helenice Rodrigues da Silva, embora o conceito de campo intelectual possa ser aplicado a realidades diversas, este partilha com sistemas culturais mais rígidos que o latino-americano, como é o caso do europeu ocidental ou norte-americano ${ }^{27}$.

Seja como for, os grupos intelectuais se organizam em torno de uma sensibilidade ideológica ou cultural comum, promulgadas a partir de discursos hegemônicos ou por uma percepção crítica do poder, conformando linhas alternativas. Nesse sentido, um dado importante é a adoção do espaço público como "tribuna" a partir da qual estes intelectuais se dirigem à sociedade. Durante os anos sessenta e setenta, estes "espaços públicos" foram, maioritariamente, as revistas político-culturais e as seções de cultura dos periódicos, nas quais escritores e críticos literários se dirigiam a um público recém-ampliado pelo desenvolvimento urbano das grandes capitais latino-americanas. Dentre outras, podemos citar a revista Casa de las Américas (Cuba), Marcha (Uruguai), Ercilla (Chile), Primera Plana (Argentina), Siempre! (México) e Caretas (Peru). Nestes espaços, os escritores encontraram um cenário poderoso de ratificação da prática

\footnotetext{
24 Bourdieu operacionaliza o conceito de campo juntamente com o conceito de habitus, compreendido como um sistema de disposições socialmente adquiridas e constituídas de um grupo de agentes. Costa resume o conceito de habitus como um sistema socialmente constituído de disposições estruturadas (no social) e estruturantes (nas mentes), adquirido nas e pelas experiências práticas (em condições sociais específicas de existência), constantemente orientadas para funções e ações do agir cotidiano. (COSTA, Adriane A. Vidal, op. cit., p.17-18).

${ }^{25}$ GILMAN, Claudia, op. cit., p. 17.

${ }^{26}$ COSTA, Adriane A. Vidal, op. cit., p.18.

27 SILVA, Helenice Rodrigues da. Fragmentos da história intelectual: entre questionamentos e perspectivas. Campinas: Papirus, 2002, p. 120.
} 
intelectual, do compromisso do escritor, de difusão e comunicação discursiva com o público numa dimensão amplificada da palavra pública, ao mesmo tempo em que se sentiam requeridos a pronunciarem-se e a tomar posições sobre os assuntos contemporâneos, dirigindo-se, em última instância, ao que de modo geral se denominava como América Latina.

Uma particularidade conceitual do período que nos propomos a analisar é a condição do discurso crítico do poder proferido pelos intelectuais, que a partir da experiência da Revolução Cubana adotaram ou reafirmaram com maior intensidade posições de esquerda. Segundo Raymond L. Williams, se analisarmos os textos produzidos por vários escritores nesse período, podemos perceber que grande parte da comunidade de escritores, ainda dispersa, passou a se reunir em torno de Cuba como um programa político comum, o que implicava numa convicção do papel do escritor-intelectual como agente de transformação radical da sociedade e numa confiança absoluta no valor da literatura no desenvolvimento da consciência crítica ${ }^{28}$.

Nesse sentido, torna-se emblemático o discurso de Vargas Llosa, " $\mathrm{La}$ literatura és fuego”, proferido em 1967, ao receber o prêmio Rómulo Gallegos, na Venezuela. Neste discurso, após fazer uma análise sobre a situação do escritorintelectual na América Latina, considerando que este sempre fora um terreno hostil, quase sombrio para os criadores, Vargas Llosa afirma que apesar de um clima mais hospitaleiro para a literatura nos últimos anos, a burguesia desejava integrar o escritor, "oficializá-lo, conjurar sua periculosidade, porque a literatura significava inconformismo e rebelião, dado que a razão de ser do escritor era o protesto, a contradição e a crítica" ${ }^{29}$. Para o escritor peruano, a literatura é uma forma de insurreição permanente, na qual o escritor, com seus posicionamentos e escolhas, deveria assumir um compromisso com os projetos de mudança, visando a justiça social e a emancipação do pensamento. Desta forma, Vargas Llosa realizou uma veemente defesa do governo cubano, posicionamento permeado por implicações políticas, principalmente num contexto em que a Venezuela (país anfitrião do prêmio) havia rompido os contatos políticos com a ilha, o que

${ }^{28}$ WILLIAMS, Raymond L. Literatura y política: las coordenadas de la escritura de Mario Vargas Llosa. In: VARGAS LLOSA, Mario. Literatura y política. Madrid: Fondo de Cultura Económica de España, 2003, p.17.

${ }_{29}$ VARGAS LLOSA, Mario. [1967] “A Literatura é fogo". In: Contra vento e maré. Rio de Janeiro: Francisco Alves, 1985, p.134-135. 
provocou violentas críticas nos âmbitos oficiais venezuelanos ${ }^{30}$. As revistas cubanas, por sua vez, comemoraram a provocação de Vargas Llosa. Na revista Unión, o discurso foi reproduzido parcialmente com o título "Vargas Llosa, aguafiesta en Caracas", seguido pelo comentário de que ao final de seu esplêndido discurso, o escritor peruano pontuou que aceitava o prêmio venezuelano porque estimava que este não lhe exigia nem a mais leve sombra de compromisso ideológico, político ou estético ${ }^{31}$.

Como assinala Gilman, os escritores politizados da época tiveram muito presente a compreensão de que sua intervenção nos assuntos públicos não era somente uma possibilidade, senão uma obrigação, confiando em sua potencialidade discursiva como potência de intervenção prática na sociedade ${ }^{32}$. Os intelectuais elaboraram hipóteses de que deviam cumprir um mandato social, como representantes da humanidade, entendida por termos coletivos como: público, nação, classe, povo, continente, Terceiro Mundo, entre outros ${ }^{33}$. A politização das letras e a encarnação do intelectual comprometido, principalmente com os setores mais populares, estiveram tematizados em diferentes textos e encontros, como é o caso do Congresso de Intelectuales de Concepción, realizado no Chile, em 1962, no qual grande parte dos escritores presentes manifestaram sua adesão à causa cubana e uma compreensão do intelectual socialmente responsável $^{34}$. De acordo com Ángel Rama, a reinscrição do homem das letras como intelectual era imperativa se o escritor queria perder "essa deletéria sensação de gratuidade de seu trabalho" 35 .

$\mathrm{Na}$ construção deste lugar da atividade artística e intelectual o pensamento e as atitudes de Jean-Paul Sartre funcionaram como um referente, pelo menos desde meados dos anos cinquenta, embasando teoricamente toda uma discussão acerca

\footnotetext{
${ }^{30}$ Em 1961, durante o governo de Rômulo Bettancourt (1958-1964), de orientação liberal, as relações com Cuba foram cortadas. Ademais, o governo venezuelano apoiou o bloqueio dos E.U.A a Cuba. No governo seguinte, de Raúl Leoni (1964-1967), foram mantidos os tratados de reciprocidade com os Estados Unidos e a política externa da doutrina Bettancourt. (OLIVEIRA, Renata Peixoto de. "Venezuela e os antecedentes de uma Política Externa ativa: petróleo e democracia como elementos da Política Externa do regime de Punto Fijo". Revista do IMEAUNILA (RevIU). Vol. 1, n. 2, 2013, p. 132-140).

${ }^{31}$ GILMAN, Claudia, op. cit., p.75.

${ }^{32}$ Idem.

${ }^{33}$ Ibidem, p.59.

${ }^{34}$ José Donoso afirmou que durante o congresso havia "experimentado pela primeira vez uma repentina e poderosa maré de simpatia por uma causa política, que unificava o continente e a todos os seus escritores." (DONOSO, José. Historia personal del boom. Barcelona: Seix Barral, 1983, p. 36-46).

${ }^{35}$ RAMA, Ángel apud GILMAN, Claudia, op, cit., p.71.
} 
da função social da literatura e a noção de compromisso intelectual (engagement). As concepções de Sartre, principalmente as argumentações contidas no livro Que é a Literatura? (1947), serviram de fundamento à conversão do escritor em intelectual, aproximando as aspirações profissionais com as preocupações políticas. A noção de engajamento em Sartre tem como base uma filosofia da consciência, que não se reduzia a um engajamento político, fundamentando o ato de engajar-se através da noção intrínseca da liberdade.

Neste sentido, compreendendo que a arte não poderia ser criada artificialmente pelo partido, o ideal de Sartre e sua noção de engajamento implicavam uma alternativa à filiação partidária concreta, permitindo que os escritores conservassem a posição de intelectual como consciência crítica. Além disto, ao abraçar a causa cubana e difundi-la na Europa, como antes havia feito com os movimentos de independências das colônias africanas, Sartre tornou-se um modelo intelectual para as esquerdas ${ }^{36}$. Na entrevista " $O$ intelectual face à revolução", Sartre afirma não considerar a existência do intelectual dissociada dos posicionamentos de esquerda ${ }^{37}$. Sua reflexão é marcada pela ação, entendendo que todo o saber moderno, pelo menos desde Descartes, "é prático", e não mais desinteressado, fortalecendo uma percepção de que o intelectual deveria engajarse nas questões de seu tempo. Desta forma, a escrita para Sartre é posicionamento no mundo, pois escrever é desvendar a situação por um projeto de mudança ${ }^{38}$.

Outra influência na conformação de um pensamento sobre o "ser intelectual" foi o economista norte-americano de esquerda Paul Baran. Num discurso profusamente difundido, El compromiso del intelectual (1960), Baran estabeleceu uma série de distinções entre intelectuais e trabalhadores intelectuais. Baran compreende os trabalhadores intelectuais como fruto da divisão social do trabalho, que se inicia a partir da cristalização precoce de um clero profissional e culmina com o avanço do capitalismo. Assim, o autor especificou que a separação entre a atividade mental e a manual, possibilitada pela expansão contínua da produtividade, converteu-se ao mesmo tempo numa das facetas principais da desintegração progressiva do indivíduo, o que Marx chamava de "alienação do

\footnotetext{
${ }^{36}$ As concepções de Sartre acerca da literatura serão aprofundadas no capítulo II.

${ }^{37}$ SARTRE, Jean-Paul. O escritor não é político. Lisboa: Publicações Dom Quixote (Coleção Vector-6), 1971, p.11.

${ }^{38}$ SARTRE, Jean-Paul. Que é a literatura?. Petrópolis, RJ: Vozes, 2005. (Coleção Textos

Filosóficos), p.28-29.
} 
homem de si mesmo". Esta alienação se expressa não somente no efeito desarticulador sobre o crescimento e o desenvolvimento harmônico do indivíduo, mas também na radical polarização da sociedade em campos excludentes, embora não desvinculados entre $\mathrm{si}^{39}$. A diferença para Baran é que o intelectual se preocupa com o processo histórico total, não como um interesse de natureza tangencial, mas este toma corpo em seu pensamento e influi notavelmente em seu trabalho, ou seja, o intelectual busca sistematicamente relacionar qualquer área específica na qual possa estar trabalhando com os demais aspectos da existência humana $^{40}$. Este esforço constitui uma das características do "ser intelectual" e de suas funções na sociedade:

servir como símbolo e como mentor do fato fundamental de que os aspectos aparentemente autônomos, desarticulados e separados da existência social sob o capitalismo - a literatura, a arte, a política, o ordenamento econômico, a ciência, as condições culturais e físicas do povo - somente podem ser compreendidos (e influídos) se os visualiza claramente como partes da totalidade global do processo histórico. Este princípio, "a verdade é o todo", para usar uma expressão de Hegel, carrega implicitamente a necessidade de negar-se a aceitar como coisa dada, ou considerá-la imune à análise, qualquer parte isolada do todo. Em rigor, a desfetichização dos "valores", "juízos éticos" e ademais, a identificação das causas sociais, econômicas e físicas de seu surgimento, mudança e desaparição, assim como a revelação dos interesses específicos aos quais servem em determinado momento, representa a maior contribuição individual que pode fazer um intelectual à causa do progresso humano. ${ }^{41}$

Baran afirmou que o intelectual era em sua essência um crítico social, com a função de ajudar a vencer os obstáculos que impediam a construção de uma ordem social mais humana e racional. Para o autor, a adesão ao humanismo constitui um axioma de todo esforço intelectual significativo, sem o qual nenhum indivíduo pode considerar-se nem ser tecido como um intelectual. Neste campo, era preciso também superar a postulação obscura da "neutralidade ética", pois o intelectual

${ }^{39}$ Para Baran, esta polarização se interpõe no centro do antagonismo entre as classes sociais, gerando uma espessa névoa ideológica capaz de obscurecer os desafios reais que enfrenta a sociedade. Porque todos os trabalhadores intelectuais têm um evidente interesse comum - e uma vez que são eles que fixam as pautas da respeitabilidade - tendem a enaltecer e proteger sua posição; superestimando sua importância e atividade, colocam-se contra o labor manual. (BARAN, Paul. "El compromisso del intelectual" (discurso pronunciado para a Associação Norteamericana para o Progresso da Ciência, em New York, 27 dez. 1960), publicado em Marcha, Montevidéu, n. 1089, 22 dez. 1961, p.27-29). Todas as edições do semanário uruguaio Marcha estão disponíveis em: <http://biblioteca.periodicas.edu.uy/collections/show/10.>

${ }^{40}$ Para evitar um possível mal-entendido, Baran especifica que os trabalhadores intelectuais podem ser (e algumas vezes são) intelectuais, e os intelectuais são com frequência trabalhadores do intelecto. (BARAN, Paul, op. cit., p.27).

${ }^{41}$ BARAN, Paul, op. cit., p.27-28. 
que cumprisse sua função na sociedade provocaria um conflito com os representantes do status quo, que então o considerariam um agitador, um utópico, e um subversivo ${ }^{42}$.

Essas formulações teóricas representaram na época um novo panorama em relação à política e ao escritor-intelectual ${ }^{43}$. Muitos membros da intelectualidade da esquerda latino-americana citaram abundantemente, também, as formulações de Antonio Gramsci, principalmente o conceito de intelectual orgânico ${ }^{44}$, e do sociólogo norte-americano Charles Wright Mills, que definiu o intelectual como o ator social fundamental na transformação das sociedades pobres e analfabetas do Terceiro Mundo $^{45}$. Como observou Gilman, a convicção expressa por Wright Mills de que as zonas periféricas do mundo proporcionavam condições privilegiadas para a rebelião dos intelectuais contra os grupos dominantes era compartilhada por um amplo grupo da intelectualidade latino-americana, sustentando a afirmação da importância dos intelectuais nas transformações revolucionárias $^{46}$. Wright Mills e Sartre são inclusive citados no emblemático discurso de Fidel Castro, Palabras a los intelectuales (1961), no qual o Primeiro Ministro cubano se dirigiu aos intelectuais para tratar do tema da liberdade de criação dentro do governo revolucionário. Ademais, o contexto social cultural e econômico do continente reforçou a ideia de que para um escritor era inevitável ocupar-se do político, porque, como reconheceu Carlos Fuentes: “Quando os

\footnotetext{
${ }^{42}$ Ibidem, p. 29.

${ }^{43}$ A fluidez entre as categorias escritor e intelectual já possuía uma tradição abundante desde Emile Zola e o "caso Dreyfus", mas é precisamente com a revolução socialista em solo americano que o deslizamento entre as categorias adquiriu contundência na América Latina. Nesta direção, encontra-se o discurso pronunciado por Alejo Carpentier no Primeiro Congresso Nacional de Escritores e Artistas Cubanos, realizado em Havana, em agosto de 1961. O autor declarou que assim como na década de 1920 a preocupação de ordem política restabeleceu o vínculo entre os intelectuais latino-americanos, porém agora com bases mais firmes, já que não se ignoravam nem "os fundamentos científicos do socialismo", nem os princípios constitutivos da unidade continental, nem a identificação dos Estados Unidos como o inimigo comum. (CARPENTIER, Alejo apud GILMAN, Claudia, op. cit., p.61).

${ }^{44}$ Para Gramsci, os intelectuais orgânicos são aqueles que estão conectados ao mundo do trabalho, às organizações políticas e culturais que seu grupo desenvolve para dirigir a sociedade. Além de serem "especialistas" na sua profissão, cabe aos intelectuais orgânicos exercerem funções culturais, educativas e organizativas para assegurar a hegemonia social e o domínio estatal da classe que representam. Os intelectuais orgânicos manifestam sua atividade intelectual no trabalho, no interior da sociedade civil e na sociedade política. (GRAMSCI, Antonio. Os intelectuais e a organização da cultura. Rio de Janeiro: Civilização Brasileira, 1995. 244p.).

${ }^{45}$ WRIGHT MILLS, Charles apud GILMAN, Claudia, op. cit., p.60.

${ }^{46}$ GILMAN, Claudia, op. cit., p.60.
} 
escritores não se ocupam da política, a política termina ocupando-se dos escritores" $" 47$.

O pertencimento à esquerda se converteu em elemento crucial de legitimidade da prática intelectual, embora, segundo Adriane Vidal Costa, nem todos os escritores adotassem posições de esquerda ou se ocupassem das discussões em torno do papel do intelectual, como foi o caso de Gabriel García Márquez, Adolfo Bioy Casares, Manuel Puig ou José Lezama Lima, para citar alguns exemplos de escritores que se mostraram reticentes a converterem-se em intelectuais, no sentido dos debates da época ${ }^{48}$. No início da década de 1990, em uma entrevista, García Márquez declarou que não era um intelectual na acepção completa do termo, porque o intelectual "tem ideias mais ou menos preconcebidas que ele tenta constantemente confrontar com a realidade". Desse modo, o intelectual esforçar-se-ia para interpretar a realidade por intermédio de ideias preconcebidas. García Márquez confessou fazer um exercício contrário, pois interpretava a realidade por intermédio da experiência de vida e do conhecimento do mundo que adquiria no cotidiano ${ }^{49}$.

Isso, contudo, não significava uma abstenção dos debates em torno do socialismo e de Cuba. García Márquez, por exemplo, se eximiu de uma participação mais incisiva no debate intelectual da época, mas não deixou de se posicionar através de seus artigos. Em 1957, García Márquez viajou por vários países socialistas do Leste europeu, onde visitou cidades como Moscou, Budapeste, Kiev e Stalingrado, cujo resultado foi a publicação de uma série de reportagens nas quais o escritor colombiano registrou suas impressões acerca do socialismo na região que, segundo ele, estava longe de ser aquele idealizado por Marx e Engels. Para García Márquez, o socialismo destes países era uma ditadura burocrática e dogmática, presidida pelo secretário do partido comunista ${ }^{50}$. Ainda

\footnotetext{
${ }^{47}$ FUENTES, Carlos apud GILMAN, Claudia, op. cit., p.72.

${ }^{48}$ COSTA, Adriane A. Vidal, op. cit., p.45.

${ }^{49}$ GARCÍA MÁRQUEZ apud COSTA, Adriane A. Vidal, op. cit., p. 262. Aos vinte e cinco anos, o escritor colombiano filiou-se ao Partido Comunista, mas recordou tempos depois que essa curta experiência não lhe havia acrescentado nada. $\mathrm{Na}$ verdade, nunca foi um militante propriamente dito, mas um simpatizante.

${ }^{50}$ Essas reportagens, entre as quais estão: Yo estuve en Rusia, Yo visité Hungria, 90 días en la Cortina de Hierro, La Cortina de Hierro es un palo pintado de rojo y blanco, Berlín es un disparate - publicadas originalmente na revista Cromos, de Bogotá, entre 1957 e 1959 -, despertaram inúmeras críticas no meio intelectual; os de esquerda o acusaram de ter se vendido à CIA, e os "mais liberais" queixaram-se de que o repórter transformara-se meramente "num apóstolo crítico do socialismo". (COSTA, Adriane A. Vidal, op. cit., p. 92-93).
} 
assim, o escritor mantinha sua fé em que o socialismo era o destino da humanidade. Em 1957, após entrevistar Emma Castro, irmã de Fidel Castro, García Márquez publicou o artigo Mi hermano Fidel, no semanário venezuelano Momento, no qual manifestava sua solidariedade com o Movimento Revolucionário 26 de Julho.

Em Cuba, durante toda a década de 1960, coexistiram diversas concepções de intelectual, que ultrapassaram as fronteiras cubanas, tendo ressonância no campo cultural na América Latina e gerando uma série de debates em torno da noção de intelectual e da revolução. Costa ressalta que, de modo geral, o campo intelectual cubano dividiu-se em três posições: a adesão incondicional ao governo revolucionário, o respaldo crítico à Revolução e o exílio ${ }^{51}$. Nesse sentido, o discurso proferido por Fidel Castro, Palabras a los intelectuales, é significativo para uma compreensão dos dilemas que permeavam os debates da comunidade intelectual de esquerda ${ }^{52}$. Em primeiro lugar, Fidel Castro pontuou que a revolução econômico-social deveria inevitavelmente produzir, também, uma revolução cultural. Em segundo, tocou na questão sensível do debate: a liberdade de produção e expressão artística. Para Castro, este era um tema restrito à problemática do conteúdo das criações, uma vez que a Revolução trouxe consigo uma série de liberdades e, por isso, era desnecessária a preocupação quanto a uma possível asfixia do espírito criador. A seu ver, “o artista revolucionário seria aquele que estivesse disposto a sacrificar até a sua própria vocação artística pela Revolução" $"$. E continua:

\footnotetext{
${ }^{51}$ Ibidem, p.58. Essa coexistência não pressupõe harmonia, pois as tensões entre os intelectuais e o processo revolucionário estiveram presentes, em grande medida, nos debates. Alguns dos dissidentes do tipo "ideal" de intelectual segundo o governo revolucionário cubano foram para o exílio a partir de meados da década de 60, por não concordarem com o endurecimento do regime, como foi o caso de Cabrera Infante, Carlos Franqui e Heberto Padilla.

${ }^{52} \mathrm{O}$ discurso de Fidel Castro antecedeu o Congresso Nacional de Escritores e Artistas, sendo proferido em meio às discussões em torno da censura e apreensão do documentário "P.M.", de Saba Cabrera Infante e Orlando Jimenez-Leal, patrocinado pelo suplemento cultural Lunes. O documentário, cujo nome era a abreviatura de Postmeridiem, mostrava a noite de Havana: restaurantes, bares e seus frequentadores, num estilo chamado na época de free cinema. O Icaic (Instituto Cubano de Arte y Industria Cinematográfica), órgão responsável pela autorização de veiculação dos filmes em Cuba, acusava o documentário de ser contrarrevolucionário tanto política como esteticamente. $\mathrm{O}$ caso gerou grande repercussão em Cuba, seguido por uma série de debates entre a intelectualidade, cineastas, artistas e dirigentes da revolução cubana em torno da definição do caráter da arte revolucionária, a liberdade de produção e expressão do artista. (MISKULIN, Silvia Cezar. "Cultura e política na Revolução Cubana: a importância de Lunes de Revolución". São Paulo: Anais Eletrônicos do III Encontro da ANPHLAC, 1998, p.1-10).

${ }_{53}$ CASTRO, Fidel. Palabras a los intelectuales. Site do Ministerio de Cultura de la República de Cuba. Disponível em: <www.cuba.cu/gobierno/discursos/.>
} 
não quero dizer com isso que o artista tenha que sacrificar o valor de suas criações e que necessariamente tenha que sacrificar essa qualidade. Não quero dizer isso! Quero dizer que temos que lutar em todos os sentidos para que o criador produza para o povo e o povo por sua vez eleve seu nível cultural que permita aproximar-se também aos criadores.

Enfaticamente, Fidel Castro pronuncia: “dentro da Revolução, tudo; contra a Revolução, nada”. Um dos propósitos fundamentais da Revolução, segundo Castro, era "incentivar a arte e a cultura, precisamente para que a arte e a cultura" chegassem "a ser um real patrimônio do povo" $" 55$. O discurso de Fidel Castro foi proferido logo após a invasão da Baía dos Porcos, em 1961, tornando-se o emblema de toda uma discussão que mobilizava intelectuais cubanos e estrangeiros. Ademais, como afirma Costa, a liberdade de expressão dos intelectuais cubanos ficou condicionada aos parâmetros estabelecidos nesse discurso, embora, para muitos, não tenha ficado muito claro o que de fato significava estar "dentro da Revolução"

A revista Casa de las Américas canalizou boa parte do debate sobre o papel do intelectual e a função das artes na Revolução ${ }^{57}$. A revista estava vinculada à instituição cultural homônima, fundada em 1959 para promover as relações culturais com a América Latina, cuja direção ficou a cargo de Haydée Santamaría $^{58}$. Os mecanismos pelos quais a Casa de las Américas articulou a rede intelectual foram diversos: conferências, diálogos, mesas-redondas e premiações, realizadas em Havana, para as quais eram convidados escritores estrangeiros e cubanos $^{59}$. As discussões realizadas durante os eventos eram publicadas pela

${ }^{54} \mathrm{Idem}$.

${ }_{56}^{55}$ Idem.

${ }^{56}$ COSTA, Adriane A. Vidal, op. cit., p.61. Após o discurso foi criado em Cuba um novo organismo profissional, a Union de Escritores y Artistas de Cuba, Uneac, presidida por Nicolás Guillen, cuja primeira função foi a publicação de um jornal de debates culturais, Gaceta de Cuba.

${ }^{57}$ Em julho de 1960 foi publicado o primeiro número da revista, organizado por Antón Arrufat. A partir de 1965, passou a ser dirigida por Roberto Fernández Retamar, que permaneceu no cargo até 1989 e reassumiu a direção da revista em 1991. (Ibidem, p.51).

${ }^{58}$ Haydée Santamaría havia participado do assalto ao quartel de Moncada, em 1953, realizado por um grupo de guerrilheiros liderados por Fidel Castro. Santamaría esteve à frente da Casa de las Américas até 1980, ano de seu falecimento. A Casa de las Américas congregava ao seu redor uma ampla estrutura: biblioteca, prêmio literário anual, editora, revista e vários departamentos dedicados à pesquisa literária, além da promoção da música, do teatro e das artes plásticas. Disponível em: <http://www.casadelasamericas.org/.>

${ }^{59}$ A lista de escritores que foram à Ilha a convite da instituição é extensa, entre os quais podemos citar: Carlos Fuentes, Miguel Ángel Asturias, Ezequiel Martínez Estrada, Pablo Neruda, Mario Vargas Llosa, Julio Cortázar, Ángel Rama, entre outros. 
revista Casa de las Américas, onde coexistiam, dentre algumas variações, duas concepções em torno do papel do intelectual: a do intelectual como consciência crítica da sociedade e a do intelectual como organizador da sociedade ${ }^{60}$. Como assinala Costa, a primeira concepção pressupunha o direito de o intelectual colocar-se "fora" da sociedade, criticando, analisando e denunciando seus problemas. A segunda definição, ao contrário da primeira, qualificava o intelectual como aquele que se posicionava "dentro" da sociedade para organizála ou defendê-la com sua inteligência e perspicácia. Neste caso, Fidel Castro e Che Guevara eram as principais referências, como "intelectuais políticos"61.

Tanto o discurso de Fidel Castro, Palabras a los intelectuales (1961), como o de Ernesto Che Guevara, El socialismo y el hombre en Cuba $(1965)^{62}$, no qual rechaça a doutrina do realismo socialista, tiveram ampla ressonância na América Latina, orientando e sendo requeridos numa série de formulações a respeito do escritor-intelectual, o que pode ser observado nas reflexões de distintos intelectuais na Encuesta (pesquisa, inquérito), com o tema El papel del intelectual en los movimientos de liberación nacional, realizada sob a direção do uruguaio Carlos Núñez, em 1966, durante a Conferência da Tricontinental, em Havana $^{63}$. Ao todo, foram interrogados sobre o papel do intelectual nos movimentos revolucionários três europeus e onze latino-americanos: Alberto

${ }^{60}$ Costa dividiu em três fases o modo como a revista tratou o tema: A primeira fase teve início com a fundação da revista e terminou por volta de 1965, quando Fernández Retamar substituiu Antón Arrufat como chefe de redação. A segunda fase começou com a ascensão de Fernández Retamar e teve seu fim com o Congreso Cultural de la Habana, realizado em janeiro de 1968. A terceira iniciou-se em 1968, com o endurecimento da política cultural e o Congreso Nacional de Educación y Cultura, em 1971. (COSTA, Adriane A. Vidal, op. cit., p.64). A coexistência e circulação de diferentes perspectivas sobre o intelectual existiu até fins dos anos de 1960, quando se inicia a terceira fase, que veremos no capítulo III.

${ }^{61}$ Ibidem, p. 193.

${ }^{62}$ Conforme Costa, citando o estudo de Luiz Alberto Moniz Bandeira, o discurso de Che Guevara foi proferido no Seminário Econômico de Argel e enviado ao uruguaio Carlos Quijano para publicação no semanário Marcha (12/03/1965), de Montevidéu. Nesse texto, Che Guevara fez várias críticas à União Soviética, principalmente à sua política econômica, que "os velhos comunistas cubanos" pretendiam adotar na ilha. Ao atacar os comunistas soviéticos, Che Guevara "não só afirmou que o escolasticismo freava o desenvolvimento da filosofia marxista e impediria o tratamento sistemático do período de construção do socialismo, como criticou a política cultural da URSS, instituída desde o tempo de Stalin, por condenar todas as formas de arte posteriores à primeira metade do século XIX, em favor das "formas congeladas del realismo socialista". (Ibidem, p. 65-66).

${ }^{63} \mathrm{O}$ objetivo principal da conferência era construir uma unidade entre as lutas da Ásia, África e América Latina pela libertação nacional, impulsionando a criação de uma "Internacional revolucionária no Terceiro Mundo". Participaram do encontro cerca de 430 representantes da esquerda legal e clandestina (exceto os maoístas) de 27 países dos três continentes e também membros de movimentos nacionalistas mais radicais. Durante a conferência, foi criada a Organização de Solidariedade dos Povos da África, Ásia e América Latina (OSPAAAL). (COSTA, Adriane A. Vidal, op. cit., p.67-68). 
Moravia (Itália), François Maspero e Régis Debray (França), Manuel Rojas e Gonzalo Rojas (Chile), Alejandro Varela (Argentina), Jorge Zalamea (Colômbia), Mario Vargas Llosa (Peru), Roberto Fernández Retamar (Cuba), Lisandro Otero (Cuba) e Manuel Galich (Guatemala). Os cinco últimos eram porta-vozes da revista Casa de las Américas. O tema foi abordado através de distintos critérios, evidenciando uma disparidade, por exemplo, entre os intelectuais europeus e latino-americanos, os primeiros guiados por uma notória busca de rigor sociológico e psicológico, enquanto os segundos por uma imperiosa necessidade de compromisso ou de autodefinição. Embora cada uma das respostas seja marcada pela subjetividade dos autores, a recorrência com que a maioria das respostas se referia a Fidel Castro e a Ernesto Che Guevara como protótipos da inserção do intelectual nos movimentos de libertação eram um modo de vinculação destes intelectuais.

Para o filósofo Régis Debray ${ }^{64}$, a legítima resposta sobre o papel do intelectual somente poderia ser dada pelos camponeses, trabalhadores ou os homens que haviam participado do combate armado, pois apenas estes poderiam dizer se sentem em sua luta a necessidade do intelectual. Ao mesmo tempo, para ele, era de suma importância a teoria revolucionária, sem a qual não há prática. A seu ver, "o valor do intelectual não reside no que este pensa, senão na relação entre o que pensa e o que faz", e neste continente, quem não pensa na revolução "tem todas as probabilidades de estar pensando pouco ou mal". Para Debray, "homens nascidos na América, como Fidel Castro e Ernesto Guevara", eram os verdadeiros intelectuais, "elevados a sua mais alta incandescência",65.

Fernández Retamar comungava com a percepção de Debray, ao formular que os mais capacitados para responder sobre a função do intelectual seriam aqueles que, como Fidel Castro, fizeram parte da vanguarda armada na luta pela libertação nacional, os outros poderiam apenas abordar o tema a partir de 1959, quando a "nova sociedade começou a ser construída". Ancorado ao conceito de intelectual orgânico de Gramsci, Fernández Retamar definiu que o papel do

\footnotetext{
${ }^{64} \mathrm{O}$ filósofo, jornalista e escritor francês Régis Debray tornou-se conhecido por trabalhos como $E l$ catrismo, la larga marcha de la América Latina (1965), publicado originalmente em Les Temps Modernes, e América Latina: algunos problemas de estrategia revolucionaria (1965), editado pela revista Casa de las Américas. Estes estudos fizeram com que ele fosse amplamente conhecido na América Latina, chegando a interessar ao próprio Fidel Castro. Além disto, o discípulo de Louis Althusser viveu em Cuba e em outros países latino-americanos.

${ }^{65}$ DEBRAY, Régis. "Encuesta - El papel del intelectual en los movimentos de liberación nacional” In: Casa de las Américas, Havana, n. 35, março-abril, 1966, p. 85-87.
} 
intelectual passava por uma ordem prática e concreta, o intelectual poderia exercer muitas outras atividades, como ser um jornalista, um professor, um diplomata, um editor, um funcionário, um técnico, etc. Mas não se tratava do segundo ofício habitual de muitos escritores e artistas de todas as partes, senão de uma "exigência do país", o qual, em vista de sua condição subdesenvolvida, "carecia de quadros suficientes". Para ele, a função do intelectual seria a de pensar e interpretar a Revolução, suas raízes, seus vínculos e seu sentido, devendo, sobretudo, servir à revolução, sem "abandonar o olhar crítico", característico de sua essência ${ }^{66}$.

Por sua vez, Alberto Maravia e Vargas Llosa defendiam a autonomia do escritor e da arte diante da luta pela libertação nacional. Para Moravia ${ }^{67}$, um intelectual poderia se enquadrar em várias categorias, o escritor, o jornalista, o político, o militar, ou como, por exemplo, Fidel Castro, um político intelectual. Porém, se tratando de um escritor, o melhor que poderia fazer pela sociedade como intelectual era escrever. Para ele, a atividade artística, diferente de outras atividades mais práticas, é um testemunho, uma representação da realidade e, de tal maneira, é uma representação ambígua, misteriosa como a própria realidade. De acordo com Moravia, "assim como um homem tem o dever de ser um bom cidadão, o escritor tem o dever de ser um bom escritor. A arte é uma atividade autônoma". Desta forma, um escritor poderia ser um escritor político, um escritor comprometido de acordo com o que sente. Sua realidade pode ser política, porém pode também ser uma realidade natural, sensual ou poética, "seus temas dependem de seu sentimento" ${ }^{\circ 6}$.

Por sua vez, Vargas Llosa, além de defender a autonomia da arte e do escritor, fazia uma distinção entre o criador (escritor) e o intelectual. Para ele, ambos deveriam ocupar um posto na luta pela libertação nacional, enquanto cidadãos. Porém, o trabalho do escritor, diferentemente do intelectual, consistia na índole irracional da criação, pois a verdadeira vocação do escritor se manifestava de modo "espontâneo, incontrolável e essencialmente intuitivo". Neste sentido, o

\footnotetext{
${ }^{66}$ FERNÁNDEZ RETAMAR, Roberto. "Encuesta - El papel del intelectual en los movimentos de liberación nacional”. In: Casa de las Américas, Havana, n. 35, março-abril, 1966, p. 87-89. Embora Fernández Retamar não deixe de considerar a crítica como essência do trabalho intelectual, foi principalmente uma noção do intelectual a serviço da revolução que se sobressaiu em suas reflexões, culminando com o livro Calibán (1971).

${ }^{67} \mathrm{O}$ escritor italiano Alberto Maravia ficou conhecido por sua crítica à sociedade europeia do século XX, a qual tachava como hipócrita, hedonista e acomodatícia.

${ }^{68}$ MORAVIA, Alberto. "Encuesta - El papel del intelectual en los movimentos de liberación nacional”. In: Casa de las Américas, Havana, n. 35, março-abril, 1966, p. 92-93.
} 
escritor não poderia pôr esse elemento a serviço de nada de um modo premeditado. Na compreensão de Vargas Llosa, de certa forma, o criador se coloca numa verdadeira duplicidade, ou pelo menos numa "terrível tensão": "quer ser fiel a uma determinada concepção política e ao mesmo tempo necessita ser fiel a sua vocação" ${ }^{\text {"69 }}$. Para o escritor peruano, a literatura poderia servir-se da política, enquanto um dos aspectos do real, pois a literatura se serve de tudo o que forma parte da realidade para construir mundos imaginários, por meio dos quais os leitores conhecem melhor o seu próprio mundo e a si mesmos. Esta concepção sobre a literatura dialoga expressamente com o conceito de romance total, o qual Vargas Llosa seguirá como base e interesse de suas investigações críticas ${ }^{70}$. Ademais, este tipo de compreensão acerca da literatura e da vocação do escritor esteve presente como argumentação em diferentes textos do escritor peruano, desenvolvendo-se de modo aprofundado em sua teoria dos "demônios", e aplicando-a no estudo sobre a obra de García Márquez, publicado em 1971, como analisaremos no capítulo II.

Ao participar da reunião do PEN Club norte-americano ${ }^{71}$, em 1966, Vargas Llosa declarou que na maioria dos países latino-americanos, principalmente no Peru, a vocação literária levava, de uma maneira quase fatal, "ao umbral da revolução ou a uma tomada de consciência política". Isso porque muitos escritores peruanos (e latino-americanos) compreendiam que não podiam "ficar cegos aos problemas que cercavam a cultura e a literatura de seu país", onde uma grande parte da população não tinha acesso à educação, não sabia ler nem escrever. O grande desafio do escritor seria, portanto, mostrar por meio das suas obras as mazelas dessa realidade em decomposição, o que de alguma forma tinha permitido "o nascimento de literaturas ricas, ambiciosas e totais"

\footnotetext{
${ }^{69}$ VARGAS LLOSA, Mario. "Encuesta - El papel del intelectual en los movimentos de liberación nacional”. In: Casa de las Américas, Havana, n. 35, março-abril, 1966, p.97-98.

${ }^{70}$ Sobre o conceito de romance total em Vargas Llosa, consultar o capítulo II deste trabalho.

${ }^{71}$ A mesa-redonda teve como tema "Papel del escritor en América Latina". Além de Vargas Llosa, participaram da mesa-redonda do PEN Club norte-americano Rodríguez Monegal (mediador), Victoria Ocampo, Pablo Neruda, Nicanor Parra e Manuel Balbontin, Carlos Fuentes, Marco Antonio Montes de Oca e Homero Aridjis, Juan Liscano, Haroldo de Campos e Carlos Martínez Moreno. As discussões foram publicadas por Rodríguez Monegal na revista Mundo Nuevo (n.5, nov.1966). As edições da revista Mundo Nuevo, estão disponíveis em: <http://periodicas.edu.uy/v2/minisites/mundo-nuevo/indice-de-numeros.htm>

72 VARGAS Llosa, Mario. "Papel del escritor en América Latina". In: Mundo Nuevo, Paris, n. 5, nov. de 1966, p.27.
} 
Carlos Fuentes, que também esteve presente no encontro, declarou que o grande desafio do escritor na América Latina era se fazer ouvir pelos meios de comunicação de massa, pois o cinema, a televisão e o rádio estavam sob controle dos "mais catastróficos mercenários". Cabia então ao escritor dizer aquilo que "a história não dizia" e que os "meios de comunicação de massa também não diziam", e isso se constituía como um desafio permanente. Para Fuentes, uma das funções concretas do escritor era criar um sentido para o presente a partir do próprio presente ${ }^{73}$. O poeta chileno Pablo Neruda, em sua intervenção, concordou com Vargas Llosa e Carlos Fuentes em que o papel da literatura era "enriquecer o mundo com seu espírito libertador e criativo". Assim como Vargas Llosa, Neruda apontou para os milhões de analfabetos na América Latina, que, segundo ele, era o principal drama que vivia então o escritor. Para o chileno, cabia ao escritor mostrar aos seus poucos leitores os caminhos da liberdade e da justiça ${ }^{74}$.

Estas intervenções pleiteavam uma das tarefas principais a qual se dedicaram os escritores-intelectuais na época, a saber: o encontro de um público interlocutor de suas palavras. O problema da ausência de público foi colocado repetidas vezes como um desafio e, em certa medida, como apontou Gilman, não podemos deixar de reconhecer a contribuição que os escritores, críticos, jornalistas culturais e professores tiveram na formação e criação de público para suas obras ficcionais e intervenções discursivas, uma população que crescia na medida em que a modernização social e econômica ampliava o número de membros até originar um novo setor sócio profissional ${ }^{75}$.

Para muitos intelectuais, um modelo de análise da questão entre escritor e público estava contido no livro de Sartre Que é a literatura? (1947). Nesse livro,

\footnotetext{
${ }^{73}$ FUENTES, Carlos. "Papel del escritor en América Latina". In: Mundo Nuevo, Paris, n. 5, nov. de 1966, p.29.

${ }^{74}$ NERUDA, Pablo. "Papel del escritor en América Latina". In: Mundo Nuevo, Paris, n. 5, nov. de 1966, p.33-34. De acordo com Costa, depois de ter participado da reunião do PEN Club norteamericano, e antes de regressar ao Chile, Pablo Neruda passou pelo Peru, onde foi condecorado com a Ordem do Sol pelo presidente Belaúnde Terry. A participação de Neruda na reunião e a condecoração do governo peruano provocaram uma polêmica entre ele e vários intelectuais cubanos, que viram nas atitudes de Neruda uma traição. Segundo eles, Neruda estaria favorecendo o imperialismo norte-americano e aceitando uma homenagem de um governo que, naquele momento, combatia um movimento guerrilheiro apoiado por Cuba. Na Carta abierta a Pablo Neruda, assinada por mais de cem intelectuais cubanos - dentre os quais Lisandro Otero, Roberto Fernández Retamar e Edmundo Desnoes -, o poeta chileno foi condenado por sua complacência com os inimigos e acusado de ser contrarrevolucionário. A carta foi publicada no jornal cubano Granma e reproduzida na revista chilena Punto final e na revista Casa de las Américas. (COSTA, Adriane A. Vidal, op. cit., p. 76).

${ }^{75}$ GILMAN, Claudia, op. cit., p.85-86.
} 
o filósofo francês considerava que o texto somente adquire sentido estético quando o leitor, pela sua consciência imaginante, cria um significado para as frases, tornando-se um reagente do texto literário. Para Sartre há entre autor e leitor um "pacto de generosidade"76. Assim, o artista deveria dirigir-se a um público concreto, cumprindo uma função específica. O escritor seria, portanto, um provocador, e ao leitor caberia, por meio da imaginação, desvendar o texto com a liberdade que lhe é garantida no exercício da leitura. Em suma, para o filósofo francês, o tema da literatura "sempre foi o homem no mundo", não existindo diferença alguma entre seu tema e seu público ${ }^{77}$.

A necessidade de interpelação de um público leitor se traduziu, por diversas vezes, em discursos que se pautavam na análise da situação do escritor-intelectual na América Latina. Vargas Llosa, por exemplo, no artigo Sebastían Salazar Bondy y la vocación del escritor en el Perú (1966) salientava que, ao assumir a condição de escritor, Salazar Bondy (1924-1964) admitiu uma vocação heroica e marginal, algo que significava pouco menos que a morte civil, uma vez que no Peru a literatura não cumpria sua função, pois a maioria dos habitantes não sabia ou não tinha condições de ler, e a minoria que podia não tinha interesse; "as classes dirigentes peruanas opuseram-se tradicionalmente à literatura e à arte"78. Nestas condições, o escritor era um ser "anômalo", "indefinido", "pitoresco", "excêntrico", admitido ou tolerado com metódica desconfiança, dividindo sua vocação com outras tarefas melhor remuneradas, por uma questão de sobrevivência, o que levava muitos escritores a abandonarem a vocação literária ou ao autoexílio ${ }^{79}$. Neste texto, Vargas Llosa adotou Salazar Bondy como um modelo de escritor-intelectual, pois, por um lado, ele havia assumido sua vocação acima de todas as condições e "status social", e, por outro, teve coragem de declarar-se socialista numa sociedade em que isto significava ser perseguido ou

${ }^{76}$ SARTRE, Jean-Paul. Que é a literatura?. Petrópolis, RJ: Vozes, 2005. (Coleção Textos Filosóficos), p.50-51.

${ }^{77}$ Ibidem, p.126.

${ }^{78}$ VARGAS LLOSA, Mario. [1966] "Sebastián Salazar Bondy e a Vocação do Escritor no Peru". In: Contra vento e maré. Rio de Janeiro: Francisco Alves, 1985.p.94. O artigo foi escrito após o falecimento de Salazar Bondy em Lima, como um modo de homenagear o escritor peruano por suas contribuições à cultura do país.

${ }^{79}$ Segundo Vargas Llosa, o exílio tornar-se-ia uma forma de o escritor enfrentar a si próprio e de buscar outro mundo no qual ele encontrasse "um meio mais compatível com sua vocação", "uma atmosfera de maior densidade cultural" e um "clima mais estimulante". Para além desse exílio físico, Vargas Llosa afirmou existir também um outro exílio: o espiritual. Nessa forma de exílio, o escritor começa a se proteger "contra a pobreza, a ignorância ou a hostilidade do meio, construindo um mundo espiritual onde possa exilar-se, um mundo próprio e diferente". (Ibidem, p.94-101). 
encarcerado. A grande lição de Salazar Bondy, segundo Vargas Llosa, era que ele "soube diferenciar perfeitamente suas obrigações de criador de suas responsabilidades de cidadão", pois não "caiu na ingênua atitude daqueles que subordinam a literatura à militância, acreditando assim servir melhor à sua sociedade" ${ }^{\prime 80}$.

Para o uruguaio Mario Benedetti, essa divisão entre a obra literária e a "responsabilidade humana do escritor" não existia. Tampouco acreditava no compromisso forçado e sem profundidade existencial do escritor, nem na militância que subordinava o texto literário. Apesar de reconhecer que o escritor vivia tempos difíceis, com a possibilidade de ser preso, censurado ou perseguido, o que incluía a vida forçada no exílio, Benedetti afirmava que os escritores tinham conseguido algo muito importante: a audiência. Naquele período, algo que parecia inverossímil havia ocorrido, os autores latino-americanos vendiam mais livros que muitos escritores europeus ou norte-americanos, e isso trazia novas responsabilidades para o escritor e novas interpretações para as relações entre escritor e público. ${ }^{81}$

Em suma, a importância das tarefas do escritor-intelectual aparecia na medida em que eram relacionadas à condição do escritor em sociedades de maioria analfabeta; à tarefa de "despertar" uma consciência crítica no leitor a respeito de sua situação como oprimido; e às perseguições e censuras sofridas pelos intelectuais. Por outro lado, sob o lastro histórico atribuído ao sentido de América Latina, esta se tornou um objeto privilegiado da prática intelectual, enquanto enunciadora da transformação que poderia se estender ao restante do sistema-mundo. Cuba tornou-se o modelo paradigmático do câmbio, fonte irradiadora de uma palavra política e social que buscava forjar um novo sentido de latino-americanidade.

Retomando as ideias de integração e os termos usados por intelectuais do século XIX, dentre os quais podemos citar Simón Bolívar (1783-1830) ${ }^{82}$ e José

\footnotetext{
${ }^{80}$ Ibidem, p.112.

${ }^{81}$ BENEDETTI, Mario apud COSTA, Adriane A. Vidal, op. cit., p.85.

${ }^{82}$ Em "Carta de Jamaica", de 1815, Simón Bolívar emprega o termo "América" ou, muitas vezes, "América meridional" e trata toda a extensa região por "mi patria" ou "mi país". Segundo Roseli Barros Cunha, ao falar em nação, Bolívar tinha em mente a união das várias tendências políticas contra o inimigo do momento, o espanhol. E, para isso, não descartava a possibilidade aparentemente contraditória de que para se tornar livre a América teria de contar com aliados fortes no exterior, como, por exemplo, a Grã-Bretanha e os Estados Unidos. (CUNHA, Roseli
} 
Martí $^{83}$, principalmente em "Nuestra América" $(1891)^{84}$, a rede de intelectuais latino-americanos de esquerda, na década de sessenta do século XX, desejava promover uma integração latino-americana, numa perspectiva da atualidade, não mais contra o colonizador espanhol ou português, mas por meio de um alinhamento a favor da Revolução Cubana e, por sua vez, contra a tentativa de unidade promovida pela política imperialista norte-americana ${ }^{85}$.

\section{2. \\ Redes de sociabilidade e a "nova narrativa latino-americana"}

Durante a década de sessenta, os intelectuais latino-americanos formaram uma poderosa rede de sociabilidade, capaz de promover e renovar a agenda cultural na América Latina. Segundo Claudia Gilman, um dos fenômenos mais

Barros. Transculturação narrativa: seu percurso na obra crítica de Ángel Rama. São Paulo: Humanitas Editorial, 2007, p.279-280).

${ }^{83}$ Conforme Cunha, para Martí, a saída do estado de dependência da América estaria em unir as diferenças. "O intelectual faz uma exaltação ao elemento autóctone em detrimento do estrangeiro, ou, como afirma, ao 'homem natural' em oposição ao 'livro importado"”. Entretanto, assinala a autora que, apesar de Martí enaltecer quem ele considera "mestiço autóctone", o cubano fazia parte de uma elite criolla, que foi na verdade quem promoveu a oposição e lutava contra a dominação estrangeira. "Essas palavras, já demonstram uma preocupação do intelectual cubano com a criação de um representante 'autêntico' da América, o mestiço, que seria o traço comum da 'família de pueblos' americanos". Porém, esta busca pela mescla ainda exaltava um passado indígena sem promover uma valorização do indivíduo - fosse ele indígena ou mestiço - no tempo presente. (Ibidem, p. 280).

84 Apesar das diferenças, Simón Bolívar e José Martí acreditavam que a saída para a América seria a união, e esta deveria ocorrer no nível político-econômico (ainda que com a divisão do continente em países), na forma de governo a ser adotada ou no âmbito social, por meio da valorização do indivíduo mestiço. Segundo Cunha, este parece ser, em linhas muito gerais, o projeto que propiciaria a solução buscada para a América no século XIX. Porém, no caso desses intelectuais, devemos lembrar que Bolívar foi primeiramente um militar que também escreveu ensaios. Por sua vez, Martí foi um homem das letras que participou da guerrilha para independência de Cuba. (Ibidem, p. 280). No século XX, a geração de intelectuais latinoamericanos de esquerda, dentre os quais poderíamos citar Mariano Picón Salas (1901-1965) Ángel Rama (1926-1983), escritores como Mario Vargas Llosa, Carlos Fuentes (1928-2012), Julio Cortázar (1914-1984), entre outros, buscavam a construção da América Latina não por meio das armas, e sim pelas letras, ou seja, culturalmente.

${ }^{85}$ Havia por parte dos Estados Unidos um movimento organizado que buscava promover a unidade latino-americana contra o socialismo que se aproximava com a Revolução Cubana. Em 1948, os Estados Unidos fundam a OEA (Organização dos Estados Americanos), abrindo um ciclo institucional que buscava promover um "pan-americanismo", e a CEPAL (Comissão Econômica para América Latina), que acolhe pela primeira vez a denominação América Latina num organismo internacional. A CEPAL foi criada pela ONU, tendo um papel fundamental nas teorias desenvolvimentistas, ou "teoria da dependência", dos anos cinquenta, elaborada por economistas e sociólogos latino-americanos. Sobre o pensamento social latino-americano, ver: MARTINS, Carlos Eduardo. "Pensamento Social". In: SADER, Emir; JINKINGS, Ivana; NOBILE, Rodrigo; MARTINS, Carlos Eduardo. (Coords.). Enciclopédia Contemporânea da América Latina e do Caribe. São Paulo: Boitempo editorial, 2006, p.925-934. 
importantes da cultura latino-americana deste período foi à constituição de um campo intelectual concebido como parte "operativa da vontade de transformar o mundo". Uma comunidade atuante através do imaginário, que tinha como convicção uma identidade comum baseada na América Latina ${ }^{86}$. Este campo intelectual se estabeleceu por uma complexa trama de relações, desenvolvida através de correspondências, participações nas revistas culturais, casas editoriais, congressos, conferências, jornadas e colóquios.

Nesse processo, existiram vários intentos por organizar e institucionalizar a comunidade intelectual latino-americana, com $\mathrm{o}$ intuito de superar o desconhecimento recíproco entre seus componentes. Desde o Encontro de Escritores da América, em Concepción, no Chile, em 1960; o Congreso de Intelectuales de Concepción, em 1962; passando pelo Encontro de Génova, em 1965; pelo Primeiro Congresso Latino-americano de Escritores, em Arica, no Chile, em 1966; o Segundo Congresso Latino-americano de Escritores, no México, em 1967; o Congresso Internacional de Literatura Ibero-americana, em Carcaras, em 1967; até as múltiplas reuniões e encontros em Havana, os escritores estiveram voltados para as discussões em torno do conhecimento de autores, obras, continente e política. Os esforços por pensar o vinculo entre literatura e política ou entre literatura e sociedade estiveram centrados sobre o problema da comunicação, num sentido pragmático.

O Congreso de Intelectuales de Concepción, em 1962, foi encerrado com a escrita de uma carta endereçada ao diretor da Fondo de Cultura Económica, Arnaldo Orfila Reynal, na qual os intelectuais defenderam que, para "superar nosso isolamento, nosso desconhecimento mútuo", era necessário "encontrar voz comum, unitária e outorgar-lhe força, presença e a divulgação que nossa época - e o destino de nossos povos - exigem" ${ }^{\text {87 }}$. Como sugestão, os intelectuais propuseram que fosse criada "dentro da estrutura editorial da Fondo, uma coleção

${ }^{86}$ GILMAN, Claudia. Entre la pluma y el fusil: debate y dilemas del escritor revolucionário en América Latina. Buenos Aires: Siglo XXI, 2003, p.102-103.

${ }^{87}$ Assinaram à missiva: Héctor P. Agosti, José Bianco (Argentina); Jesús Lara, Gil Imana Garrón, Nilda Núñez del Prado (Bolívia); Thiago de Mello, Carolina María de Jesus (Brasil); Gerardo Molina (Colômbia); Alejo Carpentier (Cuba); Benjamín Carrión (Equador); Carlos Fuentes (México); Augusto Roa Bastos (Paraguai); José María Arguedas, José Miguel Oviedo (Peru); Claribel Alegría (El Salvador); Mario Benedetti (Uruguai); Pablo Neruda, Gonzalo Rojas, Fernando Alegría, Braulio Arenas, Luis Oyarzún, Amanda Labarca, José Donoso, Jaime Valdivieso, Hernán San Martín, e Alfonso Echeverría (Chile). (ALBURQUERQUE FUSCHINI, Germán. "La red de escritores latinoamericanos en los años sesenta". Revista Universum, Chile, Universidade de Talca, n. 15, 2000, p.343). 
popular de escritores ibero-americanos como uma arma efetiva, capaz de influir decisivamente no crescimento de nossa produção e de dar-lhe a divulgação mais ampla e fecunda". 88

Ángel Rama, em 1964, no artigo "La generación hispanoamericana del medio siglo. Una generación creadora”, publicado no semanário uruguaio Marcha, lamentava as dificuldades existentes no conhecimento da literatura hispano-americana, tanto para os leitores em geral como para os próprios críticos e escritores:

Não há literatura de mais difícil conhecimento e sistematização que a chamada hispano-americana. Qualquer outra do mundo ocidental conta com estruturas firmes, claros ordenamentos de valores, bons repertórios de informação, guias postos ao dia, e, na medida em que pertençam a países de amplo desenvolvimento, excelente meios de difusão e de crítica acerca dos mais recentes produtos ${ }^{89}$.

Rama referia-se ao desenvolvimento do sistema literário europeu e norteamericano, em contraposição ao sistema hispano-americano com notórias ausências em termos comparativos, devido às dificuldades materiais e ao "emaranhado hispano-americano que entorpece todas as comunicações, desfigurando os mínimos ordenamentos valorativos ao ponto de reduzir uma literatura inteira a somente um nome casual, ou dar hierarquia passageira a obras perecíveis $" 90$. O crítico uruguaio constatou, neste artigo, a necessidade urgente de um "Serviço de Transmissões da Cultura na América Latina", o que equivaleria a "um verdadeiro serviço público" que aproximasse os escritores, ou pelo menos, permitisse o conhecimento destes entre $\mathrm{si}^{91}$.

Em 1965, no Encuentro de Gênova constituiu-se a Comunidade Latinoamericana de Escritores (CLE), reforçando a ideia de atuação conjunta dos intelectuais. Rama descreveu este encontro como um diálogo "pluri-ideológico" entre marxistas, católicos, conservadores e independentes de esquerda, embora

\footnotetext{
${ }^{88}$ Idem.

${ }^{89}$ Rama, Ángel. "La generación hispanoamericana del medio siglo. Uma generación creadora". Marcha, Montevidéu, n.1217, ago.1964, p.2. [tradução nossa].

${ }^{90}$ Para Rama, a situação se agravava quando eram consideradas as questões políticas, por exemplo, o caso dos escritores cubanos que tinham muitos leitores nos países socialistas e quase nenhum na América Latina. (Idem).

${ }^{91}$ Rama alertava neste artigo para os perigos de uma percepção equivocada da produção literária latino-americana. Nesta época, tratava-se de uma crítica ao não reconhecimento público de autores como, por exemplo, Gabriel García Márquez e Alvaro Cepeda Samudio, o que ocasionava, a seu ver, um entendimento de imobilidade da produção literária. (Idem).
} 
estivessem ausentes representantes da direita liberal" ${ }^{92}$ Na "Declaração de Gênova", publicada pela revista Casa de las Américas, se proclamou a existência da América Latina como unidade, para além da diversidade, e a Revolução Cubana como o acontecimento central da época. No manifesto "Nuestra América”, produzido também durante o encontro, os intelectuais latinoamericanos confirmaram, como "consciência moral", a posição anti-imperialista ${ }^{93}$.

De acordo com Adriane Vidal Costa, uma das formas mais eficazes de articulação da rede intelectual, com membros definidos, com reuniões periódicas e com uma posição claramente estabelecida ante a contingência, foi o Conselho de Redação da revista Casa de las Américas. O Conselho se reunia periodicamente em Havana e regularmente emitia declarações sobre temas da atualidade. Assim, o Conselho opinou sobre as ofensivas norte-americanas em Cuba, a morte de Che Guevara, a detenção de Regis Debray e sobre o aniversário de dez anos da Revolução ${ }^{94}$. Segundo a autora, a figura de Fernández Retamar, que se tornou diretor da revista Casa de las Américas, em 1965, contribuiu muito para forjar essa sociabilidade, agregando ao conselho de redação nomes como Antón Arrufat, Pablo Armando Fernández, Julio Cortázar, Emmanuel Carballo, Ángel Rama, Mario Vargas Llosa, Mario Benedetti, entre outros. Do início da Revolução Cubana até o final da década de 1980, foram realizados inúmeros congressos, simpósios e assembleias, com a participação de quase toda a esquerda intelectual latino-americana. Vargas Llosa e García Márquez, por exemplo, viajavam constantemente a Cuba para participar destes eventos. Além disto, a participação como júri, do concurso literário promovido anualmente pela Casa de las Américas, era uma razão político-cultural para viajar a Cuba. Ser jurado ou agraciado no concurso fortalecia os vínculos dos intelectuais estrangeiros com as instituições culturais cubanas e com a defesa política da Revolução. A produtividade da revista esteve desde o princípio em consonância com a necessidade de tornar conhecidas as transformações revolucionárias no exterior ${ }^{95}$.

\footnotetext{
${ }^{92}$ RAMA, Ángel. "Dos tareas que valen un viaje”. Marcha, Montevidéu, n.1245, fev.1965, p. 29.

${ }^{93}$ GILMAN, Claudia, op. cit., p.112.

${ }^{94}$ COSTA, Adriane A. Vidal. Intelectuais, Política e Literatura na América Latina: o debate sobre revolução e socialismo em Cortázar, García Márquez e Vargas Llosa (1958-2005). 413 f. Tese (Doutorado em História) - Programa de Pós-Graduação do Departamento de História da Faculdade de Filosofia e Ciências Humanas da Universidade Federal de Minas Gerais, 2009, p.54.

${ }^{95}$ Ibidem, p.54-55.
} 
As revistas político-culturais e as seções de cultura dos periódicos tiveram um papel de suma importância na sociabilidade dos intelectuais, assim como na promoção dos autores e romances latino-americanos, constituindo espaços centrais de intervenções, cujos ecos foram crucias para alentar a confiança na potência discursiva dos escritores-intelectuais ${ }^{96}$. No ensaio "Intelectuales $y$ revistas: razones de uma práctica”, Beatriz Sarlo assinalou que a frase "publiquemos uma revista" foi pronunciada centena de vezes por um intelectual latino-americano diante de outros intelectuais. Segundo a autora, esta frase quase sempre estava acompanhada por duas ideias afins: necessidade e vazio, inaugurando ciclos longos ou breves de um impulso até o público, fortemente marcado pela tensão voluntarista de intervir na conjuntura presente. Nesta perspectiva, a frase também significava "façamos política cultural" 97 .

A quantidade de revistas que surgiram ao longo da década de sessenta e setenta (sejam de curta ou longa duração, segundo as condições políticas e as possibilidades de financiamento), dão conta da existência de uma rede de sociabilidade entre escritores e críticos, como também de uma rede de compartilhamento de visões de mundo e projetos entre estas instituições, como é o caso do sistema de empréstimos e colaborações entre as revistas Casa de las Américas, Marcha e "La cultura en México" (suplemento cultural do semanário Siempre! $)^{98}$. Mario Vargas Llosa contribuiu ativamente em várias destas instituições, escrevendo artigos e ensaios, como por exemplo, em Casa de las Américas, Mundo Nuevo, Marcha, Caretas, Primera Plana, Siempre!, Expresso (Lima), Revista Peruana de Cultura (Lima), El Nacional (Caracas), e, Plural (México) $^{99}$. Em 1971, Vargas Llosa, Carlos Fuentes, José Donoso e García Márquez fundaram, em Paris, a revista Libre, que durou apenas um ano.

\footnotetext{
${ }^{96}$ Conforme Gilman, todas as revistas político-culturais desse momento pareciam estar imbuídas da convicção que cumpriam na sociedade um papel semelhante ao do Estado ou dos partidos políticos, conformando um centro de elaboração ideológica. (GILMAN, Claudia, op. cit., p.76-77). ${ }^{97}$ SARLO, Beatriz. "Intelectuales y revistas: razones de uma práctica". In: Les discours culturel dans les revues latino-américaines de 1940 à 1970. América, Cahiers du Criccal, Paris, n. 9-10, Presses de la Sorbonne Nouvelle-Paris 3, 1992, p.9-16.

${ }^{98}$ Sobre este sistema de empréstimo, que incluía também as revistas argentinas El Escarabajo de Oro, sua continuação El Grillo de Papel, e La Rosa Blindada, ver: GILMAN, Claudia, op. cit., p.83-85.

${ }^{99}$ Os três tomos do livro Contra viento y marea reúnem uma quantidade significativa dos artigos, cartas e ensaios produzidos por Vargas Llosa, entre1962 e 1988. No Brasil o livro foi publicado em um único volume, em 1985, pela editora Francisco Alves. Nele estão reunidos alguns textos dos dois primeiros tomos da versão em espanhol, abarcando os anos de 1962 a 1981.
} 
Segundo Gilman, nas revistas da época podemos rastrear o processo constante de reavaliação da produção existente e o intento por construir uma tradição partindo de critérios esteticamente modernos, aproximando-se do horizonte do modernismo hispano-americano e das vanguardas, ao mesmo tempo em que eram rechaçadas as perspectivas estéticas do realismo socialista ${ }^{100}$. Para a intelectualidade latino-americana o que importava basicamente era a busca de uma expressão artística original e nova, para a qual era imprescindível recuperar e explorar ilimitadamente outros horizontes estéticos.

Para Vargas Llosa, um dos ingredientes mais notáveis do chamado "boom narrativo" era a grande amizade que existia entre seus integrantes. O escritor peruano confessou que a maior parte dos escritores do boom mantinha uma relação pessoal de verdadeira "camaradagem” e que as opiniões literárias desses escritores eram-lhe muito úteis ${ }^{101}$. Numa carta endereçada a Joaquín Díez Canedo, editor da Sudamericana de Buenos Aires, Cortázar escreveu:

Faz alguns dias que li os originais de uma excelente romance de Mario Vargas, jovem escritor peruano que ganhou faz uns três anos um prêmio na Espanha por seu livro Los jefes. Radicado em Paris, Vargas terminou a pouco seu último romance que se intitula Los impostores [La ciudad y los perros]. Admiravelmente escrito, conta a vida de um grupo de estudantes limenhos em um colégio militar. É um livro de uma violência, de uma força nada comum em nossos países [...]. Como leitor, sugeri a Vargas a eliminação de alguns episódios que me parecem subsidiários e que tiram a força do enredo central. Se o fez, creio que Los impostores será um dos melhores romances dos últimos anos (e não penso somente na América Latina) $)^{102}$.

A eficácia dessa comunidade intelectual pode ser percebida na promoção do romance Cien años de soledad (1967), de García Márquez. Sempre citado como o grande responsável pelo sucesso da literatura latino-americana na Europa e nos Estados Unidos, Cien años de soledad figura com unanimidade no que foi

${ }^{100}$ GILMAN, Claudia, op. cit., p.77.

101 VARGAS LLOSA, Mario. Entrevistas escogidas. Seleção, prólogo e notas de Jorge Coagila. Lima: Fondo Editorial Cultura Peruana, 2004, p. 49. O fenômeno de expansão da narrativa latinoamericana nos anos sessenta e setenta ficou conhecido como "nova narrativa latino-americana" ou "boom narrativo", sendo este último uma palavra que designa fundamentalmente uma operação de ampliação do mercado. Na terceira seção deste capítulo discutiremos os significados do boom e a percepção de seus agentes.

${ }^{102}$ CORTÁZAR, Julio apud COSTA, Adriane A. Vidal, op. cit., p.137-138. Na época, o romance acabou não sendo publicado pela editora Sudamericana e sim pela editora espanhola Seix Barral. O título original Los impostores foi substituído por La ciudad y los perros (1963). A Sudamericana publicou o romance somente em 1967. No Brasil, foi traduzido como Batismo de Fogo, publicado pela editora Círculo do Livro em 1976. Em 2007, a Alfaguara editou o livro em português, mantendo o título original, A cidade e os cachorros. 
considerado o auge da "nova narrativa latino-americana" e sua produção editorial. Com tiragem inicial de 25.000 exemplares, o livro vendeu uma média de 100.000 exemplares, entre 1968 e fins de 1970, o que significava uma revolução nas vendas do gênero no continente ${ }^{103}$.

De acordo com Claudia Gilman, o sucesso sem precedente de Cien años de soledad era sintoma da existência de um mercado profissional capaz de oferecer uma consagração nunca antes conhecida por autores latino-americanos. Porém, mais significativo foi à efetividade do campo intelectual constituído entre 1959 e 1967, que não somente promoveu o romance de García Márquez, como o escreveu no rol dos cânones latino-americanos ${ }^{104}$. Nessa mesma direção, Adriane Vidal Costa atribuiu à rede intelectual latino-americana de esquerda um papel decisivo na promoção do livro, que atendeu e superou o desejo dessa rede de escritores que queriam tornar a literatura latino-americana (re) conhecida dentro e fora do continente ${ }^{105}$. Segundo o crítico uruguaio Rodríguez Monegal, Vargas Llosa foi um dos promotores mais constantes de Cien años de soledad, elogiando a construção da obra em diferentes meios ${ }^{106}$. Para Vargas Llosa,

A publicação de Cien años de soledad, de Gabriel García Márquez, em 1966 [1967], constituiu um acontecimento literário excepcional: com sua presença luciferina esse romance tem o mérito pouco comum de ser, simultaneamente, tradicional e moderno, americano e universal, volatiliza as lúgubres afirmações de que o gênero está esgotado, em processo de extinção. [...] Graças a Cien años de soledad se consolida mais firmemente o prestígio alcançado pelo romance americano nos últimos anos e este atinge um patamar ainda mais alto ${ }^{107}$.

Anteriormente ao sucesso estrondoso de Cien años de soledad, García Márquez enfrentava dificuldades na sua vida financeira e na difusão de suas obras. Com efeito, o jornalismo ocupava grande parte de seu tempo garantindo-lhe sobrevivência em termos econômicos. Quando retornou da Europa, em fins de 1957, García Márquez aceitou o convite para assumir o cargo de redator do semanário venezuelano Momento, cujo chefe era seu amigo Plínio Apuleyo Mendoza. Neste mesmo ano, o escritor colombiano entrevistou Emma Castro,

${ }^{103}$ RAMA, Ángel. "El boom en perspectiva”. In: Signos Literarios, n. 01, janeiro-junho de 2005, p.190.

${ }^{104}$ GILMAN, Claudia, op. cit., p.97-98.

${ }^{105}$ COSTA, Adriane A. Vidal, op. cit. p.149.

${ }^{106}$ RODRÍGUEZ MONEGAL, Emir. "Madurez de Vargas Llosa". Mundo Nuevo, n. 3, Paris, set.1966, p. 62-72.

${ }^{107}$ VARGAS LLOSA, Mario. [2005]. Dicionário Amoroso da América Latina. Rio de Janeiro: Ediouro, 2006, p.153. 
irmã de Fidel Castro, que estava na Venezuela levantando fundos para a luta armada em Cuba. A entrevista resultou no primeiro texto do escritor colombiano sobre a Revolução Cubana: Mi hermano Fidel. No artigo, ele demonstra sua solidariedade com movimento revolucionário em Cuba, recuperando resumidamente sua história - do assalto ao quartel de Moncada à guerrilha em Sierra Maestra -, além de relembrar o Bogotazo, ocorrido em 1948, na Colômbia $^{108}$.

Em 1959, após o triunfo da Revolução Cubana, García Márquez, junto com outros escritores e jornalistas, foi enviado a Cuba pela revista Venezuelana Gráfica, para cobrir o processo da "Operação Verdade", montado para julgar publicamente os criminosos de guerra da ditadura de Fulgêncio Batista. Este foi o primeiro contato direto de García Márquez com Cuba ${ }^{109}$. Neste mesmo ano, o escritor colombiano, juntamente como Apuleyo Mendoza, foi convidado para trabalhar na agência de notícias do governo revolucionário: a Prensa Latina, tornando-se um dos pioneiros da agência em Bogotá ${ }^{110}$. Como correspondente, sua missão era receber e enviar notícias para Havana. Segundo Costa, o contato direto com os cubanos, através da agência, deixou García Márquez mais politizado e comprometido, possibilitando-lhe exercer a atividade jornalística independente dos centros capitalistas internacionais e de acordo com suas convicções políticas e ideológicas ${ }^{111}$. García Márquez e Apuleyo Mendoza organizavam reuniões, conferências e leituras com a presença de ministros, embaixadores e chefes guerrilheiros no escritório da Prensa Latina em Bogotá.

108 Em 1948, Fidel Castro, como membro da FEU (Federação dos Estudantes Universitários), viajou para a Colômbia para participar da conferência do Movimento Estudantil Latino-Americano em protesto à iniciativa dos EUA em fundar a OEA. A conferência não ocorreu por conta do assassinato do liberal Jorge Eliécer Gaitán, o que desencadeou o Bogotazo, do qual Castro participou. O acontecimento marcou o início da guerra civil colombiana. O governo colombiano da época incluiu Fidel Castro e outros estudantes cubanos, como os supostos responsáveis pelo assassinato de Eliécer Gaitán. (COSTA, Adriane A. Vidal, op. cit. p.93-94).

${ }^{109}$ De acordo com Costa, em princípios de 1956, "quando residia em Paris, no Quartier Latin, García Márquez conheceu o poeta cubano Nicolas Guillén, que o mantinha informado sobre tudo que acontecia em Cuba, principalmente com relação à luta contra a ditadura Batista. Foi quando ouviu falar pela primeira vez do Movimento Revolucionário 26 de Julho. García Márquez se identificou logo de início com o MR 26 de Julho. Ele via nos esforços de Fidel Castro e do movimento, a única esperança para colocar um ponto final na tirania de Fulgêncio Batista". (Ibidem, p.93).

${ }^{110}$ A agência, nesse período, tinha como diretor geral o jornalista argentino Jorge Ricardo Masetti, um velho amigo de Che Guevara. A Prensa Latina foi criada para enviar notícias mais condizentes com a realidade cubana, em vista das constantes deformações que as agências internacionais cometiam ao propagar as notícias da revolução. (Ibidem, p. 96).

${ }^{111}$ Idem. 
Além disso, eles organizaram o Movimento Revolucionário Liberal (MRL), dirigido por Adolfo López Michelsen e chegaram até mesmo a recrutar voluntários para desembarcar na República Dominicana e derrubar o ditador Trujillo Molina. Nessa época, García Márquez, juntamente com Apuleyo Mendoza, criou e dirigiu a revista Acción Liberal ${ }^{112}$.

Após este período, García Márquez foi transferido para a sede da Prensa Latina em Havana, onde permaneceu por três meses para receber treinamento intensivo com vistas a abrir novos escritórios da agência em outros países. Assim, o escritor colombiano foi enviado para trabalhar na agência de notícias cubanas em Nova York. Porém, com a invasão da Baía dos Porcos, em 1961, a tensão nos EUA aumentou, levando García Márquez a abandonar o país. De acordo com Costa, logo em seguida o escritor colombiano pediu demissão da Prensa Latina por não se entender com os "sectários comunistas", que, segundo ele, foram ocupando postos-chave na administração da agência. ${ }^{113}$ Neste momento, García Márquez, via com receio o crescente alinhamento de Cuba com a União Soviética, mas isso não significou o rompimento dele com a Revolução.

Em 1961, García Márquez era um jornalista reconhecido nos meios de esquerda, mas praticamente um escritor desconhecido. Segundo Eric Nepomuceno, ele havia escrito quatro livros e apenas La Hojarasca (1955) fora publicado na Colômbia, sem grande êxito. Neste mesmo ano, García Márquez escreveu seu primeiro roteiro cinematográfico, junto com Carlos Fuentes, El gallo de oro, baseado em um conto de Juan Rulfo. Pelos originais de La mala hora (1962), o escritor colombiano ganhou o Prêmio Esso de Romance, porém, o prêmio não foi suficiente para difundir o livro nem para tirá-lo das dificuldades financeiras $^{114}$.

Em 1962, García Márquez publicou no México, o livro Los funerales de la Mama Grande, que também não teve grande alcance editorial. Em 1964, Ángel Rama, após um encontro com García Márquez no México, realizou uma campanha no sul do continente para difundir melhor o nome do escritor colombiano e seus livros. Nesse intuito esteve à publicação da terceira edição de La Hojarasca pela editora Arca (fundada por Rama, em 1962) e o artigo García

\footnotetext{
${ }^{112}$ Ibidem, p.96-97.

${ }^{113}$ Ibidem, p.98.

${ }^{114}$ NEPOMUCENO, Eric. "Gabriel García Márquez: duas anotações para um perfil”. In: GARCÍA MÁRQUEZ, Gabriel. Cem anos de solidão. Rio de Janeiro: Record, 2009, p.16.
} 
Márquez, gran americano (1964), publicado por Rama, no semanário Marcha ${ }^{115}$. Neste artigo, Rama apresentou García Márquez aos uruguaios como o principal renovador da narrativa americana, "o inventor de uma nova expressão artística do continente" 116 . A vida de García Márquez começou a mudar em 1965, quando se tornou um roteirista bem conceituado e um escritor reconhecido e requisitado por editores de vários países latino-americanos. Sua vida financeira havia melhorado, ele mantinha amigos influentes, dividia o ofício de escritor com o jornalismo e os roteiros cinematográficos.

Ao longo de dezoito meses, entre 1965 e 1966, García Márquez dedicou-se ao romance Cien años de soledad, em seu escritório conhecido como "Cueva de la Mafia" - uma referência ao modo como eram chamados os escritores do boom por seus detratores -, no bairro de San Ángel Inn, no México. Segundo Vargas Llosa, García Márquez dedicava-se com muita disciplina a dar forma ao romance. O escritor colombiano havia pedido que sua esposa Mercedes Barcha não o interrompesse por nenhum motivo (sobretudo, com problemas econômicos). Seus filhos o viam apenas pela noite, quando saia de seu escritório, depois das jornadas extenuantes de oito a dez horas na frente da máquina de escrever, na qual às vezes somente avançava um parágrafo do livro ${ }^{117}$. Após ter terminado os três primeiros capítulos de Cien años de soledad, García Márquez os enviou a Carlos Fuentes, que estava na Europa, e este, imediatamente, escreveu um artigo para revista mexicana Siempre!, no qual apresentava todo seu deslumbre diante da obra. Poucos meses depois, nas revistas Eco (Bogotá), Mundo Nuevo (Paris), Diálogos (México) e Amaru (Lima), apareceram alguns fragmentos do romance, o que provocou grande expectativa em torno do livro ${ }^{118}$.

\footnotetext{
115 Revista política e cultural montevideana, fundada em 1939 e fechada pelo governo militar uruguaio em 1973. Foi relançada, juntamente com a Editora de Marcha (fundada nos anos sessenta) com o nome de Cuadernos de Marcha, por seu diretor Carlos Quijano, em exílio no México, em 1979. Ángel Rama foi diretor da seção literária do periódico Marcha, juntamente com Manuel Flores Mora, entre 1950 e 1951, e novamente a dirigiu entre 1958 e 1968. Continuou sendo colaborador da revista até seu fechamento, voltando a colaborar na nova fase, em Cuadernos de Marcha, até a sua morte em 1983. Sobre a trajetória de Ángel Rama, ver: CUNHA, Roseli Barros. Tranculturação narrativa seu percurso na obra crítica de Ángel Rama. São Paulo: Humanitas Editorial, 2007, 422p.

${ }^{116}$ RAMA, Ángel. "García Márquez, gran americano". Marcha, Montevidéu, n. 1193, fev.1964, p.30.

${ }^{117}$ VARGAS LLOSA, Mario. Gabriel García Márquez: historia de un deicidio. Barcelona: Barral Editores, 1971, p.79.

${ }^{118}$ Ibidem, p. 80.
} 
O ensaísta e escritor chileno Luis Harss dedicou à García Márquez um capítulo de seu livro Los nuestros, publicado em 1966. Harss percorreu a América Latina entrevistando escritores que ele considerava como cânones da nova literatura latino-americana. Em sua lista original figuravam os nomes de Jorge Luis Borges, Miguel Ángel Asturias, Alejo Carpentier, João Guimarães Rosa, Carlos Onetti, Julio Cortázar, Juan Rulfo, Carlos Fuentes e Mario Vargas Llosa. A partir da sugestão de Fuentes, García Márquez foi incluído na lista. Na entrevista, o escritor colombiano antecipou os argumentos de Cien años de soledad e El otoño del patriarca (1975). Nesse sentido, para Claudia Gilman, a participação de García Márquez ocorreu mais por um projeto futuro do que por sua trajetória ${ }^{119}$.

No começo de 1966, García Márquez recebeu uma carta da Editora Sudamericana, de Buenos Aires, propondo-lhe reimprimir seus livros; ele então ofereceu o romance que estava escrevendo e Cien años de soledad apareceu em junho de 1967. A primeira edição se esgotou em poucos dias, o mesmo ocorreu com a segunda, com a terceira e com as seguintes. Em poucos meses, se firmaram dezoito contratos de traduções, em três anos e meio, o livro tornou-se um recordista de vendas, alavancando também as vendas das reedições dos livros anteriores de García Márquez ${ }^{120}$. O reconhecimento internacional do escritor colombiano ocorreu logo em seguida. Por Cien años de soledad, García Márquez recebeu o Prêmio Chianchiano, em 1969, na Itália; o Prix du meilleur livre étranger, em 1969, na França; e esteve entre os 12 melhores livros de 1970 eleito pelos críticos literários dos Estados Unidos. Para Julio Cortázar:

Gabriel García Márquez aporta nestes anos outra prova de como a imaginação em sua potência criadora mais alta invadiu irreversivelmente o romance sul-americano, resgatando-o de sua maçante obstinação em parafrasear a circunstância ou a crônica. Somente assim, inventando a partir de territórios privilegiados e vertiginosos como Macondo, chegaremos a pisar firme em Guanahani. O grito de Rodrigo de Triana começa a sair do mito amável, para designar nossa verdadeira terra, nossos verdadeiros homens ${ }^{121}$.

\footnotetext{
${ }^{119}$ GILMAN, Claudia, op. cit., p.99.

${ }^{120}$ Cien años de soledad foi traduzido e publicado nos Estados Unidos, França, Itália, Finlândia, Brasil, Suécia, Alemanha, Rússia, Noruega, Holanda, Polônia, Roménia, Tchecoslováquia, Iugoslávia (duas traduções: servo-croata e esloveno), Inglaterra, Dinamarca, Japão e Hungria. (VARGAS LLOSA, Mario. Gabriel García Márquez: historia de un deicidio, p.81).

${ }^{121}$ CORTÁZAR, Julio apud VARGAS LLOSA, Mario. Gabriel García Márquez: historia de un deicidio, p.81. [tradução nossa].
} 
Vargas Llosa fala da popularidade alcançada pelo escritor colombiano, no livro Gabriel García Márquez: historia de un deicidio (1971):

De Caracas viajamos a Bogotá [...] e lá pude comprovar, pela solicitude da imprensa e dos autógrafos que lhe pediam na rua, que em seu país o êxito de seu livro havia sido tão grande como na Venezuela. E até na apática Lima, onde viajou depois, convidado pela Universidade de Engenharia - respondeu a perguntas sobre sua vida e sua obra, e suas respostas foram publicadas num folheto-, sua chegada provocou uma verdadeira comoção no âmbito intelectual e universitário ${ }^{122}$.

Vargas Llosa e García Márquez estavam em Caracas para assistir o XIII Congresso Internacional de Literatura Ibero-americana, realizado em 1967, quando se conheceram pessoalmente, antes disso trocavam correspondências e planejavam fazer juntos alguns projetos. De acordo com Vargas Llosa o primeiro encontro ocorreu ainda no aeroporto:

[...] Eu vinha de Londres e ele do México e nossos aviões aterrizaram quase ao mesmo tempo. Antes havíamos trocado algumas cartas, e até havíamos planejado escrever, alguma vez, um romance a quatro mãos - sobre a guerra tragicômica entre a Colômbia e o Peru, em 1931 -, porém, essa foi a primeira vez que nos vimos às caras [...]. Nos fizemos amigos e estivemos juntos as duas semanas que durou o Congresso, nessa Caracas que, com dignidade, enterrava seus mortos e removia os escombros do terremoto. O êxito recentíssimo de Cien años de soledad o havia convertido em um personagem popular $[\ldots]^{123}$.

García Márquez mudou-se com a família para Barcelona em outubro de 1967, local onde já vivia Vargas Llosa e sua família. A amizade entre os dois se aprofundou após o encontro em Caracas, tanto que García Márquez e sua esposa Mercedes Barcha tornaram-se padrinhos do segundo filho de Mario Vargas Llosa e Patricia Llosa, Gabriel Rodrigo Gonzalo cujo nome foi dado em homenagem ao compadre. María Pilar Serrano, no ensaio "El 'boom' doméstico", assinala a amizade familiar que existia entre os escritores latino-americanos que viviam na Europa: 'Sim, éramos todos muito amigos, realmente como 'primos', incluindo as crianças, o mini-boom como alguém o apelidou"124. Segundo Pilar Serrano:

\footnotetext{
${ }^{122}$ VARGAS LLOSA, Mario. Gabriel García Márquez: historia de un deicidio, p.84-85. [tradução nossa].

${ }^{123}$ A primeira reunião do Congresso estava prevista para ocorrer em julho de 1967, porém, devido ao terremoto de 29 de julho que sacudiu a capital venezuelana e deixou um significativo número de vitimas, o encontro foi adiado, sendo realizado em agosto do mesmo ano. (Ibidem, p.82).

${ }^{124}$ O ensaio de Pilar Serrano foi publicado como apêndice, na edição de 1983, do livro do escritor chileno e seu esposo, José Donoso. (PILAR SERRANO, María. "El 'boom' doméstico". In: DONOSO, José. Historia personal del boom. $2^{\mathrm{a}}$ ed. Barcelona: Seix Barral, 1983, p.106).
} 
[...] verdadeira amizade, com profundo carinho, reconhecimento e admiração era a que unia então Mario Vargas Llosa e Gabriel García Márquez. Viviam a uma quadra de distância, "a volta da esquina" literalmente, no bairro barcelonês de Sarriá. Admiravam-se, desfrutando de sua mútua companhia, de suas intermináveis conversas, dos passeios que juntos faziam pelas ruas da cidade e Mario escrevia sobre "Gabo". "Dedicou-lhe dois anos de sua vida, María Pilar" me disse Patricia, o livro-ensaio em que colocou sua admiração por Cien años de soledad, a obra mestra de seu amigo. O livro Historia de un deicidio serviu também a Mario em forma de tese para obter seu doutorado na Universidade de Madrid onde anos antes havia estudado literatura ${ }^{125}$.

Nesse sentido, não é gratuito que Vargas Llosa tenha se dedicado numa tese de doutorado ao exame da narrativa de García Márquez. Na altura da publicação do livro do escritor peruano, a obra de ambos era considerada pela crítica símbolo de uma renovação do gênero romanesco. O livro foi um grande tributo a García Márquez e, em certa medida, consolida o sucesso de vendas e crítica de Cien años de soledad. Os Vargas Llosa e os García Márquez não somente nutriam amizade entre si e os outros latino-americanos, tinham bons amigos entre os catalães, quase todos membros da "famosa gauche divine". Segundo Pilar Serrano, "uma esquerda divina", porém, às vezes, "muito elegante, muito europeia e civilizada", que "lançava moda" e reunia-se à noite "nas profundidades art nouveau da boate Bocaccio". Um dos seus principais membros era o poeta-editor Carlos Barral, o criador do Prêmio Biblioteca Breve ${ }^{126}$.

Esse clima de amizade entre os escritores do boom não foi sustentado ao longo dos anos. A última reunião do grupo foi para comemorar o Natal de 1971, no restaurante catalão, La Fuente de los Pajaritos. Segundo Pilar Serrano, neste encontro estiveram presentes ela e o marido José Donoso; os García Márquez; os Vargas Llosa; Julio Cortázar com sua companheira da Letônia, diretora da sessão espanhola da Gallimard; Carlos Fuentes, com sua companheira Rita Macedo; e o poeta cubano Carlos Franqui, que vivia no exílio depois de ter sido perseguido pelo regime cubano. Nessa reunião, de acordo com a autora, as conversas giraram em torno da grande tensão entre o governo revolucionário cubano e os intelectuais $^{127}$.

Nos anos setenta, por uma série de fatores, iniciou-se um processo de ruptura da rede de sociabilidade intelectual de esquerda latino-americana. Entre os

\footnotetext{
${ }^{125}$ Ibidem, p. 107. [tradução nossa].

${ }^{126}$ Ibidem, p. 117-118.

${ }^{127}$ Ibidem, p. 102-103.
} 
acontecimentos que marcaram a cisão do grupo, podemos citar os posicionamentos desencadeados pela prisão do poeta Heberto Padilla, em Cuba, em 1971, e o desentendimento pessoal entre García Márquez e Vargas Llosa. O escritor peruano rompeu com Cuba, após o "caso Padilla", tornando-se um crítico constante da Revolução, enquanto García Márquez permaneceu fiel a Fidel Castro. Entretanto, o rompimento definitivo ocorreu em 1976, quando os dois escritores protagonizaram uma briga dentro de um cinema mexicano - Vargas Llosa acertou o colombiano com um soco de direita. O motivo do ocorrido nunca foi explicado pelos escritores, dando margem as especulações. De acordo com Costa, a que mais circulou na mídia foi que o desentendimento teria ocorrido por ciúmes e acusações de traição e adultério ${ }^{128}$.

Em 2007, quando foi publicada a edição comemorativa dos quarenta anos de Cien años de soledad, Vargas Llosa foi convidado a escrever o prefácio, mas preferiu encaminhar um fragmento do livro García Márquez: história de un deicidio (1971). Este livro foi orginalmente publicado pela editora barcelonesa Barral Editores, e no mesmo ano, através da parceria Caracas-Barcelona, também foi publicado pela editora venezuelana Monte Ávila. Com um lapso de 35 anos, por decisão de Vargas Llosa, o livro voltou a circular numa nova edição em 2006, compondo a "coleção obras completa" - Vol. IV: Ensaios Literários I -, da editora espanhola Galaxia Gutenberg. O livro Gabriel García Márquez: historia de un deicidio foi à materialidade de uma amizade que o tempo não manteve, mas foi, sobretudo, a afirmação de uma prática e cosmovisão literária. Vargas Llosa contribuiu com este livro para fundar a ideia de que Cien años de Soledad e Macondo eram chaves interpretativas da América Latina, sua expressão simbólica.

Cien años de Soledad consagrou a trajetória de García Márquez, tornando-o conhecido nos países da América Latina, na Europa e nos Estados Unidos. Em sua promoção, diversas camadas são sobrepostas (rede intelectual, estabelecimento de novos cânones pela crítica e revistas culturais, ampliação de público e mercado editorial) demonstrando o desenvolvimento do sistema literário e do campo cultural latino americano da época. O prêmio Nobel de literatura concedido a García Márquez, em 1982, foi o reconhecimento internacional não somente da carreira do escritor - que aos 55 anos de idade, possuía fama internacional e

${ }^{128}$ COSTA, Adriane A. Vidal, op. cit., p.137. 
milhões de exemplares de Cien años de soledad vendidos em todo mundo - mas também de um tipo de representação e pensamento sobre a América Latina.

Dois acontecimentos, após a anunciação do Prêmio Nobel, são significativos de toda uma conjuntura da época. Segundo Gerald Martin, no mesmo dia da divulgação do prêmio, o governo de Washington noticiou que, mesmo com o novo status, García Márquez permanecia sem o direito de receber um visto para os Estados Unidos, pois havia sido banido desde que começara a trabalhar para Cuba, em 1961. Em Bogotá, o Partido Comunista organizou uma manifestação pedindo ao escritor que voltasse ao país como porta-voz dos oprimidos, para salvar a Colômbia. Os jornais chamavam García Márquez de "o novo Cervantes", comparação que seria feita muitas vezes a partir daquele momento ${ }^{129}$.

\section{3.}

\section{"América Latina" como "Linguagem"}

A riquíssima profusão de obras que se editavam e se reeditavam a partir da década de sessenta, marcou definitivamente a historiografia literária latinoamericana, criando uma nova tradição literária, na qual escritores, críticos e leitores participaram ativamente. O desenvolvimento do sistema literário, nos anos sessenta, foi resultado de uma conjunção de fatores: desde a ampliação do mercado editorial aos projetos compartilhados pelos intelectuais, que acentuavam o compromisso de modernização estética na América Latina, promovendo uma revisão da historiografia e do cânone literário. Neste período, a identidade latinoamericana pauta-se na emergência de agendas diversas do campo político-social. A América Latina, idealizada, era percebida como uma entidade orgânica e unitária, harmônica em sua carência, convergente em sua diversidade. Vargas Llosa declarou ter "descoberto" a América Latina nesses anos, pois, antes disso, não havia pensado "no continente como uma comunidade cultural, mas como um

\footnotetext{
${ }^{129}$ MARTIN, Gerald. Gabriel García Márquez: uma vida. Rio de Janeiro: Ediouro, 2010, p.517. Depois do sucesso do Prêmio Nobel, García Márquez usou sua fama em favor da América Latina, tornando-se uma espécie de embaixador itinerante em sua tentativa de aumentar a visibilidade do continente e explicar sua situação de opressão e desigualdade. O escritor tornou-se um representante da esquerda e colaborou na fundação do Habeas, organização internacional em favor dos direitos humanos.
} 
arquipélago de países pouco relacionados entre si"130. Em seu testemunho, o escritor peruano ressalta:

meu descobrimento da América Latina nesses anos capitulou-me a ler seus poetas, historiadores e romancistas, a interessar-me por seu passado e seu presente, a viajar por todos os seus países e a viver seus problemas e suas lutas políticas como se fossem meus. Desde então comecei a sentir-me, antes de tudo, um latinoamericano $^{131}$.

Diversos agentes contribuíram para edificar uma percepção cultural e histórica comum dos países latino-americanos. Um dos fenômenos que na década de sessenta colaboraram com esta discussão foi à expansão da narrativa latinoamericana. Nesta época, a literatura do continente experimentava uma nova dimensão de produção, visibilidade e consagração internacional, que impactou significativamente as reflexões em torno do fenômeno literário e dos sentidos de América Latina.

Circunscrito temporalmente entre a década de sessenta e início dos anos setenta, o fenômeno que ficou conhecido como "nova literatura latino-americana" ou "boom narrativo"132 apareceu, segundo Ángel Rama, originariamente no México e em Buenos Aires (e timidamente em São Paulo onde contribuiu para o fortalecimento dos fracos laços com a América Hispânica), sendo ampliado ao instalar-se em Barcelona ${ }^{133}$. Grande parte dos escritores já haviam publicado seus romances na América Latina e na Europa antes do boom, porém, estas obras não alcançavam uma difusão massiva, se restringindo a um público especializado. Dessa forma, as obras de Julio Cortázar, Miguel Ángel Asturias, Juan Carlos Onetti ou Jorge Luis Borges, apenas alcançavam edições de 2.000 exemplares, e após o fenômeno do boom, as mesmas alcançaram tiragens de 20.000 exemplares

${ }^{130}$ VARGAS LLOSA, Mario. [2005]. Dicionário Amoroso da América Latina. Rio de Janeiro: Ediouro, 2006, p. 07.

131 Idem.

132 Nesse estudo, utilizaremos os termos "nova narrativa latino-americana" e "boom narrativo" conforme utilizado pelos autores que mencionam o fenômeno. Adotamos em nossa análise ambas as nomenclaturas como parte de um mesmo processo.

${ }^{133}$ Para Rama, o surgimento do boom pode ser localizado no ano de 1963, com a publicação de Rayuela, de Julio Cortázar. Entretanto, ressalta que o mercado editorial trouxe para o fenômeno uma série de romances, lançados nas décadas de 1940 e 1950, o que ocasionava uma amplitude temporal do boom. (RAMA, Ángel. "El boom en perspectiva". In: Signos Literarios, n. 01, janeiro-junho de 2005, p.161-208). O ensaio de Rama foi apresentado inicialmente no colóquio The Rise of Latin American Novel, em Washington, 1979. No mesmo ano, foi publicado na revista Escritura, e posteriormente em La novela latino-americana - 1920-1980 (1982). 
anuais, esgotando-se com frequência, e exigindo novas edições, por vezes num mesmo ano ${ }^{134}$.

Neste período, novas dinâmicas foram introduzidas no sistema literário. Em diferentes países se discutia a explosão editorial e se organizavam festivais do livro, onde eram publicadas edições de bolso com preços populares. $\mathrm{Na}$ década de sessenta, os catálogos editoriais mostravam uma reconversão do habitual material estrangeiro a uma porcentagem elevada de produção nacional ou latinoamericana. As editoras que proporcionaram o surgimento da "nova narrativa latino-americana" foram em sua maioria casas oficiais ou pequenas empresas privadas, nomeadas por Ángel Rama como "culturais" para diferenciá-las das empresas estritamente comerciais ${ }^{135}$. Numa enumeração parcial destas "editoras culturais", podemos citar: em Buenos Aires, Losada, Emecé, Sudamericana, Compañía General Fabril Editora, além de editoras menores como Jorge Álvarez, La Flor, Galerna, etc.; no México, Fondo de Cultura Económica, Era, Joaquín Mortiz; no Chile, Nascimiento e Zig-Zag; no Uruguai, Alfa e Arca; em Caracas, Monte Ávila; em Barcelona, Seix Barral, Lumen, Anagrama, entre outras ${ }^{136}$.

Além das editoras, os concursos e premiações garantiam o reconhecimento público dos escritores ou a "descoberta" de novos autores, institucionalizando a renovação dos critérios estéticos, como por exemplo, o prêmio literário oferecido anualmente, em Havana, pela Casa de las Américas; o Prêmio Biblioteca Breve, promovido pela editora barcelonesa Seix Barral; e o Prêmio Rómulo Gallegos, promovido pela editora Monte Ávila em parceria com o Instituto Nacional de

${ }^{134}$ COSTA, Adriane A. Vidal. Intelectuais, Política e Literatura na América Latina: o debate sobre revolução e socialismo em Cortázar, García Márquez e Vargas Llosa (1958-2005). 413 f. Tese (Doutorado em História) - Programa de Pós-Graduação do Departamento de História da Faculdade de Filosofia e Ciências Humanas da Universidade Federal de Minas Gerais, 2009, p. 133.

135 Rama ao designar as editoras que acompanharam a nova narrativa como "culturais" sustenta que pretende realçar uma tendência, manifesta em certas ocasiões, que se opunha a norma comercial de uma empresa. Isto é, a publicação de livros que "previsivelmente teriam pouco público, mas cuja qualidade artística fazia com que elas [as editoras] corressem o risco". Essas editoras foram dirigidas ou assessoradas por equipes intelectuais que manifestavam, segundo Rama, uma responsabilidade cultural, propiciando a publicação de obras novas e difíceis, sobretudo, interpretando as demandas iniciais de um público do mesmo modo novo, "melhor preparado e mais exigente". Contudo, o autor assinala que desse conjunto de materiais, as editoras extraíram seu crescimento relativo, sendo proporcionalmente mais beneficiadas que os próprios autores. A seu ver, as editoras comerciais atendiam "exclusivamente ao rendimento econômico". Ainda que tivessem incorporado aos seus catálogos praticamente todos os títulos vendáveis dos autores do boom, estas editoras de cunho comercial apenas manejavam títulos com alta margem de confiabilidade de vendas, atendendo a dinâmica do próprio sistema que estavam inseridas. (RAMA, Ángel. "El boom en perspectiva", p.174-175).

${ }^{136}$ Ibidem, p. 191. 
Cultura y Bellas Artes da Venezuela ${ }^{137}$. Os anos sessenta foram de grande vitalidade criadora, como ressalta Adriane Vidal Costa, apenas entre 1962 e 1968, apareceram obras como Sobre héroes y tumbas (1961) de Ernesto Sabato; Rayuela (1963) de Julio Cortázar; La ciudad y los perros (1963) de Mario Vargas Llosa e Cien años de soledad (1967), de Gabriel García Márquez, entre outras, que apesar de serem distintas entre si, na época foram lidas como exemplos de uma radical experimentação no campo da literatura ${ }^{138}$.

Para o crítico peruano José Miguel Oviedo, o boom funcionou "como um imã que concentrou a atenção sobre um punhado de novos autores e sobre seus mestres e antecessores, criando assim um desenho ou mapa para ler nossa literatura, especificamente o romance" ${ }^{\prime 39}$. Nas listas que perfilaram os escritores do boom figuravam os nomes de Alejo Carpentier, Miguel Ángel Asturias, Jorge Luis Borges, Juan Carlos Onetti, Julio Cortázar, Gabriel García Márquez, Carlos Fuentes, Mario Vargas Llosa e José Donoso - os cinco últimos eram conhecidos como a primeira fileira do boom -. Autores como Juan Rulfo, Adolfo Bioy Casares, Ernesto Sabato, Guillermo Cabrera Infante, entre outros ganharam projeção internacional em seguida. Cabe ressaltar que, estes nomes não eram uma unanimidade, e às vezes, apareciam em primeiro ou segundo plano ${ }^{140}$.

Em “La tecnificación narrativa” (1981), Ángel Rama sustenta que a chamada "nova narrativa latino-americana" consistiria num movimento - mais do que uma estética -, por apresentar uma pluralidade de orientações, tanto artísticas quanto ideológicas, dentro do que considera os dois eixos que ordenariam a produção literária do continente. Um deles, considerado horizontal, faria referencia às áreas culturais regionais em que a América Latina estaria dividida. $\mathrm{O}$ outro, vertical, apontaria para as estratificações socioeconômicas e culturais

${ }^{137}$ GILMAN, Claudia. Entre la pluma y el fusil: debate y dilemas del escritor revolucionário en América Latina. Buenos Aires: Siglo XXI, 2003, p.92-93.

${ }^{138}$ COSTA, Adriane A. Vidal, op. cit., p. 133.

${ }^{139}$ MIGUEL OVIEDO, José. Dossier Vargas Llosa. Lima: Taurus/Santillana, 2007, p. 55.

${ }^{140}$ Em La rentabilidad del talento (1968), Mario Benedetti contestou as listas do boom, por compreendê-las como uma redução da literatura latino-americana sob poucas figuras do gênero narrativo, colocando numa "segunda fileira" escritores importantes como Juan Rulfo, Juan Carlos Onetti, José María Arguedas, Augusto Roa Bastos, Marta Traba, entre outros. Para Ángel Rama, a concentração da publicidade em torno de alguns escritores pactuava com uma confusão na historiografia literária da América Latina. Rama contestava, principalmente, o fato de Borges encabeçar uma "segunda fila", escritor que, a seu ver, era "o mais audaz renovador da narrativa latino-americana". Para ele, este fato levou a muitos críticos a definirem o boom como um dos clubes mais exclusivistas criados na história cultural da América Latina, um clube que tendia a reduzir-se, a princípio, a cinco figuras. Sobre o debate em torno do boom, ver: COSTA, Adriane A. Vidal, op. cit., p. 131-148. 
produzidas em cada área. O período inicial dessa "nova narrativa" teria ocorrido, segundo Rama, nos anos 1920 - ou seja, a partir da vanguarda que faria oposição aos padrões do romance regionalista. A consolidação da "nova narrativa" viria nas décadas de 1930 e 1940, em decorrência de uma forte urbanização e com o aparecimento das "editoras-culturais". Sua efetiva eclosão aconteceria somente na década de 1960, com o surgimento de um novo público, que nesse momento começava a procurar resposta para a situação vivida nos âmbitos econômicos, técnico, social e ideológico. A seu ver, a "nova narrativa" seria, em termos literários, fruto de uma pluralidade estética verificada na América Latina. Desse modo, encontrar-se-iam, dentro de tal movimento, produções com características díspares ${ }^{141}$.

Embora sob a nomenclatura do boom estejam reunidos diferentes autores, podemos compreender este fenômeno ao nos interrogarmos a respeito da configuração do sistema literário da época. Segundo Antonio Candido, um sistema literário se caracteriza por uma articulação orgânica, triangular, entre um corpo de autores, de obras e de leitores, onde podemos incluir, também, a mediação da crítica literária ${ }^{142}$. Além dos denominadores comuns, sincrônicos "espaciais", há uma dimensão diacrônica, "temporal”, que se constitui quando autores, obras e leituras de outras gerações nacionais são capazes de estabelecer uma causalidade interna. Ou seja, quando são possíveis os reconhecimentos das heranças de uma tradição particular, seja para confirmá-la, negá-la, ou ambos simultaneamente e em graus variados ${ }^{143}$. Para Candido, este é um estágio fundamental na superação da dependência cultural, que torna inclusive mais

${ }^{141}$ RAMA, Ángel. "La tecnificación narrativa”. Hispanoamérica, Gaithersburg, n.30, 1981, p.29. Disponível em: <http://www.jstor.org/stable/20541922>. No artigo "Esto es América" (1962), Rama afirma que a peculiaridade cultural de nosso continente estaria na ocorrência, de modo concomitante, de vários períodos ou tendências literária, que em outras culturas se apresentariam de modo linear. A seu ver, na América se verificaria o que chama de "expressão simultânea de períodos que na história de uma determinada cultura se apresentam como sucessivos". De acordo com o autor, a diversidade de épocas, estilos, direções estéticas e equivalências, seria a prova de que as letras na América desenvolvem-se a partir de uma dinâmica própria. Para Rama, a diversidade seria mais que um traço distintivo: seria um traço positivo que caracterizaria a América. (Rama, Ángel apud CUNHA, Roseli Barros. Transculturação narrativa: seu percurso na obra crítica de Ángel Rama. São Paulo: Humanitas Editorial, 2007, p. 281).

${ }^{142} \mathrm{O}$ conceito de sistema literário é cunhado em oposição ao conceito de manifestações literárias, estas eram fenômenos eventuais, característicos dos primeiros séculos da ocupação colonial nas Américas, que atestavam mais seu vínculo com a transplantação ibérica de práticas europeias para a nova paisagem do que uma articulação orgânica entre elas ou com algum projeto de literatura própria nas terras ocupadas. (CANDIDO, Antonio. Formação da literatura brasileira (momentos decisivos) $6^{\mathrm{a}}$ ed. Belo Horizonte: Editora Itatiaia Ltda, 2000, p.23-25).

${ }^{143}$ Ibidem, p.24. 
fecundo o empréstimo tomado de outras culturas. Nesse sentido, é possível perceber o estabelecimento de um sistema literário no chamado boom, ao notarmos que os escritores sob esta nomenclatura não correspondiam a um reconhecimento geracional, e sim a um reconhecimento de seus denominadores comuns.

Ao conceito de sistema importa, também, a existência de instituições de suporte, tais como as academias, o sistema educacional, revistas, prêmios e casas editoriais. De acordo com Flávio W. Aguiar, à medida que se considera um sistema internacional progressivamente abrangente, o conceito se esgarça. Mas, permanece, sobretudo, a recorrência a um repertório comum de fontes, imagens, metáforas e referências, criando o sentimento e a percepção de um enraizamento, de uma história e de um ritmo comuns e peculiares da vida intelectual ${ }^{144}$. No campo dos estudos literários, a partir dos anos sessenta, com o encontro do sistema de pensamento de Antonio Candido e Ángel Rama - que percebia na conceituação do sistema literário de Candido a chave para elaborar uma visão unitária dos processos literários na América Latina, respeitando seu caráter plural e incluindo o Brasil - se constituiu o fulcro das mudanças das bases reflexivas, corroborando com a visão de que as criações literárias da América Latina podiam ser lidas dentro das balizas de uma história comum.

Em "El boom en perspectiva", Ángel Rama ao analisar o processo de expansão internacional da narrativa latino-americana ressaltou que este foi sustentado por dois aspectos diferentes: o primeiro atende às razões que conduziram a tradução das narrativas latino-americanas a outros idiomas, que não somente relaciona-se com a excelência e a adaptabilidade da narrativa a outros mercados, mas também com a repentina curiosidade, sobretudo dos Estados Unidos, França, Itália e Alemanha, sobre a região que abrigou a revolução socialista cubana. O segundo aspecto, atende aos efeitos que essa recepção no exterior teve sobre os públicos latino-americanos, que viram referendadas suas produções nos principais centros culturais do mundo, fortalecendo o orgulho

\footnotetext{
${ }^{144}$ AGUIAR, Flávio W. "Literatura". In: SADER, Emir; JINKINGS, Ivana; NOBILE, Rodrigo; MARTINS, Carlos Eduardo. (Coords.). Enciclopédia Contemporânea da América Latina e do Caribe. São Paulo: Boitempo editorial, 2006, p.720.
} 
regional e o nacionalismo, em curso durante a década de sessenta ${ }^{145}$. Nesta direção, García Márquez ressaltou que

a grande importância cultural de Cuba na América Latina foi servir como uma espécie de ponte para transmitir um tipo de literatura que existia na América Latina há muitos anos. Em certo sentido, o boom da literatura latino-americana nos Estados Unidos foi causado pela Revolução Cubana. Todos os escritores latinoamericanos dessa geração já vinham escrevendo há vinte anos, mas as editoras europeias e norte-americanas tinham muito pouco interesse neles. Quando a Revolução Cubana começou, houve, subitamente, um grande interesse por Cuba e pela América Latina. A revolução virou um artigo de consumo. A América Latina entrou em moda. Descobriram que existiam romances latino-americanos suficientemente bons para serem traduzidos e equiparados ao resto da literatura mundial $^{146}$.

Para Vargas Llosa, os anos do boom possibilitaram que a Europa e a própria América Latina descobrissem que o "subcontinente dos ditadores e dos mambos era capaz também de produzir literatura" ${ }^{" 147}$. Para ele, a grande diferença de escritores como "Cortázar, Fuentes e García Márquez com seus antecessores na América Latina, é que lhes interessa serem primordialmente escritores, e a propósito de sua vocação" manifestavam uma relação que na América Latina era nova ${ }^{148}$. A declaração de Vargas Llosa ilumina a perspectiva profissional do escritor que teve suas condições de sobrevivência modificadas pela expansão de um mercado consumidor. Trata-se da afirmação de um campo profissional, que não significava o abandono do exercício de outras profissões, tais como o jornalismo ou o magistério - que historicamente eram exercidas pelos escritores devido à carência de um mercado suficientemente estabelecido para absorvê-los -, mas uma alteração nos modos de relação com estas profissões.

Para Julio Cortázar, o fator fundamental do boom foi o fenômeno de expansão do público leitor latino-americano. Ao indagar-se sobre esta questão, ele ressalta: "o que é o boom senão a mais extraordinária tomada de consciência por parte do povo latino-americano de uma parte de sua própria identidade?”, e ainda, “o que é essa tomada de consciência senão uma importantíssima parte da desalienação?"149. A seu ver, o boom não foi apenas um fenômeno dos mass

\footnotetext{
${ }^{145}$ RAMA, Ángel. "El boom en perspectiva”, op. cit., p.162.

${ }^{146}$ GARCÍA MÁRQUEZ apud COSTA, Adriane A. Vidal, op. cit., p. 134.

147 VARGAS LLOSA, Mario. [2005]. Dicionário Amoroso da América Latina, op. cit., p. 90.

${ }^{148}$ VARGAS LLOSA, Mario apud CANO GAVIRIA, Ricardo. El buitre y el ave fénix, conversaciones com Mario Vargas Llosa. Barcelona: Editorial Anagrama, 1972, p. 24.

${ }^{149}$ CORTÁZAR, Julio apud RAMA, Ángel. “El boom en perspectiva”, op. cit., p.168-169.
} 
media, mas estava intimamente ligado ao aumento do número de leitores e ao esforço, em grande medida, dos escritores que viviam fora de seus respectivos países, com meios de vida sumariamente difíceis. Nesse sentido, Cortázar ressalta que um dos aspectos positivos do boom foi mostrar aos europeus que a América Latina também era um território literário e não apenas um lugar onde se "produzia golpes de estados e domavam-se potros"150.

Roberto Fernández Retamar, em sua interpretação sobre o boom, ressaltou a situação da cultura latino-americana dessa década como uma nova etapa da intercomunicação do campo cultural. Para ele, o boom editorial da narrativa seria somente um aspecto secundário; o aspecto mais importante, que não poderia ser desvirtuado, era a nova realidade política latino-americana instituída pelo socialismo, especificamente pela Revolução Cubana. Assim, Fernández Retamar sustentou que

a atual literatura latino-americana, num sentido ou outro, é a literatura do surgimento da revolução latino-americana que por enquanto só triunfou num país, mas cujas raízes e perspectivas o ultrapassam largamente. Sem dúvida, seria simplismo elementar, e por isso facilmente contestável, supor que isto implica uma relação mecânica entre ambos os fatos, ou seja, entre comoção político-social e literatura. A situação é muito mais complexa ${ }^{151}$.

Para o autor, até mesmo os escritores mais indiferentes ou hostis ao processo revolucionário, se beneficiaram quanto à difusão de suas obras ${ }^{152}$. Numa análise da relação dos escritores-intelectuais que se situavam à esquerda do espectro político e a Revolução Cubana, Adriane Vidal Costa ressalta que ocorreu uma via de mão dupla: de um lado, a Revolução Cubana ajudou a promover o boom da literatura latino-americana e, consequentemente, o reconhecimento de vários escritores latino-americanos; por outro, o apoio dos escritores mais renomados do boom a Cuba foi importante para "legitimar" o processo revolucionário, tanto na América Latina quanto na Europa ${ }^{153}$. Sem deixar de situar a importância de Cuba na configuração de um ethos alternativo da modernidade tardia latino-americana, Ana Pizarro ao abordar o processo de internacionalização do romance assinala que:

${ }^{150}$ CORTÁZAR, Julio apud COSTA, Adriane A. Vidal, op. cit., p.135.

151 RETAMAR, Roberto Fernández. "Intercomunicação e Nova Literatura” In: FERNÁNDEZ MORENO, César (coord.). América Latina em sua literatura. São Paulo: Perspectiva, 1972, p.337. ${ }^{152}$ Ibidem, p.338-339.

${ }^{153}$ COSTA, Adriane A. Vidal, op. cit., p.141. 
[...] a indústria cultural europeia havia posto os olhos em uma forma de consciência discursiva que se expressava no romance, de pronto transbordando de vitalidade que esta mesma indústria estimulava e que colocava em evidência formas de entender e explicar o continente. Era um momento em que a ficção impunha à crítica, cujos mecanismos de construção discursiva eram, sem dúvida, próximos ${ }^{154}$.

Nessa época, o romance como gênero foi percebido como um instrumento privilegiado de expressão da América Latina na medida em que conjugava os dois valores supremos da intelectualidade: a aspiração social e o impulso até o novo. Nesse sentido, a superioridade e eficácia do romance eram julgadas em vários planos, que ia desde a renovação da linguagem literária até sua potencialidade como instrumento de conhecimento do mundo. Sem dúvida, a experimentação da linguagem no romance encontra na experiência da poesia latino-americana um fértil campo de interlocução e influência. Na realidade, para falarmos apenas da literatura hispano-americana, a ideia de gênero e de seu exclusivismo linguístico, sobretudo, no que tange às grandes categorias poesia e prosa, já havia sido superada pelo Modernismo de Rubén Darío e seus companheiros. Segundo Haroldo de Campos, a rarefação dos limites demarcatórios entre poesia e prosa com a introdução no romance de técnicas de construção do poema, e a inclusão da linguagem do ensaio e da especulação teórico filosófica no poema -, se fez sentir na produção dos escritores contemporâneos, que fizeram da metalinguagem sua própria linguagem $^{155}$.

Para Campos, o aspecto metalinguístico representava uma revolução que se processou longamente no campo da linguagem da literatura, na sua práxis por assim dizer. Trata-se de um "desnudamento do processo" que, em última instância, significa transparecer a arquitetura da obra à medida que ela vai sendo feita, num permanente circuito autocrítico ${ }^{156}$. Nesse sentido, Campo ressalta que para Jorge Luis Borges, por exemplo, não há praticamente diferença entre ensaio e literatura de imaginação, entre a sua Biblioteca de Babel (1941) e suas Inquisições (1925). Por sua vez, o escritor argentino Julio Cortázar, em Rayuela (1963), toma o próprio romance como tema central da obra, cuja dimensão metalinguística se desenvolve, também, na paródia, seja nas dicções das personagens, seja no

${ }^{154}$ PIZARRO, Ana. El sur y los trópicos. Ensayos de cultura latinoamericana. Alicante: Universidad de Alicante, 2004, p.22. [tradução nossa].

${ }^{155}$ CAMPOS, Haroldo de. "Ruptura dos gêneros na literatura latino-americana". In: FERNÁNDEZ MORENO, César (coord.). América Latina em sua literatura, op. cit., p.295-297.

${ }^{156}$ Ibidem, p. 283. 
tratamento de materiais textuais, de informes científicos às memórias estrambóticas de visionários de província. Nessa altura, de acordo com Campos, a manifestação da paródia no romance deve ser vista como um diálogo de textos ou uma "intertextualidade" 157.

O crítico uruguaio Emir Rodríguez Monegal destacou o questionamento do fundamento do romance e da linguagem como caraterística essencial do processo literário da "nova narrativa latino-americana". Trata-se de uma consciência da estrutura do romance e uma sensibilidade para a linguagem como matéria narrativa que não se limita aos elementos internos da obra - resgate das formas, negação das fronteiras entre os gêneros -, mas também, caminha na direção dos elementos extraliterários - negação das fronteiras geográficas e preocupação do conteúdo com a realidade social $-{ }^{158}$.

De acordo com Rodríguez Monegal, coexistem no processo da expansão narrativa latino-americana três ascensões ou "gerações", que repartem entre si um mesmo mundo, disputando fragmentos da mesma realidade, explorando a linguagem ou transpassando entre si experiências, técnicas, e segredos do ofício $^{159}$. Para o crítico uruguaio, os grandes renovadores do gênero narrativo do século XX, são aqueles escritores que começam a publicar suas narrativas mais importantes a partir de 1940. Para ele, escritores como Miguel Ángel Asturias, Jorge Luis Borges, Alejo Carpentier, Agustín Yáñez e Leopoldo Marechal, liquidaram as heranças do naturalismo, questionando a retórica obsoleta dos romances que elaboraram os mitos centrais de um continente visto de forma romântica sob a égide do romance da terra ou do homem do campo ${ }^{160}$. Estes

\footnotetext{
${ }^{157}$ Ibidem, p.300. O termo intertextualidade foi cunhado por Julia Kristeva com base nos estudos de Mikhail Bakhtin, sobre Fiódor Dostoiévski e François Rabelais. O conceito compreende o texto como um conjunto de enunciados, tomados de outros textos, que se cruzam e se relacionam acarretando uma rede interminável de relações. Para Kristeva, "todo texto se constrói como mosaico de citações, todo texto é absorção e transformação de um em outro texto". (KRISTEVA, Julia. Introdução à semanálise. $2^{\mathrm{a}}$ ed. São Paulo: Perspectiva, 2005, p. 68).

${ }^{158}$ A linguagem referenciada por Rodríguez Monegal não é sinônimo de sistema geral da língua, mas antes sinônimo de fala de um determinado escritor ou de um determinado gênero. A linguagem do romance latino-americano é, para o crítico, feita, sobretudo, de uma visão muito profunda da realidade circundante, visão que deve contribuições fundamentais à obra dos ensaístas e dos poetas. (RODRÍGUEZ MONEGAL, Emir. "Tradição e Renovação". In: FERNÁNDEZ MORENO, César (coord.). América Latina em sua literatura, op. cit., p.149-150).

${ }^{159}$ Ressaltamos que o uso da palavra geração, assim como na análise de Rodríguez Monegal, não está sendo empregada pelas distinções do método geracional, pois elas podem provocar quadros estanques e sinópticos. Pertencer à mesma geração não é garantia de unidade de visão ou de linguagem narrativa, muitos dos criadores do "novo romance latino-americano" escapam mais do que pertencem à sua geração respectiva. (Ibidem, p.148).

${ }^{160}$ Ibidem, p.149.
} 
escritores são, sobretudo, renovadores de uma visão da América e do conceito de linguagem americana, cuja obra se realiza quase simultaneamente com o grupo representado por João Guimarães Rosa, Miguel Otero Silva, Juan Carlos Onetti, Ernesto Sabato, José Lezama Lima, Julio Cortázar, José María Arguedas e Juan Rulfo, cujo principal fator comum é uma concepção do romance que questiona seu próprio fundamento, atacando a forma romanesca ${ }^{161}$. É a consciência da estrutura do romance que se transmite para a geração seguinte, não como herança, mas como atravessamento. Neste grupo, Rodríguez Monegal identifica os escritores: Carlos Martínez Moreno, Augusto Roa Bastos, Clarice Lispector, José Donoso, David Viñas, Carlos Fuentes, Gabriel García Márquez, Salvador Garmendia, Guilhermo Cabrera Infante e Mario Vargas Llosa, cuja experimentação das formas e da linguagem é levada as últimas consequências ${ }^{162}$.

A metalinguagem é um dos procedimentos no qual podemos nos referir à experimentação atribuída a "nova literatura latino-americana". O que também pode ser localizado, entre outras questões, na reestruturação da língua. O fato é que em matéria linguística, o problema da expressão se configura como uma questão literária desde os processos de independência. A imposição das línguas europeias se configura como parte de um processo de dominação das colônias, estabelecendo uma relação complexa e conflitiva das experiências que tendiam a criação das identidades culturais latino-americanas ${ }^{163}$. Para o escritor, crítico e diplomata paraguaio Rubén Bareiro Saguier, a quebra da "pureza" idiomática peninsular, tanto na América Hispânica como no Brasil - ruptura em que não só está presente a fala indígena como o aporte da cultura negra -, é fundamental

\footnotetext{
${ }^{161}$ Para Rodríguez Monegal, estes autores, distintos em suas narrativas, reconhecem e admitem as influências de outros autores, seja nos vestígios deixados em suas obras pelos mestres da geração anterior, ou na influência de autores estrangeiros como Faulkner, Proust, Joyce e mesmo Jean-Paul Sartre. (Ibidem, p. 151).

${ }^{162}$ Ibidem, p. 153.

${ }^{163}$ Segundo Rubén Bareiro Saguier, a tomada de consciência linguística opera-se em dois níveis: o político e o intelectual. Um dos momentos culminantes da problemática da linguagem é o da célebre polêmica Bello-Sarmiento, em 1842. Neste debate, Andrés Bello passa por conservador frente à posição progressista de Domingo Faustino Sarmiento, que proclama a incorporação da "barbárie", da língua popular na elaboração literária. A mesma atitude programática assume José Alencar, no Brasil, que distingue categoricamente entre o dialeto português e o brasileiro. Bareiro Saguier ressalta dois problemas prévios enfrentados na constituição das literaturas nacionais. $\mathrm{O}$ primeiro é a imposição da cultura ocidental na América, vale dizer, o conjunto de valores e normas trazidos pelos conquistadores; o segundo é a elevação da língua europeia como meio de expressão literária, trazendo a colocação do problema da autonomia das letras latino-americanas. Estas questões relacionam-se com as experiências complexas e dramáticas da colonização. (SAGUIER BAREIRO, Rubén. "Encontro de Culturas". In: FERNÁNDEZ MORENO, César (coord.). América Latina em sua literatura, op. cit., p.8-9).
} 
dentro da evolução posterior das letras latino-americanas. Trata-se de um processo de apropriação progressiva, por parte da literatura, de um acervo cultural, em última instância, já existente. Uma criação coletiva realizada por aportes constantes e enxertos no tronco da língua patrimonial ${ }^{164}$.

Ángel Rama ao analisar o impacto modernizador e as "respostas" narrativas do encontro da cultura externa com a interna na América Latina, compreende que esta ocorre em três níveis, a saber: a língua, a estrutura narrativa e a cosmovisão, produzindo um processo de aculturação ou de intercâmbio. No nível da língua, Rama sustenta que nos primeiros regionalistas, a exemplo do romance Doña Bárbara (1924), de Rómulo Gallego (1884-1969), coexistia um sistema dual: de um lado, se notaria o registro da língua literária culta do modernismo ${ }^{165}$, encarnando os ideais dos autores; por outro, existia a presença de um "dialeto" dos personagens, de preferência rural, com a intenção de promover uma ambientação realista. Tais dialetos ou vozes americanas, de modo geral, apareciam entre aspas ou explicados por meio de glossários, procedimento que, a seu ver, refletia a estrutura da sociedade e a condição ambígua do próprio escritor $^{166}$.

Em “Diez problemas para el novelista latinoamericano"(1964), Rama sustenta que a diferença entre a língua oral e a escrita na cultura latino-americana assumiria, através dos tempos, um caráter peculiar. Desde a época colonial, o contraste teria provocado um distanciamento da produção escrita em relação ao público. A escritura seguia os padrões da norma culta castelhana, enquanto a oralidade voltava-se para o cotidiano do indivíduo americano. Entretanto, para o indivíduo letrado tal diferença se mostraria mais conflituosa, uma vez que ele saberia da existência e do poder normativo da Real Academia Española ${ }^{167}$. Nesse sentido, o escritor teria uma clara consciência de que ele, idiomaticamente, é um

\footnotetext{
164 Ibidem, p.14.

165 Segundo Rama, o modernismo havia fixado duas vertentes. De um lado, notar-se-ia uma reconstrução purista da língua espanhola, adaptada principalmente a assuntos históricos, como por exemplo, em La gloria de Don Ramiro (1908), de Enrique Larreta. De outro, teríamos uma língua estritamente literária que realizara uma reconversão culta das formas sintáticas do espanhol americano. (RAMA, Ángel. Transculturación narrativa en América Latina. $2^{\mathrm{a}}$ ed. Buenos Aires: Edições El Andariego, 2008, p.48). Alguns dos textos que compõem o livro Transculturación narrativa en América Latina, publicado em 1982, foram escritos ao longo da década de setenta, especificamente os capítulo I, II, III, IV e V. ${ }^{166}$ Idem.

167 RAMA, Ángel. "Diez problemas para el novelista latinoamericano". In: Crítica literaria y utopía en América Latina. Medelín: Editorial Universidad de Antioquia, 2005, p.30.
} 
ser hibrido, apresentando duas personalidades idiomáticas simultâneas e não sempre harmônicas ${ }^{168}$.

Os herdeiros dos primeiros regionalistas (situados por ele por volta de 1910) seriam os "transculturadores", "regionalistas plásticos" ou "continuadorestransformadores" que teriam promovido um encurtamento na distância entre as "línguas" do narrador-escritor e a do personagem ${ }^{169}$. Para Ángel Rama, este foi o grande salto do romance latino-americano rumo a sua maturidade, pois possibilitou a inclusão dos escritores na mesma linguagem de seus personagens. Estes escritores desenvolveram a fala indígena, espontânea e popular, extinguindo o uso dos glossários, ao mesmo tempo em que instituíram a unificação linguística do texto literário, respondendo a moderna concepção de organicidade artística. A seu ver, esta seria a linha reitora, com as variantes previsíveis, de toda a produção posterior a 1940, que possibilitou um processo de "recriação" da linguagem. Rama cita os exemplos de José María Arguedas (1911-1969), Augusto Roa Bastos (1917-2005) e Manuel Scorza (1928-1983), que teriam forjado uma língua artificial e literária $^{170}$.

Segundo Rama, este procedimento era utilizado tanto por um dos maiores expoentes do cosmopolitismo literário, Julio Cortázar, em Rayuela, quanto pelos escritores procedentes do regionalismo, considerados por ele em trance de transculturación. Tais autores passam, então, a explorar o léxico, a prosódia e a morfossintaxe da língua regional, como maneira de prolongar os conceitos de

\footnotetext{
${ }^{168}$ Ibidem. Conforme assinala Roseli B. Cunha, para Rama, em termos de renovação do idioma literário, nem sempre a contribuição criativa popular seria a mais fecunda. Dessa forma, ele dirá que a partir do contato com uma tendência universalista, teria ocorrido, em alguns, momentos uma volta às fontes espanholas - o que chama de "passo atrás" - que colaboraria no revigoramento da língua literária. (CUNHA, Roseli Barros, op. cit., p.303).

${ }^{169}$ Flavio W. Aguiar ressalta que, o conceito de "transculturação" veio da antropologia, do livro Contrapunteo cubano del tabaco y el azúcar (1940) de Fernando Ortiz, que o opõe ao de "aculturação", para analisar os processos de fusão cultural em cenários de desigualdade social. Pelo conceito de "aculturação", culturas dominantes e hegemônicas assimilariam, quase sem se modificar, elementos de culturas subalternas, remetidas a uma espécie de "passado da humanidade". Pelo de transculturação, as culturas dominantes, ao entrarem em contato com outras culturas, mesmo que subalternas, também se modificam. Resulta desse processo dialético um novo universo cultural, que passa a fazer o papel de uma "nova tradição", com as contradições que a expressão contém. Ortiz estudou a transculturação como processo inconsciente, involuntário. Ao transpor o conceito para o plano da criação literária, Rama incluiu nele os projetos estéticos, culturais e políticos formulados conscientemente. (AGUIAR, Flávio W, op. cit., 722).

${ }^{170}$ RAMA, Ángel. Transculturación narrativa en América Latina, op. cit., p.49. Perspectiva sustentada igualmente por Rama em "Diez problemas para el novelista latinoamericano" (1964).
} 
"originalidade" e "representatividade", tão estimados na literatura latino$\operatorname{americana}^{171}$.

Neste aspecto, é importante assinalar a divisão esquemática realizada por Rama, em sua análise sobre o que chama de "irrupções da modernidade" e as "respostas" literárias a este processo. Para o crítico uruguaio, as inovações inicialmente registradas pela poesia teriam chegado por meio de três grandes impactos na América Latina: a primeira entre 1870-1910, quando de reestruturam os estados europeus, ou ainda, durante a revolução industrial; a seguinte depois da Primeira Guerra Mundial (1914-1918), quando os Estados Unidos se unificam sob a linha econômica do norte, ou com a chamada revolução tecnológica e a terceira atravessando a Segunda Guerra (1938-1945), principalmente, com as consequências do pós-guerra que gerou uma redistribuição dos impérios do Ocidente concedendo a primazia aos Estados Unidos ${ }^{172}$.

Em La tecnificación narrativa (1981), apoiando-se em outro texto escrito na década de 1970, "Medio siglo de narrativa latino-americana (1922-1972)", Rama sustenta que existia uma pluralidade de caminhos derivado do impacto modernizador. No que diz respeito à "nova narrativa", o crítico argumenta que a cosmovisão realista e a fantástica, a atenção referencial a história e sua negação, o manejo da língua culta e a recuperação da fala popular, a expressividade existencial e a impassibilidade objetivante, são opostos que conviveram dentro do movimento em variadas dosificações ${ }^{173}$. Como ressalta Roseli B. Cunha, apesar de enfatizar as pluralidades expressas pela "nova narrativa", Rama apresenta-as em dois polos, que no seu entender existiriam desde as origens da América Latina e, portanto, já teriam fixado seus campos de força. Tais oposições poderiam ser sintetizadas entre a internacionalista - aquela "que registra as sucessivas pulsões externas" - e as autóctones ou acriolladas que também registrariam uma pluralidade de tendências, mas, no sentido de recuperação da cultura tradicional $^{174}$. Para o crítico uruguaio, ambas as operações relacionam-se dentro da clara opção modernizadora, contudo, seus produtos são distinguíveis pela cosmovisão que refletem, pela língua que elegem e os recursos artísticos que põem em funcionamento. Nesse sentido, o crítico uruguaio assinala a coexistência

\footnotetext{
${ }^{171}$ RAMA, Ángel. Transculturación narrativa en América Latina, p.49-50.

172 RAMA, Ángel. "La tecnificación narrativa". Hispanoamérica, Gaithersburg, n.30, 1981, p.30.

${ }^{173}$ Ibidem, p.29-30.

${ }^{174}$ CUNHA, Roseli Barros, op. cit., p.164.
} 
de duas "respostas" diferentes ao impacto modernizador. Rama denomina como "vanguardista cosmopolita", aquela que se abre a perspectiva universal; e "vanguardista transculturadora", cuja escrita realiza-se a partir de situações ou zonas limítrofes, entre culturas tidas como autóctones e a cultura cosmopolita ou modernizadora $^{175}$.

Tais forças vanguardistas elaborariam suas "respostas" não somente às transformações verificadas nos planos socioeconômicos, políticos e culturais, mas também, de modo mais especifico, a algumas inovações técnicas características das letras europeias. Rama apresenta seu esquema baseando-se na existência destas duas "respostas" vanguardistas. Como primeira geração do polo vanguardista cosmopolita figura - aquele que para ele seria seu melhor representante - Jorge Luis Borges (1899-1986); e no polo do vanguardismo transculturador, Miguel Ángel Asturias (1899-1974). Como segunda geração na linha cosmopolita, aponta Julio Cortázar (1914-1984); e na transculturada, Juan Rulfo (1918-1986) e José María Arguedas (1911-1969). E, finalmente, no que considera terceira geração entre os narradores da linha vanguardista cosmopolita, teríamos Carlos Fuentes (1929-2012), e do lado transculturador, Gabriel García Márquez (1927-2014) ${ }^{176}$.

Em Mario Vargas Llosa (1936), principalmente em suas primeiras obras, o crítico uruguaio encontraria uma "resposta" que poderíamos chamar de “intermediária". Nelas, para Rama, "convive o maior esforço de recuperação interna da experiência latino-americana com o maior esforço de adaptação cosmopolita, vinculando-as com uma extrema tensão que detecta sua vontade de escritor" ${ }^{\prime 17}$. A seu ver, Vargas Llosa tinha uma clara percepção dos conflitos vivenciados pelos autores latino-americanos. Estes autores conviviam com

175 RAMA, Ángel. "La tecnificación narrativa", p. 68. Como ressalta Cunha, em Transculturación narrativa en América Latina (1982) o crítico uruguaio evidencia que os autores transculturadores teriam promovido uma volta, um repliegue, como ele diz, aos valores mais específicos da cultura tradicional, rural. No entanto, o crítico alerta que tais valores já estariam transculturados, isto é, teriam sofrido um impacto modernizador. (CUNHA, Roseli Barros, op. cit., p.195).

${ }^{176}$ RAMA, Ángel. "La tecnificación narrativa”, p.69. O crítico uruguaio não deixa de destacar a importância da modernização e, com ela, consequentemente, das ideias vanguardistas, cosmopolitas e urbanas - que constituiriam forças externas - na revitalização da criação interna, regionalismo. Em Transculturación narrativa en América Latina (1982), Rama afirma que os resultados mais bem-sucedidos no processo de transculturação narrativa teriam sido realizados por quatro grandes autores: João Guimarães Rosa (1908-1967); Gabriel García Márquez, Juan Rulfo e José María Arguedas.

${ }^{177}$ RAMA, Ángel. "La tecnificación narrativa", p.81. 
problemas básicos encontrados em sociedades periféricas, ao lado de técnicas narrativas típicas dos países exportadores ${ }^{178}$. Assim, Rama ressalta:

Problemas da Idade da Pedra e técnicas narrativas da Era Eletrônica entram em pugna em La casa verde (1965), sem poder equilibrar-se. Isto é o que constitui o específico da invenção de Vargas Llosa, a originalidade de seu intento, a saber, a assunção do conflito que se faz no nível da escritura. Dado que o plano em que coincidem problemas e técnicas é a língua narrativa (que não é linguagem) seu projeto implica uma modernização da ótica com que reconhece uma realidade fixada, a que então aparece como um sistema de inauguração. De fato, a escritura consigna um protesto ${ }^{179}$.

No artigo "De cómo sobreviene lo humano" (1964), Ángel Rama ao analisar o romance La ciudad y los perros (1963), de Vargas Llosa, ressalta que esta obra vale como um manifesto que tem valor especial num momento em que se diria que os novos narradores americanos "recuperam em um nível distinto, superior, enriquecido pela experiência vanguardista, o realismo romanesco". A este esforço, Rama incluiu Roa Bastos no Paraguai, David Viñas em Buenos Aires, José Donoso em Santiago, García Márquez na Colômbia e Carlos Fuentes no México ${ }^{180}$. Situando o que seria este "novo realismo" Rama declara:

o novo realismo que estamos vivendo está muito longe daquele que marcou o criollismo (ou regionalismo, como se queira) da América, porque incide no novo fenômeno social do continente; a macrocefalia das cidades, sua anarquia, espessa, sanguínea e suja composição, a multitudinária classe média e baixa que assegura caoticamente seus serviços e onde se elabora, como um pano mal amassado, um ser humano distinto, em guerra com a natureza, um homem que parece podre, gerado no artifício e que trata a duras penas de resguardar contra o ceticismo uma aspiração vergonhosa de pureza. Creio que foi em 1942, quando se publicou Tierra de nadie de Juan Carlos Onetti, quando se estabeleceu a primeira radiografia crua desta nova realidade humana ${ }^{181}$.

Não se pode dizer que as preocupações dos escritores como Juan Rulfo, Vargas Llosa, Guimarães Rosa, Alejo Carpentier, Julio Cortázar e García Márquez, sejam inteiramente novas. Alguns dos problemas debatidos pelo realismo tradicional, também o são por estes escritores. De acordo com o equatoriano Jorge Enrique Adoum, a grande diferença é a consciência lúcida da dilaceração do escritor, que busca sua identidade entre dois momentos históricos

\footnotetext{
${ }^{178}$ Ibidem, p.82.

${ }^{179}$ Ibidem, p.82. [tradução nossa].

${ }^{180}$ RAMA, Ángel. "De como sobreviene lo humano". Marcha, Montevidéu, n. 1194, fev.1964, p.29.

${ }^{181}$ Idem.
} 
ou mais, "entre dois mundos ou mais, entre duas ou mais civilizações, numa interminável busca do ser em seu próprio labirinto e no labirinto dos demais" ${ }^{\text {"182 }}$. Para o autor, a "nova geração" dos escritores,

especialmente os narradores, levou até as últimas consequências a vontade de mudar a realidade, e começou por desconfiar dela, por impugná-la e desprestigiála. Ali se origina a violência desta literatura que atrai a cólera de alguns comentaristas e o assombro de muitos leitores. A arte já não está nem quer estar tranquila, já não tem a comodidade daquele que tolera ou aceita a mesma realidade que quer transformar, mas se rebela contra ela, contra sua própria estrutura, contra a rigidez de sua lógica, e concebe a criação como uma realidade em si mesma onde vigoram outras leis, outras noções de tempo, de duração, de espaço, de movimento ${ }^{183}$.

Numa realidade convulsionada, a tensão transforma-se numa tensão criadora. Deste modo, Adoum enfatiza que a literatura fez-se antiliteratura. A seu ver, é a consciência de uma verdade caótica, barroca ${ }^{184}$ e surrealista ${ }^{185}$ dos países da América Latina, que se exprimiu nas múltiplas formas que vão desde o rigor de Borges até a inesgotável riqueza de Guimarães Rosa ou o aparente "esquecimento" do estilo de Cortázar ${ }^{186}$. Do esforço de acumulação e reelaboração, o realismo da "nova narrativa" se configura como a conquista da liberdade da imaginação, cuja luta com a linguagem se concentra numa maior preocupação expressiva. Este aspecto coincide com a formação de um fenômeno mais amplo, de desmistificação e recusa das estruturas sociais e culturais, de revolução sexual, de novas normas e usos da vida, de dissolução dos gêneros e

182 ADOUM, Jorge Enrique. "O Realismo de outra realidade". In: FERNÁNDEZ MORENO, César (coord.). América Latina em sua literatura, op. cit., p.213.

${ }^{183}$ Idem.

${ }^{184}$ Para Adoum, a realidade da América Latina é barroca, desde o estilo de suas selvas, sua língua, até o modo do comportamento humano. A seu ver, a grande diferença do barroco literário latinoamericano da "nova narrativa" é que este adquire uma intenção voluntária, quando o escritor reage contra o esquematismo e a descarnadura verbal que o precederam, quando este se dá conta de que uma de suas tarefas, não menos importante do que as demais, é buscar e criar uma linguagem, reestruturar ou redescobrir seu próprio idioma. (Ibidem, p.213-214). Nesta direção, o escritor e crítico cubano Severo Sarduy denominou como uma representação estética neobarroca a experimentação literária da "nova narrativa" latino-americana. Para ele, a linguagem do barroco se define basicamente pela busca sempre frustrada do objeto perdido, de um processo de artificialização - substituição, metáfora, proliferação, metonímia, condensação, paródia, etc. -, de ambiguidade e difusão semântica que lhes são próprios. A estes procedimentos, somam-se as máscaras e a indiferença dos gêneros - exibidos através da intertextualidade -, como característica da poética literária da região. (SARDUY, Severo. "O Barroco e o Neobarroco". In: FERNÁNDEZ MORENO, César (coord.). América Latina em sua literatura, op. cit., p.161-178).

${ }^{185}$ Trata-se de um surrealismo que está muito mais próximo da imaginação popular do que da crônica vermelha do realismo.

${ }^{186}$ ADOUM, Jorge Enrique. “O Realismo de outra realidade”, p.211. 
formas artísticas que projetam a criação de uma sensibilidade e de um estilo próprio, produzindo o chamado apogeu do romance latino-americano.

Em Conversación en La Catedral (1969), Vargas Llosa aproveita as técnicas (descontinuidade cronológica, monólogos interiores, pluralidade dos pontos de vista e dos falantes) para orquestrar algumas visões ao mesmo tempo muito modernas e tradicionais do Peru. Como ressalta Antonio Candido, desde $L a$ ciudad y los perros (1963), aparece nas obras de Vargas Llosa uma refinada tradição do monólogo interior, que "sendo de Marcel Proust e de James Joyce, é também de Dorothy Richardson e Virgínia Woolf, de Alfred Doblin e de William Faulkner" - este último influência constante, referenciada pelo próprio autor. Em todo caso, como afirma Candido, Vargas Llosa aprofundou as técnicas e as fecundou, ao ponto de torná-las "coisa também sua". Não há imitação, nem reprodução mecânica, mas sim participação nos recursos que se tornaram bens comuns $^{187}$. No estilo de Vargas Llosa, misturam-se temas sociais e formas imaginárias, com preponderância do social. Sua renovação é, segundo Rodríguel Monegal, "uma nova forma do realismo; um realismo que abandona o maniqueísmo e o romance de protesto e que sabe que o tempo tem mais do que uma dimensão, mas que não se decide nunca levantar os pés da sólida e atormentada terra" $" 188$.

Com efeito, as diversas interações da linguagem e as tensões entre o local e o global, produziram um processo de interiorização da modernidade no campo literário. Cada vez menos a Europa proporcionava os parâmetros estéticos e cada vez mais o foco se colocava sobre o próprio latino-americano. Este processo, iniciado com as vanguardas dos anos vinte, no qual Pedro Henríquez Ureña destacou a entrada na modernidade como um processo de autoafirmação, uma "busca de expressão própria" "189, é potencializado, nos anos sessenta, pelas urgências das agendas políticas, econômicas, sociais e culturais na América Latina. Nesse sentido, os escritores-intelectuais propuseram, através de suas obras ficcionais e ensaísticas, a invenção de mundos como traço da modernidade. Tratase de uma produção de sentidos que desatava a visão do continente produzida pelo

${ }^{187}$ CANDIDO, Antonio. "Literatura e subdesenvolvimento". In: FERNÁNDEZ MORENO, César (coord.). América Latina em sua literatura, op. cit., p.356.

${ }^{188}$ RODRÍGUEZ MONEGAL, Emir. "Tradição e Renovação". In: FERNÁNDEZ MORENO, César (coord.). América Latina em sua literatura, op. cit., p.154.

${ }^{189}$ HENRÍQUEZ UREÑA, Pedro apud PIZARRO, Ana. El sur y los trópicos. Ensayos de cultura latinoamericana. Alicante: Universidad de Alicante, 2004, p.30. 
outro - o outro europeu, o outro estadunidense -. Octavio Paz, ao se referir à obra de Borges, menciona este como um fator fundante da modernidade literária e da percepção do latino-americano. Para ele, Borges "não só postula a inexistência da América, mas também a inevitabilidade de sua invenção”. Segundo Paz, nossa literatura é a tentativa de fundar a realidade, um empreendimento da imaginação. Mas, fundar um mundo, conclui ele, é ao mesmo tempo inventar e resgatar o real. Um processo que contribuiu de maneira notável para firmar uma perspectiva da diversidade cultural dos países da região ${ }^{190}$.

A apreensão do sistema literário, das décadas de sessenta e setenta, nos permite olhar a literatura e a construção de uma ideia de América Latina a partir dos dados comuns. Entretanto, é preciso considerar os diferentes intentos de construir um mundo - uma lógica de sentido - através do material literário. Como assinala o chileno Hugo Achugar, a América Latina - enquanto construção político-cultural - é como uma tela na qual se projetam ou se encobrem diversos projetos sociais e culturais de classes, gêneros e etnia ${ }^{191}$. Isto é, existe como uma problemática que demanda reflexão e trabalho, que ultrapassa as representações que os intelectuais produziram sobre suas experiências múltiplas e contraditórias. No âmbito literário, a existência de uma pluralidade de formas, linguagens e cosmovisão dentro da "nova narrativa latino-americana" expressa uma modernidade conflitiva, intrínseca a estrutura do sistema literário ou dos sistemas da época ${ }^{192}$.

Nesse sentido, podemos dizer que enquanto alguns escritores se firmavam trabalhando com uma temática mais universal, influídos pelas grandes cidades e o uso de técnicas narrativas modernizadas em diálogo com diversas correntes literárias; outros escritores, cuja estética elabora-se numa visão autóctone do mundo irão tencionar e complexificar o discurso universalista, sobretudo, em sua

${ }^{190}$ PAZ, Octavio apud SUCRE, Guillermo. "A nova crítica". In: FERNÁNDEZ MORENO, César (coord.). América Latina em sua literatura, op. cit., p.270-271.

${ }^{191}$ ACHUGAR, Hugo. Planetas sem boca: escritos efêmeros sobre Arte, Cultura e Literatura. Belo Horizonte: Editora UFMG, 2006, p.56.

${ }^{192}$ Em "Sistema Literario y sistema social en Hispanoamérica" (1975), Rama a partir da ampliação do conceito de sistema literário de Antonio Candido perceberá a existência de sistemas paralelos, concomitantes. A coexistência do que chama de vários "sistemas literários", "sequencias literárias", ou ainda "sincronias complexas" é percebida não numa polarização, mas numa situação onde o conflito não se solucionaria. Ou seja, uma "coexistência conflitiva" entre o que chama de orientação "cosmopolita", "realista-crítica" ou "narrativa social". Em "la tecnificación narrativa" (1981), como vimos anteriormente, este conflito se daria entre o que o crítico nomeia como força "vanguardista cosmopolita" e "vanguardista transculturadora". Sobre a configuração dos sistemas literários no pensamento crítico de Ángel Rama, ver: CUNHA, Roseli Barros, op. cit., p.43-54. 
relação com o boom, percebido como uma simplificação da experiência narrativa, trazendo consigo uma aproximação perigosa entre o campo cultural e o campo econômico. Uma das polêmicas que aludem a esta questão foi desencadeada por Julio Cortázar e o escritor peruano José María Arguedas, que teve início em 1967 reverberando até 1969, quando foi encerrada pelo suicídio de Arguedas. O ponto central, do debate Arguedas-Cortázar foi à defesa, respectivamente, do nacional e do cosmopolita como determinante da prática literária do escritor latinoamericano na década de sessenta ${ }^{193}$.

Essas divergências manifestavam-se, também, nos projetos institucionais. Neste caso, um dos antagonismos, principais, envolvia os projetos editorias da revista Casa de las Américas e Mundo Nuevo. A primeira tinha como projeto uma discussão do papel do escrito-intelectual na revolução, num âmbito de incitação ao nacional; a segunda buscava garantir a autonomia do escritor-intelectual diante do campo político, organizando-se em torno do eixo do cosmopolitismo ${ }^{194}$. Para a revista Mundo Nuevo, que refletia em grande medida as visões de seu dirigente Rodríguez Monegal, era preciso respeitar as fronteiras entre o político e o literário. Nesse sentido, a revista organizava-se em torno do reconhecimento pleno dos escritores por seus valores estéticos, não por seu grau de compromisso com as tarefas revolucionárias, defendendo a liberdade de criação frente aos imperativos do real. Por sua vez, a presença do político-histórico na produção literária aparecia como uma exigência da conjuntura em diversas regiões da América Latina, com os ecos da Revolução em Cuba. Dentro deste contexto, nas páginas da revista Casa de las Américas, como ressalta Idalia Morejón Arnaiz, é fácil identificar todo um processo de estetização do político, que incorpora à análise do literário, valores políticos, morais e éticos posto em circulação pelos discursos dos líderes do governo revolucionário cubano. Esses discursos tinham um forte conteúdo

\footnotetext{
${ }^{193}$ Sobre a polêmica Arguedas-Cortázar, ver: COSTA, Adriane A. Vidal, op. cit., p.164-176.

${ }^{194}$ Outro aspecto que deu sustentação as divergências entre a revista Casa de las Américas e Mundo Nuevo, consistia nas discussões sobre o financiamento da revista Mundo Nuevo, pelo Departamento de Estado dos Estados Unidos, que era tido como uma vinculação do projeto aos interesses da CIA. Ángel Rama considerava o projeto da revista Mundo Nuevo, como uma "fachada cultural" dos Estados Unidos, cuja penetração na América Latina assumiu a identidade de patrocinador cultural, mediante ao financiamento de eventos públicos e concessões de bolsas de estudo aos escritores. A substituição de revistas, como por exemplo, a extinção de Cuadernos e o nascimento da Mundo Nuevo, era para Rama uma indicação da crescente despolitização, caminhando em direção ao ideal da "neutralização" que era uma nova forma de ação. (RAMA, Ángel. "Las fachadas culturais". Marcha, Montevidéu, n.1306, jun.1966, p.30-31).
} 
latino-americanista e terceiro-mundista, a partir do qual se pretendia revitalizar o integracionismo de cunho bolivariano ${ }^{195}$.

Um fator fundamental na construção dos discursos sobre a América Latina relaciona-se com a experiência do exílio. Os escritores latino-americanos mais conhecidos na década de sessenta estavam quase todos, por diferentes circunstâncias, exilados na Europa. Como por exemplo, Julio Cortázar, Mario Vargas Llosa, José Donoso, Gabriel García Márquez, entre outros. Nesse sentido, existe um aspecto da identidade que se constrói a partir da mobilidade. Para Pierre Rivas, foi no exílio, e pelo exílio, que o escritor latino-americano redescobriu "o rosto de sua pátria, a vontade de assumi-la e ilustrá-la. Visto como desvio, o exílio se desvela como retorno e emergência do nacional. Tal é a função do exílio: um enraizamento no ethos nacional"196.

Esse ethos nacional emergente a partir do caráter do exílio desdobrou-se em diferentes perspectivas, estabelecendo uma relação de alternância entre proximidade e distância nos modos de observação e compreensão das sociedades latino-americanas. Por um lado, o escritor em sua terra natal sentia-se um exilado, escrevendo num país em que grande parte da população era analfabeta, mobilizando uma língua europeia colonizadora, mas carregada de um linguajar local. Por outro, o olhar deslocado pelo exílio gerou uma perspectiva crítica, tanto da Europa como do seu próprio país ou do continente. Essa questão influiu na maneira como os intelectuais pensavam a América Latina e percebiam sua função como intelectual, trazendo grandes problemas e tensões ao mesmo tempo em que abriam diversas possibilidades de busca de soluções. No plano estético e linguístico, essas questões eram mediadas pelos debates em torno do caráter regional, nacional, universal ou cosmopolita da literatura.

Para Julio Cortázar, (que viveu em Paris, de 1951 a 1984,quando faleceu) o "contato pessoal com as realizações da revolução, a amizade e o diálogo com escritores e artistas" fizeram com que ele entrasse em contato "com a realidade latino-americana" da qual se sentia "tão afastado no terreno pessoal"197. Segundo o escritor argentino, era

195 MOREJÓN ARNAIZ, Idalia. Política y polémica en América Latina: Las revistas Casa de las Américas y Mundo Nuevo. México: Ediciones de Educación y Cultura (Colección Polémicas), 2010, p.255.

${ }^{196}$ RIVAS, Pierre apud COSTA, Adriane A. Vidal, op. cit., p.157.

${ }^{197}$ CORTÁZAR, Julio apud COSTA, Adriane A. Vidal, op. cit., p.88. 
[...] muito desgastante ter de repetir aos localistas que os livros responsáveis por aquilo que se chamou de boom - palavra idiota, além de tudo inglesa, ironicamente aplicada ao contexto latino-americano - e que determinaram a irrupção de uma nova literatura latino-americana, foram livros escritos por sujeitos que não estavam lá. García Márquez, Vargas Llosa, eu; sem dúvida gente que tinha o que dizer latinoamericanamente. A prova foi à reação admirável dos leitores latinoamericanos: surgiu na América Latina uma consciência sobre os seus escritores que até então não existia ${ }^{198}$.

Numa perspectiva similar, Carlos Fuentes afirmou que a literatura latinoamericana continuava existindo graças aos escritores exilados como Octavio Paz e Cortázar, que, além de talentosos, tinham uma enorme perspectiva frente a seus países e frente à cultura latino-americana ${ }^{199}$. O crítico uruguaio Rodríguez Monegal defendeu a ideia de que muitos escritores necessitavam do exílio para olhar com certa perspectiva o seu próprio mundo ${ }^{200}$. Por sua vez, García Márquez afirmou que aprendeu a conhecer o continente americano em Paris, pelo grande número de exilados latino-americanos que residiam na capital francesa ${ }^{201}$.

Numa entrevista concedida a Alfonso Tealdo, em 1966, Vargas Llosa afirma: "sou um escritor realista e prefiro o Peru. Porém, não estou disposto a sacrificar a literatura pelo Peru. Por nada. Sei que o exílio é perigoso, que borra a perspectiva, que a pessoa perde contato com o idioma vivo e da rua, porém vou". Na ocasião, o escritor peruano, licenciado da Radio Televisão Francesa, estava de partida para Londres. No artigo "Literatura y exilio" (1968), Vargas Llosa sustenta que a reprovação ou temor quanto ao exílio do escritor, manifestava-se através de dois tipos de percepções: para alguns, o exílio físico poderia debilitar ou falsear a visão do escritor acerca da realidade, devido à falta de contato direto com as idiossincrasias, o idioma e a gente de seu país. Para outros, o assunto tinha uma significação ética, escolher o exílio seria algo imoral, constituiria uma traição à pátria ${ }^{202}$. Na perspectiva do escritor peruano, o contato físico com a própria realidade nacional não "determinava nem os temas, nem o voo imaginativo, nem a

198 GONZÁLEZ BERMEJO, Ernesto. Conversas com Cortázar. Rio de Janeiro: Jorge Zahar, 2002 , p. 17.

${ }^{199}$ FUENTES, Carlos apud RODRÍGUEZ MONEGAL, Emir. "Situación del escritor en América Latina". Mundo Nuevo, Paris, n. 01, julho, 1966, p.11-12.

${ }^{200}$ RODRÍGUEZ MONEGAL, Emir. "Una escritura revolucionária”. Revista Iberoamericana, v. 37, n. 76-77, jul-dez.1971, p.497-506. Disponível em: <http://revista-iberoamericana.pitt.edu. > ${ }^{201}$ GARCÍA MÁRQUEZ, Gabriel apud COSTA, Adriane A. Vidal, op. cit., p.157.

202 VARGAS LLOSA, Mario. [1968]. "Literatura e Exílio". In: Contra vento e maré. Rio de Janeiro: Francisco Alves, 1985, p.145. 
vitalidade da linguagem" ${ }^{, 203}$. Dessa forma, contrariando aqueles que desconfiavam da produção do escritor exilado, Vargas Llosa declara:

[...] Sarmiento escreveu seus melhores ensaios sobre seu país - Facundo e Recuerdos de província - longe da Argentina; ninguém põe em dúvida o caráter profundamente nacional da obra de Martí, quatro quintos dela escritos no desterro; e o realismo de costumes das últimas novelas de Blest Gana, concebidas várias décadas depois de chegar a Paris, é menos fiel à realidade chilena que o dos livros que escreveu em Santiago? Asturias descobriu o mundo mágico de seu país na Europa; os livros mais anedoticamente argentinos de Cortázar foram escritos em Paris $^{204}$.

Os posicionamentos quanto ao exílio e suas razões podiam ser múltiplos, desde razões políticas de fácil compreensão até razões mais secretas e ambíguas. É, sobretudo, o exílio voluntario que se coloca em questionamento, através das noções de universalidade e internacionalismos em oposição ao regionalismo literário. Como ressaltou Adriane Vidal Costa, o exílio, seja este físico ou simbólico, criou e intensificou as redes de comunicação entre intelectuais, ampliando o conhecimento das singularidades de cada região ${ }^{205}$.

\section{4. Macondo "nuestra América"}

A cidade das suas ficções: ele a inventou. E o fez com tanta arte e tanta força persuasiva que essa cidade de fantasia, de nostalgia, de ódio, de rancor e, sobretudo, de palavras, que é a sua, acaba tendo, na memória dos seus leitores, uma predominância que supera, em dramatismo e em cor, a antiquíssima urbe de carne e osso - de pedra e argila, melhor dizendo - que lhe serviu de modelo. A razão de ser da literatura é o protesto, a contradição e a crítica. O escritor tem sido, é e continuará sendo um descontente.

Mario Vargas Llosa

Aracataca, a cidade natal e modelo da ficção de García Márquez, é um elemento fortemente arraigado à memória do escritor colombiano. A cidade imaginária engendrada por García Márquez, em sua vontade totalizadora, nas palavras de Vargas Llosa, produziu tal efeito de verdade, sobre o imaginário, que a Aracataca real é facilmente confundida com Macondo ${ }^{206}$. Ao longo dos anos, não somente Aracataca ganhou ar de Macondo, como toda a América Latina ${ }^{207}$.

\footnotetext{
${ }^{203}$ Ibidem, p. 147

${ }^{204}$ Ibidem, p. 146.

${ }^{205}$ COSTA, Adriane A. Vidal, op. cit., p.155.

${ }^{206}$ VARGAS LLOSA, Mario. A verdade das mentiras. São Paulo: Arx, 2004, p.54.

${ }^{207}$ Em 25 de junho de 2006, foi realizado na cidade de Aracataca, um plebiscito organizado pelo então prefeito da cidade, Pedro Sánchez Rueda, com o intuito de consultar a população sobre a
} 
Para o crítico literário José Miguel Oviedo, Macondo é um “território mágico e americano", onde o tudo e o nada se passam, onde a fantasia de García Márquez emparelha a superstição com a religião estabelecida, e o poder civil com o abuso político. Macondo é o mito latino-americano onde o escritor mostra como a realidade e a fantasia podem se unir para criar um mundo típico com personagens folclóricos, ou indivíduos descomunais, fantásticos com características extraordinárias (a Mama Grande, o coronel Aureliano Buendía, Melquíades, "La Elefanta"), ou personagens com problemas humanos ordinários, que García Márquez enriqueceu com qualidades e defeitos fora do comum. Na apreciação de Miguel Oviedo: "Macondo foi inventada a partir de dados muito concretos de uma zona real da Colômbia (o mundo da costa atlântica, com seus povoados e sonâmbulos), onde a miséria é natural, o calor implacável, a vida calamitosa e a política bárbara"208. Segundo o escritor argentino Enrique Anderson Imbert, Macondo "[...] é a Colômbia e também toda nossa América"209. Para o escritor chileno Luis Harss:

Graças a García Márquez, o lugar mais interessante da Colômbia atual é um povoado tropical chamado Macondo, que não aparece em nenhum mapa. Macondo situado entre dunas e pântanos por um lado e, por outro, a serra impenetrável, é uma cidadezinha costeira tórrida e decadente, como milhares de outras no coração do hemisfério, porém, também muito especial, às vezes, estranha e conhecida [...]. Macondo é mais um ambiente que um lugar, está em todas as partes e em nenhuma. Aqueles que vão até lá empreendem uma viagem interior que faz escala no rosto oculto de um continente ${ }^{210}$.

Para Vargas Llosa, "em Macondo voaram aos pedaços as fronteiras mesquinhas que separam a realidade e a irrealidade, o possível e o impossível". ${ }^{211}$

mudança do nome da cidade para Aracataca-Macondo, em referência à cidade de Cien años de soledad. A medida tinha como intenção aproveitar a fama do nome Macondo para ampliar o turismo e promover o desenvolvimento local. A proposta perdeu por abstenção, o referendo atingiu apenas 3.600 votos dos 7.400 necessários para aprovação do novo nome. (VIEIRA, Felipe de Paula Góis, De Macondo a McOndo: os limites do Real Maravilhoso como discurso de representação da América Latina (1947-1996). 148 f. Dissertação (Mestrado em História) Instituto de Filosofia e Ciências Humanas da Universidade Estadual de Campinas, 2012, p.17).

${ }^{208}$ MIGUEL OVIEDO, José. "Macondo y un territorio mágico y americano". In: BENEDETTI, Mario (org.). Nueve asedios a García Márquez, Santiago de Chile: Editorial Universitaria, 1969, p.89.

${ }^{209}$ IMBERT, Enrique Anderson apud Vieira, Felipe de Paula Góis, op., cit., p. 19.

${ }^{210}$ HARSS, Luis. [1966]. Los nuestros. Buenos Aires: Sudamericana, 1969, p.383-384.

[tradução nossa].

${ }^{211}$ VARGAS LLOSA, Mario. "Garcia Marquez: de Aracataca a Macondo". In: BENEDETTI, Mario (org.). Nueve asedios a García Márquez, Santiago de Chile: Editorial Universitaria, 1969, p.43. 
A seu ver, Macondo representa a América Latina. Nesse sentido, declara o escritor peruano:

A grandeza maior de seu livro [Cien años de soledad] reside, justamente, no fato de que tudo nele - as ações e os cenários, mas também os símbolos, as visões, as feitiçarias, os presságios e os mitos - está profundamente ancorado na realidade da América Latina, dela se nutre e, transfigurando-a, acaba refletindo-a de maneira certeira e implacável ${ }^{212}$.

A transformação de Macondo em expressão simbólica da América Latina foi, assim como a promoção de Cien años de soledad, uma ação efetiva da comunidade intelectual latino-americana. Distintos escritores e críticos literários produziram paralelos entre Macondo e a América Latina, ou entre a história de Cien años de soledad e a história do subcontinente. Macondo tornou-se um território incorporado ao mapa da literatura ocidental, representando, ainda que idilicamente, o desejo de unidade latino-americana da época. O próprio García Márquez contribuiu com esta percepção em algumas de suas declarações. Dessa forma, afirma o escritor colombiano:

\begin{abstract}
A realidade latino-americana tem diferentes aspectos e eu creio que cada um de nós está tratando diferentes aspectos dessa realidade. É nesse sentido que eu creio que o que estamos fazendo é um único romance. [...] Há um nível comum e o dia que encontrarmos como expressar esse nível, escreveremos o romance latinoamericano verdadeiro, o romance total latino-americano, válido em qualquer país da América Latina apesar das diferenças políticas, sociais, econômicas e históricas ${ }^{213}$.
\end{abstract}

Para o autor, os leitores de Cien años de soledad poderiam ser entendidos como uma comunidade "que se vivesse num mesmo pedaço de terra, seria um dos vinte países mais povoados do mundo" ${ }^{214}$. A imagem da América Latina construída por García Márquez tem um entroncamento numa tradição do conto popular, que o autor buscar por diferentes caminhos resgatar e renovar. Os mitos, fábulas e lendas ecoam em Cien años de soledad (1967). Os relatos que García Márquez ouve de sua avó transformaram-se em historietas e fontes anedóticas, que residem numa experiência cujas raízes podem ser encontradas no mundo

${ }^{212}$ VARGAS LLOSA, Mario. [2005]. Dicionário Amoroso da América Latina. Rio de Janeiro: Ediouro, 2006, p.157.

${ }^{213}$ GARCÍA MÁRQUEZ, Gabriel; VARGAS LLOSA, Mario. La novela en América Latina: Diálogo. Lima: C.M. Batres, Universidad Nacional de Ingenieria, 1967, p.38-39.

${ }^{214}$ GARCÍA MÁRQUEZ, Gabriel apud Vieira, Felipe de Paula Góis, op. cit., p. 21. 
ainda folclórico do interior da Colômbia. Conforme assinala Candido, o externo aqui, “importa, não como causa, nem como significado, mas como elemento que desempenha um certo papel na constituição da estrutura, tornando-se, portanto, interno"215. A articulação entre o arcaico e o popular, entre os mitos, lendas, símbolos e histórias universais, possibilitaram que a crítica transforma-se Macondo na metáfora da América Latina. Em Cien años de soledad, o tradicional realismo do romance da terra aparece contaminado pela fábula e pelo mito, impregnado de humor e fantasia, como uma das formas de questionamento, impugnação e repulsa da realidade.

Ao incorporar os mitos, como os das crônicas do "descobrimento" e da passagem bíblica do êxodo, além da oralidade popular, García Márquez reconheceu um universo dispersivo, ambíguo, de associação livre, de incessante invenção que correlaciona ideais, personagens e coisas. A quebra do sistema lógico racional ocidental assume em Cien años de soledad uma temporalidade instável, entrecruzando o passado e o futuro em suas construções imagéticas. Trata-se de um tempo transitório, no qual o elemento temporal atua como (re) construtor do indivíduo, o estar inteiramente em si, em sua solidão. De acordo com Ángel Rama, o grande mérito dos transculturadores - categoria na qual inclui García Márquez - teria sido a descoberta de algo mais que o mito; estes teriam promovido uma passagem dos "mitos literários" ao "pensar mítico"216.

Como observou Karina de Castilho Lucena, se a exploração do novo continente pelos europeus foi a do outro, representada nas crônicas do descobrimento, em Cien años de Soledad a descoberta dos fundadores de Macondo é interior, eles desvendam o próprio continente latino-americano. O descobrimento de Macondo é o descobrimento da América pelos americanos, uma tomada de consciência. É como se García Márquez, ao alegorizar a América Latina em uma cidade imaginária, convidasse os latino-americanos a desvelar o seu território e sua gente ${ }^{217}$. A autora, ao fazer um comparativo entre Cien años de soledad e a passagem bíblica do êxodo - na qual Moisés é guiado e protegido por

${ }^{215}$ CANDIDO, Antonio. Literatura e sociedade: estudos de teoria e história literária. São Paulo: T. A. Queiroz, 2000, p.4.

${ }^{216}$ RAMA, Ángel. Transculturación narrativa en América Latina. $2^{\mathrm{a}}$ ed. Buenos Aires: Edições El Andariego, 2008, p.63-64.

${ }^{217}$ LUCENA. Karina de Castilhos. Macondo: Além da terra firme(Um estudo sobre a cidade imaginária). 122 f. Dissertação (Mestrado em Letras) - Programa de pós-graduação em Letras e Cultura Regional da Universidade de Caxias do Sul - RS, 2008, p.42. 
Deus, ao levar os Hebreus para terra prometida - encontrou alguns paralelos textuais, construídos de forma paródica, a partir da diáspora.

Moisés é a ligação entre o divino e o humano; ele auxilia o povo judeu na fuga da escravidão no Egito, o cativeiro da grande "Babilônia", e recebe os mandamentos que regulamentarão a fé hebraica, exercendo um duplo papel de guia e censor. Há ainda a certeza de que chegarão a uma terra melhor onde serão livres e por isso deverão reverenciar a um Deus único. Munidos da mesma esperança redentora, José Arcádio Buendía perturbado pela presença do fantasma de sua vítima, Prudencio Aguilar - assassinado por ele após uma discussão na qual a hombridade do agressor é posta em dúvida -, reúne sua esposa Úrsula Iguarán, grávida então do primeiro filho do casal, e outros jovens casais que desmontam suas moradas e partem em busca de uma nova terra.

Em Cien años de Soledad não aparece à figura divina que ampara e liberta o povo da tirania. Também, não há a figura divina que oprime e exige devoção, isso ficará a cargo dos déspotas que dominarão a cena política do continente. Todas as ações são vontades humanas; os homens são quem decidem abandonar o passado em busca de um futuro melhor. Tampouco há a certeza de que alcançarão um bom lugar para viver, pelo contrário, eles são movidos pela incerteza. Os personagens de García Márquez estão à margem da bondade divina católica, não há lugar para eles na terra prometida, por isso, têm que construir a sua própria terra, com o pouco que lhes é dado. No entanto, estando à margem da bondade não estão livres da opressão, já que a História cumprirá o papel regulador legado à divindade no texto bíblico. José Arcádio, o Moisés dos fundadores de Macondo, não presenciou a aparição do Senhor, ele é um simples homem que dispõe apenas de sua intuição para conduzir o povo ${ }^{218}$. Após vinte e seis meses percorrendo uma imensa área de matas, serras e pântanos, os precursores da nova comunidade, cansados de tentar encontrar uma saída para o mar e sentindo-se impossibilitados de retornarem, acabam por fundar o povoado de Macondo, em uma região escolhida ao acaso.

O romance de García Márquez se constitui de forma dialógica, situando-se na história e na sociedade. Os personagens constituem seu ser na medida em que se comunicam externa e internamente. $\mathrm{O}$ dialogismo ocorre entre os personagens,

218 Ibidem, p.33-36 
entre o autor e o leitor, e entre diferentes textos (intertextualidade). $\mathrm{O}$ caráter dialógico da literatura pode ser compreendido na afirmação de Vargas Llosa:

a literatura [...], diferentemente da ciência e da técnica, é, foi e continuará sendo, enquanto existir, um desses denominadores comuns da experiência humana, graças ao qual os seres vivos se reconhecem e dialogam, não importa o quão distintas sejam suas ocupações e desígnios vitais, as geografias e as circunstâncias em que existem, e, inclusive, os tempos históricos que determinam seu horizonte ${ }^{219}$.

Nessa dimensão, também, está à proposição de Wolfgang Iser, que ao analisar a relação entre ficção e realidade, ressalta que a ficção comunica algo sobre o real, ela não é a realidade, não porque careça de atributos reais, mas sim porque é capaz de organizar a realidade de tal modo que esta se torna comunicável $^{220}$. O latente entrecruzamento entre a literatura e a história da América Latina, assume em Cien años de soledad, um exemplo pulsante. Diferentes fases da formação cultural latino-americana são mostradas através da saga da família Buendía, em Macondo, servindo como uma espécie de microcosmo, onde se expressa à história de violência e expropriação do continente, primeiro pelos povos ibéricos e, posteriormente, pela exploração de outras nações.

Em princípio, a cidade é constituída como uma aldeia livre de divisões sociais e com algumas riquezas naturais, o local se transforma ao longo do tempo, unindo a presença mítica, os processos de hibridização populacional, guerras pelo poder e as marcas do imperialismo econômico. Tais processos encontram-se particularmente conectados à forma como é concebida a identificação cultural de seus habitantes, expostos nos diferentes períodos da existência da cidade aos diversos deslocamentos, seja nos costumes, nos hábitos ou na organização social do local. Na leitura de Beatriz de Moraes Vieira, a saga de várias gerações da família Buendía, selada pela solidão ao longo de cem anos, revela o viés traumático do processo de urbanização e modernização na América Latina no século XX, marcado por violências, no âmbito econômico, social, político ou simbólico-discursivo.

Segundo Vieira, esse processo gerou duas dinâmicas distintas: de adestramento para o esquecimento nas formações sociais reais e de existência na

\footnotetext{
${ }^{219}$ VARGAS LLOSA, Mario. A verdade das mentiras. São Paulo: Arx, 2004, p.380.

${ }^{220}$ ISER, Wolfgang. O Fictício e o Imaginário: Perspectivas de uma Antropologia Literária. Rio de Janeiro: Eduerj, 1996, p.102.
} 
memória literária, na qual ficou guardado como vestígio simultaneamente histórico e imaginário ${ }^{221}$. Um exemplo é o episódio do "desenvolvimento" de Macondo, trazido pela companhia bananeira, juntamente com as más condições de trabalho e sobrevivência, que trouxe consigo a organização dos trabalhadores, na qual José Arcádio Segundo passa a militar, participando de diversas revoltas e protestos contra a empresa estrangeira. Com a greve dos trabalhadores, ocorreu a intervenção militar que significou o massacre de mais de três mil pessoas. Este episódio em Cien años de soledad tem seu paralelo na realidade colombiana, no massacre da greve de 1928, que ficou gravado na memória de toda a região bananeira. De acordo com a autora, a literatura operou um deslocamento da história para a esfera ficcional de maneira a pensar e tratar a vivência traumática. A seu ver, "ao abrigar em seu seio ficcional e poético os acontecimentos 'inenarráveis' ou malditos, literal ou simbolicamente, e tornar-se sua testemunha" 222 , a literatura transfigurou a realidade, "tornando o texto literário um espaço de luto, lugar da necessária elaboração social da memória, cujos vestígios, decorrentemente, se tornam ao mesmo tempo reais e imaginários, justapondo as (des) ordens simbólica e histórica"223.

De acordo com Antonio Candido, a consciência do subdesenvolvimento, a partir da Segunda Guerra Mundial (especialmente a partir dos anos de 1950) fez com que os intelectuais da América Latina abandonassem a visão eufórica e romântica, através da qual viam suas nações. A partir deste momento, os escritores passaram a formular em suas narrativas questões sobre o estado de pobreza e abandono em que as sociedades se encontravam. Para o autor, "se a realidade social penetra de algum modo no indivíduo, também o indivíduo literário, ou seja, a personagem se torna paulatinamente social, às vezes apesar do próprio autor [...] a influência é recíproca",224.

Para Emil Volek, doutor em Letras Hispânicas e professor do Departamento de Línguas e Literatura da State University, Tempe, Estados Unidos, a realidade de Macondo fora tão graciosa e hilariante, que "fascinou o público estrangeiro, que tomou tudo isto pela realidade latino-americana [...]",

${ }^{221}$ VIEIRA, Beatriz de Moraes. "Cidades literárias, realidades traumáticas". O Olho da História, n. 14, Salvador (BA), junho de 2010, p. 6.

${ }^{222}$ Ibidem, p.5.

${ }^{223}$ Ibidem, p. 9.

${ }^{224}$ CANDIDO, Antonio. "Literatura e Subdesenvolvimento". In: MORENO, César Fernández (coord.). América Latina em sua Literatura, op. cit., p. 369. 
vista no espelho côncavo do "realismo mágico pós-moderno", cuja ênfase estava fortemente arraigada a determinados elementos constitutivos da narrativa. Porém, pouco a pouco a história de Macondo se viu presa nas armadilhas de sua força arquetípica $^{225}$. Macondo tornou-se o macondismo - termo cunhado pelo sociólogo chileno José Joaquín Bruner -, que expressa uma generalizada distorção sobre a América Latina, alimentada por escritores latino-americanos, assim como por certos intelectuais europeus e norte-americanos, tendo por pressuposto a metáfora de que o continente teria fornecido o substrato necessário para a criação do arcabouço ficcional de Macondo. Uma espécie de síndrome de Macondo que, “seria certa atitude de interpretar a América Latina através das 'belas letras' ou, mais exatamente, como produto exato dos relatos que se contam a partir de sua

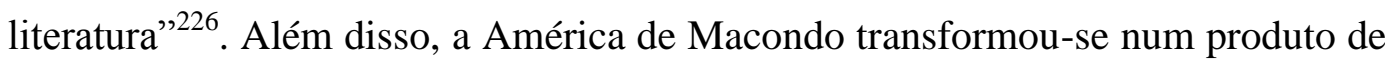
consumo, envolto nas imagens da ancestralidade 227 .

Cabe ressaltar, assim como demonstrado por Felipe de P. Góis Vieira, que essas representações do continente foram fortemente contestadas no início da década de 90, principalmente pelos escritores chilenos Alberto Fuguet e Sergio Gómez que, em 1996, organizaram uma antologia de 17 contos de novos escritores hispano-americanos, intitulada $\mathrm{McOndo}$, publicada em Barcelona. No prólogo-manifesto os organizadores apresentaram contundentes críticas à generalização e ao uso indiscriminado de Macondo, chamando a atenção sobre uma imagem externa da América Latina que já não correspondia a sua realidade social $^{228}$.

O fato é que García Márquez, Vargas Llosa, Alejo Carpentier, Julio Cortázar, Carlos Fuentes, Ángel Rama, José Miguel Oviedo, e tanto outros nomes de escritores e críticos literários, corroboraram na criação de um ideário sobre a significação da América Latina no cenário internacional. Macondo tornou-se seu símbolo, criando seus próprios mitos forjados por uma representação no campo

\footnotetext{
${ }^{225}$ VOLEK, Emil. José Martí, Nuestra (Macondo) América. In: Revista Universum, n. 22, vol. I, 2007, p. 300-317.

${ }^{226}$ Para Brunner, a crença de que esses relatos, em especial aqueles produzidos pelo boom da década de 1960 - sobretudo quando são aclamados pela crítica estrangeira -, são constitutivos da realidade latino-americana ou a expressam literalmente é um efeito real dessa atitude. Para Emil Volek, o macondismo afeta tanto a intelectualidade latino-americana como as academias do "Primeiro Mundo", cujo imaginário ficou ancorado maioritariamente na década de sessenta. (Ibidem, p.314).

${ }^{227} \mathrm{Idem}$.

${ }^{228}$ VIEIRA, Felipe de Paula Góis, op. cit., p.22.
} 
exótico, maravilhoso, mestiço, de governos ditatoriais e corrompidos. Porém, apropriando-se de narrativas orais, Cien años de soledad é também a possibilidade de outra versão, não oficial, das culturas subalternas. Nesse sentido, o romance é também a possibilidade de um futuro diferente do passado.

Para Vargas Llosa, García Márquez inventa mundos a partir de sua rebeldia contra a realidade real. Trata-se de um desacordo com o mundo, que o leva a recriar a realidade em que vive, através de mundos verbais. Sua cidade natal Aracataca, nos termos do escritor peruano, é um de seus "demônios" que irrompem na ficção como Macondo. Para o escritor peruano, "o porquê escreve um romancista está visceralmente mesclado com o que escreve: os demônios de sua vida são os temas de sua obra",229. 


\section{3. \\ Teoria dos "demônios" e seus "obsessores"}

[...] O porquê escreve um romancista está visceralmente mesclado com o que escreve: os demônios de sua vida são os temas de sua obra. Os demônios: atos, pessoas, sonhos, mitos, cuja presença ou cuja ausência, cuja vida ou cuja morte o perseguem na realidade, gravando-se como fogo em sua memória e atormentando seu espírito, convertendo-se nos materiais de sua empresa de reedificação da realidade, nas quais tratará simultaneamente de recuperar e exorcizar, com as palavras e as fantasias no exercício de sua vocação, que nasce e se nutre deles. [...] O processo da criação narrativa é a transformação do demônio em tema, o processo mediante o qual, alguns conteúdos subjetivos convertem-se, graças à linguagem, em elementos objetivos, a mudança de uma experiência individual em experiência universal.

Mario Vargas Llosa

Em 1971, Vargas Llosa publicou o livro Gabriel García Márquez: historia de un deicidio, no qual sustenta a tese de que a vocação do romancista não se elege racionalmente. Esta vocação seria fruto de pressões instintivas e do subconsciente. "Escravo" de sua vocação, o escritor seria um ser afligido por seus "demônios", uma espécie de "obsessão", que pode ser desenvolvida por questões pessoais, históricas ou culturais ${ }^{1}$. Para Vargas Llosa, a vocação do romancista nasce do desacordo de um homem com o mundo, uma insatisfação que o transforma num "deicida", um suplantador de Deus que recria a realidade através de mundos verbais. Assim, a criação narrativa consistiria em transformar a realidade, em extravasar a subjetividade mais restrita - conversão dos "demônios" em temas - para um plano objetivo da realidade ${ }^{2}$.

\footnotetext{
1 Vargas Llosa distingue três tipos de "demônios", a saber: "pessoais" que consiste em experiências que afetaram o escritor em sua vida íntima; "culturais" que incidem sobre as experiências que o escritor sentiu indiretamente, mediante a arte, a música, a mitologia, etc.; e os "históricos" acontecimentos de caráter social que o escritor compartilha com a sociedade. O conceito de "demônios" como impulso inconsciente da criação artística não é uma novidade na história literária. Goethe atribuía aos "demônios" à força interior ou deidade que dirige e inspira o escritor. De acordo com Efraín Kristal, Vargas Llosa parte do conceito goethiano para desenvolver sua própria teoria dos "demônios". (KRISTAL, Efraín. Temptation of the Word. Nashville: Vanderbilt University Press, 1998, p. 3-4).

${ }^{2}$ VARGAS LLOSA, Mario. Gabriel García Márquez: historia de un deicidio. Barcelona: Barral Editores, 1971.p. 91. Em seus trabalhos críticos posteriores, Vargas Llosa utilizou a metáfora do catoblepas, para caracterizar a vocação do escritor e seus temas. O catoblepas é uma criatura impossível, que devora a si própria, começando pelos pés. Este animal mítico aparece em As tentações de Santo Antão, de Gustave Flaubert, e posteriormente, seria recriado por Jorge Luis Borges em $O$ livro dos seres imaginários (1957). Para Vargas Llosa, em um sentido menos material, o escritor também age como um carniceiro de sua própria experiência na busca de matéria-prima para suas narrativas. (VARGAS LLOSA, Mario. [1997]. Cartas a um jovem escritor. Rio de Janeiro: Elsevier, 2006, p. 21).
} 
De acordo com o escritor peruano, após um processo subjetivo e inconsciente, a criação narrativa passaria por uma segunda fase tornando este processo racional. Ou seja, é numa segunda fase da criação que o escritor "exorciza" seus "demônios" dotando-os de forma, através de métodos e estratégias narrativas que resultam o romance. A matéria subjetiva converte-se, portanto, em temas concretos, influxos objetivos e universais, onde o escritor assume a responsabilidade por sua obra e seu êxito. Na teoria dos "demônios", Vargas Llosa põe em relevo a relação intrínseca do que nomeia como "realidade real" e "realidade fictícia", cuja primeira corresponde ao plano objetivo concreto, "existente e natural do mundo e do ser humano em geral", e a segunda ao mundo verbal próprio da criação, composto pelos planos imaginário, milagroso e fantástico.

Na entrevista concedida a Leoncio Reynaldo Trinidad, em 1971, ao falar do livro García Márquez: historia de un deicidio, Vargas Llosa diz: "É um tratado sobre a vocação do romancista, as fontes da ficção e, em especial, as relações entre literatura e realidade. É um livro que se pergunta de que forma a literatura é alimentada pela realidade e, a inversa, de que forma a literatura influi na realidade"3 . O ensaio sobre a obra do escritor colombiano García Márquez é fruto da tese de doutorado de Vargas Llosa, apresentada em 1971, na Universidade Complutense de Madrid com o título García Márquez: lengua y estructura de su obra narrativa. Apesar da teoria dos "demônios" ter sido desenvolvida de modo sistemático neste ensaio, o referencial metodológico, assim como os objetivos da investigação, possui rastro em outra pesquisa acadêmica de Vargas Llosa. Trata-se de sua monografia, apresentada na Universidade Nacional Mayor de San Marcos, em 1958, intitulada Bases para una interpretación de Rubén Darío. Nesse texto, Vargas Llosa abordou o complexo universo de Rubén Darío através do dado biográfico, da relação entre vida e obra, com o intuito de esclarecer a índole da vocação literária do poeta nicaraguense. O que interessava ao autor era fixar os momentos disparadores da iniciação artística de Darío, as vivências e leituras que contribuíram com o exercício de sua vocação ${ }^{4}$. Podemos dizer que nas duas investigações acadêmicas de Vargas Llosa encontra-se um modus operandi que

\footnotetext{
${ }^{3}$ REYNALDO TRINIDAD, Leoncio. ¡Quiero volver a Cuba!. In: COAGUILA, Jorge (comp.) Mario Vargas Llosa Entrevistas escogidas. Lima: Fondo Editorial Cultura Peruana, 2004, p.77.

${ }^{4}$ Esta monografia foi publicada como livro, em 2001.
} 
intenta ressaltar os processos subjetivos que originariam a vocação literária. Esta é uma das noções presentes em artigos, discursos, entrevistas e cartas, ao longo das décadas de sessenta e setenta, na qual o escritor peruano sustenta sua compreensão de literatura e do papel político-social do escritor.

As preocupações teóricas, particularmente sobre o romance, acompanharam o trabalho intelectual e ficcional de Vargas Llosa. Segundo o crítico peruano José Miguel Oviedo, a existência de uma estação crítica no itinerário imaginativo de Vargas Llosa pode ser considerada como fruto de sua atividade acadêmica em algumas universidades da América e da Europa (King's College de Londres, Universidade de Porto Rico, Washington State University, etc.); ou como fruto remanescente do conjunto de leituras, notas, artigos, crônicas, prólogos, polêmicas e vários escritos que vão pautando e forjando sua vida profissional, com seus particulares gostos e aversões, suas aberturas e seu confinamento; porém, sobretudo, é a manifestação teórica que surge de sua própria experiência narrativa ${ }^{5}$.

Algumas noções centrais no modo como Vargas Llosa percebe o papel do escritor-intelectual e a função político-social da literatura estiveram presente em sua formulação da teoria dos "demônios", mas não circunscritas ao livro García Márquez: historia de un deicidio. Ao longo das décadas de sessenta e setenta, o escritor peruano manifestou em artigos, discursos e entrevistas sua subjetividade crítica nas formas como emprega os conceitos de rebeldia, liberdade e obsessão, elementos chaves em sua crítica literária. Nesse período, em que para além dos princípios estéticos estavam em pauta os propósitos político-ideológicos do texto, pensar a literatura era também pensar os modos de existência político-social no continente. Assim, Vargas Llosa ao elaborar sua compreensão da criação narrativa está também formulando seus posicionamentos políticos, a sentença inversa, também é válida.

Um dos aspectos predominantes na Teoria dos "demônios" é a rebeldia como categoria da vocação literária. No artigo "Sebastián Salazar Bondy y la vocación del escritor en el Perú" (1966), publicado na Revista Peruana de Cultura. O autor declara:

\footnotetext{
${ }^{5}$ MIGUEL OVIEDO, José. [1970]. Mario Vargas Llosa: la invención de una realidad. Barcelona: Seix Barral. 1982, p.341.
} 
É verdade que todo escritor é um rebelde, um inconformado com o mundo em que vive, mas esta rebeldia íntima que precipita a vocação literária é de natureza muito diversa. Muitas vezes a insatisfação que leva um homem a opor realidades verbais à realidade objetiva escapa à sua razão; quase sempre o poeta, o escritor é incapaz de explicar as origens de seu inconformismo profundo, cujas raízes se perdem num trauma infantil ignorado, num conflito familiar de aparência intranscendente, num drama pessoal que parecia superado. A esta rebeldia obscura, a este protesto inconsciente e singular que é uma vocação literária superpõe-se no Peru quase sempre uma outra, de caráter social, que não é raiz, mas fruto desta vocação ${ }^{6}$.

Neste texto, em que ressalta os elementos que conjugam o gesto literário, Vargas Llosa realizou uma espécie de denúncia da situação dos escritoresintelectuais na América Latina, tomando como referencial o Peru. A situação que alude refere-se à exploração econômica, ao analfabetismo e a ausência de políticas culturais por parte dos governantes e interesse das elites. No discurso intitulado "La literatura és fuego", proferido em Caracas ao receber o Prêmio Rómulo Gallegos, em 1967, o escritor peruano enunciou o signo de toda uma nova situação da literatura na América Latina, baseada no compromisso do escritor, ressaltando de forma visceral sua compreensão da função-social da literatura. Segundo Vargas Llosa:

\begin{abstract}
Ninguém que esteja satisfeito é capaz de escrever, ninguém que esteja de acordo, reconciliado com a realidade, cometeria o ambicioso desatino de inventar realidades verbais. A vocação literária nasce do desacordo de um homem com o mundo, da intuição de deficiências, vazios e escórias à sua volta. A literatura é uma forma de insurreição permanente e não admite camisas-de-força. Todas as tentativas destinadas a dobrar sua natureza airada e indócil fracassarão. A literatura pode morrer, mas jamais será conformista ${ }^{7}$.
\end{abstract}

O discurso de Vargas Llosa pode ser compreendido como um posicionamento crítico diante da doutrina do realismo socialista. Como podemos observar, tanto no artigo, de 1966, como no discurso, de 1967, Vargas Llosa desenvolve um tipo de argumentação sobre a vocação do escritor e a natureza da literatura que estão amplamente discutidos em sua teoria dos "demônios" no ensaio sobre a obra de Gabriel García Márquez, em 1971. Nestes textos poder-seia dizer que se encontram os princípios estéticos e ideológicos do escritor peruano, assim como os modelos que persegue ou vivência em sua própria

\footnotetext{
${ }^{6}$ VARGAS LLOSA, Mario. [1966]. "Sebastián Salazar Bondy e a Vocação do Escritor no Peru". In: Contra Vento e Maré. Rio de Janeiro: Francisco Alves, 1985, p.136.

${ }^{7}$ VARGAS LLOSA, Mario. [1967]. "A Literatura é Fogo". In: Contra Vento e Maré. Rio de Janeiro: Francisco Alves, 1985, p.136.
} 
narrativa. Mas, não podemos resumir sua formulação ao campo da autocrítica, pois trata-se de uma teoria que se desenvolve na relação com outros referencias teóricos. Autores como Malraux, Flaubert, Faulkner, Victor Hugo, Hemingway, Alejandro Dumas e Martorell, são declarados de maneira geral pelo próprio Vargas Llosa como influências culturais em seu exercício da técnica e estratégia narrativa - ou "demônios culturais" para utilizamos o termo vargallosiano - por sua vez, autores como Sartre e Camus serão influências culturais importantes em sua compreensão da função social da literatura e do compromisso do escritor ${ }^{8}$.

O pensamento crítico de Vargas Llosa foi construído partindo dos diálogos e atravessamentos com outros escritores, filósofos e críticos. Embora, duas questões chamem a atenção neste ponto: o primeiro deles é o fato de Vargas Llosa ter declarado que nunca projetou elaborar uma teoria literária de corte científico, partindo de sua própria experiência como escritor para formular suas argumentações; o segundo é, por vezes, um desacordo com o horizonte interpretativo latino-americano, o que pode ser percebido na ausência referencial de nomes ou conceitos correntes na crítica literária na América Latina da época. Sobre este último, analisaremos com maior profundidade no capítulo IV.

Neste capítulo nos interessa analisar o conteúdo da teoria dos "demônios" e do livro Gabriel García Márquez: historia de un deicidio (1971), observando seus intercâmbios conceituais, assim como seus afastamentos. Isso equivale dizer, os conflitos e convergências que fazem com que Vargas Llosa elabore uma teoria própria, partindo de sua experiência ou desejo como narrador. Em primeiro lugar, recuperamos a relação de Vargas Llosa com o pensamento de Jean-Paul Sartre, seguido por uma análise específica das zonas de contato e conflito na teoria dos “demônios". Em segundo, mostraremos a relação dos argumentos de tal teoria com o pensamento de Sigmund Freud em suas análises sobre o fazer criativo. E, por fim, examinamos a compreensão de Vargas Llosa a respeito do que chama de "romance total", recuperando alguns de seus escritos, mas, principalmente, partindo de sua análise sobre Cien años de Soledad (1967) de García Márquez. Portanto, nosso intuito é mostrar como e em que condições estas leituras estão

\footnotetext{
${ }^{8}$ Em García Márquez: historia de un deicidio (1971), resulta curioso constatar que entre os demônios culturais de García Márquez elencado pelo escritor peruano, encontra-se toda a plêiade dos escritores que Vargas Llosa reconhece (ou reconhecerá posteriormente), como suas próprias influências culturais.
} 
presentes na teoria dos "demônios" e os deslocamentos operados por Vargas Llosa.

\section{1.}

\section{Diálogos com Sartre: os "demônios" e a liberdade como questão}

Segundo Vargas Llosa, seu primeiro encontro com a obra de Jean-Paul Sartre ocorreu no verão de 1952, quando trabalhava como redator em um periódico. De acordo com o autor, a leitura dos textos de Sartre - O Muro (1939), A Náusea (1938), a trilogia Os caminhos da liberdade (1945-1949); e as peças de teatro As Moscas (1943), Huis clos (1944), A prostituta respeitosa (1946), As mãos sujas (1948) - fizeram com que no início dos anos cinquenta, ele descobrisse a literatura moderna ${ }^{9}$. Mas foi em 1953, quando ingressou na Universidad Nacional Mayor de San Marcos onde estudou direito e literatura, que teve o encontro decisivo com o pensamento do filósofo francês, através da leitura do ensaio Que é a literatura?(1947) ${ }^{10}$.

Como vimos no capítulo I, entre as décadas de cinquenta e sessenta, o pensamento de Sartre configurou-se como uma importante influência para os intelectuais latino-americanos, uma espécie de "consciência moral" radicada na função político-social da literatura e no compromisso (engagement) do escritor. Segundo Vargas Llosa, sua experimentação literária ocorreu numa época em que o engajamento e o descomprometimento eram inconcebíveis. Na leitura do escritor peruano, a teoria do compromisso de Sartre consistia "em assumir a época em que se vivia, não as consignas de um partido; em evitar a gratuidade e a irresponsabilidade na hora de escrever, mas não em crer que a função da literatura podia ser a de divulgar certos dogmas, ou converter-se em pura propaganda" $" 11$.

A Revolução Cubana é o acontecimento que marca a entrada da América Latina na modernidade tardia, impactando radicalmente o modo como se pensava e se operacionalizava a literatura no subcontinente. O engajamento do escritor, segundo a concepção sartreana, fazia todo o sentido neste momento, pois

\footnotetext{
9 VARGAS LLOSA, Mario. [1980]. "O Mandarim". In: Contra vento e maré. Rio de Janeiro: Francisco Alves, 1985, p. 387.

${ }^{10}$ VARGAS LLOSA, Mario. [1978]. "Sartre, vinte anos depois". In: Contra vento e maré. Rio de Janeiro: Francisco Alves, 1985, p. 321.

${ }^{11}$ VARGAS LLOSA, Mario. [1980]. “O Mandarim”, p.392.
} 
creditava à literatura um grande poder de transformação social. Para Sartre, a palavra enquanto ação seria capaz de alterar as coisas no mundo, além disso, permitiria ao homem a tomada de consciência de si mesmo, possibilitando-o compreender sua universalidade como projeto em construção, baseado em escolhas ${ }^{12}$.

Em Que é a literatura?, Sartre defendeu categoricamente a possibilidade de se pensar a arte, principalmente a literatura engajada, afirmando que ela pode e deve servir a sociedade. Trata-se de um ensaio de circunstâncias, escrito em 1947, resultado da junção de quatro ensaios publicados inicialmente na revista Les Temps Modernes, logo após a Segunda Guerra Mundial. Para Sartre, a literatura é posicionamento no mundo e o prosador é um homem que escolheu determinado modo de ação secundária, que se poderia chamar de ação por desvendamento, assim, cada palavra tem consequências e cada silêncio também. A cada palavra, o escritor engaja-se um pouco mais no mundo, ao mesmo tempo passa a emergir dele um pouco mais já que o ultrapassa na direção do porvir ${ }^{13}$. Segundo o filósofo francês, “o escritor 'engajado' sabe que a palavra é ação: sabe que desvendar é mudar e que não se pode desvendar senão tencionando mudar"14.

Os primeiros romances de Vargas Llosa estão atravessados pela concepção filosófica de Sartre, revelando personagens em situação com suas angústias e fracassos, além de uma grande preocupação com desvendamento da sociedade peruana. Em La ciudad y los perros (1963), o primeiro romance de Vargas Llosa, as diferentes nuances do homem revelam posicionamentos que são flexibilizados a partir de suas escolhas. $\mathrm{O}$ romance transcorre em dois momentos distintos: o primeiro, no ambiente fechado do Colégio Militar Leoncio Prado, num universo juvenil; o segundo, a vida adulta na cidade.

\footnotetext{
${ }^{12}$ Em O Existencialismo é um Humanismo, Sartre definiu sua percepção do homem enquanto "projeto": "O homem é, inicialmente, um projeto que se vive enquanto sujeito, e não como um musgo, um fungo ou uma couve-flor; nada existe de inteligível sob o céu e o homem será, antes de mais nada, o que ele tiver projetado ser. Não o que vai querer ser. Pois o que entendemos ordinariamente por querer é uma decisão consciente que, para a maior parte de nós, é posterior ao que fizemos efetivamente de nós mesmos. Posso querer aderir a um partido, escrever um livro, casar-me, tudo isto é apenas uma manifestação de uma escolha mais original, mais espontânea do que aquilo que se chama vontade". SARTRE. Jean-Paul. O Existencialismo é um Humanismo. $4^{\mathrm{a}}$ ed. Petrópolis, RJ: Vozes (Vozes de bolso), 2014, p. 19-20.

${ }^{13}$ SARTRE, Jean-Paul. Que é a literatura?. Petrópolis, RJ: Vozes, 2005. (Coleção Textos Filosóficos), p.28-29.

${ }^{14}$ Ibidem, p.29.
} 
De acordo com Vargas Llosa, o Colégio Militar Leoncio Prado, de Lima, era uma espécie de prisão juvenil, onde não se esperava "nada de bom dos cadetes que lá estudavam"15. No colégio, os cadetes eram submetidos a uma educação militarizada, de disciplina absolutamente vertical e de cunho machista. Neste ambiente, cria-se um sistema de vida e hierarquização, regida por proibições oficiais, castigos e códigos de conduta. Paralelo ao modelo oficial de hierarquias e proibições engendra-se um modelo de violência exercida pelos próprios alunos, numa espécie de desafio aos regulamentos. $\mathrm{O}$ romance tece a história num movimento pendular que leva a ação no Leoncio Prado à cidade de Lima, onde as dualidades e contrastes, as frustrações, a solidão e angústia, presente na vida juvenil de formação dos cadetes, segue a vida dos adultos na cidade, abrindo um abismo entre o desejo e a conduta humana.

O romance se inicia com o roubo das questões de um exame de Química, pelo cadete Porfirio Cava sob as ordens do Círculo - grupo formando por alguns alunos que impõem o terror e a violência aos demais - liderado pelo Jaguar. O delito é descoberto, e os alunos são proibidos de deixar o colégio. O cadete chamado de Esclavo (Ricardo Arana) por seus companheiros, afetado por não poder ver Teresa (moça pela qual está apaixonado) denuncia Cava pelo crime, que é expulso da instituição. Sem saber quem é o delator, os alunos começam a suspeitar uns dos outros, o mais obcecado em descobrir o possível infiltrado no Círculo é o Jaguar, cuja liderança exige o segredo e o cumprimento de um "código de honra".

Em uma manobra militar, Esclavo recebe um tiro na cabeça e morre pouco depois, Jaguar passa a ser o principal suspeito. O colégio temeroso pelas consequências do escândalo que o caso poderia provocar estabelece uma versão oficial, tratando o caso como acidente. Alberto (conhecido por todos como o Poeta) rompe com o pacto de silêncio que o une ao Círculo e denuncia o crime de Jaguar ao tenente Gamboa. Nesse momento, o pacto de silêncio passa a incluir

${ }^{15}$ VARGAS LLOSA, Mario. [1963]. La ciudad y los perros. $3^{\mathrm{a}}$ ed. Barcelona: Seix Barral, 1985, p.179. Segundo Vargas Llosa, sua vocação como escritor, surgiu como uma rebelião contra a autoridade paterna. Seu pai, figura que conheceu apenas quando tinha 11 anos de idade, considerava a atividade da escrita como sintoma de fraqueza, associando-a a homossexualidade, além de entender a literatura como condução ao fracasso, pois esta atividade não lhe renderia seu sustento. Assim, aos 14 anos de idade, seu pai o matriculou no Colégio Militar Leoncio Prado para que desenvolvesse a disciplina e afirmasse sua "masculinidade". Sobre a relação do escritor peruano com o pai, ver: VARGAS LLOSA, Mario. [1993]. Peixe na água: memórias. São Paulo: Companhia das Letras, 1994, p.13-34. 
também as autoridades do colégio, mesmo com a denúncia as investigações não são reabertas. O próprio Alberto se vê impedido de sustentar as acusações, pois passa a sofrer ameaças dos oficiais, que o intimidam com a possibilidade de mostrar a seus pais os romances pornográficos que escrevia e vendia a seus companheiros $^{16}$. Alberto cede e Gamboa também, pois o apoio inicial à denúncia do aluno lhe custa uma promoção. No epílogo do romance, que segue a saída dos cadetes do colégio, os protagonistas começam a se "readaptar" a vida civil. Gamboa ocupa um posto em uma guarnição longínqua na serra, Alberto reinicia sua vida burguesa no bairro de Miraflores com novas amizades e o Jaguar torna-se empregado de um banco e casa-se com Teresa.

Como observou Ángel Rama, não existe oposição rígida de militares e estudantes, como dois mundos hostis. O primeiro repete o segundo, com as mesmas organizações internas, com as mesmas mentiras e as mesmas verdades contraditórias, com idêntica dualidade dentro dos personagens contrastada com a descrição das ações públicas e os monólogos interiores. Desse modo, Rama percebeu a influência da concepção sartreana no romance, que revela as diferentes máscaras ou defesas do homem, compostas na medida em que se desenvolve a ação exterior ${ }^{17}$. Segundo José Miguel Oviedo, a obra cabe comodamente nas margens do realismo, trabalhando com uma realidade concreta (um colégio específico chamado Leoncio Prado, um determinado sistema educativo do exército peruano, uma atitude mental comum às famílias humildes e pequeno burguesas, e um fracionamento social que se percebe até mesmo na rivalidade dos bairros: Miraflores, Lince, Callao), a tal ponto que em algumas leituras mais superficiais o romance é percebido como um mero ataque ao colégio ${ }^{18}$. Para Miguel Oviedo, a obra contém uma inevitável denúncia, contudo, não se trata de uma transposição da matéria bruta, de casos vividos pelo autor em seus tempos de cadete no Leoncio Prado; melhor se enquadraria num "realismo crítico" que

\footnotetext{
${ }^{16}$ Em sua autobiografia, Vargas Llosa confessa que na época de estudante no colégio Leoncio Prado escrevia "romancezinhos eróticos" por divertimento ou para vender a seus companheiros, e que havia descrito alguns episódios semelhantes no romance La ciudad y los perros. VARGAS LLOSA, Mario. Peixe na água: memórias, op. cit., p.115.

${ }^{17}$ RAMA, Ángel. "De como sobreviene lo humano". Marcha, Montevidéu, n. 1194, fev.1964, p.29.

${ }^{18}$ Segundo José Miguel Oviedo, ofendidos com a publicação de La ciudad y los perros, alguns generais queimaram cerca de mil exemplares da primeira edição no pátio do colégio Leoncio Prado, e tentaram desprestigiar o autor com informações de sua época estudantil. (MIGUEL OVIEDO, José. [1970]. Mario Vargas Llosa: la invención de una realidad. Barcelona: Seix Barral. 1982, p.22).
} 
incorpora traços do mundo objetivo, filtrados pelo imaginário, que transposto artisticamente adquire a forma romanesca ${ }^{19}$. Em suma, o romance elabora a violência como geradora da própria violência. Dessa forma, Vargas Llosa desvenda a sociedade peruana em suas contradições, numa visão da sociedade como um vasto inferno coletivo, semelhante ao universo do Leoncio Prado.

Os conflitos, do indivíduo consigo mesmo e com a sociedade, são temas de outros romances de Vargas Llosa, entre os quais podemos citar: La casa verde (1966), onde aparecerá também a dicotomia entre um Peru urbano, com os problemas do subdesenvolvimento e a selva peruana, com um tempo histórico distinto. Ou ainda, Conversación en La Catedral (1969), romance ambientado num período de grande insatisfação política, no qual os personagens da trama apresentam ligações distintas com a ditadura de Manuel Odría (1948 a 1956), delineando um painel da corrupção e dos efeitos que uma ditadura pode exercer sobre os âmbitos da vida familiar, profissional, política e intelectual ${ }^{20}$. Em testemunho sobre a criação dos seus personagens, disse Vargas Llosa:

Não quero mostrar meus personagens como simples resultantes de forças exteriores, senão assinalar como conseguem sobreviver dentro das coordenadas nas quais se encontram incorporados. Eles elegem sempre entre alternativas e são responsáveis por seus destinos. Meus romances estão baseados em certas pessoas e coisas que eu vivi e em como essas pessoas superaram as determinações entre as quais viviam ${ }^{21}$.

O desafio desigual entre os personagens e as circunstâncias, como observou José Miguel Oviedo, autorizaram com que alguns críticos assinalassem certo determinismo na narrativa de Vargas Llosa, limitando seus personagens às forças do meio. Assim, Rosa Boldori de Baldussi qualificou La ciudad y los perros como o "romance do determinismo ambiental" 22 . E, o chileno Luis Harss argumentou que na obra de Vargas Llosa, as individualidades dos personagens se perdem na densidade do ambiente: "não há pessoas, senão mais bem estados de consciência que se manifestam somente através das situações que as definem"23. Neste aspecto, concordamos com a leitura de Miguel Oviedo, que sem negar a existência

\footnotetext{
${ }^{19}$ Ibidem, p.95-96.

${ }^{20}$ A Ditadura de Manuel Odría pode ser considera um dos "demônios históricos" de Vargas Llosa. O escritor peruano explorou amplamente esta questão em sua autobiografia El pez en el agua (1993).

${ }^{21}$ VARGAS LLOSA, Mario apud MIGUEL OVIEDO, José, op. cit., p.112-113. [tradução nossa].

${ }^{22}$ BOLDORI, Rosa apud MIGUEL OVIEDO, José, op. cit., p.111.

${ }^{23}$ HARSS, Luis apud MIGUEL OVIEDO, José, op. cit., p.110.
} 
do caráter determinista, aproxima a composição dos personagens de Vargas Llosa a sua leitura sartreana.

Segundo José Miguel Oviedo, Vargas Llosa não nega aos seus personagens a liberdade; se em suas narrações eles aparecem como arrastados por forças superiores, isto se deve a suas escolhas. Muitas vezes, os personagens aceitam seu próprio destino, não como um fato, ou falta de opção, senão pelo esgotamento destas opções. A liberdade que para Sartre é a condição fundante do sujeito e elemento de sua angústia, nos personagens de Vargas Llosa aparece como categoria fundamental. Os personagens são "escravos" de sua liberdade, elegendo sua posição e seu destino não como "quietismo", mas como ato livre diante das pressões perturbadoras de um fato definitivo, no qual Vargas Llosa os submete a fim de observar seu comportamento, colocando-os na eminência do que Sartre chama de situação ${ }^{24}$. A situação é um conceito dinâmico que expressa a tensão entre o dado e o projeto humano, e que revela o caráter finito da liberdade: existe no ato, não como um absoluto. Segundo Miguel Oviedo, em sua leitura de Sartre, toda a liberdade é sempre uma liberdade situada. Isso quer dizer que nossa liberdade reflete a contingência do ser, pois este opera projetando-se em um mundo que ele não criou, que não elegeu (um lugar, uma soma de circunstâncias, a presença do passado ou da morte). Esta teoria da liberdade em situação nega, precisamente, o determinismo e o fatalismo; afirmando a ideia do homem como um projeto de ser que se inventa voluntariamente, o ser existe quando atua e exerce sua liberdade contra a dureza das condições gerais que a realidade lhe impõe $\mathrm{e}^{25}$.

Em meados dos anos sessenta, a opinião de Vargas Llosa a respeito da perspectiva literária e filosófica de Sartre sofre uma mudança. A grande decepção do escritor peruano com o filósofo francês ocorreu em 1964, em torno da entrevista concedida por Sartre ao Le Monde, pouco tempo depois de ter recusado o Prêmio Nobel de literatura. O que chocou Vargas Llosa foram as declarações de Sartre a respeito da situação do escritor nos países em desenvolvimento, na qual dizia "que diante de uma criança que morre de fome, La nausée não serve de nada, não vale nada", e que os escritores deveriam, em última instância, renunciar

\footnotetext{
${ }^{24}$ MIGUEL OVIEDO, José, op. cit., p.112.

${ }^{25}$ Ibidem, p.115.
} 
momentaneamente à literatura para servir melhor à sua sociedade ${ }^{26}$. Para o escritor peruano, existia um abismo entre estas declarações, insinuando que a melhor maneira para um escritor ajudar os seus semelhantes é, em certos casos, renunciar a escrever, e as páginas de Que é a literatura?, quando Sartre afirmou a importância do desenvolvimento da literatura para a sociedade de modo geral ${ }^{27}$. Segundo Vargas Llosa, ao ler a reportagem sua sensação foi de ter sido traído ${ }^{28}$.

Em 1978, o escritor peruano publicou o artigo "Sartre, veinte años después", revelando uma nova leitura sobre o ensaio Que é a literatura? Vargas Llosa comparou as proposições de Sartre ao realismo socialista, concordando que ambos tinham mais similaridade do que diferenças. Nesta revisão, o escritor peruano considerou que o compromisso sartreano pede à literatura uma justificação social, assim como o realismo socialista. A diferença é que, para Sartre, o escritor só pode efetuar sua missão fora do Partido Comunista, já que este deixou de atuar revolucionariamente para se submeter à URSS, mas tanto para Sartre como para o realismo socialista, a atualidade é uma obrigação moral, entendendo a literatura em última instância como um "jornalismo mais bem escrito". Por isso, Sartre considerou o jornalismo como o "gênero literário de nosso tempo"29.

Apesar de Vargas Llosa ter se distanciado do pensamento político e literário de Sartre - principalmente, em fins da década de setenta -, é possível identificar alguns rastros mais perduráveis do filósofo francês no pensamento de

${ }^{26}$ VARGAS LLOSA, Mario. [1964]. "Os Outros Contra Sartre". In: Contra vento e maré. Rio de Janeiro: Francisco Alves, 1985, p. 39.

${ }^{27}$ As declarações de Sartre tiveram repercussões imediatas na América Latina, principalmente, entre aqueles escritores que se declaravam influenciados por ele, como é o caso de Vargas Llosa e Ernesto Sabato, que publicaram textos polemizando as declarações de Sartre. Também, em 1964, Sartre publicou Les Mots, texto autobiográfico no qual revisa sua trajetória intelectual e suas concepções acerca da literatura e a situação do escritor. Nesse texto, Sartre declara: "foi nos livros que encontrei o universo: assimilado, classificado, rotulado, pensado e ainda temível; confundi a desordem de minhas experiências livrescas com o curso aventuroso dos acontecimentos reais. Daí veio esse idealismo de que gastei trinta anos para me desfazer" (1984, p.33). Este idealismo, diz respeito à confiança absoluta na palavra escrita. Em sua revisão, Sartre considerou como impotente a situação do escritor, pois objetivamente a literatura não é capaz de grandes transformações num plano concreto. Acrescenta que, todavia, libertar-se dos erros não é abdicar de escrever, "pois é só o que resta a ser feito": "Desinvesti, mas não me evadi: escrevo sempre. Que outra coisa fazer? [...] É meu hábito e meu ofício. Durante muito tempo tomei a pena como espada: agora conheço a nossa impotência. Não importa: faço e farei livros; são necessários; sempre servem, apesar de tudo". (SARTRE, Jean-Paul. [1964]. As palavras. Rio de Janeiro: Nova Fronteira, 1984, p.182).

${ }^{28}$ VARGAS LLOSA, Mario. [1964]. "Os outros contra Sartre". In: Contra vento e maré. Rio de Janeiro: Francisco Alves, 1985, p.39.

${ }^{29}$ VARGAS LLOSA, Mario. [1978]. "Sartre, vinte anos depois". In: Contra vento e maré. Rio de Janeiro: Francisco Alves, 1985, p. 323-324. 
Vargas Llosa. ${ }^{30}$ Quiçá, o mais importante tenha sido uma atitude geral perante a literatura como uma produção artística de fundamental importância para a sociedade, e o sentido de liberdade que deve exigir o escritor-intelectual para o exercício da sua vocação. A relação de Vargas Llosa com o pensamento e a obra de Sartre não é uma novidade no que se refere às pesquisas sobre a narrativa ficcional ou a trajetória intelectual do escritor peruano. É o próprio escritor quem declara esta influência, na qual poderíamos empregar a mesma metáfora que mobiliza em sua teoria dos "demônios". Nesse sentido, Sartre seria um dos "demônios culturais" de Vargas Llosa. Porém, não se trata de uma presença óbvia na teoria dos "demônios", permanecendo como um campo a ser investigado. Por isso, nossa intenção é buscar os referentes do pensamento de Sartre na teoria dos "demônios" do escritor peruano, estabelecendo os diálogos - entenda-se convergência e conflito - em sua construção teórica. Mais que as influências, nos interessa os transbordamentos. Sendo assim, consideramos esta leitura como um rizoma, com suas camadas, modulações e reelaborações ${ }^{31}$.

Um dos entrelaçamentos mais evidentes diz respeito ao que Vargas Llosa considera como a função político-social da literatura, que está na base da teoria dos "demônios". Para o escritor peruano, a literatura é uma forma de insurreição permanente e não admite "camisas-de-força", todas as tentativas "destinadas a dobrar sua natureza airada e indócil fracassarão. A literatura pode morrer, mas jamais será conformista" ${ }^{, 2}$. Para o autor, a literatura contribui ao "aperfeiçoamento humano, impedindo o marasmo espiritual, a autossatisfação, a imobilidade, a paralisia humana, o amolecimento intelectual ou moral" ${ }^{, 33}$. Na perspectiva de Vargas Llosa, a liberdade é condição sine qua non para que exista a

${ }^{30}$ Analisaremos as mudanças no pensamento político-ideológico de Vargas Llosa no capítulo III.

31 Adotamos o conceito de rizoma elaborado por Deleuze e Guatarri. Para os autores o conhecimento se forma a partir de encontros; produzir é também apropriar-se de outros pensamentos, pois não se cria a partir do nada. A criatividade se evidencia no modo como se trabalha as ideias já produzidas. De acordo com eles: "Um rizoma não começa nem conclui, ele se encontra sempre no meio, entre as coisas, inter-ser, intermezzo. A árvore é filiação, mas o rizoma é aliança, unicamente aliança. A árvore impõe o verbo 'ser', mas o rizoma tem como tecido a conjunção 'e... e... e...' Há nesta conjunção força suficiente para sacudir e desenraizar o verbo ser. Para onde vai você? De onde você vem? Aonde quer chegar? São questões inúteis. [...] Entre as coisas não designa uma correlação localizável que vai de uma para outra e reciprocamente, mas uma direção perpendicular, um movimento transversal que as carrega uma e outra, riacho sem início nem fim, que rói suas duas margens e adquire velocidade no meio". DELEUZE, Gilles; GUATTARI, Félix. Mil platôs: capitalismo e esquizofrenia. Vol. 1. $1^{\mathrm{a}}$ ed. Rio de janeiro: Editora 34, 1995, p.36.

32 VARGAS LLOSA, Mario. [1967]. "A Literatura é fogo". In: Contra vento e maré. Rio de Janeiro: Francisco Alves, 1985, p.136.

${ }^{33}$ Idem. 
literatura. A liberdade é o eixo da filosofia sartreana, cujo postulado básico é de que a existência precede a essência, ou seja, a liberdade é fundante do sujeito, não havendo nada que pré-determine o ser do homem. Desde que vem ao mundo, o homem está inteiramente entregue a si mesmo, é um projeto permanente que vai se realizando segundo a maneira como ele escolhe entre as opções diárias e múltiplas que deve enfrentar. É na ação livre que o homem escolhe seu ser, que se constrói enquanto sujeito, produto de sua liberdade, que não é uma conquista, mas, sua condição.

O home é sempre livre para escolher - a abstenção, também, é uma escolha - e por isso é responsável por todos os erros e acertos que compõem a sua vida, de sua miséria e de sua felicidade. O homem não é uma essência imutável (uma "alma") que precede e continua a sua trajetória carnal, é uma existência que, à medida que se faz no tempo e na história, vai constituindo sua essência própria. Ou seja, existem os homens, não a "natureza humana". Na leitura de Vargas Llosa do conceito de liberdade em Sartre, ainda que o homem seja o dono de seu destino não significa, certamente, que todos os seres podem escolher sua vida em igualdade de condição. Isso implica um leque de alternativas totalmente diferentes para cada um, em todos os campos da experiência. Mas, em todos os casos, "mesmo no dos mais desamparados, no das piores vítimas, sempre é possível escolher entre comportamentos diferentes, e cada escolha importa um projeto humano geral, uma concepção da sociedade, uma moral"34.

Para Sartre, em Que é a literatura?, a prosa se distingue de outras obras de arte porque trata a palavra como instrumento significante, e, portanto, referencia aquilo que está fora dela. Ao se referir a algo que não é ela, a palavra revela o significante, transforma aquilo que nomeia. Segundo Thana Mara de Souza, é, pois, por esse poder de nomear e transformar da palavra que Sartre afirmou que a prosa é engajada. O engajamento seria, portanto, "o desvelamento do mundo por meio das palavras, o modo como o escritor decidiu revelar tal situação e se calar sobre outra, e o modo como o leitor se viu refletido (por meio de um "espelho" crítico) e agiu perante a sua nova imagem"35. O papel da prosa seria justamente o

\footnotetext{
${ }^{34}$ VARGAS LLOSA, Mario. [1980]. “O Mandarim”. In: Contra vento e maré. Rio de Janeiro: Francisco Alves, 1985, p.391.

${ }^{35}$ SOUZA, Thana Mara. Da estética à ética: uma análise compreensiva das obras literárias de Sartre e Malraux. 335 f. Tese (Doutorado em Filosofia) - Programa de Pós-Graduação do
} 
de revelar pela significação e comunicação, esse engajamento que somos. De acordo Sartre:

Cada uma de nossas percepções é acompanhada da consciência de que a realidade humana é "desvendante"; isto quer dizer que através dela "há" o ser, ou ainda que o homem é o meio pelo qual as coisas se manifestam; é nossa presença no mundo que multiplica as relações, [...] a cada um de nossos atos, o mundo nos revela uma face nova. Mas se sabemos que somos os detectadores do ser, sabemos também que não somos seus produtores. [...] Assim, à nossa certeza interior de sermos "desvendantes" se junta aquela de sermos inessencias em relação à coisa desvendada ${ }^{36}$.

Neste sentido, um dos principais motivos da criação artística seria a necessidade de nos sentirmos essenciais em relação ao mundo. Para o filósofo francês, os aspectos desvendados, uma vez fixados num texto, estreitam as relações, introduzindo ordem onde não havia nenhuma, impondo a unidade de espírito à diversidade das coisas, portanto, o escritor possui a consciência de produzi-los, sente-se essencial em relação a sua criação. Mas, o objeto criado escapa ao seu criador, pois não se pode desvendar e produzir ao mesmo tempo. A criação passa para o inessencial em relação à atividade criadora. $\mathrm{O}$ objeto criado está sempre inacabado aos olhos de seu criador, "parece estar sempre em suspenso, sempre se pode alterar uma linha, uma palavra, um colorido"37.

Dessa forma, há no escritor certa insatisfação ou angústia quanto sua própria obra. Neste ponto, Vargas Llosa parece concordar com Sartre. Tomemos, como exemplo, sua declaração a respeito da publicação de seu primeiro conto Los jefes (1959): “quando apareceu o livro na Espanha, eu já não gostava; não me sentia solidário com ele" ${ }^{38}$. Em Gabriel García Marquez: historia de un deicido (1971), Vargas Llosa evidenciou esta insatisfação do escritor ao abordar os procedimentos narrativos e as atitudes de García Márquez diante de sua obra. Segundo o escritor peruano, García Márquez ao finalizar Los funerales de la Mamá Grande (1962), optou por guardar o manuscrito no "fundo de uma maleta",

Departamento de Filosofia da Faculdade de Filosofia, Letras e Ciências Humanas da Universidade de São Paulo, 2008, p.3.

${ }^{36}$ SARTRE, Jean-Paul. Que é a literatura?, op. cit., p.38.

${ }^{37}$ Ibidem, p.39.

${ }^{38}$ A publicação de Los jefes (1959) na Espanha, rendeu a Vargas Llosa o prêmio Leopoldo Alas. O prêmio teve escassa ressonância fora da Espanha. Os cinco contos reunidos no livro são fruto do período considerado como iniciação literária do escritor peruano, entre seus 16 e 18 anos. (Rodríguez Monegal, Emir. "Madurez de Vargas Llosa". Mundo Nuevo, Paris, n. 3, set.1966, p.64). 
pois não estava convencido de sua obra. Essa relação está presente também no que Vargas Llosa denominou como "silêncio e autocrítica" de García Márquez, período de 1961 a 1965, que antecede a escrita de Cien años de Soledad ${ }^{39}$.

Se a concepção de literatura de Vargas Llosa vai ao encontro da concepção sartreana, ela parte deste entre para produzir outros modos de percepção. Na medida em que o escritor peruano concebe a vocação literária como uma ardente convicção, sugerindo a imagem da literatura como um parasita que corre nas entranhas do criador (metaforizando-a como uma solitária), percebe a vocação do escritor como uma possessão quase mórbida, onde o ato de escrever se cumpre com certo mal-estar porque a literatura exige do escritor o todo pelo todo. Para Vargas Llosa, ao eleger a literatura como forma de vida, o escritor opta por um destino marginal, não havendo para ele lugar nem direitos, porém, o escritor responde com fogo, atribuindo-se todos os direitos que a sociedade lhe nega e que ele resgata para a literatura ${ }^{40}$. Isto significa de algum modo negar a total liberdade do escritor no processo de criação, pois o escritor é tomado por uma obsessão que pode ser consciente ou não, mas é de todo irracional.

$\mathrm{Na}$ teoria dos "demônios", o foco da insatisfação do escritor recai sobre o princípio da vocação literária, que nasce do desacordo do homem com o mundo em que vive, recriando realidade através de mundos verbais. Segundo Vargas Llosa:

Escrever romances é um ato de rebelião contra a realidade, contra Deus, contra a criação de Deus que é a realidade. É uma tentativa de correção, mudança ou abolição da realidade real, de sua substituição pela realidade fictícia que o romance cria. Este é um dissidente: cria vida ilusória, cria mundos verbais porque não aceita a vida e o mundo como são (ou como acredita que são). A raiz de sua vocação é um sentimento de insatisfação contra a vida; cada romance é um deicídio secreto, um assassinato simbólico da realidade ${ }^{41}$.

A insatisfação com a "realidade real" está presente na intencionalidade que Sartre atribuiu ao desvendamento produzido pelo escritor, pois este ao desvendar

${ }^{39}$ VARGAS LLOSA, Mario. Gabriel García Márquez: historia de un deicidio. Barcelona: Barral Editores, 1971, p.76-79.

${ }^{40}$ VARGAS LLOSA, Mario. [1966]. "Sebastián Salazar Bondy e a Vocação do Escritor no Peru". In: Contra vento e maré. Rio de Janeiro: Francisco Alves, 1985, p.90-115. Esta ideia do escritor como um ser marginal na sociedade, será repetida pelo autor em textos diversos como no discurso "A literatura é fogo" (1967) e em Gabriel García Márquez: historia de un deicídio (1971). A parábola da solitária é repetida por Vargas Llosa como analogia a vocação do escritor em Cartas a un joven novelista (1997).

${ }^{41}$ VARGAS LLOSA, Mario. Gabriel García Márquez: historia de un deicidio, op. cit., p.88. [tradução nossa]. 
a situação, assim o faz por uma intencionalidade de mudança. Nesse sentido, o imaginário da obra de arte parte do real e o mantêm como pano de fundo, é um afastar-se do real, apenas para mais compreensivamente voltar-se para ele. Esta relação entre o "mundo real” e o "mundo imaginário ou fictício" Vargas Llosa evocou em diferentes textos de sua crítica. Para o escritor peruano, o movimento de distanciamento do real numa obra imaginária jamais esquece o mundo. A criação narrativa é a reelaboração do caos do real, produzindo sobre este um pensamento crítico. Dessa forma, ao analisar o romance e os procedimentos de sua criação, Vargas Llosa afirma que o romancista realiza constantes "saqueios da realidade", colocando a matéria real a serviço do imaginário ${ }^{42}$. Porém, o mundo narrado não é o mundo vivido, relacionando-se com este, não de um modo determinista, mas numa espécie de mediação por via dos inventos de um autor. Concepção que se reflete nos métodos de trabalho de Vargas Llosa, que constrói seus romances a partir do que ele chama de "magma", um esboço sobre personagens, situações, vivências, e pequenas passagens da vida real, que antecede a criação estrutural e formal do romance.

A diferença substancial da teoria dos "demônios" com a concepção sartreana de literatura, está no que Vargas Llosa denomina como "demônios", elementos que, irracionalmente, provocam o desejo de ruptura com o mundo objetivo. Segundo o escritor peruano, "a ruptura não é o resultado de um fato único, a tragédia de um instante, senão um lento, solapado processo, o balanço de uma complexa soma de experiências negativas da realidade"43. Neste sentido, segundo sua proposição, a única maneira de averiguar a origem da vocação do romancista é um rigoroso enfrentamento da vida e da obra do escritor. A revelação desta vocação estaria nos pontos em que ambas se confundem ${ }^{44}$. O

\footnotetext{
${ }^{42}$ Ibidem, p.107-110.

${ }^{43}$ Ibidem, p.89.

${ }^{44}$ O método utilizado por Vargas Llosa em Gabriel García Márquez: historia de un deicidio é construído por uma análise biográfica e psicológica dos temas da narrativa. Esta metodologia já havia sido empregada inclusive por Sartre no ensaio Saint Genet: comédien et martyr (1952) e, posteriormente, no ensaio sobre Flaubert, L'Idiot de la famille (1972). Conforme Daniela Ribeiro Schneider, Sartre teceu críticas contundentes à forma mecanicista como as biografias, em geral, são elaboradas, na medida em que realizam uma narrativa histórica feita por fora, sustentando-se em acontecimentos exteriores e em alusões aos grandes ícones explicativos de nossa época: hereditariedade, meio, educação, etc. O método biográfico em Sartre pode ser compreendido enquanto totalização. Busca-se através da compreensão do indivíduo imerso em situação, esclarecer as condições materiais, antropológicas e sociológicas, chegando às dimensões subjetivas e psicológicas que tornaram o indivíduo o que ele é. (SCHNEIDER, Daniela Ribeiro. "O Método Biográfico em Sartre: contribuições do Existencialismo para a Psicologia". Estudos e
} 
processo de criação narrativa seria, então, a transformação dos "demônios" em "temas", processo que converte, graças à linguagem, alguns conteúdos subjetivos em elementos objetivos, ou seja, a mudança de uma experiência individual em experiência universal.

Em Sartre a metáfora de um deicida seria impossível, na medida em que o filósofo parte da intuição que Deus não existe, se existisse, estaria em situação em relação ao homem, pois este nasce indeterminado, ele é o único responsável pela sua existência e deve suportar o peso de sua liberdade ${ }^{45}$. Escolha e responsabilidade estão na concepção sartreana unidas num grande arco, que supõe a fatalidade da liberdade, mesmo quando os resultados objetivos das ações não correspondam às intenções subjetivas. Segundo Franklin Leopoldo e Silva, a fatalidade da liberdade em Sartre

está em que ela é um poder que o homem possui e ao qual ao mesmo tempo está irremediavelmente submetido na medida em que não pode se furtar a exercê-lo. [...] O sujeito não é livre em si mesmo, porque nenhum sujeito existe em si como coisa ou como entidade metafísica, já que a subjetividade nada mais é do que o movimento de autoconstituição de si mesma, num processo totalizante de identificação destinado a nunca se completar ${ }^{46}$.

Nesse sentido, Sartre idealizou a necessidade do escritor estar vinculado a sua época, porque a liberdade é antes de tudo a experiência da possibilidade enquanto compromisso com o futuro. Para Leopoldo e Silva, “este é o significado concreto da situação, como hora e como lugar da liberdade, mas ao mesmo tempo como escolha absoluta, isto é, como invenção de si e de seu tempo"47. A literatura tem então uma função: falar ao outro, de modo que produza atos de significação que o levem a conhecer-se e a conhecer o seu contexto. Essa função é social, cumprida por via da liberdade; pelo apelo da liberdade do escritor à liberdade do leitor, o que não significa tornar a literatura um instrumento ideológico.

pesquisa em Psicologia, UERJ, RJ, ano 8, n.2, $1^{\circ}$ semestre de 2008, p.297). Sartre no livro $O$ Ser e o Nada: ensaio de ontologia fenomenológica (1943) estabeleceu os parâmetros da análise compreendida por uma psicologia existencialista do homem, que se difere do postulado da psique inconsciente de Freud. No que se refere à teoria dos "demônios", Vargas Llosa parece interagir com a irrealização do real e a realização do desejo, através de uma correção da realidade insatisfatória, assim como propôs Freud em suas análises do fazer artístico, no qual analisaremos na terceira seção deste capítulo.

${ }^{45}$ SARTRE, Jean-Paul. Que é a literatura?, op. cit., p. 29.

${ }^{46}$ LEOPOLDO E SILVA, Franklin. "Literatura e experiência histórica em Sartre: o engajamento". In: Revista Doispontos. Curitiba, São Carlos, vol. 3, n. 2, outubro, 2006, p.75. [grifos do autor].

${ }^{47}$ Ibidem, p.76. 
$\mathrm{Na}$ negatividade da literatura, assim como propõe Leopoldo e Silva, podemos perceber a literatura engajada em Sartre, como algo que está ligado ao entendimento da arte como liberdade de negar o existente por via da intencionalidade imaginante da consciência. De acordo com o autor:

[...] é preciso explicitar essa negatividade ou esse poder negador, pois ele pode ser entendido como uma irresponsabilidade inerente ao artista. Isso ocorreu no caso da negatividade romântica pela qual o gênio se isola do mundo; por uma literatura governada pelo princípio da arte pela arte, como em Flaubert; pela negatividade da palavra que recusa a transitividade significativa e se encerra na sua pura materialidade, como em certas tendências modernas da poesia; ou pela contestação surrealista da ordem da significação. Para Sartre, em nenhum desses casos a negatividade aparece como instrumento de engajamento, pois em nenhum deles há um compromisso verdadeiro com a negação. São exercícios solipsistas nos quais a literatura trai a sua função transitiva. Ou são meios de que o artista se serve para separar a liberdade da responsabilidade ${ }^{48}$.

O engajamento deve ser pensado a partir de uma experiência negativa da transitividade, onde não estão dadas as condições em que a coletividade, na forma de público leitor, pode responder com liberdade à liberdade do escritor. Assim, a recepção da obra é compreendida através da expressão do indivíduo e da coletividade, numa retomada constante de si mesmo como subjetividade social ${ }^{49}$. A negatividade da literatura é um ponto em comum entre Sartre e Vargas Llosa, uma criação que nega o existente, atravessada por uma inconformidade com a realidade. Mas, na teoria dos "demônios", Vargas Llosa assume que esta relação se conecta a uma expressão psicológica do escritor. Poderíamos dizer que Sartre pergunta-se, principalmente, Para quem se escreve? ressaltando o processo de interação entre escritor-leitor, no qual assume como um compromisso no que se refere à produção de significado da obra, o que chama de pacto de generosidade. Por sua vez, Vargas Llosa preocupa-se, ao menos na teoria dos "demônios", em responder a questão Por que se escreve?, perpassando os aspectos subjetivos e psicologizantes da origem da vocação literária. O escritor peruano enfatiza a irracionalidade da vocação do romancista, um processo no qual o homem se submente a sua vocação "mais por pressões instintivas e subconscientes que por uma decisão racional" ${ }^{, 50}$. Para Vargas Llosa, a grande questão em torno dos

\footnotetext{
${ }^{48}$ LEOPOLDO E SILVA, Franklin, op. cit., p.76-77.

${ }^{49}$ Ibidem, p. 73.

${ }^{50}$ VARGAS LLOSA, Mario. Gabriel García Márquez: historia de un deicidio, p.95.
} 
"demônios" que afligem o escritor está relacionada aos "temas" da narrativa.

Segundo ele, um

[...] homem não elege seus "demônios": ocorrem-lhe certas coisas, algumas o fizeram tanto que o levam, loucamente, a negar a realidade e a querer substituí-la. Essas "coisas" que estão na origem de sua vocação, serão, também, seu estímulo, suas fontes; a matéria a partir da qual essa vocação trabalhará. Não se trata, desde logo, nem no caso de García Márquez nem no de nenhum outro escritor, de reduzir o arranque e o alimento da vocação a uma experiência única: outras, no transcurso do tempo, complementam, corrigem, substituem a inicial. [... $]^{51}$.

Para o escritor peruano, nenhum romancista se liberta dessa "fixação", o peso do movimento de ruptura com a realidade irá transpassar toda a sua práxis. Mas,

[...] o exercício de sua vocação é um paliativo, não um remédio. Nunca triunfará em seu vertiginoso, quase sempre inconsciente designo de substituir: cada romance será um fracasso, cada conto uma desilusão. Porém, dessas derrotas sistemáticas sacará novas forças, e outra vez o intentará, fracassará e seguirá escrevendo, em busca da vitória impossível. Sua vocação será um simulacro contínuo graças ao qual poderá viver ${ }^{52}$.

Como dissemos, tanto para Vargas Llosa como para Sartre a angústia e a insatisfação são elementos caracterizadores da vocação literária, embora adquiram desenvolvimentos distintos em ambas as perspectivas. Enfim, cabe ressaltar que, Sartre considerou que na prosa o prazer estético seria um acréscimo e a forma uma eleição do escritor, que somente depois de inventada passaria por um julgamento. Segundo Sartre:

Ninguém é escritor por haver decidido dizer certas coisas, mas por haver decidido dizê-las de determinado modo. E o estilo, decerto, é o que determina o valor da prosa. Mas ele deve passar despercebido. Já que as palavras são transparentes e o olhar as atravessa, seria absurdo introduzir vidros opacos entre elas. A beleza aqui é apenas uma força suave e insensível. Sobre uma tela, ela explode de imediato; num livro ela se esconde, age por persuasão como o charme de uma voz ou de um rosto; não constrange, mas predispõe sem que se perceba, e acreditamos ceder a argumentos quando na verdade estamos sendo solicitados por um encanto que não se vê $[\ldots]^{53}$.

Para Vargas Llosa, este "encanto que não se vê", corresponde à construção narrativa, ao emprego das técnicas responsáveis por conceder ao romance o que chama de poder de persuasão. A seu ver, quanto mais verossímil e autêntico, quanto mais invisível for à presença do escritor, mais o romance gera este tipo de

\footnotetext{
${ }_{51}^{51}$ Ibidem, p.99. [tradução nossa].

${ }^{52}$ Ibidem, p.99-100. [tradução nossa].

${ }^{53}$ SARTRE, Jean-Paul. Que é a literatura?, op. cit.,p.30.
} 
efeito. Segundo o escritor peruano, o romance "é a verdade das mentiras"54. Daí que Vargas Llosa tenha grande admiração por Gustave Flaubert, que em meados do século XIX, esmerou-se no procedimento técnico baseado na impassibilité, na objetividade da ausência do autor, conscientemente distinguido do narrador; o escritor peruano dedicou o livro La orgía perpetua: Flaubert y Madame Bovary (1975) a esta admiração que por vezes chegou a ser visceral.

\section{2. O discurso do inconsciente: Freud e Vargas Llosa}

Ao anunciarmos uma aproximação da teoria dos "demônios" de Vargas Llosa com o pensamento de Sigmund Freud, não pretendemos circunscrever à psicanálise freudiana um modelo estrito para interpretação desta teoria, mas como uma possibilidade de atravessamento, relacionada aos aspectos psicológicos da criação literária na qual anuncia o escritor peruano ${ }^{55}$. É o próprio escritor quem declara que sua construção imagética da vocação do romancista e o conteúdo de sua teoria dialogam com as investigações de Freud, embora não especifique suas conexões $^{56}$. Nosso intuito é analisar em que circunstâncias Vargas Llosa se aproxima de Freud ao formular sua teoria dos "demônios". Uma aproximação que ao mesmo tempo cumpre o papel de distanciamento de Vargas Llosa de um elemento central da concepção sartreana: a formulação da total responsabilidade do homem sobre sua psique.

Jean Paul-Sartre rejeita a ideia de causas inconscientes dos fatos psíquicos, uma vez que para ele todos os aspectos de nossas vidas mentais são intencionais, partícipes da escolha e, por isso, de nossa inteira responsabilidade. Dessa forma, o filósofo francês critica o empirismo da metodologia psicanalítica, na qual Freud está inserido, por esta retirar a responsabilidade do indivíduo ao invocar a ação de

\footnotetext{
${ }^{54}$ Sobre a relação entre a técnica e o poder de persuasão na concepção de Vargas Llosa, ver: VARGAS LLOSA, Mario. [1997]. Cartas a um jovem escritor. Rio de Janeiro: Elsevier, 2006.

${ }^{55}$ Um exemplo é a tese de doutorado de Petter Jonsson que, aproxima a cosmovisão e a construção narrativa de Vargas Llosa de duas correntes da psicanálise: Freud e Lacan, ver: JONSSON, Petter. Tres lecturas de las novelas de Mario Vargas Llosa: Interpretación psicoanalítica de la producción novelesca de un autor. Suécia: Lunds Universitet, Språk-och Litteraturcentrum Spanska. Série Études Romanes de Lund 86, 2009. Disponível em: <https://lucris.lub.lu.se/ws/files/3073763/1468204.pdf.>

${ }^{56}$ VARGAS LLOSA, Mario. [1972]. "O Regresso de Satã". In: Contra vento e maré. Rio de Janeiro: Francisco Alves, 1985, p.180.
} 
uma força subconsciente e estados mentais inconscientes. ${ }^{57}$ Ao abordar a diferença entre a psicanálise empírica e sua proposta de uma psicanálise existencial, Sartre declara em O ser e o nada (1943):

Com efeito, elas diferem na medida em que a psicanálise empírica determinou seu próprio irredutível, em vez de deixá-lo revelar-se por si mesmo irredutível [...]. A libido ou a vontade de poder constituem, de fato, um resíduo psicobiológico que não é evidente por si mesmo e não nos surge como devendo ser o termo irredutível da investigação. Em última instância, a experiência estabelece que o fundamento dos complexos é esta libido ou esta vontade de poder, e tais resultados da investigação empírica são completamente contingentes e não chegam a convencer: nada nos impede de conceber a priori uma "realidade humana" que não se expressasse pela vontade de poder e cuja libido não constituísse o projeto originário e indiferenciado. Ao contrário, a escolha à qual irá remontar-se a psicanálise existencial, precisamente por ser escolha, denuncia sua contingência originária, já que a contingência da escolha é o inverso de sua liberdade. Além disso, na medida em que se fundamenta sobre a falta de ser, concebida como caráter fundamental do ser, tal escolha recebe legitimação como escolha, e sabemos que não precisamos ir mais longe ${ }^{58}$.

Vargas Llosa na teoria dos "demônios" aproxima-se, ainda que com reservas, mais do discurso do inconsciente freudiano do que da psicanálise existencial, embora em sua polêmica com Ángel Rama tenha mencionado o método analítico de Sartre como perspectiva dos estudos sobre o escritor e sua obra $^{59}$. A psicanálise é uma maneira de compreender a psique do homem, revelando os processos inconscientes de sua identidade. Vargas Llosa ao examinar a criação narrativa de García Márquez, assim o fez ao relacionar os momentos da vida do escritor que foram determinantes na construção dos temas de sua narrativa.

A atenção do escritor peruano está voltada para a explicação das origens da criação literária e da vocação do romancista. Para Vargas Llosa, o material primário da criação narrativa poderia ser encontrado nos "demônios" ou obsessões

\footnotetext{
${ }^{57}$ Em O ser e o nada, Sartre considerou que "o psicólogo empírico, definindo o homem por seus desejos, permanece vítima da ilusão substancialista (substantialiste). Encara o desejo como existente no homem a título de "conteúdo" de sua consciência, e supõe que o sentido do desejo é inerente ao próprio desejo. Evita, assim, tudo que poderia evocar a ideia de uma transcendência". Em seguida diz: "outro erro que mantém profundas conexões com o primeiro, consiste em considerar terminada a investigação psicológica uma vez alcançada o conjunto concreto dos desejos empíricos. Assim, um homem seria definido pelo feixe de tendências que a observação empírica pode estabelecer". SARTRE, Jean-Paul. O ser e o nada: Ensaio de ontologia fenomenológica. $15^{\text {a }}$ ed. Petrópolis, RJ: Vozes, 2007, p 682.

${ }^{58}$ Ibidem, p.699.

${ }^{59}$ VARGAS LLOSA, Mario. [1972]. "O Regresso de Satâ". In: Contra vento e maré. Rio de Janeiro: Francisco Alves, 1985, p.180. Analisaremos a polêmica entre Ángel Rama e Vargas Llosa no capítulo IV.
} 
do escritor. Sigmund Freud também se deteve em compreender de onde o escritor criativo retira seu material, interessando-se pela natureza da criação imaginativa e pelo modo como o escritor consegue impressionar-nos despertando em nós emoções inesperadas. Em Escritores criativos e devaneio (1907-1908), Freud indaga: "Será que deveríamos procurar já na infância os primeiros traços de atividade imaginativa?". Para ele, a visão de mundo dos escritores e das crianças são presenças próximas, pois ambos criam um mundo próprio. De acordo com Freud:

Seria errado supor que a criança não leva esse mundo a sério; ao contrário, leva muito a sério a sua brincadeira e dispende na mesma muita emoção. A antítese de brincar não é o que é sério, mas o que é real. Apesar de toda a emoção com que a criança catexiza seu mundo de brinquedo, ela o distingue perfeitamente da realidade, e gosta de ligar seus objetos e situações imaginados às coisas visíveis e tangíveis do mundo real. Essa conexão é tudo o que diferencia o 'brincar' infantil do "fantasiar"

O autor supõe que o escritor criativo passa pelo mesmo processo que a criança quando brinca: cria um mundo de fantasia que leva muito a sério investindo uma grande carga de afeto, embora mantenha nítida a separação entre o mundo de fantasia e a realidade. A linguagem é a categoria responsável por preservar essa relação entre o brincar infantil e a criação poética. Para Freud:

A irrealidade do mundo imaginativo do escritor tem, porém, consequências importantes para a técnica de sua arte, pois muita coisa que, se fosse real, não causaria prazer, pode proporcioná-lo como jogo de fantasia, e muitos excitamentos que em si são realmente penosos, podem tornar-se uma fonte de prazer para os ouvintes e espectadores na representação da obra de um escritor ${ }^{61}$.

Ao crescer, os indivíduos parariam de brincar e aparentemente renunciariam a este prazer infantil, mas, na realidade, segundo Freud, esse prazer não é verdadeiramente renunciado, pois para o homem é extremamente difícil abdicar de um prazer já experimentado. Dessa forma, ocorre uma substituição e não renúncia: "a criança em crescimento, quando pára de brincar, só abdica do elo com os objetos reais; em vez de brincar, ela agora fantasia. Constrói castelos no ar

60 Para Freud, catexizar é investir um objeto com energia do instinto. FREUD, Sigmund. "Escritores Criativos e Devaneio". In "Gadiva” de Jensen e outros trabalhos. Edição Standard Brasileira das Obras Psicológicas Completas de Sigmund Freud - Vol. IX. Rio de Janeiro: Imago Ed., 1986, p.79. [grifo nosso].

${ }^{61}$ Idem. 
e cria o que chamamos de devaneios" ${ }^{\prime 62}$. A construção de fantasias é comum à maioria das pessoas, mas são menos fáceis de observar do que o brincar das crianças, pois o adulto envergonha-se de suas fantasias, escondendo-as das outras pessoas. Freud chegou a identificar algumas características do fantasiar, atribuindo as forças motivadoras das fantasias aos desejos insatisfeitos, que variam de acordo com o sexo, o caráter e as circunstâncias da pessoa que fantasia, dividindo-se naturalmente em dois grupos principais: ou são desejos ambiciosos, que se destinam a elevar a personalidade do sujeito; ou são desejos eróticos. Toda a fantasia seria, portanto, a realização de um desejo, uma correção da realidade insatisfatória, onde o passado, o presente e o futuro são entrelaçados pelo fio do desejo que os une. Nesse sentido, a fantasia, para Freud, mantém com o tempo uma relação flutuante, onde os três momentos são abrangido pela ideação. Segundo ele, o

trabalho mental vincula-se a uma impressão atual, a alguma ocasião motivadora no presente que foi capaz de despertar um dos desejos principais do sujeito. Retrocede à lembrança de uma experiência anterior (geralmente da infância) na qual esse desejo foi realizado, criando uma situação referente ao futuro que representa a realização do desejo. O que se cria então é um devaneio ou fantasia, que encerra traços de sua origem a partir da ocasião que o provocou e a partir da lembrança ${ }^{63}$.

Os devaneios são formas de reconfigurar o mundo externo, construindo um novo laço do sujeito com a realidade/mundo e o outro, são expressões dos diversos estados do ser, de suas experiências vividas. Quando as fantasias se tornam exageradamente profusas e poderosas, estão criadas as condições para o desencadeamento da neurose ou da psicose. Ao que concerne o escritor criativo, para Freud, este é um ser capaz de provocar em nós um grande prazer quando relata o que julgamos ser seus próprios devaneios, diferentemente de um indivíduo comum que ao nos comunica seus devaneios, causa repulsa ou indiferença. Freud considera que a verdadeira arte poética está na suplantação deste sentimento de repulsa, o que o escritor criativo faz de duas maneiras: suavizando "o caráter de seus devaneios egoístas por meio de alterações e disfarces" e nos subornando "com o prazer puramente formal, isto é, estético, que nos oferece na apresentação de suas fantasias" ${ }^{\prime 64}$.

\footnotetext{
${ }^{62}$ Idem.

${ }^{63}$ Ibidem, p.81.

${ }^{64}$ Ibidem, p. 84.
} 
Freud distinguiu os escritores, separando-os entre aqueles que como os antigos poetas egípcios e trágicos, utilizam temas preexistentes como os mitos, lendas e contos de fadas, daqueles que parecem criar o próprio material. A seu ver, é muito provável que os mitos, por exemplo, sejam vestígios distorcidos de fantasias plenas de desejos de nações inteiras, "os sonhos seculares da humanidade jovem" ${ }^{\text {,65 }}$. A ênfase colocada nas lembranças infantis da vida do escritor deriva-se basicamente da suposição de que a obra literária, como o devaneio, é uma continuação, ou um substituto, do que foi o brincar infantil. Ainda que numa versão preliminar da análise sobre o fazer poético e artístico, em Escritores criativos e devaneio, Freud lançou as bases que estão presentes em textos posteriores, como no ensaio Leonardo da Vinci e uma lembrança da sua infância (1910), que se baseia na recordação comunicada por Leonardo da Vinci sobre sua infância para explicar o quadro Sant'Ana, a Virgem e o Menino.

Para Freud, o imaginário e a fantasia são possibilidades de buscar referências no simbólico para a criação da realidade. No texto $A$ perda da realidade na neurose e na psicose (1924), Freud desenvolve a questão da negação da realidade. Segundo ele, toda a neurose perturba de algum modo à relação do doente com a realidade, incutindo nele uma espécie de fuga da vida real. O afrouxamento da relação com a realidade é consequência de um segundo estágio na formação da neurose, o primeiro seria o $E u$, que a serviço da realidade efetua a repressão de um impulso instintual. Sendo assim, a neurose seria o resultado de uma repressão malograda do instinto ${ }^{66}$.

A negação da realidade é conduzida pelas mesmas tendências na neurose e na psicose, nos dois casos ela serve às aspirações de poder do $I d$, que não se deixa coagir pela realidade. Tanto a neurose como a psicose são expressões da rebeldia do Id contra o mundo externo, de seu desprazer ou de sua incapacidade de adequar-se à necessidade real, é uma reconstrução, um desvio a norma. Neurose e psicose diferenciam-se muito mais na primeira reação, que as introduz, do que na tentativa de reparação que lhe segue. No resultado final: na neurose uma porção da realidade é evitada mediante a fuga, enquanto na psicose é remodelada. A diferença aguda entre neurose e psicose, no entanto, é diminuída pelo fato de

\footnotetext{
${ }^{65}$ Ibidem, p.84.

${ }^{66}$ FREUD, Sigmund. "A perda da realidade na neurose e na psicose". In: $O E u$ e $o I D$, "Autobiografia" e outros textos [1923-1925]. Obras Completas - Vol. XVI. São Paulo: Companhia das Letras, 2014, p.194-195.
} 
também na neurose haver tentativas de substituir a realidade indesejada por outra mais conforme aos desejos. Segundo Freud, estes mesmo traços podem ser encontrados em indivíduos "sadios":

Chamamos de normal ou "sadio" o comportamento que une certos traços de ambas as reações, que nega a realidade tão pouco como a neurose, mas se empenha em alterá-la como a psicose. Essa conduta adequada aos fins, normal, leva naturalmente a um trabalho efetuado no mundo exterior, e não se limita, como na psicose, a mudanças internas; já não é autoplástica, mas aloplástica ${ }^{67}$.

Isso é possibilitado pela existência de um mundo da fantasia, de um âmbito que foi separado do mundo externo real quando da introdução do princípio da realidade. O fantasiar carrega em si uma relação entre o desejo e a castração, revelando uma série de representações simbólicas. Neste campo, Freud investigando a linguagem do sonho e sua intepretação, atribuiu à mesma estrutura a criação artística, pensada segundo a função de representação de fantasias e devaneios ${ }^{68}$. Sobre a relação entre as fantasias e os sonhos, Freud diz que: "nossos sonhos noturnos nada mais são do que fantasias" e, que a linguagem "com sua inigualável sabedoria, há muito lançou luz sobre a natureza básica dos sonhos, denominando de 'devaneios' as etéreas criações da fantasia"69. Desse modo, o objeto literário situa-se no espaço de realização imaginária do desejo, onde o prazer estético provém de seu conteúdo ou pela sua forma, na qual o leitor encontra prazer por identificação, quanto ao personagem ou alguma temática abordada; ou ainda, por uma relação do brincar, tendo a obra um efeito intermediário.

Numa análise autobiográfica, publicada em 1925, Freud declarou que o que a psicanálise pôde fazer, em relação à criação literária, foi tomar as inter-relações das impressões de vida, as vivências casuais e as obras do artista e construir sua

\footnotetext{
${ }^{67}$ Ibidem, p.196. [grifo nosso].

${ }^{68}$ Freud escreveu o livro A interpretação dos sonhos, publicado em 1900, no qual formula a tese de que o sonho é a realização (disfarçada) de um desejo (reprimido). Uma formação de compromisso entre as exigências de um impulso instintual reprimido e a resistência de um poder censurador do Eu. Mas, ao mesmo tempo, o trabalho do sonho consiste num peculiar tratamento do material de pensamento pré-consciente, em que as partes que o compõem são condensadas, as ênfases psíquicas são deslocadas, o todo é convertido em quadros visuais, dramatizados, e complementado por uma enganadora revisão secundária. Os sonhos também mostram um bom número de traços arcaicos, como o emprego de um simbolismo - predominantemente sexual - que tornamos a encontrar em outras esferas de atividade mental. Além disso, a seu ver, o sonho teria acesso ao material esquecido da infância. (FREUD, Sigmund. "Autobiografia". In: $O$ Eu e o ID, "Autobiografia" e outros textos [1923-1925]. Obras Completas - Vol. XVI. São Paulo: Companhia das Letras, 2014, p.107-108).

${ }^{69}$ FREUD, Sigmund. "Escritores Criativos e Devaneio", op. cit., p.81.
} 
constituição (psíquica) e os impulsos instintuais nela atuantes, ou seja, o que nela era universalmente humano. Nesse sentido, a psicanálise não pode ajudar no esclarecimento do dom artístico, e tampouco lhe toca desvendar os meios e as técnicas com que o artista trabalha ${ }^{70}$. Em resumo sobre as contribuições da psicanálise na compreensão do fazer artístico, Freud declarou que:

O reino da fantasia era um "território protegido", criado na dolorosa transição do princípio do prazer para o da realidade, a fim de tornar possível um sucedâneo para a satisfação instintual que teve de ser abandonada na vida real. Como o neurótico, o artista precisou retirar-se da insatisfatória realidade para esse mundo da fantasia, mas, diferentemente do neurótico, soube encontrar o caminho de volta e novamente fincar os pés na realidade. Suas criações, as obras de arte, eram satisfações fantasiosas de desejos inconscientes, tal como os sonhos, com as quais também tinha em comum a natureza de compromisso, pois também elas precisavam evitar o conflito aberto com as forças da repressão. Mas, à diferença das produções oníricas, associais e narcísicas, eram destinadas a provocar o interesse de outras pessoas, podiam avivar e satisfazer nessas os mesmos desejos inconscientes. Além disso, valiam-se do prazer perceptual na beleza da forma como um "bônus de incentivo",71.

Se utilizarmos o método comparativo, veremos que Vargas Llosa também buscou na infância de García Márquez o estímulo de sua criação ficcional, relacionando as vivências, as lendas, os mitos ouvidos durante sua infância ao processo de criação narrativa, e ainda nos "traumas" ou castrações vividos na juventude como fatores decisivos de uma ruptura com o "mundo real" para então criar mundos verbais. Para Vargas Llosa, há uma intenção central que abarca toda a obra do escritor colombiano, de modo obsessivo e recorrente, uma ambição única que em suas ficções vão se desenvolvendo, com saltos progressivos e às vezes em retrocessos, com a adoção de diferentes perspectivas e métodos distintos. Segundo Vargas Llosa:

Este denominador comum faz com que seus contos e romances possam ser lidos como fragmentos de um vasto, disperso, porém, ao mesmo tempo rigoroso projeto criador, dentro do qual encontra cada um deles sua plena significação. Esta vontade unificadora é a de edificar uma realidade fechada, um mundo autônomo, cujas constantes procedem essencialmente do mundo da infância de García Márquez. Sua infância, sua família, Aracataca constituem o núcleo de experiências mais decisivo para sua vocação: estes 'demônios' têm sido sua fonte primordial, a que outros vieram a enriquecer, a matizar, porém nunca, até agora, a substituir ${ }^{72}$.

\footnotetext{
${ }^{70}$ FREUD, Sigmund. “Autobiografia”, op. cit., p.129.

${ }^{71}$ Ibidem, p. 128.

${ }^{72}$ VARGAS LLOSA, Mario. Gabriel García Márquez: historia de un deicidio. Barcelona: Barral Editores, 1971, p. 91. [tradução nossa].
} 
A intensa relação entre as experiências pessoais e a narrativa ficcional, Vargas Llosa intenta demostrar durante todo o livro, o que García Márquez parece confirmar ao declarar que: "não poderia escrever uma história que não seja baseada exclusivamente em experiências pessoais"73. Para Vargas Llosa, os “demônios” de García Márquez são quase todos procedentes de Aracataca, onde viveu experiências que determinaram sua vocação e seu conflito com a realidade. O primeiro destes foi à separação física de Aracataca, quando foi enviado por seus pais ao internato em Zipaquirá, em Bogotá, onde García Márquez teria descoberto a solidão e começado a "envenenar-se" da realidade, surgindo, então, o desejo de substituí-la. Porém, o acontecimento decisivo se consolida no seu regresso a Aracataca, quando se depara com o envelhecimento da cidade e de sua gente, onde viu sua "memória confrontada pela infidelidade da realidade". Nas palavras de Vargas Llosa: “o maravilhoso mundo que havia levado na memória a Bogotá, no qual havia vivido emocionalmente durante seus anos de internato, através da nostalgia e das recordações, se fez em pedaços: a realidade o destruiu"74.

Para o escritor peruano, os "demônios" que decidem e alimentam a vocação do escritor, podem ser experiências que afetaram especificamente a sua pessoa configurando-se em "demônios pessoais"; ou patrimônio de sua sociedade e de seu tempo, nomeado como "demônios históricos"; ou ainda, experiências indiretas da realidade real, refletidas na mitologia, na arte ou na literatura, sendo estes os "demônios culturais". ${ }^{75}$ A seu ver, toda ficção projeta experiências dessas três ordens, porém, em distintas proporções. No caso de García Márquez, eles coexistem numa espécie de equilíbrio: "sua obra se alimenta em doses parecidas de fatos vividos por ele, de experiências coletivas de seu mundo, e de leituras"76.

De acordo com Vargas Llosa, o "saqueio da realidade real" - nomes, virtudes, vícios, frase, psicologias e objetos - pode ser documentado, ainda melhor, no que diz respeito aos personagens de García Márquez: “os modelos são

\footnotetext{
${ }^{73}$ GARCÍA MÁRQUEZ, Gabriel apud VARGAS LLOSA, Mario. Ibidem, p. 9-10.

${ }^{74}$ VARGAS LLOSA, Mario. Gabriel García Márquez: historia de un deicidio, p.93-94.

75 Vargas Llosa trabalha com as seguintes influências de García Márquez: William Faulkner, Virginia Woolf, Ernest Hemingway, Franz Kafka, James Joyce, Sófocles, François Rabelais, Jorge Luis Borges; os romances de cavalaria; As mil e uma Noites; Um diário do ano da Peste (1722), de Daniel Defoe; e A Peste (1947), de Albert Camus.

${ }^{76}$ VARGAS LLOSA, Mario. Gabriel García Márquez: historia de un deicidio, p.109.
} 
ocasionais ou arquétipos permanentes que inspiram verdadeiras estirpes" ${ }^{, 77}$. Sobre a composição dos personagens do escritor colombiano, diz Vargas Llosa:

[...] a criança imobilizada diante do cadáver de La Hojarasca reproduz uma situação vivida por García Márquez em sua infância; Amaranta Úrsula tecendo sua mortalha recorda a uma tia que fez o mesmo em Aracataca [...]. A descrição de Isabel de La Hojarasca corresponde à imagem de Luisa Santiaga, que García Márquez viu pela primeira vez quando tinha quatro ou cinco anos; Mercedes aparece em Cien años de soledad com seu trabalho de Barranquilla, 'boticária', e no mesmo romance Amaranta Úrsula sonha em ter dois filhos que se chamem Rodrigo e Gonzalo, como os filhos dos García Márquez; os nomes dos jovens conspiradores de El coronel no tiene quien le escriba, e dos amigos de Aureliano Buendía, nos anos finais de Macondo, são os de três companheiros de Barranquilla: Álvaro (Cepeda), Alfonso (Fuenmayor) e Germán (Vargas); o apelido de "La Elefanta", a devoradora de comida, é o do Padre Sagastume, um sacerdote basco que foi professor de García Márquez; a larguíssima velhice de Úrsula Iguarán, cega e meio louca, exagera a de Dona Tranquilina $[\ldots]^{78}$.

O escritor peruano localiza os fatos históricos que afetaram a vida e a vocação de García Márquez, na medida em que as pessoas mais importantes de sua infância foram protagonistas, testemunhas ou vitimas deles. Os avôs maternos, com os quais García Márquez passou os primeiros oito anos de vida, foram, com frequência, suas influências mais sólidas. Quando os avôs de García Márquez, o coronel Nicolás Márquez e sua esposa Dona Tranquilina, chegaram ao povoado de Aracataca, ao finalizar a sangrenta guerra dos mil dias (1899-1902), que devastou o país e o deixou a bancarrota, Aracataca era um minúsculo povoado, situado na província de Magdalena, entre o mar e a montanha. Da narrativa de sua avó, García Márquez escutou as lendas, as fábulas, "as prestigiosas mentiras com que a fantasia popular evocava o antigo esplendor da região, na época auge do cultivo da banana"79. Porém, ainda mais decisivo foi para García Márquez seu avô. Dom Nicolás Márquez era um sobrevivente de pelo menos duas guerras civis, sendo o protótipo de uma estirpe dos coronéis nas obras do escritor colombiano, sobretudo, nas dos Buendía em Cien años de soledad ${ }^{80}$. Esses são alguns exemplos com os quais Vargas Llosa trabalha ao longo das 233 páginas que constituem o primeiro capítulo intitulado "La realidade real" composto pelos subcapítulos: "La realidad como anécdota" e "El novelista y sus demônios" - do livro Gabriel García Márquez: historia de un deicidio (1971).

\footnotetext{
${ }^{77}$ Ibidem, p.115.

${ }^{78}$ Ibidem, p 115-116. [tradução nossa].

${ }^{79}$ Ibidem, p. 15.

${ }^{80}$ GARCÍA MÁRQUEZ, Gabriel apud VARGAS LLOSA, Mario. Ibidem, p.19.
} 
São vastos os exemplos onde à realidade se transforma em anedota para a criação literária. De acordo com Vargas Llosa:

O suplantador de Deus, somente triunfa em sua empreitada de reconstrução da realidade, quando as experiências de seu mundo fictício - transposições verbais de "demônios" pessoais, históricos e culturais - adquirem um caráter "histórico" no sentido de universais, de experiências suscetíveis de serem adotadas ou identificadas como suas por todos os homens $[\ldots]^{81}$.

Para o autor, a origem da vocação do romancista não é necessariamente um trauma particular; podendo ser um trauma geral, sentido de modo mais profundo pelo escritor até chegar ao extremo da reação excessiva, ou seja, a negação da realidade, o desejo de substituí-la. O romancista coloca a seu serviço, como materiais de trabalho, não somente, as experiências que viveu, como também, os sucessos que comoveram a comunidade: as guerras, as pestes, as greves, as lutas políticas, as conquistas ou derrotas, os conflitos sociais, culturais ou religiosos, toda essa massa de experiências comuns que constituem o "acervo histórico" dos homens ${ }^{82}$.

A teoria de Vargas Llosa foi recebida de forma negativa por alguns intelectuais. Críticos como Jorge Aguilar Mora e Ángel Rama a consideravam como negação dos avanços teóricos no campo literário, pois tal teoria recolocava a antiga questão do escritor romântico inspirado pelas musas, ou ainda, do escritor neurótico, com suas obsessões, ou psicótico com suas tendências a substituição da realidade, como na análise freudiana. O que estas críticas pontuavam era o desacordo da teoria e do método vargallosiano com aos esforços modernizadores da crítica literária, que se constituía em outros termos, percebendo na linguagem e na criação narrativa a chave de um processo social no qual o escritor fazia parte ${ }^{83}$.

A psicanálise freudiana partiu da premissa do inconsciente para analisar a obra literária, construindo profundas relações entre a vida e a obra do escritor. Mas, sua análise da psique humana foi sucedida por inúmeras contestações, uma das principais querelas ocorreu entre Freud e Jung. Enquanto, Freud definiu o inconsciente como uma coleção de materiais pessoais reprimidos, Jung dividiu a psique em três partes: a consciência (ego), o inconsciente pessoal e o inconsciente

${ }^{81}$ VARGAS LlOSA, Mario. Gabriel García Márquez: historia de un deicidio, p.119-120. [tradução nossa].

${ }^{82}$ Ibidem, p. 120.

${ }^{83}$ RAMA, Ángel. [1972]. "Segunda respuesta a Mario Vargas Llosa" In: García Márquez y la problemática de la novela. Buenos Aires: Corregidor - Marcha, ediciones, 1973, p. 66-67. 
coletivo, este último uma das razões da discórdia entre os dois. Freud considerava a libido sexual a chave explicativa do comportamento; Jung postulava que a libido sexual era uma força poderosa na psique humana, mas não a única, pois outros fatores irão adquirir importância no desenvolvimento da vida social como, por exemplo, a religião. Ángel Rama, em sua crítica dirigida à teoria dos "demônios" de Vargas Llosa, irá citar exatamente a relação entre a psicanálise de Freud com a teoria do escritor peruano, compreendendo que Vargas Llosa repõe um problema superado por Jung nas divergências de 1912, que teria ultrapassado os pressupostos biológicos e psicológicos de Freud ${ }^{84}$.

Com efeito, a análise de Vargas Llosa na teoria dos "demônios" encontra relação com a perspectiva freudiana sobre o fazer artístico. Porém, o escritor peruano não se baseia de forma integral nestes conceitos, ampliando-os de modo a formular um pensamento próprio. Vargas Llosa empregou diversos métodos em sua análise, como o biográfico, o sociológico e o formal, permitindo que o ensaio Gabriel García Márquez: historia de un deicidio (1971), possa ser lido por diferentes ângulos. Como veremos a seguir, o exame da técnica e das estratégias narrativas de García Márquez adquire grande importância no estudo, relacionando-se a uma segunda fase da produção narrativa. Entretanto, pode-se dizer que não são abandonadas as formas obsessivas que permeiam a análise de Vargas Llosa.

\section{3.}

\section{Em busca do Romance Total}

Uma das grandes obsessões de Vargas Llosa está relacionada às estratégias narrativas, que conferem à ficção o que chama de poder de persuasão sobre o leitor, ou seja, um tipo de ficção total, completa e fechada em si mesma, no termo vargallosiano o romance total. Seus ensaios críticos estão repletos de análises das técnicas e procedimentos dos romancistas no qual se propõe a examinar. Assim, debruçou-se sobre os romances de escritores como Martorell, García Márquez, Flaubert e Victor Hugo, revelando, principalmente, os aspectos que admira na literatura e uma autocrítica, pois, é por meio dos recursos técnicos e

\footnotetext{
${ }^{84}$ Rama, Ángel. [1972]. "El fin de los demônios". In: RAMA, Ángel; VARGAS LLOSA, Mario. García Márquez y la problemática de la novela, op. cit., 1973, p.34.
} 
procedimentos literários, mencionados em suas investigações, que busca aproximar-se do romance total ${ }^{85}$.

O primeiro estudo sistemático de Vargas Llosa sobre o romance total foi publicado em 1969, no ensaio intitulado "Carta de batalla por Tirant lo Blanc", como prólogo a Tirant lo Blanc do catalão Joanot Martorell, publicado pela editora Alianza. ${ }^{86}$ Segundo Vargas Llosa:

Martorell é o primeiro desta estirpe de suplantadores de Deus - Fielding, Balzac, Dickens, Flaubert, Tolstói, Joyce, Faulkner - que pretendem criar em seus romances uma "realidade total", o mais remoto caso de romancista todo-poderoso, desinteressado, omnisciente e ubíquo ${ }^{87}$.

Neste ensaio, o escritor peruano realizou um tributo ao romance de cavalaria, atribuindo a Martorell o melhor proveito do gênero, adaptando-o ao seu tempo e transcendendo-o com a utilização de técnicas que, posteriormente, seriam frequentemente utilizadas no romance moderno. Dentre as várias características do gênero, o autor destacou a ambição da vontade deicida de recriar tudo, "desde o mais infinitamente pequeno até o mais infinitamente grande".

Para Vargas Llosa Tirant lo Blanc (1490) é um romance total, pois é ao mesmo tempo um romance de cavalaria fantástico, histórico, militar, social, erótico e psicológico, não se fixando exclusivamente em nenhuma destas categorias. A obra admitiria diferentes e antagônicas leituras, uma vez que sua natureza varia segundo o ponto de vista que se eleja para ordenar seu caos. Segundo o escritor peruano, Tirant lo Blanc é um dos "modelos" de romance que sonhava alcançar em suas ficções, pois, a noção da realidade dos autores dos romances de cavalaria "abraça num único olhar várias ordens do humano e nesse sentido seu conceito de realismo literário é mais amplo, mais completo que nos

\footnotetext{
${ }^{85}$ Para Carlos Fuentes, o romance de Vargas Llosa La Casa Verde (1965) é um exemplo do que seria um romance total. (FUENTES, Carlos. "El afán totalizante de Vargas Llosa". In: La nueva novela hispanoamericana. México: Joaquín Mortiz, 1969, p.35-48.) Para o crítico dominicano José Alcántara Almánzar, La guerra del fin del mundo (1981), de Vargas Llosa, poderia ser compreendido como um romance total. (ALCÁNTARA ALMÁZAR, José. Narrativa y sociedade en Hispanoamérica. Santo Domingo: Intec, 1984).

${ }^{86}$ Este ensaio foi incorporado ao livro Carta de batalla por Tirant lo Blanc, publicado em 1991, pela Seix Barral, em razão do quinto centenário do livro Tirant lo Blanc (1490) de Joanot Martorell. Os três ensaios que compõem o livro, foram escritos ao longo de trinta anos por Vargas Llosa.

${ }^{87}$ VARGAS LLOSA, Mario. [1991]. Cartas de Batalla por Tirant lo Blanc. Madrid: Santillana Ediciones Generales/Punto de lectura, 2011, p.18. [tradução nossa].
} 
autores posteriores". ${ }^{88}$ Nesse sentido, o autor declara que todas as definições que convém a Tirant lo Blanc não são suficientes, em razão de o romance concentrar personagens facilmente identificados na história, como monarcas e nobres, mas ao mesmo tempo reunir lugares, ações e personagens imaginários. Para o escritor peruano, por um lado, há no romance de Martorell informações minuciosas sobre as guerras, sobre a violência medieval, sobre os costumes da época - dispostos como um vasto material sociológico - por outro, incide sobre ele a dúvida de onde termina a observação, onde começa a invenção. ${ }^{89}$

Após perpetrar uma sequência de questões, que responde de maneira a evidenciar a afirmação acerca da dificuldade de classificação de Tirant lo Blanc, Vargas Llosa chega à conclusão de que se trata de um romance total. Pois, Martorell utilizou todos os materiais que oferecia seu tempo: "a vasta realidade foi seu canteiro ao mesmo tempo seu paradigma, aproveitou fatos históricos, experiências pessoais e, desde logo, [...] saqueou vidas e mortes passadas e contemporâneas". ${ }^{90}$ No romance total, para o escritor peruano, emergem diferentes níveis da realidade: objetivo, que narra às ações e os sucessos exteriores; subjetivo, que revela a vida afetiva dos personagens; retórico ou convencional, que expressa o abstrato; filosófico ou ideológico, próprio de uma sociedade dada; e finalmente, simbólico ou mítico, que relata a parte inconsciente de um indivíduo ou de uma coletividade. Um romance total abarca, portanto, uma realidade plural, atribuindo a todos os seus componentes o mesmo valor ontológico.

Outro aspecto destacado por Vargas Llosa, como um dos critérios de configuração do romance total, é a invisibilidade do escritor, sua imparcialidade diante da criação. Flaubert - uma das suas grandes influências ("demônio" cultural) em termos de técnica narrativa - é, também, citado neste ensaio como o mestre da racionalização sobre a necessidade de abolir o autor, para que a ficção pareça depender somente de si mesma e comunique ao leitor a perfeita ilusão de vida no romance. Mas, segundo o escritor peruano, foi Martorell que quatro séculos antes intuiu que a autonomia de sua ficção era a condição de sua existência, para que seu mundo ganhasse vida, ele deveria banir-se, ou pelo menos

\footnotetext{
${ }^{88}$ Ibidem, p.33.

${ }^{89}$ Ibidem, p.17-38.

${ }^{90}$ Ibidem, p.33.
} 
esconder-se. A realidade criada por ele deveria parecer desinteressada. De acordo com Vargas Llosa:

[...] Suas opiniões pessoais estão habilmente incorporadas a anedotas que é difícil detectá-las. Evidentemente, às vezes, um sentimento de classe é mais forte nele que a 'consciência profissional', como quando rompe sua estratégia reservada de autor para manifestar seu ódio aos juristas, solidariamente com o Duc de Lencastre, e está claro, também, que participa do ressentimento de seus compatriotas contras os genoveses [...]. Porém, essas intromissões do autor são escassas, e a maioria se concentra na última parte do livro $[\ldots]^{91}$.

Em sua conclusão, Vargas Llosa sustentou que os dados históricos de Tirant lo Blanc podem até estar equivocados, mas o romance delata a mentalidade de uma época, "as crenças que estimulavam os homens medievais, os tabus que os paralisavam, o alcance de seus conhecimentos e as fronteiras de seus sonhos". ${ }^{92}$

Existe no pensamento do crítico Vargas Llosa, um tipo de argumentação sobre o romance total que atravessa diferentes ensaios, dentre os quais podemos citar: Gabriel García Márquez: historia de un deicídio (1971); La orgía perpetua: Flaubert y Madame Bovary (1975); Cartas a un joven novelista (1997); La tentación de lo imposible: Víctor Hugo y “Los Miserables” (2004). É importante salientar, que isto não significa que os ensaios de Vargas Llosa sejam uma transposição de tese, pois, cada um dos romances carrega em si suas especificidades de criação, de enredo e autor. Dito isto, podemos considerar que as análises de Vargas Llosa movem-se pela investigação de como estes romances conseguem transmitir uma vibração de vida, um tipo de movimento que suspende a suspeita do leitor, concedendo aos romances um poder de persuasão, uma aparência de vida autônoma. Esta questão, Vargas Llosa parece responder diante da composição das estratégias narrativas, e de uma relação dialética entre ficção e realidade. Nesse sentido, a busca por um romance total está presente nas ficções de Vargas Llosa, através dos procedimentos narrativos que adota; e em sua análise crítica, através de uma argumentação técnica.

No ensaio Gabriel García Márquez: historia de un deicidio, Vargas Llosa distinguiu duas dimensões em Cien años de soledad (1967), que abarcam a amplitude do mundo fictício: a primeira corresponde à expressão da realidade

\footnotetext{
${ }^{91}$ Ibidem, p.38.

${ }^{92}$ Ibidem, p.35.
} 
mais polivalente possível, e a segunda, se desloca no tempo, na história do universo apresentado ${ }^{93}$. De acordo com Vargas Llosa, Cien años de soledad:

[...] é um romance "total", na linha dessas criações insanamente ambiciosas que competem com a realidade real de igual para igual, enfrentando-a com uma imagem de vitalidade, vastidão e complexidade qualitativamente equivalentes. Essa totalidade se manifesta, principalmente, na natureza plural do romance, que é simultaneamente, coisas que se acreditavam antinômicas: tradicional e moderno, local e universal, imaginário e realista. Outra expressão dessa "totalidade" é sua acessibilidade ilimitada, sua faculdade de estar ao alcance [...]. Cien años de soledad é um dos raros casos de obra literária maior contemporânea que todos podem entender e gozar ${ }^{94}$.

Nos critérios de Vargas Llosa, Cien años de soledad concretiza o romance total, uma utopia que combina e concentra as três principais experiências literárias - a biográfica, a histórica e a social - nas quais um escritor pode estar exposto, nomeando-as como "demônios". Cien años de soledad, a seu ver, é um romance total, sobretudo, porque põe em prática o utópico desígnio de todo suplantador de Deus: "descrever uma realidade total, enfrentar a realidade real, uma imagem que é sua expressão e negação"95. E acrescenta:

Esta noção de totalidade, tão escorregadia e complexa, porém, tão inseparável da vocação do romancista, não somente define a grandeza de Cien años de soledad: da também sua chave. Trata-se de um romance total por sua matéria, na medida em que descreve um mundo fechado, desde seu nascimento até sua morte, e em todas as ordens que o compõem - o individual e o coletivo, o lendário e o histórico, o cotidiano e o mítico -, e por sua forma, já que a escritura e a estrutura têm, como a matéria que coagula nelas, uma natureza exclusiva, irrepetível e autossuficiente ${ }^{96}$.

A relação de completude, segundo o escritor peruano, se desenvolve na medida em que todos os planos ou níveis da vida real transcorrem na ficção. A ideia de totalidade em Cien años de soledad torna-se, para Vargas Llosa, ainda mais evidente quando se observa os temas e ações das ficções anteriores de García Márquez. Dessa forma, ele considera, que a edificação da realidade fictícia do escritor colombiano ocorreu de maneira rigorosamente gradual, de romance em

\footnotetext{
${ }^{93}$ VARGAS LLOSA, Mario. Gabriel García Márquez: historia de un deicidio. Barcelona: Barral Editores, 1971, p.545-564.

${ }^{94}$ Ibidem, p.539-540. [tradução nossa].

95 Ibidem, p. 540.

${ }^{96}$ Ibidem, p.540. [tradução nossa].
} 
romance, de conto em conto, tornando a narrativa de Cien años de soledad a completude de um processo iniciado anteriormente ${ }^{97}$.

Vargas Llosa, ao realiza um estudo comparativo, observa que em quase todas as ficções de García Márquez se descrevem "pestes" ou "calamidade", que se abatem intempestivamente sobre a coletividade: em Isabel viendo llover en Macondo (1955), uma chuva de quatro dias chega ao ponto de desaparecer a cidade; em Un día después del sábado (1955), a chuva será de pássaros mortos; em Cien años de soledad (1967), a peste será de insônia e esquecimento, e o dilúvio de quatro anos, aparecendo por último, o vento infernal que leva Macondo pelos ares ${ }^{98}$. Sobre os personagens, Vargas Llosa diz que Cien años de soledad retoma distintas figuras de La hojarasca (1955):

[...] o médico francês o vemos chegar a Macondo, se recorda que comia erva como os burros e que se suicidou enforcando-se numa viga. Ademais, completa a história desse romance, despejando o dado escondido final, ao afirmar que o médico "havia sido enterrado contra a vontade do povo por um antigo companheiro de armas do coronel Aureliano Buendía”. La hojarasca terminava quando o coronel iria enterrar o suicida e deixava uma pergunta: cumpriria sua promessa, o povo encolerizado o permitiria? Agora sabemos que a cumpriu, que a vontade do coronel foi mais forte que a dos macondinos. Outros personagens que regressam: o Cachorro, de quem sabíamos que havia lutado nas guerras, porém, somente aqui se precisa em qual (na "primeira guerra federalista") [...]; a viúva Rebeca, um rosto efêmero em $L a$ hojarasca, aparece aqui com toda sua fértil biografia, e o único índio com nome próprio de Cien años de soledad se chama como o único índio com nome próprio de La hojarasca, Cataure [... $]^{99}$.

Além do método comparativo das ficções, Vargas Llosa dedica um longo capítulo ao tratamento da "matéria real objetiva", que diz respeito aos dados da vida de García Márquez, considerando que o caráter totalizador de Cien años de soledad, decorre da relação desta com a "matéria real imaginária". A categoria do imaginário é dividida por Vargas Llosa em quatro planos: “o mágico, o míticolendário, o milagroso e o fantástico":

Chamo "mágico", ao fato real imaginário provocado mediante artes secretas por um homem ("mago") dotado de poderes ou conhecimentos extraordinários; "milagroso", ao fato imaginário vinculado a um credo religioso e supostamente decidido ou autorizado por uma divindade, ou que faz supor a existência de uma vida após a morte; "mítico-lendário", ao fato imaginário que procede de uma realidade "histórica" sublimada e pervertida pela literatura, e "fantástico", ao fato

\footnotetext{
${ }^{97}$ Ibidem, p.78.

${ }^{98}$ Vargas Llosa relacionou, neste processo de continuidade, os lugares das ficções de García Márquez: Macondo, "el Pueblo" e a localidade marina. Ibidem, p.213-214.

${ }^{99}$ Ibidem, p.543. [tradução nossa].
} 
imaginário "puro", que nasce da estrita invenção e que não é produto nem da arte, nem da divindade, nem da tradição literária: o fato real imaginário que ostenta como sua característica uma soberana gratuidade ${ }^{100}$.

A ilusão de soberania do romance é analisada, por Vargas Llosa, segundo a forma que concretiza a narrativa. São técnicas, métodos de escrita e estratégias de composição, que o escritor peruano examina com o intuito de observar os usos e efeitos que produzem em relação ao poder de persuasão e a perspectiva de um mundo total dentro do romance. Nesse sentido, o autor desenvolveu toda uma nomenclatura para analisar as estratégias narrativas: "muda", "salto qualitativo", "elemento acrescentado", "vasos comunicantes", "caixa chinesa", e "dado escondido". Deve-se observar que em muitos casos os termos que Vargas Llosa utiliza para elaborar seus conceitos não são criações próprias, tampouco são as técnicas que descreve. Estas últimas são recursos, que segundo o próprio autor, surgiram com o começo do romance e que são utilizados em larga escala, de uma forma ou de outra, pelos romancistas. Ao invés de manter os nomes pelos quais se conhecem estes estratagemas, o escritor peruano os batiza com nomes que evocam imagens comuns.

O recurso denominado "muda" pelo escritor peruano, consiste em uma alteração em qualquer um dos pontos de vista da narrativa, podendo ser espacial, temporal ou de nível da realidade ${ }^{101}$. Sempre que se altera a perspectiva espacial do relato, porque o narrador muda de lugar (por meio do deslocamento da pessoa verbal de um "ele" para um "eu", de um "eu" para um "ele", ou outras), uma "muda" espacial ocorre ${ }^{102}$. No caso de Cien años de soledad, é a mudança da primeira para a última frase do romance, que Vargas Llosa toma como exemplo deste procedimento. $\mathrm{O}$ narrador que antes estava fora da realidade fictícia, passa a formar parte dela, convertendo-se no narrador personagem, omnisciente, porém implicado. Com Aureliano, que decifra os pergaminhos, que outros personagens

\footnotetext{
${ }^{100}$ Ibidem, 597. [tradução nossa].

${ }^{101}$ Optamos por utilizar a nomenclatura "muda" assim como no espanhol, pois, nas traduções para o português este recurso aparece como "muda" ou "guinada”, ver: VARGAS LLOSA, Mario. [1997]. Cartas a um jovem escritor. Elsevier, 2006, p.124.

${ }^{102}$ Segundo Vargas Llosa, em certos romances, essas "mudas" são frequentes e em outros são raras. Apenas o resultado final indicará se foram úteis ou prejudiciais e que efeito produziram sobre o poder de persuasão da história, reformando-o ou reduzindo-o. Para ele, "quando são eficazes, as "mudas" espaciais conseguem passar uma visão ampla, diversificada e mesmo global e abrangente da historia (e com isso produzir a ilusão de independência do mundo real, o que, [...] é a aspiração secreta de qualquer mundo ficcional). Se não forem eficazes, as "mudas" podem gerar confusão: o leitor fica desorientado pelos repentinos e arbitrários saltos na perspectiva a partir da qual a historia é contada". Ibidem, p.122.
} 
já haviam tentado ler sem êxito, o leitor descobre que ali está à história de Macondo e da família Buendía, "escrita por Melquíades até em seus detalhes mais triviais com cem anos de antecipação" ${ }^{" 103}$. A leitura do manuscrito aproxima o tempo da narrativa, os cem anos passados coincidem com o tempo presente. $\mathrm{O}$ narrador até então na perspectiva de um "narrador-Deus", revela-se como um "narrador-personagem" (dotado de poderes mágicos, um personagem real imaginário), que narra a história indiretamente, através de alguns manuscritos, escritos dentro do romance. Somente nas últimas linhas, o leitor descobre que Melquíades é o narrador de Cien años de soledad ${ }^{104}$. No decorrer da trama, ocorrem também as "mudas secundarias" quando os personagens se sucedem como narradores.

De acordo com Vargas Llosa, o estratagema do deciframento dos manuscritos é uma canibalização de seu próprio narrador, pois no instante que o narrador e o narrado coincidem ambos desaparecem, criando a ilusão de que nada existe fora da própria realidade. Segundo o autor, a realidade fictícia é tudo:

nela mesma se acha sua origem, é, simultaneamente, quem cria e o criado, o narrador e o narrado, e assim como sua vida é toda a vida, sua morte é também a extinção de tudo: o romance perpetra assim o mesmo deicídio que o romancista quer perpetrar no exercício de sua vocação, esta ambição se reflete naquela. Porém, em ambos os casos, essa pretensão somente consegue uma aparência, uma miragem ${ }^{105}$.

Ao revelar ao leitor que o narrador e o narrado não são realidades diferentes, se produz também uma mudança no ponto de vista temporal. As "mudas temporais" ocorrem quando há um deslocamento do narrador no tempo, desenvolvendo a narrativa simultaneamente no passado, no presente e no futuro. Para o escritor peruano, quando a técnica é bem utilizada, empresta a historia uma ilusão de completude cronológica e de autossuficiência temporal ${ }^{106}$. Por exemplo, quando Aureliano começa a "decifrar o instante que estava vivendo, decifrando-o à medida que o vivia, profetizando a si mesmo no ato de decifrar a última página dos pergaminhos, como se estivesse vendo um espelho que fala". ${ }^{107}$ Nesse instante, os dois planos temporais futuro onde fala o narrador e o passado onde

\footnotetext{
${ }^{103}$ VARGAS LLOSA, Mario. Gabriel García Márquez: historia de un deicidio, p.610.

${ }^{104}$ Ibidem, p.610-611.

${ }^{105}$ Ibidem, p.612. [tradução nossa].

${ }^{106}$ VARGAS LLOSA, Mario. [1997] Cartas a um jovem escritor, p.122-123.

${ }^{107}$ VARGAS LLOSA, Mario. Gabriel García Márquez: historia de un deicidio, p.618.
} 
fala o narrado, em teoria e não na prática, se fundem em um só plano. Segundo Vargas Llosa, "não somente desaparece o tempo de Macondo: ao desaparecer o tempo do narrador, desaparece todo o tempo. O narrado era todo o tempo". ${ }^{108}$ Ademais, ao produzir a fusão temporal, se produz uma curva cronológica, que pode ser chamada de linear: "a história começa pelo princípio (fundação de Macondo) e acaba no final (sua desaparição)" ${ }^{\text {"109 }}$. A relação entre o tempo, desde o que se narra e o tempo narrado, determina, também, o tempo verbal que usa o narrador e suas possibilidades.

O ponto de vista temporal decide a organização do tempo na realidade fictícia. Para Vargas Llosa, este é o principal “elemento acrescentado”, uma vez que a estrutura temporal da realidade fictícia não coincide jamais com o da realidade real. A impressão inicial em Cien años de soledad, é que o narrador está situado num futuro e o narrado em um passado. Essa colocação temporal permite ao narrador dominar, permanentemente, toda a trajetória cronológica da realidade fictícia e associar os fatos que narra com fatos do passado remoto. $\mathrm{Na}$ análise de Vargas Llosa, o tempo do narrado é um tempo fechado sobre si mesmo, com um princípio e um fim, onde o narrador pode nomear o sucedido em qualquer instância (passado, presente e futuro); "o tempo de Macondo é um círculo, uma totalidade, uma estrutura autossuficiente" ${ }^{, 110}$.

Este contraponto, entre o plano do narrador e do narrado, não se mantém do princípio ao fim no romance, conforme pontua o escritor peruano, se isso ocorresse à realidade fictícia, provavelmente, daria uma impressão de total artifício. De modo que o ponto de vista do nível de realidade é variável:

[...] há momentos em que os termos da realidade fictícia são semelhantes aos da realidade real: a relação das guerras civis, por exemplo, ou a greve e a matança dos trabalhadores, episódios que em seu conjunto formam uma matéria real objetiva, estão narrados, também, a partir de uma perspectiva (mais ou menos) real objetiva $^{111}$.

As "mudas" no nível de realidade ocorrem quando a história, que até então transcorria em um plano "realista", histórico e objetivo, passa para a realidade fantástica, um plano puramente imaginário, um território habitado por seres despidos de existência física - ou vice-versa. Neste caso, trata-se, também, do que

\footnotetext{
${ }^{108}$ Ibidem, p. 619. [grifos do autor].

${ }^{109}$ Idem.

${ }^{110}$ Ibidem, p.617.

${ }^{111}$ Ibidem, p.645. [tradução nossa].
} 
Vargas Llosa nomeia como “salto qualitativo”, pois há uma alteração na essência da narrativa, de um mundo realista para outro, puramente fantástico ${ }^{112}$. Assim, "o narrador salta ao imaginário para narrar o real objetivo e ao real objetivo para narrar o imaginário"113. Esta mudança no nível de realidade determina, junto com o ponto de vista temporal, o "elemento acrescentado" da realidade fictícia.

O "exagero" é uma das estratégias que permitem criar um mundo fantástico sem colocar diante do leitor seres intrinsecamente imaginários, como um unicórnio ou um centauro, e que por ocorrer de maneira frequente adquirem um caráter de normalidade no romance. Segundo Vargas Llosa, aumentar as propriedades dos seres, dos objetos e as situações é um procedimento de escritura tanto como de estrutura ${ }^{114}$. Nesse sentido está à narrativa, no primeiro capítulo de Cien años de soledad, em que os ciganos levam a Macondo os novos "inventos"; o primeiro é o "imã", no qual identificamos no ato como real objetivo, dotado de propriedade e limites que conhecemos. Porém, na realidade fictícia estas propriedades são aumentadas, estes limites alargados de maneira brutal. As operações que realiza este imã maximizam em termos quantitativos as que realizam os imãs na realidade real:

Um cigano corpulento, de barba rude e mãos de pardal, que se apresentou com o nome de Melquíades, fez uma truculenta demonstração pública daquilo que ele mesmo chamava de a oitava maravilha dos sábios alquimistas da Macedônia. Foi de casa em casa arrastando dois lingotes metálicos, e todo mundo se espantou ao ver que os caldeirões, os tachos, as tenazes e os fogareiros caíam do lugar, e as madeiras estalavam com o desespero dos pregos e dos parafusos tentando se desencravar, e até os objetos perdidos há muito tempo apareciam onde mais tinham sido procurados, e se arrastavam em debandada turbulenta atrás dos ferros mágicos de Melquíades ${ }^{115}$.

Outro dos 'inventos' é uma dentadura postiça, algo tão real objetivo como o imã, contudo, salta ao imaginário, pois é capaz de rejuvenescer Melquíades, provocando um assombro descomunal. Poderíamos seguir enumerando outras situações nas quais são exageradas a natureza dos objetos ou as características dos

\footnotetext{
${ }^{112}$ Vargas Llosa em Cartas a un joven novelista declarou que o termo "saltos qualitativos" tratase de um empréstimo da dialética hegeliana, segundo a qual, "o acúmulo quantitativo detona 'um salto de qualidade' (como ocorre, por exemplo, com a água, que ao ferver indefinidamente se transforma em vapor, ou ao esfriar em demasia vira gelo)". Ver, VARGAS LLOSA, Mario. [1997]. Cartas a um jovem escritor, op. cit., p.125.

${ }^{113}$ VARGAS LLOSA, Mario. Gabriel García Márquez: historia de un deicidio, op. cit., p.643.

${ }^{114}$ Ibidem, p.655.

115 GARCÍA MÁRQUEZ, Gabriel. [1967]. Cem anos de solidão. 48 ${ }^{\mathrm{a}}$ ed. Rio de Janeiro: Editora Record.[s. d.], p.5.
} 
seres, mas, nos importa perceber que nestes exemplos ocorre uma desmesura da experiência real, o que Vargas Llosa considera como outro componente do "elemento acrescentado". De acordo com o escritor peruano, para edificar a realidade fictícia, de Cien años de soledad:

o autor usou, entre os materiais da realidade real, um número superior ao de todas as ficções anteriores juntas, os de maior predisposição imaginária: objetos insólitos, seres pitorescos e extravagantes, ciganos, aventureiros, inventores, nômades, praticantes de ofícios estranhos ou anacrônicos ${ }^{116}$.

O exagero tende a organizar-se como um elemento "exótico", que se descola do real objetivo e ingressa no imaginário. Como observa Vargas Llosa, este é por definição o distinto e o distante, o desconhecido, o outro, carregado de mistério e de imprevisibilidade ${ }^{117}$. Nesse sentido, os ciganos são o maior exemplo da carga "irrealizante” do caráter exótico:

[...] de origem desconhecida, andam pelo mundo, praticam a prestidigitação e a magia, se lhes atribuem poderes ocultos, seu mundo estimula a fantasia e a invenção. Se fosse feito um registro de seres, objetos e lugares de Cien años de soledad se encontraria, talvez, que a maioria deles tem uma personalidade exótica, que os inclina ao imaginário ${ }^{118}$.

Além do exagero, Vargas Llosa percebe como procedimentos da estratégia narrativa a enumeração, a repetição, e as qualidades que adjetivam os objetos. Estes procedimentos são, também, "as leis" que governam a realidade fictícia. O autor acrescenta, ainda, a relação contrapontística que impõe sua marca à realidade fictícia, onde o real objetivo e o imaginário aparecem como entidades autônomas, interligando-se ao procedimento nomeado como "vasos comunicantes". Estes ocorrem quando dois ou mais episódios que tenham lugar em tempos diversos, locais diversos ou níveis diversos de realidade são entremeados, por decisão do narrador a fim de que tal vizinhança contamine-se reciprocamente. O fator decisivo é a "comunicação" entre os episódios, ou seja, a mera justaposição não basta, para que o processo funcione. Segundo Vargas, "a unidade que essa técnica narrativa cria faz com que o episódio assim construído seja sempre algo mais que mera soma de suas partes" ${ }^{119}$. A seu ver, em Cien años

\footnotetext{
116 VARGAS LLOSA, Mario. Gabriel García Márquez: historia de un deicidio, op. cit., p.653. [tradução nossa].

${ }^{117}$ Ibidem, p.653.

${ }^{118}$ Ibidem, p.653-654. [tradução nossa].

${ }^{119}$ VARGAS LLOSA, Mario. [1997]. Cartas a um jovem escritor. Op., cit., p.169.
} 
de soledad há uma mescla narrativa entre os episódios de levitação do padre Nicanor Reyna, narrado com a mesma objetividade do desaparecimento do armênio taciturno ou a ressurreição de Melquíades ${ }^{120}$.

Outro procedimento que Vargas Llosa analisa é a "caixa chinesa" ou "boneca russa". Este consiste em contar uma história que gera outras histórias derivadas, realidades primárias e secundárias, colaborando com a percepção do mistério, da ambiguidade, da complexidade sobre o conteúdo narrativo, produzindo o efeito de multiplicação da narrativa ${ }^{121}$. O mesmo procedimento foi denominado por Tzvetan Todorov como "narrativas de encaixe" ${ }^{122}$. Segundo Vargas Llosa, esse procedimento favorece a dissimulação da presença do escritor como enunciador na obra, pois a introdução dos fatos é realizada pelos próprios personagens, construindo uma multiplicidade de vozes narrativas. Assim, no instante em que se realiza a mudança no ponto de vista espacial nas páginas finais de Cien años de soledad, quando o narrador-Deus é revelado como um narradorpersonagem, implicitamente se produz uma "caixa chinesa", um desdobramento do narrador ${ }^{123}$.

Por fim, vejamos o que Vargas Llosa denomina como o "dado escondido". Trata-se dos silêncios significativos, dados escamoteados pelo narrador que providencia para que as informações que omite agucem a imaginação do leitor de modo a obrigá-lo a preencher os "vazios" da história com hipóteses e conjecturas de sua própria lavra. Para Vargas Llosa, o dado escondido não pode ser gratuito e arbitrário. É vital que o silêncio do narrador tenha sentido, que exerça uma influência inequívoca sobre a parte explícita da história, "que essa ausência se faça sentir e desperte a curiosidade, as expectativas e as fantasias do leitor" ${ }^{124}$. A seu ver, Hemingway foi um mestre exímio do uso desta técnica, como fica evidente em Os assassinos $(1927)^{125}$. Por sua vez, ele identifica Hemingway como

\footnotetext{
${ }^{120}$ VARGAS LLOSA, Mario. Gabriel García Márquez: historia de un deicidio, op. cit., p.648.

${ }^{121}$ VARGAS LLOSA, Mario. [1997]. Cartas a um jovem escritor, op. cit., p.137.

122 Segundo Todorov, “[...] o encaixe é uma explicitação da propriedade mais profunda da narrativa. Pois a narrativa encaixante é a narrativa de uma narrativa. Contando a história de uma outra narrativa, a primeira atinge o seu tema essencial e, ao mesmo tempo, se reflete nessa imagem de si mesma; a narrativa encaixada é ao mesmo tempo a imagem dessa narrativa abstrata da qual todas as outras são apenas partes ínfimas, e também da narrativa encaixante, que a precede diretamente. Ser a narrativa de uma narrativa é o destino de toda narrativa que se realiza através do encaixe". (TODOROV, Tzvetan. As estruturas narrativas. São Paulo: Perspectiva, 2006, p.126).

${ }^{123}$ VARGAS LLOSA, Mario. Gabriel García Márquez: historia de un deicidio, p.612-613.

${ }^{124}$ VARGAS LLOSA, Mario [1997]. Cartas a um jovem escritor, p.150.

${ }^{125}$ Ibidem, p. 151.
} 
um dos principais "demônios culturais" de García Márquez, a partir de El coronel no tiene quien le escriba (1961), justamente no que concerne ao emprego da técnica do "dado escondido"126.

Em Cien años de Soledad, um exemplo do emprego do "dado escondido" é a história de Amaranta que tece sua mortalha e morre ao terminá-la. Os dois fatos (mortalha e morte) não estão narrados simultaneamente, sendo deslocados para momentos distintos, abrindo um futuro enigmático, que implica uma interrogação sobre suas motivações, circunstâncias e o processo do qual resultou. A estrutura temporal circular converte, de acordo com Vargas Llosa, o episódio num "dado escondido em hipérbato": "o enigmático feito inicial vai se despejando pouco a pouco de suas incógnitas (suas motivações, suas circunstâncias, a cadeia de eventos que culminaram nele)", tornando-se totalmente claro em sua ultima menção, quando o círculo se encerra ${ }^{127}$. O “dado escondido em hipérbato" ocorre quando o fato é deslocado apenas momentaneamente, revelando-se em algum outro momento, ou seja, o dado deslocado vai se clarificando ao passo em que aparecem os fatos que os precederam. Enquanto o “dado escondido em hipérbato” é abundante no romance de García Márquez, o “dado escondido elíptico”, aquele em que o fato ou feito que gera a ação no romance são abolidos permanentemente, ocorre, segundo o escritor peruano, apenas no episódio da morte de José Arcadio Buendía, quando o narrador declara: "Este foi talvez o único mistério que nunca se esclareceu em Macondo"128.

\footnotetext{
${ }^{126}$ VARGAS LLOSA, Mario. Gabriel García Márquez: historia de un deicidio, op. cit., p.165.

${ }^{127}$ Ibidem, p.632.

${ }^{128}$ GARCÍA MÁRQUEZ, Gabriel. Cem anos de solidão, op. cit., p.76.
} 


\section{4. \\ Vargas Llosa, antagonismos e dissidências}

Em meados da década de sessenta, a dinâmica do cenário político e cultural na América Latina sofreu uma série de alterações. As utopias e esperanças de uma revolução socialista a nível continental começaram a enfraquecer-se diante da crise econômica enfrentada por Cuba e a burocratização do campo cultural. Neste cenário, começam a aparecer às primeiras divergências da comunidade intelectual de esquerda em torno da Revolução Cubana. Embora o projeto das esquerdas chilenas com Salvador Allende (1970-1973) mantivesse acesa a esperança da perspectiva socialista, os movimento e conquistas sociais enfrentavam uma realidade marcada por perseguições, repressão e censura. Cenário cuja angústia da repressão foi levada ao limite pelo recrudescimento das ditaturas civis e militares em solo latino-americano, fechando um ciclo de desenvolvimento institucional do campo cultural na América Latina, instituindo e oficializando políticas conservadoras e violentas.

Nesse panorama se acirram os dilemas da comunidade intelectual de esquerda, levando de modo geral a um antagonismo dos posicionamentos, o que provocou uma série de polêmicas em torno do papel do intelectual, da função político-social da literatura e das perspectivas socialistas na e para a América Latina. Questões que avançaram sobre o modo pelo qual estes intelectuais encaravam o processo de expansão e internacionalização do romance latinoamericano, sobretudo, o que se compreendeu como implicações do boom. Para Germán Albuquerque Fuschini, a ruptura da rede intelectual formada por distintos agentes na década de sessenta, pode ser situada dentro de um processo que teve como fatores a prisão do poeta Heberto Padilla, a proliferação de ditaduras militares na América Latina, o desgaste do fenômeno literário do boom ou até mesmo uma mudança geracional entre os escritores ${ }^{1}$.

\footnotetext{
${ }^{1}$ ALBURQUERQUE FUSCHINI, Germán. "El caso Padilla y las redes de escritores latinoamericanos". Revista Universum, Chile, Universidade de Talca, n. 16, 2001, p. 309. Estes acontecimentos marcam, também, a periodização de alguns críticos e escritores referente ao boom narrativo. Para José Donoso, por exemplo, o boom pode ter se iniciado, em 1962, com o Congreso de Intelectuales de Concepción e a publicação de La ciudad y los perros (1963), de Mario Vargas Llosa, e teria terminado por volta de 1972, por vários motivos, entre eles a prisão do poeta Heberto Padilla e a dispersão dos intelectuais em torno de Cuba. (DONOSO, José. Historia personal del boom. Barcelona: Seix Barral, 1983, p. 36-46). Para Saúl Sosnowski, uma possibilidade de
} 
Mario Vargas Llosa posicionou-se diante dos acontecimentos políticos, sociais e culturais da época, em alguns momentos, chegou a ter uma atuação protagonista nos debates, fator que teve consequências diretas na maneira como foram recebidas suas ideias literárias e reavaliadas suas obras ficcionais. Na época da publicação do ensaio Gabriel García Márquez: historia de un deicidio (1971), o escritor peruano esteve inserido em dois debates que ocorreram numa linha temporal muito próxima. O primeiro ocorreu em 1969, envolvendo Vargas Llosa, Óscar Collazos e Julio Cortázar, cuja discussão girou em torno do conceito de realidade na literatura, centrada no engajamento do escritor e seu comprometimento com as causas político-sociais na América Latina. Em grande medida, o contexto político-ideológico e os posicionamentos dos agentes foi o fator principal do debate, revelando as tensões do campo literário no final dos anos sessenta. O segundo debate está centrado em torno do papel do intelectual na e para a Revolução. Os antagonismos adquirem contornos dramáticos com a prisão do poeta Heberto Padilla e sua autocrítica, em 1971, gerando quadros de dissidência. Neste capítulo, mostraremos os posicionamentos e a formulação do pensamento de Vargas Llosa diante das práticas do governo cubano, com especial atenção aos processos desencadeados durante e pós o "caso Padilla".

\section{1. Rebeldia ou Revolução? Julio Cortázar, Vargas Llosa e Óscar Collazos}

A polêmica sustentada pelo colombiano Óscar Collazos, o argentino Julio Cortázar e o peruano Mario Vargas Llosa, nas páginas do semanário Marcha, pode ser compreendida como uma das primeiras confrontações a respeito da cosmovisão do escritor peruano sobre a vocação do escritor e a natureza da literatura ${ }^{2}$. Categorias centrais na argumentação desenvolvida por Vargas Llosa no livro Gabriel García Márquez: historia de un deicido (1971).

periodização pode ser formulada entre 1959, com o triunfo da Revolução Cubana, até 1973, com a queda da democracia no Chile. (SOSNOWSKI, Saúl. "La 'nueva' novela hispanoamericana: ruptura y 'nueva' tradición”. In: PIZARRO, Ana (org.). América Latina: palavra, literatura e cultura, 1995, vol 3, p.71).

${ }_{2}^{2}$ Todos os textos em torno desse debate estão reunidos no livro Literatura en la revolución y revolución en la literatura, publicado no México em 1970, pela Siglo XXI. 
O debate teve início com a publicação do ensaio de Óscar Collazos, Encrucijada del linguaje ${ }^{3}$. Neste ensaio, o escritor colombiano rechaça a noção de autonomia da literatura frente à realidade. A seu ver, trata-se de uma artificialidade criada pelo aparato editorial do chamado boom, nutrida pela emergência de novos narradores que - "desesperadamente" - buscavam sua inserção em um mercado continental, cuja "atualização" da linguagem narrativa retomava com intensidade a influência da literatura europeia e norte-americana, concebendo a literatura como exercício autônomo do contexto sociocultural e político. Para Collazos, estas concepções induziam a uma suposta consciência histórica e responsabilidade intelectual, traduzida na divisão esquemática entre o ato criador e a ação intelectual ${ }^{4}$.

Collazos recuperou o significado do discurso de Fidel Castro, Palabras a los intelectuales (1961), no qual o primeiro ministro cubano afirmava que num contexto revolucionário, o escritor é também um revolucionário; para justificar que a Revolução Cubana oferecia a possibilidade real de afirmação cultural, um desafio frente às "formas refinadas do neocolonialismo cultural". Neste sentido, afirma Collazos: "somos um continente em revolta porque a revolta é impossível entre os antigos colonizadores, somos um continente com a revolução socialista, porque esta é uma impossibilidade neles". Assim, para ele, a condição do escritor latino-americano promulgava a necessidade de ir além da escrita dos romances, poesias ou contos, era preciso participar dos debates da vida social, denunciando as situações de injustiça ${ }^{5}$. A seu ver, o intelectual deveria romper com o "complexo de inferioridade frente à metrópole", pois somente assim poderia estar de acordo com as novas formas de existência que suscitavam o pensamento emancipador da Revolução Cubana.

$\mathrm{Na}$ perspectiva de Óscar Collazos, obras como Zona sagrada (1967) e Cambio de piel (1967), de Carlos Fuentes, e, 62, modelo para armar (1968), de Julio Cortázar, possuíam uma excessiva estetização do real, seguindo mecanicamente os enunciados do estruturalismo europeu ou "as remotas origens

\footnotetext{
${ }^{3}$ O ensaísta, escritor, jornalista e crítico literário colombiano Óscar Collazos, foi diretor do Centro de Investigaciones Literarias da instituição cultural Casa de las Américas. Entre suas principais publicações estão: Crónica de tiempo muerto (1975), Todo o nada (1979), Fugas (1988), Las trampas del exilio (1992), Adiós a la Virgen (1994), Morir con papá (1997) y La modelo asesinada (1999).

${ }^{4}$ COLLAZOS, Óscar. "La encrucijada del linguaje". In: Literatura en la revolución y revolución en la literatura. México: Siglo XXI, 1970, p.7.

${ }^{5}$ Ibidem, p. 9
} 
do estruturalismo russo", cujo efeito na literatura era, a seu ver, o distanciamento cada vez maior da realidade ${ }^{6}$. Nesse sentido, Collazos criticou a afirmação de Vargas Llosa de que "a literatura não pode ser valorada por comparação com a realidade. Deve ser uma realidade autônoma, que existe por si mesma"”. De acordo com o escritor colombiano, este argumento baseia-se numa mistificação perigosa que poderia motivar muitos escritores jovens a conceber a literatura em termos absolutos de autonomia, a descobrir no fato criador outra realidade, “tirânica e arbitraria remanescente dos 'vanguardismos' do início do século XX, registrados nas discussões dos anais do folclore cultural, ao invés de reflexões críticas" $"$.

Apostando na contradição entre os argumentos de Vargas Llosa e o pacto com a realidade latino-americana expressa em seus romances, Collazos assinala que como escritor, Vargas Llosa possuía um "talento vertiginoso e real", mas como intelectual era um teórico seduzido pelas correntes do pensamento europeu.

Assim, declara o colombiano:

A propósito das afirmações de Vargas Llosa de que "a literatura não pode ser valorada por comparação com a realidade" devemos lembrar (e lembrar o autor) de que maneira um romance como La ciudad y los perros se torna evidentemente decisivo e crucial, uma vez que não seja por comparação do instrumento verbal e os recursos estilísticos que ele mesmo elabora, da correspondência do romance com um mundo específico, da relação entre o objeto (instrumento) com a realidade. Esta correspondência é inevitável e, é o mesmo Vargas Llosa quem através de reportagens, artigos e mesas redondas tem insistido nas anedotas que motivaram sua obra, coisa que o leitor não pode desconhecer, uma vez lida a mesma. Em outras palavras, os mecanismos do leitor conduzem a esta confrontação e é aqui onde a crítica encontra sua funcionalidade e razão de ser: em ser mediadora entre a obra de arte e o receptor da mesma?.

Nessa dimensão, os "demônios" do romancista e a imagem do escritor em disputa com a realidade, formulados por Vargas Llosa, são para Collazos uma proposta intelectual escapista, uma forma de fechar deliberadamente os olhos para o contexto sociocultural e político latino-americano, um modo de não confrontar a

\footnotetext{
${ }^{6}$ Ibidem, p.10.

${ }^{7}$ VARGAS LLOSA, Mario apud COLLAZOS, Óscar, op. cit., p.9.

${ }^{8}$ COLLAZOS, Óscar, op. cit., p.9-10. A crítica de Collazos aos "vanguardismos" nas artes, estava inteiramente de acordo com as percepções do governo cubano que, sobretudo, após o I Congresso Cultural de la Habana (1968), compreendia este tipo de experimentação literária como uma estética pequeno-burguesa de difícil assimilação pelas massas. Sobre a política cultural em Cuba deste período, ver: VILLAÇA, Mariana Martins. O Instituto del Arte e Industria Cinematográficos (ICAIC) e a política cultural em Cuba (1959-1991). 434 f. 2 v. Tese. FFLCH (Departamento de História), USP, São Paulo, 2006.

${ }^{9}$ COLLAZOS, Óscar. "La encrucijada del linguaje", p.18. [tradução nossa].
} 
realidade por meio de sua obra. Embora defina vagamente esta realidade, Collazos situa o livro Cien años de soledad (1967), de García Márquez, como modelo de literatura que desvela todo um aparato social, "desentranha toda uma realidade que, inclusive em seus momentos mais inverossímeis", nos remete "ao contexto

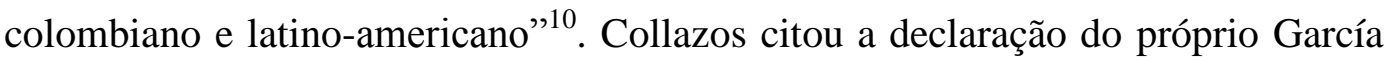
Márquez como prova de seus argumentos, que dizia crer "que particularmente em Cien años de soledad" era um escritor "espontaneamente realista", porque "na América Latina tudo é possível, tudo é real". Desse modo, o escritor deveria "trabalhar em investigações da linguagem e de formas técnicas do relato, a fim de que toda esta fantástica realidade latino-americana fizesse parte de nossos livros"11.

Julio Cortázar foi o primeiro a responder as críticas de Collazos. Sua resposta, foi publicada em dezembro de 1969, com o título Literatura en la revolución y revolución en la literatura: algunos malentendidos a liquidar. Cortázar afirmou que, apesar de se sentir solidário com os processos revolucionários na América Latina, não se sentia na obrigação de entregar sua obra a enunciados e proclamas que pouco contribuía à história e à literatura. Assim, o escritor argentino acrescenta que Collazos:

acredita ver uma atitude de subserviência ou imitação de estruturas narrativas estrangeiras, quando o que sucede na realidade é que já não há nada estrangeiro nas técnicas literárias porque o empequeñecimiento do planeta, as traduções que seguem quase imediatamente as edições originais, o contato entre os escritores, eliminam cada vez mais os compartimentos estanques que outrora cumpriam as diversas literaturas nacionais ${ }^{12}$.

Para Cortázar, as formulações de Collazos eram contraditórias e refletiam ao mesmo tempo um sentimento de inferioridade e de superioridade expressos na frase: "somos incapazes de responder, em atos culturais, na mesma medida em que o continente e alguns de seus homens têm respondido em atos políticos", afirmação que pressupunha uma confusão tácita entre literatura e luta política, uma concepção deformada e deformante da realidade ${ }^{13}$. Além disto, afirmou o

\footnotetext{
${ }^{10}$ Ibidem, p.28.

${ }^{11}$ GARCÍA MÁRQUEZ, Gabriel apud COLLAZOS, Óscar. "La encrucijada del linguaje". In: Literatura en la revolución y revolución en la literatura. México: Siglo XXI, 1970, p. 28-29.

${ }^{12}$ CORTÁZAR, Julio. "Literatura en la revolución y revolución en la literatura, p.40. [tradução nossa, grifos do autor].

${ }^{13}$ Ibidem, p.42-43.
} 
escritor argentino que os argumentos de Collazos baseavam-se no intelectual teórico e não no escritor como criador, desse modo, seu interesse estava centrado numa realidade de tipo imediata. Para Cortázar, a noção de realidade de Collazos, apesar de tomar os cuidados para não cair no vocabulário que levou a noção e as consequências do realismo socialista, compreendia o narrador latino-americano analogamente aos problemas e tensões criados dentro desta corrente estética ${ }^{14}$. De acordo com Cortázar:

De fato, nenhuma realidade é concebível no vazio; o poema mais abstrato, a narração mais delirante ou mais fantástica não alcança transcendência se não tiver uma correlação objetiva com a realidade, mas, se trata de entender a realidade como a compreende e a vive o criador dessas ficções, ou seja, como algo que por muitos lados e muitas dimensões pode exceder o contexto sociocultural, sem por isso o menosprezar ${ }^{15}$.

Julio Cortázar ressalta que Óscar Collazos havia criticado escritores que buscavam uma fusão profunda do verbo com todas as suas possíveis correlações, como é o caso de Vargas Llosa. Na compreensão de Cortázar, o romance revolucionário não é somente o que tem um "conteúdo" revolucionário, senão o que procura revolucionar o próprio gênero, para isso, o escritor utiliza a conjuntura, a trama pluridimensional e a fratura da linguagem ${ }^{16}$. A seu ver, Collazos comete um grave erro quando se levanta contra a afirmação de Vargas Llosa, pois a realidade autônoma que alude o escritor peruano é o laboratório em que um romancista opera a revolução nas palavras e na forma da narrativa ${ }^{17}$. Segundo Cortázar, nenhum dos romancistas citados por Collazos,

têm o menor sentimento de inferioridade frente a cultura estrangeira, nem como criador nem como teorizador, e precisamente porque não o tem é capaz de inventar, aproveitar ou aperfeiçoar as técnicas mais diversas com uma total naturalidade e autenticidade, sem sequer ocorrer-lhe que coincidem ou derivam de experiências literárias estrangeiras. Incluindo, é obvio que os romances latino-americanos mais bem sucedidos nestes anos inovam consideravelmente a respeito das técnicas francesas ou norte-americanas, e que, por exemplo, a admirável estrutura formal de um livro como La casa verde não tem equivalente na Europa nos últimos anos ${ }^{18}$.

A resposta de Óscar Collazos para Julio Cortázar foi uma carta aberta intitulada Contrarrespuesta para armar, na qual expressava concordância com

\footnotetext{
${ }^{14}$ Ibidem, p.50.

${ }^{15}$ Idem. [tradução nossa].

${ }^{16}$ Ibidem, p.73.

${ }^{17}$ Ibidem, p.74.

${ }^{18}$ Ibidem, p.40. [tradução nossa].
} 
seus argumentos, sublinhando que a leitura de Cortázar sobre seu ensaio foi em parte injusta, mas que, de qualquer forma, suas acusações e críticas não se dirigiam a ele, e sim a Vargas Llosa:

[...] quando cito o risco do endeusamento ou a soberba produzida por um pensamento, por um intelectual que se move em esquemas ideológicos que querem dar o mot d'ordre da honestidade ou a definição de uma permanente conduta crítica, não posso deixar de pensar no grande romancista Mario Vargas Llosa dando lições de política internacional e sensatez - a partir de uma tribuna reacionária - a Fidel Castro, quando este apoiou a ocupação ou "invasão" da Tchecoslováquia ${ }^{19}$.

Collazos se refere ao artigo El socialismo y los tanques (1968), de Vargas Llosa, publicado na revista Caretas. Neste artigo, o escritor peruano assinalou sua preocupação em torno da construção do socialismo cubano, condenando o apoio de Fidel Castro à invasão soviética na Tchecoslováquia e a nova política cultural implementada pelo governo cubano. Em uma mesa redonda sobre o tema do intelectual e a revolução, realizada em Havana, em 1969, Roberto Fernández Retamar, então diretor da Revista Casa de las Américas, também reprovou o artigo de Vargas Llosa, concordando com a argumentação de Collazos. Para Fernández Retamar, a doutrina literária, segundo a qual a literatura pode ser crítica mesmo dentro do socialismo, tal como formulada por Vargas Llosa, era contrarrevolucionária, "porque a tarefa do intelectual na sociedade socialista não é a dissensão, senão o fortalecimento do sistema" ${ }^{, 20}$.

Vargas Llosa respondeu as acusações de Collazos, no texto Luzbel, Europa y otras conspiraciones, publicado em abril de 1970, em Marcha. O escritor peruano ressaltou que os dois textos de Collazos, rechaçam ou negam o apogeu literário do romance latino-americano, posicionamento que compreende e aceita, uma vez que, este processo é caótico. Porém, Vargas Llosa acusa Collazos de assumir o papel de caçador de bruxas, detectando nos escritores do chamado boom uma conspiração política reacionária ${ }^{21}$.

\footnotetext{
${ }^{19}$ COLLAZOS, Óscar. "Contrarrespuesta para armar”. In: Literatura en la revolución y revolución en la literatura, op. cit., p.102 [tradução nossa, grifos do autor].

${ }^{20}$ Em Cuba, a revista Casa de las Américas, não escondeu seu apoio a Collazos e às suas ideias sobre o engajamento do escritor. (RETAMAR, Roberto Fernández apud KRISTAL, Efráin. "La política y la crítica literaria. El caso Vargas Llosa". Perspectiva, Universidad de Chile, vol. 4, n. 2, p. 343).

${ }^{21}$ VARGAS LLOSA, Mario. [1970]. "Luzbel, Europa e Outras Conspirações". In: Contra vento e maré. Rio de Janeiro: Francisco Alves, 1985, p.150-151. No que se refere à resposta de Vargas
} 
O escritor peruano - tal qual fizera em sua resposta a Encuesta, realizada durante a Conferência da Tricontinental, em Havana (jan.1966) - sustentou uma percepção distinta entre o criador (escritor) e o intelectual. A seu ver, a natureza da literatura é a rebeldia, independentemente de estar numa sociedade socialista ou capitalista, o elemento crítico é próprio do caráter literário. O escritor peruano, ao indagar-se sobre a problemática acerca das possibilidades de um "casamento" entre o aparato conceitual e a própria obra de um escritor, assinalou que o problema é real, mas não latino-americano como supôs Collazos. Para Vargas Llosa, "trata-se de um problema universal e tão antigo quanto à literatura", podendo ser formulado na seguinte questão: “é possível e desejável que exista uma identidade total entre a obra criadora de um escritor e sua ideologia e moral pessoais?"22. Na percepção de Vargas Llosa, Collazos teria ficado "deprimido" ao constatar que, em muitos casos, havia um divórcio entre "os valores implícitos de uma obra literária e os valores que um autor manifestava objetivamente em seu comportamento social ou político", pois a literatura estabelece "uma inevitável dualidade ou duplicidade". Para ele, o ato da criação nutre-se, simultaneamente e em graus diversos, "das duas fases da personalidade do criador, a racional e a irracional, as convicções e as obsessões, sua vida consciente e sua vida inconsciente" ${ }^{23}$. De acordo com Vargas Llosa, Collazos só destacou os casos de divórcio político, porque era o aspecto que mais lhe interessava, mas, na verdade as contradições ou desavenças entre obra e criador poderiam também estar presentes em todos os outros domínios da experiência humana. Assim, declara Vargas Llosa:

Naturalmente não estou insinuando a falta de identidade do autor com sua obra; só afirmo que no ato da criação há a intervenção de um fator irracional que muitas vezes transtorna e contradiz as intenções e convicções do escritor. O único modo de se eliminar toda possibilidade de antagonismo entre uma obra e seu autor (naturalmente, em alguns casos, não existe este divórcio) seria suprimir toda a espontaneidade na criação literária, reduzindo o trabalho criador a uma operação estritamente racional, onde alguém (o guardião dos valores ideológicos ou morais: a Igreja ou o Estado) determinasse, através de certas normas ou regulamentos, os temas ou o tratamento dos temas, de modo que a obra não se afastasse dos valores entronizados pela sociedade. Isso se intentou, através da Inquisição e através do

Llosa, optamos por utilizar a versão traduzida para o português, publicada no livro Contra vento $e$ maré (1985).

${ }^{22}$ Ibidem, p.152.

${ }^{23}$ Para exemplificar seu argumento, Vargas Llosa citou o caso de "Balzac, partidário da monarquia absoluta, anti-semita e conformista, e criador de uma obra que nos parece hoje um modelo maior de literatura realista crítica". (Ibidem, p.152-153). 
realismo socialista, com os resultados conhecidos: a literatura edificante, super vigiada pelos curas, e a literatura militante, regulada pelos burocratas, significaram a banalidade e quase a extinção da literatura ${ }^{24}$.

Para Collazos, a literatura subversiva deveria existir apenas na sociedade capitalista, pois a sociedade socialista seria livre de contradições. O que Vargas Llosa respondeu com algumas indagações:

[...] Desaparecem, automaticamente, todos os problemas? Já não existem motivos de descontentamento, de discórdia, já não há contradições sociais, políticas, morais e culturais nessa sociedade moralizada pela revolução? É a felicidade o alimento universal e constante de todos os membros da nova sociedade? Nessa utópica sociedade - se existiu alguma vez - a literatura terá desaparecido, pois já não terá razão de ser: reconciliados com a realidade concreta e consigo mesmos, os homens já não terão nenhuma necessidade de erigir realidades verbais nas quais projetem seus "demônios""

O escritor peruano contestou severamente a crítica que Collazos lhe fez por ter discordado do apoio de Fidel Castro à invasão soviética na Tchecoslováquia. Para ele, trata-se de uma contradição, pois ao mesmo tempo em que Collazos discorda da teoria do realismo socialista e da planificação burocrática da criação literária, "rechaça como politicamente perniciosas, as atitudes críticas do escritor para com o poder revolucionário" ${ }^{26}$. Nesse sentido, afirma Vargas Llosa que, o fato de Fidel Castro ter dirigido com heroísmo uma revolução não significava que ele fosse o dono da verdade, a contestação é uma ação crítica ${ }^{27}$.

Para Óscar Collazos as ideias literárias de Vargas Llosa eram reprováveis na medida em que elas instituíam uma total autonomia da arte e do fazer literário. No capítulo IV, veremos que a leitura de Ángel Rama é divergente. Para o crítico uruguaio, a teoria dos "demônios" de Vargas Llosa é alvo de objeções, pois, em certa medida, baseia-se na submissão da criação a um terceiro fator, estritamente psicológico, nomeado pelo escritor peruano como "demônios" do romancista.

\footnotetext{
${ }^{24}$ Ibidem, p. 154

${ }^{25}$ Ibidem, p. 155 .

${ }^{26}$ Idem.

${ }^{27}$ Ibidem, p. 156.
} 


\section{2. \\ O "caso Padilla" e debate o debate intelectual}

A revolução cubana constituiu-se como polo de atração e repulsão da comunidade intelectual. Se por um lado, nos anos iniciais, o programa cultural do governo revolucionário cubano contribuiu em grande medida para reunir em torno de Cuba a intelectualidade de esquerda latino-americana. Por outro, no decorrer do processo de estabelecimento do governo, o recrudescimento das políticas de controle econômico-social e as mudanças de orientação quanto à política cultural, acabaram criando quadros de dissidência entre os antigos apoiadores ${ }^{28}$. Nesse sentido, a metáfora utilizada por Beatriz Sarlo, como referência a problemática dos intelectuais argentinos nos anos 1960-70, pode ser vista como uma marca do sentimento da intelectualidade latino-americana de esquerda no período, uma metáfora dupla: escalada y derrumbe (escalada e colapso) ${ }^{29}$.

Desde 1967, o governo revolucionário cubano começou a enfrentar uma série de problemas que fizeram com que grande parte da intelectualidade latinoamericana de esquerda repensasse a experiência cubana, dificultando a perspectiva de uma revolução em escala latino-americana. Entre outras questões, colaboraram nesse processo: a morte de Che Guevara e de outros guerrilheiros, em 1967; o apoio de Fidel Castro à invasão soviética na Tchecoslováquia e, o alinhamento com a União Soviética, em 1968; e, a crise financeira agravada pelo fracasso do plano político-econômico que tinha como foco o setor açucareiro, em 1970.

De acordo com Adriane Vidal Costa, até 1967 existiu em Cuba um grande debate no qual coexistiram diferentes conceitos de intelectual e engajamento, mas a partir de 1968, com a intensificação do controle político sobre o meio cultural, esta coexistência desapareceu, dando lugar a um discurso normatizador que, enquadrava o intelectual na esfera da Revolução ${ }^{30}$. A realização do I Congresso Cultural de la Habana, em janeiro de 1968, por iniciativa da Casa de las

\footnotetext{
${ }^{28}$ Como exemplo, podemos citar o caso de Severo Sarduy e Guillermo Cabrera Infante, que após o rompimento com o regime cubano exilaram-se na Europa.

${ }^{29}$ SARLO, Beatriz. “Intelectuales: ¿Escisión o mimesis?”. Punto de Vista, n. 25, dez.1985, p.1-6. Disponível em: 〈http://www.ahira.com.ar/revistas/pdv/pdv21.php\#num005>

${ }^{30}$ COSTA, Adriane A. Vidal. Intelectuais, Política e Literatura na América Latina: o debate sobre revolução e socialismo em Cortázar, García Márquez e Vargas Llosa (1958-2005). $413 \mathrm{f}$. Tese (Doutorado em História) - Programa de Pós-Graduação do Departamento de História da Faculdade de Filosofia e Ciências Humanas da Universidade Federal de Minas Gerais, 2009, p. 187-190.
} 
Américas, marcou em definitivo a virada das discussões sobre a função do intelectual na revolução. Durante o congresso, se estabeleceu a noção de que não existiria "atividade intelectual pura", perspectiva que se desdobrou em medidas oficiais que restringiam a liberdade dos artistas e dos intelectuais enquanto formadores de opinião, materializando-se num aprofundamento da estatização dos meios de produção. Nesse sentido, ocorreu o fechamento de editoras independentes e publicações especializadas; o cerceamento a alguns artistas; a recusa dos "vanguardismos" nas artes, visto como uma estética pequeno-burguesa de difícil assimilação pelas massas; a proibição da difusão de obras culturais que criticassem o governo cubano, entre outras medidas ${ }^{31}$.

Como assinala Costa, o I Congresso Cultural de la Habana tinha como propósito articular os princípios que permitiam fazer frente à ofensiva imperialista encabeçada pelos Estados Unidos, e estabelecer um denominador comum de ação, sedimentando as relações entre os intelectuais estrangeiros e cubanos, por meio do engajamento político, colocando as produções culturais a serviço da luta antiimperialista $^{32}$. Durante o congresso, foram organizadas cinco comissões para tratar de temáticas relacionadas à cultura e ao intelectual nos países do Terceiro Mundo. A comissão responsável por abordar o tema sobre a função do intelectual, foi presidida por Fernández Retamar, nomeada como Responsabilidad del intelectual ante los problemas del mundo subdesarrollado, cujo resultado foi a Declaración General, que definiu o "intelectual como um homem de ação que deveria servir a luta revolucionária em diversas frentes: a ideológica, a política e a militar"33.

${ }^{31}$ Sobre as medida do governo cubano e a política cultura em Cuba, ver: VILLAÇA, Mariana Martins. O Instituto del Arte e Industria Cinematográficos (ICAIC) e a política cultural em Cuba (1959-1991). 434 f. 2 v. Tese. FFLCH (Departamento de História), USP, São Paulo, 2006.

${ }^{32} \mathrm{O}$ congresso reuniu mais de quatrocentos intelectuais vindos de mais de setenta países que proclamaram solidariedade com a luta anti-imperialista e com o "heroico povo vietnamita". Um dos compromissos exigidos aos intelectuais, "verdadeiramente revolucionários", era uma total recusa à concessão de bolsas de estudos e à participação em programas culturais ou de pesquisa patrocinados ou incentivados pelos Estados Unidos. O aceite de quaisquer desses benefícios significaria colaboração com a política de colonização cultural norte-americana. Foi durante este congresso que se definiu a aproximação de Cuba, em termos de políticas econômicas e culturais com a URSS. (COSTA, Adriane A. Vidal, op. cit., p.188-189).

${ }^{33}$ As comissões foram organizadas em torno dos seguintes temas: Cultura y independencia nacional, Formación integral del hombre, Responsabilidad del intelectual ante los problemas del mundo subdesarrollado, Cultura y medios de comunicación e Problemas de la creación artística y del trabajo científico y técnico. Distintos escritores contribuíram com textos que, posteriormente, foram publicados pela revista Casa de las Américas, nos quais, figuravam Regis Debray e Che Guevara, como a encarnação do intelectual modelo. (Ibidem, p.189-190). 
As primeiras aproximações de Cuba com a URSS fizeram com que alguns intelectuais se distanciassem do governo cubano, como foi o caso de García Márquez, em 1961. A defesa do socialismo e a amizade com Fidel Castro fizeram com que, em meados dos anos sessenta, o escritor colombiano se aproximasse novamente de Cuba, decretando seu apoio quase que incondicional ao castrismo, convertendo-se, a princípio, em um "amigo" oficial da Revolução que viajava periodicamente para encontrar-se com Fidel Castro em Havana. Quando seu apoio a Cuba se fortaleceu, García Márquez tornou-se um enviado especial das missões político-culturais cubanas. Contraditoriamente, este era o período em que o regime cubano passou pelo chamado processo de "sovietização"34.

Vargas Llosa teve um posicionamento semelhante ao de García Márquez quanto ao receio das aproximações de Cuba com o regime soviético. Entretanto, a intensidade da crítica do escritor peruano e sua consequência posterior divergiram radicalmente. Foi no curso dos acontecimentos de 1968 que Vargas Llosa publicou o artigo El socialismo y los tanques. O escritor peruano teceu críticas ao apoio de Fidel Castro à intervenção militar soviética na Tchecoslováquia, por não compreender as razões que levaram Fidel Castro a este posicionamento, uma vez que até aquele momento, o líder cubano havia defendido a soberania nacional, reivindicando o direito dos pequenos países de realizarem sua própria política sem a intromissão de nenhuma potência. Para Vargas Llosa, o que estava em jogo no drama tchecoslovaco, não era a luta entre o capitalismo e o comunismo, mas o destino dos países que formavam o Terceiro Mundo. A seu ver, a invasão da Tchecoslováquia, no cenário mundial, causou danos gravíssimos às forças de esquerda, agravando a divisão internacional do socialismo, o que levou a direita a usar a seu favor o drama tchecoslovaco. Na França, a União Nacional dos Estudantes, que encabeçou o movimento de maio de 68, "foi a primeira a exortar os seus filiados para saírem às ruas para protestar contra a intervenção militar, ${ }^{, 35}$. Nesse caso, Vargas Llosa viu consequências positivas, pois o exemplo do movimento estudantil francês serviu para mostrar que as organizações de esquerda já não operavam no “antigo maniqueísmo". A adesão ao socialismo já não era

\footnotetext{
${ }_{35}^{34}$ Ibidem, p. 98-99.

${ }^{35}$ VARGAS LLOSA, Mario. [1968]. "O Socialismo e os Tanques". In: Contra vento e maré. Rio de Janeiro: Francisco Alves, 1985, p.160-163.
} 
mais entendida como adesão incondicional à política soviética, tornando as forças progressistas mais "independentes e lúcidas"36.

Segundo Vargas Llosa, foi em 1965, que se iniciou sua contenda com Fidel Castro, por conta da política de perseguição aos homossexuais,

a quem Cuba chamava "os enfermos". Nesse tempo, Castro organizou as Unidades Móveis [sic] de Apoio à Produção, verdadeiros campos de concentração nos quais encerravam os criminosos, porém também os adversários da Revolução, os homossexuais, os hippies, a boêmia artística. Mandava-os trabalhar nas granjas similares aos gulags. Soube de vários suicídios. Foi então que começou minha contenda com Fidel e lhe escrevi uma carta pessoal ${ }^{37}$.

Embora, crítico do governo cubano, principalmente do forte alinhamento com a URSS, Vargas Llosa permaneceu, ao menos neste período, favorável a Cuba, acreditando num reposicionamento do regime cubano. Nos anos posteriores, houve um recrudescimento dos discursos e medidas políticas que cerceavam a liberdade de expressão. Um processo que articulou explicitamente a cultura e o campo político, em muitos casos, criando uma escala de subordinação. Nesse sentido, é expressivo o dossiê Diez años de revolución: el intelectual y la sociedad (1969), organizado pela Casa de las Américas, cujos textos foram assinados por Roque Dalton, René Depestre, Edmundo Desnoes, Roberto Fernández Retamar, Ambrosio Fornet e Carlos María Gutierrez. Segundo Costa:

Se no discurso de Fidel Castro, Palabras a los intelectuales (1961), prevalecia uma relação tripartida do intelectual - revolucionário, não revolucionário e contrarrevolucionário -, no dossiê de 1969 essa relação foi reduzida para duas posições possíveis: revolucionário ou contrarrevolucionário. Nesse dossiê desapareceu por completo o discurso sobre a coexistência entre os diferentes conceitos de intelectual e foi imposta a definição de intelectual orgânico de Gramsci. Com destaque para a semelhança entre a concepção de Gramsci e a de Che Guevara em El hombre y el socialismo en Cuba: os intelectuais maculados pelo "pecado original" e não revolucionários de Che Guevara eram os intelectuais de transição de Gramsci ${ }^{38}$.

A partir deste momento, no campo discursivo, se condicionou a crítica aos aparatos do governo revolucionário. Além disto, a crítica negativa passou a ser identificada como "presunção", sobretudo, se viesse dos intelectuais estrangeiros,

\footnotetext{
${ }^{36}$ Ibidem, p. 163.

37 MICHNIK, Adam. "Dos entrevistas con Mario Vargas Llosa. Optimismo de la historia". In: Cuadernos Hispanoamericanos, Madri, n. 574, abr.1998, p.9. [tradução nossa].

${ }^{38}$ COSTA, Adriane A. Vidal, op. cit., p.191.
} 
uma vez que estes viviam distante dos problemas da ilha, num outro tipo de sociedade e por isso, carente de sentido.

A prisão do poeta Heberto Padilla, em 1971, marcou o final do idílio de muitos intelectuais com a Revolução Cubana ${ }^{39}$. Em outubro de 1968, a Unión Nacional de Escritores y Artistas de Cuba (UNEAC) organizou um concurso, no qual foi eleito por um júri internacional os poemas Los siete contra Tebas (1968) de Atón Arrufat e Fuera del juego (1971) de Heberto Padilla como ganhadores. O Comitê Diretor da UNEAC desaprovou os dois livros por considerá-los politicamente incorretos, ou contrarrevolucionários ${ }^{40}$. Padilla decidiu contestar a decisão do comitê, atitude que se desdobrou com sua detenção em 1971, acusado de atividades contrarrevolucionárias ${ }^{41}$. Depois de permanecer trinta e oito dias detido, Padilla apresentou-se na UNEAC para admitir publicamente "seus desvios". Em seu discurso afirmou que havia cometido erros imperdoáveis, censuráveis e inqualificáveis, e pediu perdão por ter caluniado a Revolução. Além disso, Padilla declarou que a experiência na prisão serviu para convertê-lo em um defensor irrestrito da Revolução, fazendo um apelo para que os intelectuais apoiassem decididamente o processo revolucionário ${ }^{42}$. A prisão de Padilla foi chamada por alguns intelectuais de sectarismo e sua autocrítica compreendida como uma farsa. Enquanto escritores como Alejo Carpentier, Mario Benedetti, García Márquez, entre outros, mantiveram a fé revolucionária, mesmo durante e pós o "caso Padilla", para escritores como Octávio Paz, Carlos Fuentes e Vargas Llosa o caso significou uma quebra de confiança e o início de um processo de rompimento com a Revolução.

\footnotetext{
${ }^{39}$ Padilla nasceu em Cuba, em 1933, dedicou-se a literatura, se destacando como poeta. Estava nos Estados Unidos trabalhando como jornalista quando teve notícia da Revolução Cubana. Padilla aderiu à causa cubana e voltou a viver na ilha, entusiasmado pelos primeiros anos da revolução. Trabalhou para o Estado desempenhando funções diplomáticas na Europa, especialmente na União Soviética até 1966, quando retornou a Cuba. (Germán Albuquerque Fuschini. "El caso Padilla y las redes de escritores latino-americanos". Revista Universum, Chile, Universidade de Talca, n. 16, 2001, p.309).

${ }^{40}$ Fuera del juego foi publicado com o prólogo explicativo do Comitê Diretor da UNEAC, no qual julgava-o por seu distanciamento da Revolução, por sua crítica arbitrária sobre os objetivos e problemas da realidade cubana e, por sua exaltação ao individualismo num momento em que a Revolução requeria ações coletivas para obter metas de transformação social. (COSTA, Adriane A. Vidal, op. cit., p.195).

${ }^{41}$ Para Lisandro Otero, Padilla não foi preso, por ter escrito Fuera del juego, mas por suas colaborações com o fotógrafo francês Pierre Golendorf, um agente disfarçado da CIA em Cuba. Padilla em suas memórias negou a existência do "agente da CIA" e, consequentemente, sua colaboração como informante. (COSTA, Adriane A. Vidal, op. cit., p.195-196).

${ }^{42}$ Ibidem, p.195-196.
} 
Vargas Llosa reagiu quase imediatamente à prisão de Heberto Padilla, assinando uma carta aberta, Declaración de los 54, endereçada ao "Comandante Fidel Castro" e publicada no jornal Le Monde. A carta foi idealizada e redigida por Cortázar e Juan Goytisolo, assinada por intelectuais latino-americanos e europeus, tais como: Carlos Barral, Simone de Beauvoir, Ítalo Calvino, Fernando Claudín, Marguerite Duras, Hans-Magnus Enzensberger, Carlos Franqui, Carlos Fuentes, Maurice Nadeau, Octavio Paz, Jean-Paul Sartre, Susan Sontag, entre outros. No texto, os signatários expressaram sua solidariedade aos princípios e objetivos da Revolução Cubana, mas solicitavam uma explicação da situação criada pela detenção de Padilla. Desse modo, considerava-se que:

O emprego de métodos repressivos contra intelectuais e escritores que tenham exercido o direito de crítica dentro da revolução, pode ter apenas uma repercussão profundamente negativa entre as forças anti-imperialistas do mundo inteiro e muito especialmente na América Latina, onde a Revolução Cubana é um símbolo e uma bandeira. Agradecendo a atenção concedida a este pedido, reafirmamos a V. [Fidel Castro] a nossa solidariedade com os princípios que guiaram a luta na Sierra Maestra e que o Governo Revolucionário de Cuba tantas vezes exprimiu através da palavra e da ação do seu Primeiro Ministro, do Comandante Che Guevara e de tantos outros dirigentes revolucionários ${ }^{43}$.

Fidel Castro reagiu contra a crítica destes intelectuais no discurso pronunciado durante o Congreso Nacional de Educación y Cultura (1971), no qual afirmou que os intelectuais estrangeiros espalhavam "o veneno, a insídia e a intriga na Revolução" e, como se não bastasse, eram ainda, "agentes do colonialismo cultural", "inteligências do imperialismo", "agentes da CIA”. Fidel Castro ressaltou que alguns destes intelectuais estrangeiros eram "latinoamericanos, que em vez de se colocarem em uma trincheira de combate", viviam nos "salões burgueses a milhas dos problemas, usufruindo um pouquinho de fama que ganharam quando, durante um período, foram capazes de expressar alguns dos problemas latino-americanos". Como medida política, o Primeiro Ministro cubano decidiu fechar as fronteiras aos intelectuais estrangeiros, por tempo "indefinido e infinito". Neste discurso, Fidel Castro afirmou a necessidade de que os intelectuais revolucionários escrevessem sobre temas da Revolução em sua luta contra o subdesenvolvimento. Para ele, no campo da luta ideológica, não cabiam paliativos ou meio termo, a única alternativa era assumir posições claras e

\footnotetext{
${ }^{43}$ Ibidem, p.197-198.
} 
precisas. A responsabilidade do intelectual, a seu ver, era a de ajudar a despertar a consciência crítica do povo, participando da difícil tarefa de defender a revolução, dividindo com o povo todos os riscos, como fizeram José Martí e Che Guevara trocando a "trincheira de ideias" pela "trincheira de pedras"44. Outra medida adotada pelo governo cubano foi fazer circular na Prensa Latina uma versão datilografada da autocrítica de Padilla.

Estas medidas acirraram os ânimos e a desconfiança da comunidade intelectual para com o governo cubano. Nesse sentido, outra carta, Declaración de los 62, foi endereçada a Fidel Castro em 1971, desta vez, a carta passou do tom cauteloso da primeira a uma clara reprovação da política cubana, afirmando que a autocrítica de Padilla era uma farsa e havia sido fruto de métodos "que são a negação da legalidade e justiça revolucionária”. Na visão dos signatários da carta, a confissão de Padilla os fazia recordar "os momentos mais sórdidos da época do stalinismo, os seus julgamentos fabricados e as suas caças às bruxas" ${ }^{45}$. O texto foi redigido por Vargas Llosa e assinado por Claribel Alegría, Simone de Beauvoir, Italo Calvino, Hans Magnus Enzensberger, Carlos Fuentes, Juan Rulfo, Jean-Paul Sartre, Nathalie Sarraute, Juan e Luis Goytisolo, entre outros ${ }^{46}$.

Após assinar a Declaración de los 54, Vargas Llosa enviou uma missiva para Haydée Santamaría, onde solicitou seu desligamento do Comitê da revista Casa de las Américas, no qual fazia parte desde 1965. O escritor peruano comunicou, também, sua decisão de não se deslocar a Cuba para realizar o curso em janeiro, no qual havia se comprometido:

[...] Compreenderá que é a única coisa que posso fazer depois do discurso de Fidel fustigando os "escritores latino-americanos que vivem na Europa", aos quais proibiu a entrada em Cuba "por tempo indefinido e ilimitado". [...] Como mudaram os tempos: lembro-me muito bem da noite que passamos com ele, há quatro anos, na qual aceitou de boa vontade as observações e críticas que nós, um grupo desses "intelectuais estrangeiros", lhe fizemos, e agora nos chama de "canalhas" ${ }^{47}$.

\footnotetext{
${ }^{44}$ Disponível em: <http://www.cuba.cu/gobierno/discursos/1971/esp/f300471e.html>

${ }^{45}$ A carta foi finalizada com uma ressalva: "Gostaríamos que a Revolução Cubana voltasse a ser o que num dado momento nos levou a considerá-la como modelo dentro do socialismo". (VARGAS LLOSA, Mario. [1971]. "Carta a Fidel Castro”. In: Contra vento e maré. Rio de Janeiro: Francisco Alves, 1985, p.167-168).

${ }^{46}$ Essa carta não contou com a adesão de Cortázar e do editor Carlos Barral, que declararam posições favoráveis a Cuba. Em abril de 1972, Cortázar enviou uma carta para Vargas Llosa na qual solicitava que seu nome fosse retirado da lista de colaboradores da revista Libre para que não tivesse mais problemas com Cuba. Sobretudo, porque nesta revista circulou grande parte da crítica dos intelectuais latino-americanos que viviam na Europa à detenção e autocrítica de Padilla. (COSTA, Adriane A. Vidal, op. cit., p. 224-225).

${ }^{47}$ Mario. [1971]. "Carta a Haydée Santamaría”. In: Contra vento e maré, op. cit., p.165-166.
} 
Em sua resposta, publicada na revista Casa de las Américas, Haydée Santamaría referiu-se a Vargas Llosa como um dos "piores caluniadores" da revolução cubana, citando o "caso Padilla" e outras divergências com a revolução, para acusar Vargas Llosa de nunca ter sido um autêntico revolucionário ${ }^{48}$. Em entrevista concedida a César Hildebrandt, Vargas Llosa preferiu não responder as acusações de Santamaría, pois considerava que polemizar ao "nível das invenções era inútil e empobrecedor" ${ }^{\prime 9}$. Na entrevista, o escritor peruano afirmou que as autocríticas de Herbeto Padilla, Pablo Armando Fernádez, Belkis Cuza Malé, César López e Manuel Díaz Martínez, acusando-se de traições imaginárias, e as alarmantes declarações de Fidel Castro sobre a cultura em geral, manchavam a imagem da revolução, pois contradiziam o que sempre havia admirado na revolução cubana: "haver mostrado que a justiça social era possível sem depreciar a dignidade dos indivíduos, sem ditadura policial ou estética"50. Para Vargas Llosa, assim como ocorrido em outras ocasiões em que Fidel Castro retificou os erros cometidos, uma postura similar poderia colocar o episódio como algo "passageiro" e não como estreitamento de uma política cultural dogmática e repressiva.

A imprensa explorou amplamente as contendas em torno do "caso Padilla". Ação que levou Vargas Llosa a declarar sua desaprovação a respeito do uso feito pela imprensa de suas declarações, principalmente a imprensa de direita que se mostrava empenhada em tirar partido dos acontecimentos na campanha contra o socialismo cubano e a revolução latino-americana. Nesse sentido, o escritor peruano, enviou a Prensa Latina uma declaração explicando sua renúncia do comitê da Casa de las Américas:

\footnotetext{
${ }^{48}$ Haydée Santamaría relembrou o episódio do prêmio Rómulo Gallegos, recebido por Vargas Llosa, em 1967, outorgado pelo governo venezuelano de Leoni, "que significava assassinatos, repressão, traição aos nossos povos". Segundo Santamaría, já nesta época, Vargas Llosa dava indícios de que não era um autêntico revolucionário, pois se recusou a entregar o dinheiro recebido pelo prêmio à "extraordinária honra de poder contribuir, simbolicamente, para auxiliar a luta de Che Guevara". "Respuesta de Haydée Santamaría a Mario Vargas Llosa". (COSTA, Adriane A. Vidal, op. cit., p.208). Anos depois, em entrevista concedida a Ricardo Setti, Vargas Llosa contestou a versão de Santamaría, explicando que, em 1967, Alejo Carpentier lhe entregou uma carta dela apresentando uma proposta da doação "fictícia" do dinheiro, pois "a Revolução the devolveria o dinheiro discretamente, sem que ninguém ficasse sabendo". Vargas Llosa considerou tal proposta ofensiva, uma farsa na qual um escritor que tem respeito por seu trabalho não poderia aceitar. SETTI, Ricardo. Conversas com Vargas Llosa. São Paulo: Brasiliense, 1986, p.146.

${ }^{49}$ VARGAS LLOSA, Mario. [1971]. "Entrevista exclusiva a V.LL." In: Contra viento y marea I (1962-1972). Barcelona: Seix Barral, 1986, p.255.

${ }^{50}$ Ibidem, p.254.
} 
Certa imprensa está usando minha renúncia ao comitê da revista Casa de las Américas para atacar a revolução cubana a partir de uma perspectiva imperialista e reacionária. [...] Minha renúncia é um ato de protesto contra um fato específico, que continuo considerando lamentável, mas não é nem pode ser um ato hostil contra a Revolução Cubana, cujas realizações formidáveis para o povo de Cuba são efetuadas em condições verdadeiramente heroicas, que pude constatar pessoalmente nas frequentes viagens que fiz à ilha. $\mathrm{O}$ direito à crítica e à divergência não é um privilégio burguês. Ao contrário, só o socialismo pode assentar as bases de uma verdadeira justiça social, dar o verdadeiro sentido a expressões como liberdade de opinião, liberdade de criação. Foi no exercício desse direito socialista e revolucionário que discordei do discurso de Fidel sobre o problema cultural, que critiquei o que sucedeu com Heberto Padilla e outros escritores. Fiz por ocasião dos acontecimentos na Tchecoslováquia, e continuarei fazendo cada vez que julgar necessário, porque essa é minha obrigação como escritor. Mas que ninguém se engane: com todos os seus erros, a Revolução Cubana é, mesmo hoje, uma sociedade mais justa que qualquer outra sociedade latino-americana, e defendê-la contra seus inimigos é para mim um prazer premente e honroso ${ }^{51}$.

Na entrevista concedida a Leoncio Reynaldo Trinidad, também em 1971, Vargas Llosa ao falar do "caso Padilla" declarou que sua solidariedade a Revolução Cubana, nunca foi incondicional. Para ele, a primeira obrigação do escritor era a crítica da realidade que o rodeia ${ }^{52}$. Nesta entrevista, ao ser questionado sobre qual tipo de socialismo ele escolheria para superar o subdesenvolvimento dos povos do Terceiro Mundo, o da União Soviética, o da China, o de Cuba ou o da Iugoslávia, Vargas Llosa respondeu indagando porque o entrevistador não havia mencionado o Chile, de Salvador Allende, pois concebia a experiência chilena autêntica em vários sentidos. Para o escritor peruano, tanto na experiência chilena, como na da Tchecoslováquia de Dubcek, durante a Primavera de Praga, foi possível presenciar uma intensa e otimista participação social, na qual reinava a liberdade quase irrestrita. Para Vargas Llosa, essas experiências eram modelos de socialismo e demonstravam que este não era incompatível com a liberdade. A seu ver, o socialismo não deveria estar dissociado da liberdade seja esta de imprensa ou dos organismos representativos ${ }^{53}$.

$\mathrm{Na}$ compreensão de Vargas Llosa, o escritor deveria contribuir com o esclarecimento dos problemas sociais, através de um aclaramento de sua realidade, escrevendo com o máximo rigor e sinceridade. Dessa forma, ao não limitar sua escrita, o escritor estaria cumprindo uma função cívica: “opinar e

\footnotetext{
${ }^{51}$ Ibidem, p.255-256.

${ }^{52}$ REYNALDO TRINIDAD, Leoncio.“Quiero volver a Cuba!”. In: COAGUILA, Jorge (comp.). Mario Vargas Llosa: entrevistas escogidas. Lima: Fondo Editorial Cultura Peruana, 2004, p.74.

${ }^{53}$ Ibidem, p.75.
} 
participar na vida de sua sociedade". Porém, sua principal contribuição seria "o que escreve e não o que opina",54.

Distintos escritores-intelectuais condenaram publicamente as ações do governo cubano no "caso Padilla". Octavio Paz, por exemplo, considerou que a autocrítica de Padilla representava um pesadelo para a história e um cisma literário, comparou o episódio ao stalinismo, que obrigava os seus inimigos a se declararem culpados de "insensatas conspirações internacionais" para defender a sobrevivência da URSS ${ }^{55}$. Para Ángel Rama, o "caso Padilla" poderia ser compreendido dentro dos marcos de burocratização do campo cultural, que havia se iniciado em Cuba, desde 1968. Segundo ele, a autocrítica de Padilla foi uma peça montada, uma fraude anacrônica no plano histórico, pois esse tipo de autocrítica "teve a sua hora na década de trinta" na URSS, "quando foi capaz de convencer a muitos". Porém, sua repetição mais de trinta anos depois era algo grotesco que "parecia dar razão a Marx sobre as diferentes formas que um mesmo evento pode assumir em diferentes tempos históricos" $"$.

A revista Casa de las Américas, reagiu às declarações contrárias a Cuba, publicando uma série de cartas de intelectuais favoráveis ao governo cubano, dentre os quais estavam: os uruguaios Hugo Achugar, Juan Carlos Onetti, Cristina Peri Rosi, Mario Benedetti; os cubanos Alejo Carpentier, Fernández Retamar, Nicolás Guillén; os chilenos Manuel Rojas, Antonio Skármeta, Miguel Littin; os colombianos Carlos Castañeda, Javier Ayala, Ricardo Samper; os equatorianos Darío Moreira, Carlos Arauz, Rolando Montesinos; os mexicanos David Alfaro Siqueiros, Arturo Bonilla, Ricardo Pozas ${ }^{57}$.

O próprio editorial da revista Casa de las Américas atacava claramente os intelectuais que viviam na Europa e a imprensa mundial. Nesta direção estão as publicações de alguns artigos que reinterpretavam antigos ensaios e romances de Vargas Llosa. Ou ainda, análises de críticos e escritores que (re) valoravam negativamente as ficções e concepções teóricas do escritor peruano a partir do rechaço à suas ideias políticas. Conforme assinala Efrain Kristal, neste período as

\footnotetext{
${ }^{54}$ Ibidem, p.76.

${ }^{55}$ PAZ, Octavio apud COSTA, Adriane A. Vidal, op. cit., p.200.

${ }_{57}^{56}$ RAMA, Ángel apud COSTA, Adriane A. Vidal, op. cit., p.202-203.

${ }^{57}$ Diversas declarações favoráveis a Cuba foram publicadas pela revista Casa de las Américas, dentre as quais: Declaración de los cineastas cubanos, Declaración de la UNEAC, Declaración de intelectuales y artistas uruguayos, Declaración de los intelectuales chilenos, Mensaje de los intelectuales colombianos, Cable de intelectuales ecuatorianos e Declaración de intelectuales mexicanos.( COSTA, Adriane A. Vidal, op. cit., p.200).
} 
pautas da recepção crítica da narrativa latino-americana foram marcadas por um tipo de crítica literária política, tornando contraditórios os juízos de valor que se modificavam de acordo com as posições políticas dos autores ${ }^{58}$. De acordo com Vargas Llosa, o rompimento com Cuba, nesse período, lhe rendeu uma "chuva de injúrias" e hostilidades: "Depois de ter sido uma figura muito popular nos meios de esquerda e nos meios rebeldes, passei a ser um empesteado. As mesmas pessoas que me aplaudiram com grande entusiasmo quando eu ia proferir uma conferência passaram a me insultar, distribuíam panfletos contra mim [...]"59.

Nesse sentido, é sintomática a mudança de opinião do crítico literário colombiano Carlos Rincón quanto às ideias e romances de Vargas Llosa. Em 1968, Rincón havia elogiado a composição narrativa de La ciudad y los perros (1963), como enfrentamento da falsa imagem da sociedade peruana, representando as hierarquias de classe, a mitologia militar e a decadência moral no colégio Leoncio Prado ${ }^{60}$. Em 1971, Rincón passou a criticar a composição narrativa e a ideia de Vargas Llosa a respeito da separação entre a vocação literária de um escritor e seu compromisso político. A seu ver, tratava-se de uma proposição "idealista", "anacrônica" e de brutas reduções, com as quais Vargas Llosa operava uma leitura burguesa do romance. Como exemplo, o crítico colombiano citou a leitura de Vargas Llosa do romance Tirant lo Blanc (1490) de Joanot Martorell, na qual refletia suas "próprias preocupações". Além disso, Rincón criticou a simpatia de Vargas Llosa pelo conceito flaubertiano de literatura por representar uma estética burguesa, sendo a metáfora do escritor em competição com Deus correspondente às necessidades ideológicas desta classe ${ }^{61}$. Por fim, Rincón acusou Vargas Llosa de "ecletismo oportunista”. Para ele, as deficiências teóricas de Vargas Llosa aplicavam-se a suas ficções: "o estudo das teses histórico-literárias, críticas e da poética de um romancista, definidas na relação com esse sistema, servem, também, em último termo para determinar qual é seu caráter não como teórico, senão precisamente em quanto romancista" ${ }^{62}$.

58 KRISTAL, Efrain. "La política y la crítica literaria. El caso Vargas Llosa". Perspectiva, Universidad de Chile, vol. 4, n. 2, 2001, p.341.

${ }^{59}$ SETTI, Ricardo. Conversas com Vargas Llosa. São Paulo: Brasiliense, 1986, p.144.

${ }^{60}$ RINCÓN, Carlos apud KRISTAL, Efrain, p.356.

${ }^{61}$ Carlos Rincón, no ensaio de 1968, afirmava que a leitura de Flaubert, entre outros autores, havia contribuído para que Vargas Llosa encontrasse um meio literário eficaz para denunciar a sociedade capitalista latino-americana, sendo o romance La ciudad y los perros uma afronta aos grupos dominantes do Peru. (RINCÓN, Carlos apud KRISTAL, Efrain, op. cit., p.345).

${ }^{62}$ Ibidem, p.346. 
De acordo com Efrain Kristal, o questionamento do conteúdo político dos romances de Vargas Llosa, ressuscitava a tese de Jorge Lafforgue que, no ensaio La ciudad y los perros, Novela moral (1969), argumentou que os primeiros romances de Vargas Llosa eram do ponto de vista ideológico, um embuste porque contribuíam para consolidar a sociedade que pretendiam denunciar ${ }^{63}$. Esta análise foi recuperada e endossada por Antonio Cornejo Polar ao declarar que os romances de Vargas Llosa eram "uma variante do fetichismo da mercadoria". Para ele, a narrativa de Vargas Llosa fornecia uma imagem da sociedade nacional como "espaço de inevitável degradação humana", em última instância, "produzia uma atitude cética que se desligava de suas contradições de base" ${ }^{64}$. Para o peruano Mirko Lauer, Vargas Llosa era um escritor liberal que tinha se "aproveitado" da Revolução Cubana para "estabelecer seu prestígio literário". A seu ver, Vargas Llosa abandonou a esquerda quando seus livros conquistaram o mercado nos "meios colonizadores da Europa e dos Estados Unidos", desde então, sua atividade política vinha sendo um "exercício indiscriminado de conservadorismo" 65 .

De acordo com Efrain Kristal, a participação protagonista de Vargas Llosa no "caso Padilla", precipitou o rechaço nos meios de esquerda de sua obra literária, desenvolvendo-se em três etapas: A primeira foi uma agressiva reprimenda política por seu comportamento contrarrevolucionário; as outras duas se deram no âmbito literário: "se condenaram suas ideias literárias e logo seus romances" ${ }^{, 66}$. Kristal citou, entre os críticos que mudaram de perspectiva sobre as concepções literárias e os romances de Vargas Llosa, Roberto Fernández Retamar, Óscar Collazos, Mirko Lauer, Washington Delgado, Carlos Rincón, Jorge Lafforgue, e Ángel Rama. Sobre este último, Kristal citou a polêmica entre Rama e Vargas Llosa, a respeito da teoria dos "demônios", em 1972, cujos artigos foram publicados no semanário Marcha. Consideramos que, embora no debate apareça à

\footnotetext{
${ }^{63}$ A análise de Lafforgue foi duramente crítica em 1969, chegando ao ponto do próprio autor realizar em seu artigo um post-scriptum se desculpando por ter escrito seu ensaio antes de ler as avaliações de Ángel Rama e outros críticos mais progressistas. (Ibidem, p.348-349). Ángel Rama afirmava, no artigo De cómo sobreviene lo humano, que a aparição de La ciudad y los perros era "um sintoma, entre outros, da próxima revolução: uma revolução das consciências". (RAMA, Ángel. "De como sobreviene lo humano". Marcha, Montevidéu, n.1194, fev.1964, p.29.

${ }^{64}$ CORNEJO POLAR, Antonio. "Hipótesis sobre la narrativa peruana última". In: La novela peruana. $2^{\mathrm{a}}$ ed. Lima: Editorial Horizonte, 1989, p. 272.

${ }^{65}$ LAUER, Mirko apud KRISTAL, Efrain, op. cit., p.349.

${ }^{66}$ Ibidem, p.344.
} 
perspectiva política ${ }^{67}$, não se trata de um rechaço às concepções do escritor peruano pelo viés de seus posicionamentos políticos, senão pelo debate travado nestes anos pela crítica literária acerca de repertórios e metodologias interpretativas.

Progressivamente Vargas Llosa afastou-se de Cuba e depois do socialismo, refutando todos os seus pressupostos teóricos. Na década de oitenta, assumiu uma acepção da liberdade em termo liberal e passou a ser um defensor do neoliberalismo. Posição, defendida em seu programa de governo, como candidato a Presidência do Peru, em $1990^{68}$. Para o escritor peruano, o problema na América Latina não era puramente econômico. A diversidade ideológica, a garantia das liberdades individuais e de crítica, deveria ser tão importante como a eliminação das diferenças sociais, pois isso garantia a fiscalização do poder contendo seus abusos. Suas maiores influências já no final da década de setenta, passaram a ser Ludwig von Mises, Karl Popper, Friedrich Hayek e Isaiah Berlin, que fundamentam sua visão liberal de mundo e sua compreensão da crise das esquerdas.

\footnotetext{
${ }^{67}$ Um exemplo desta questão é, quando Vargas Llosa ressalta: a "chantagem ideológica de uma nova inquisição surgida no seio da esquerda (já não falo de Ángel Rama, esta é uma digressão da atualidade) tende cada dia mais, a impedir o debate cultural na América Latina, a tornar impossível, através do amedrontamento e o ucasse, a fértil divergência, a entronizar dois ismos tão inumanos como abjetos: o oportunismo e o dogmatismo, e a fomentar o espírito policial entre os escritores [...]." (VARGAS LLOSA, Mario. [1972]. "Ressurreição de Belzebu, ou a dissidência criadora". In: Contra vento e maré, op. cit., p.198).

${ }^{68}$ Seu programa de governo, em 1990, propunha, entre outras, as seguintes reformas: "sanear as finanças públicas, acabar com a inflação e abrir a economia peruana para o mundo, como parte de um projeto integral de desmantelamento da estrutura discriminatória da sociedade, removendo seus sistemas de privilégios, de modo que os milhões de pobres e marginalizados pudessem finalmente aceder àquilo que Hayek chama 'a trindade inseparável da civilização': a legalidade, a liberdade e a propriedade". Contemplando ainda, a privatização das empresas estatais. (VARGAS LLOSA, Mario. Peixe na Água. São Paulo: Companhia das Letras, 1994, p.519).
} 


\section{5. \\ A Polêmica Ángel Rama e Mario Vargas Llosa: pensamento crítico e modernização literária}

A polêmica entre Vargas Llosa e Ángel Rama a respeito do livro Gabriel García Márquez: historia de un deicidio (1971) evidencia dois projetos intelectuais distintos. Questões como o papel político-social da literatura, a função do escritor e metodologias de análise crítica permearam as páginas dos artigos que deram sustentação ao debate, chegando a adquirir notas ácidas. Trata-se de uma temática importante na trajetória intelectual de ambos os polemistas que, ao longo da discussão, atravessam o pensamento sobre a modernidade latino-americana e seu sistema cultural. Observa-se no repertório utilizado o desenvolvimento de ideias que já haviam sido articuladas pelos autores em textos anteriores à década de setenta, como também em textos que seriam publicados posteriormente. Mostraremos as principais questões e interpretações que nutriram o debate, estabelecendo os diálogos e movimentos que constituíram o pensamento de ambos os autores.

\section{1. \\ Entre o regresso dos "demônios" e o escritor como produtor}

A polêmica entre Vargas Llosa e Ángel Rama ocorreu nas páginas do semanário Marcha, em 1972. O debate teve origem com a resenha de Rama - a respeito do livro Gabriel García Márquez: historia de un deicidio (1971) intitulada "Demonio vade retro" (n.1591, mai.1972), na qual o crítico uruguaio reprova a teoria dos "demônios" desenvolvida por Vargas Llosa, dando início a uma profícua discussão em torno das problemáticas do romance - suas metodologias de análise, repertório crítico e os fatores que condicionam a criação ${ }^{1}$. São concepções distintas sobre a literatura e sua especificidade no contexto latino-americano que, entre réplicas e tréplicas, iluminam o contraste

\footnotetext{
${ }^{1}$ Em ordem cronológica, os artigos que compõem esta polêmica são: resenha de Rama, Demonio vade retro (n.1591, mai.1972); resposta de Vargas Llosa, El regreso de Satán (n. 1602, jul.1972); réplica de Rama, El fin de los demonios (n. 1603, jul.1972); e as tréplicas de Vargas Llosa, Resurrección de Belcebú o la dissidência creadora (n. 1609, set.1972), e Rama, Segunda respuesta a Mario Vargas Llosa (n. 1610, set.1972). Todos os textos em torno desse debate estão reunidos no livro García Márquez y la problemática de la novela. Buenos Aires: Corregidor Marcha, ediciones, 1973.
} 
entre as duas leituras e o horizonte das urgências teórico-metodológicas no exercício da crítica literária da época. De um lado, Rama afirmava o postulado da literatura enquanto produção social. Por outro, Vargas Llosa comprometia-se com a literatura como trabalho especializado, afirmando a produção de um espaço específico do romance.

Como vimos no capítulo II, a "teoria dos demônios" formulada por Vargas Llosa consiste na compreensão de que a vocação do romancista nasce do desacordo de um homem com o mundo, transformando o escritor num "deicida", um suplantador de Deus que recria a realidade através de mundos verbais. Nesse sentido, a raiz da vocação do romancista seria um sentimento de insatisfação com o "mundo real" tal como este lhe é dado, onde o escritor extravasaria a subjetividade mais restrita para um plano objetivo da realidade. Assim, o escritor seria um ser afligido por "demônios", uma espécie de "obsessão", que poderia ser desenvolvida por questões pessoais, históricas e/ou culturais. Após esta ruptura com a "realidade real", de acordo com Vargas Llosa, o romancista tornaria este processo racional. Trata-se de uma segunda fase, onde o escritor liberta ou "exorciza" seus "demônios" dotando-os de forma, através de métodos e estratégias narrativas, convertendo sua matéria subjetiva em temas concretos, influxos objetivos e universais.

Embora Ángel Rama tenha considerado surpreendente o livro Gabriel García Márquez: historia de un deicidio $(1971)^{2}$ pela atenção incomum que Vargas Llosa dedica a outro narrador de sua época, consagrando um volumoso trabalho a seu colega García Márquez, e pelo refinamento de sua análise técnica muito pessoal, o crítico uruguaio declarou em "Demonio vade retro" que a tese do escritor peruano lhe parecia carecer de fundamentação crítica. Assim, Rama toma para si a tarefa de elucidar o que considerava ser de um "assombroso arcaísmo" crítico, advertindo para os possíveis "prejuízos" derivados da teoria dos “demônios" para as letras latino-americanas ${ }^{3}$.

Ángel Rama não foi o único a reprovar a teoria dos "demônios" como método de análise válido. Em 1969, Óscar Collazos, partindo de uma concepção de cunho político-ideológico, censurou as formulações de Vargas Llosa em torno

\footnotetext{
2 Sobre a história e as condições de produção dessa obra, consultar o capítulo I.

3 RAMA, Ángel. "Demonio vade retro". In: García Márquez y la problemática de la novela. Buenos Aires: Corregidor - Marcha, ediciones, 1973, p.7.
} 
da autonomia literária e seu conceito de realidade na literatura, sobretudo por compreender que se tratava de um distanciamento do contexto sociocultural e político latino-americano ${ }^{4}$. No limiar da década de setenta grande parte do debate crítico esteve pautado em torno da noção de modernização, tendo implicações nas discussões sobre método, linguagem e teorias condizentes com as novas necessidades de interpretações dos mundos simbólicos afetados pelas transformações sociais. Neste sentido, críticos como Wolfgang Luchting, José Luis Martín, Luis Hauss, Julio Ortega e Rosa Boldori de Baldussi questionaram a utilidade da teoria dos "demônios", utilizando uma terminologia que a classificava como "antiquada", "individualista", "romântica", "perigosa" e/ou "anacrônica"5. Assim, Jorge Aguilar Mora - historiador, escritor e crítico literário mexicano declarou:

O livro de Vargas Llosa não somente me parece um grande fracasso, me parece também um livro muito perigoso [...] Digo perigoso porque Vargas Llosa pretende justamente reunir os três tipos de crítica sem o menor rigor, sem o mínimo compromisso intelectual; porém contribuindo em troca com a pobreza da teoria literária na América Latina com termos anacrônicos, com definições retóricas absolutamente inúteis, com afirmações ambíguas que nunca dizem claramente todas as implicações que querem produzir [...]. Em efeito, em conjunto o livro "Historia de un deicidio", de Vargas Llosa, me parece uma fraude, uma obra crítica - se o é - deplorável e perigosa: porque se aproveita de nossa pobreza crítica para propormos ideias retrógradas, contraditórias, termos falsos, lugares comuns. ${ }^{6}$

Aguilar Mora criticou, principalmente, o uso do método biográfico como cerne do estudo de Vargas Llosa, destacando a demasiada relevância concedida à metáfora do escritor em competição com Deus e a omissão da linguagem como centro da análise literária. Por sua vez, com um posicionamento distinto, o espanhol Joaquín Marco ressaltou que a análise de Vargas Llosa contribuía para uma compreensão do panorama do romance contemporâneo hispano-americano, fazendo ressalvas à carência de conotações ideológicas no ensaio ${ }^{7}$. Esse contraste

\footnotetext{
${ }^{4}$ COLLAZOS, Óscar. La encrucijada del lenguaje. In: Literatura en la revolución y revolución en la literatura. México: Siglo XXI, 1970, p. 28-29. Compreendemos esta reprimenda de Collazos como o primeiro debate crítico em torno da ideia dos "demônios" associados à vocação do romancista e da imagem do escritor em disputa com a realidade. Sobre esta polêmica que envolveu Vargas Llosa, Collazos e Julio Cortázar, consultar o capítulo III.

5 SÁNCHEZ, Pablo. La emancipación engañosa: Una crónica transatlántica del boom (19631972). Murcia: Cuadernos de América sin nombre, n. 25, 2009. p.347-348.

${ }^{6}$ AGUILAR MORA, Jorge apud RAMA, Ángel. "Segunda respuesta a Mario Vargas Llosa". In: García Márquez y la problemática de la novela. Buenos Aires: Corregidor - Marcha, ediciones, 1973. p. 66-67. [tradução nossa].

${ }^{7}$ MARCO, Joaquín. Nueva literatura en España y en América. Barcelona: Lumen, 1972. p.306.
} 
de leituras evidencia as diferenças nos modos de organização dos aparatos críticos em ambos os lados do oceano, pautando-se, no caso latino-americano, pelo grau de urgência de uma política emancipadora que corroborava na validação ou não de uma teoria literária. Ángel Rama, em suas considerações, torna evidente esta questão ao afirmar que, "apesar dos desajustes diacrônicos da cultura latinoamericana, [a teoria dos 'demônios'] não entra em seus projetos de expansão, nem nas linhas da evolução universal”, pois não é possível operar uma leitura coerente da arte moderna com um método que corresponde a um século passado ${ }^{8}$.

Para Rama, Vargas Llosa apela a uma cosmovisão tradicionalista para definir a natureza do escritor, promulgando uma percepção irracional do fazer criativo e subsequentemente da análise crítica, que seria originária das concepções filosóficas idealistas do século XIX. Nas palavras de Ángel Rama, “[...] contrariando a ideia da arte como trabalho humano e social, que aporta o marxismo, Vargas Llosa reedifica a tese idealista da origem irracional (se não divina ao menos demoníaca) da obra literária"”. Na concepção do crítico uruguaio, é insólita a reposição de um conceito da estética romântica "nesta segunda metade do século XX", dado que este tipo de crítica "se interessou mais na gênese psíquica da arte que na obra mesma, tal como antes e depois caracterizou a estética ao abandonar o individualismo restrito e agônico dos românticos"10.

Na perspectiva de Ángel Rama, se num escritor como Vargas Llosa, "tão contaminado da ambição do "moderno", sobrevive uma concepção estética "tão velha e caduca", isto poderia significar que "todo nosso continente pode definir-se ainda pelo verso rubendariano: 'Quem não é romântico?' ”, ou seja, que segue vivendo no que Rama chama de "infância cultural" ${ }^{11}$. A seu ver, a revisão e o abandono dessa visão do escritor - "o escritor inspirado, o escritor protegido das musas, o escritor da intimidade terrível e sagrada, o escritor possuído pelos demônios, o escritor irresponsável, portanto, o escritor criança ou louco, como disse Karl Jaspers" -, nem sequer necessitaria de uma substituição do sistema, pois o desenvolvimento e a complexidade crescente das bases econômicas, assim como a aparição de grupos sociais, elevaram novas demandas, estruturando "há

\footnotetext{
${ }^{8}$ RAMA, Ángel. "El fin de los demonios". In: García Márquez y la problemática de la novela. Buenos Aires: Corregidor - Marcha, ediciones, 1973. p. 28.

9 RAMA, Ángel. "Demonio vade retro". In: García Márquez y la problemática de la novela. Buenos Aires: Corregidor - Marcha, ediciones, 1973. p.8.

${ }^{10}$ Ibidem, p.8-9.

${ }^{11}$ Ibidem, p.9.
} 
muito tempo" um novo conceito de escritor. Para Rama, este novo conceito teria assimilado o escritor como um produtor, uma vez que sua visão de como se cria a realidade deixou de ser teológica e passou a ser a de uma nova sociedade manufatureira, baseada no trabalho produtivo ${ }^{12}$. Dessa forma, Rama considera que

algo disto pode ser encontrado na criação de García Márquez a partir de El coronel no tiene quien le escriba (1961), pela qual não parece ser a obra mais adequada para exemplificar uma tese romântica sobre a arte, e, quiçá este livro teria ganhado em precisão se tivesse sido intitulado: "Mario Vargas Llosa: historia de un deicidio”. Embora, também aqui discordássemos. Se Vargas Llosa põe a gênese da criação no irracionalismo, não pode, sem dúvida, situar nesse campo, como seus percussores românticos, a operação da escritura, posto que a tecnificação da arte moderna, que ele conhece bem por sua própria experiência de narrador, já não permite fazer da obra o balbucio da pitonisa. Acampa-se então em uma dicotomia entre tema (inspiração demoníaca) e escritura (racionalização humana) que parece voltarmos ao nível que em 1870 havia chegado [Gustavo Adolfo] Bécquer em sua meditação sobre a arte poética, o que de qualquer modo é um progresso nesse árduo caminho que leva de uma sociedade arcaica a uma estrutura moderna. ${ }^{13}$

O crítico uruguaio, em "Los poetas modernistas en el mercado económico" (1967), havia formulado algo semelhante ao analisar o contexto de produção de Rubén Darío e seus companheiros do modernismo hispano-americano. Neste texto, Rama sustenta que para a constituição efetiva de um sistema literário seria necessária uma conscientização do poeta em relação a sua nova tarefa. Ele deveria assumir a postura de um produtor cultural, diante da inexistência de um mercado consumidor para suas poesias, de um público leitor, e, consequentemente, da impossibilidade de sua profissionalização. $\mathrm{O}$ autor deveria tomar para si uma função necessária na nova sociedade burguesa - escritor de jornais - e ainda participar da formação de seus leitores. Para Rama, os poetas modernistas teriam sido os responsáveis pelo início da formação do sistema literário na América hispânica $^{14}$.

\footnotetext{
${ }^{12}$ Ibidem, p.9-10.

${ }_{14}^{13}$ RAMA, Ángel. "Demonio vade retro", p.11.

${ }^{14}$ Posteriormente, este texto foi incorporado como quarto capítulo do livro Rubén Darío y el modernismo (1970). As pontuações a respeito das condições de produção e da necessidade de formação de público também estão registradas no ensaio "Diez problemas para el novelista latinoamericano" (1964), no qual, ao tratar da questão do "romancista e seu público", Rama recorda o prólogo de Prosas profanas (1896), de Rubén Darío. Segundo o crítico uruguaio, somente na segunda metade do século XX o romance ganharia maior impulso, pela ampliação de seu público com os consumidores provenientes de uma classe média. Contudo, apesar do crescimento, esse número de leitores ainda seria reduzido e concentrado, situação que mudaria radicalmente nos anos sessenta.
} 
Em "Demonio vade retro", o crítico uruguaio estabeleceu um comparativo entre as ideias de Vargas Llosa e a do escritor argentino Ernesto Sabato, em El escritor y sus fantasmas (1963), atribuindo a ambas as concepções um caráter semântico impreciso, sendo a metáfora operada por Vargas Llosa um regresso à "teologia"15. A esta crítica respondeu o escritor peruano, em "El regreso de Satán", que os "demônios" de seu ensaio não são os "sulforosos personagens dos Evangelhos", mas criaturas estritamente humanas, sendo "certo tipo de obsessões negativas - de caráter individual, social e cultural", que indispõem o homem com a realidade em que vive, "chegando ao extremo da ambição de contradizer esta realidade refazendo-a verbalmente" ${ }^{\prime 16}$. Assim, Vargas Llosa declara:

Aceito que o emprego do termo "demônio" é impreciso; não usei "obsessão" porque poderia sugerir que adotava a explicação "psicologista" ortodoxa da vocação. Nem todas as obsessões são literariamente fecundas, só as de certo tipo muito particular, que tratei de descrever, num caso concreto, num grande capítulo do livro (o segundo da primeira parte). ${ }^{17}$

Trata-se precisamente do capítulo intitulado "El novelista y sus demônios", no qual o escritor peruano desenvolveu sua teoria, atribuindo substancialmente a vocação do romancista a dois aspectos específicos da criação literária, são eles: "dissidência" ou "rebeldia" e "obsessões" ou "demônios". O caso concreto, mencionado pelo escritor peruano, é o de García Márquez, cuja obra, a seu ver, pode ser lida a partir de uma "ambição única", de um projeto criador que encontra nas experiências de sua infância, família e na cidade de Aracataca, o núcleo decisivo de sua vocação ${ }^{18}$. Para Vargas Llosa, situar no domínio das "obsessões" o impulso da criação

[...] não é, de nenhum modo, desterrar fora do humano - colocando-a no céu, ou, melhor dito, no inferno - a origem da narrativa, senão, ao contrário, enraizá-la na realidade mais "social" e verificável. Os "demônios" a que me refiro são todos

${ }^{15}$ RAMA, Ángel. "Demonio vade retro", p.11.

${ }^{16}$ VARGAS LLOSA, Mario. [1972]. "O regresso de Satã". In: Contra vento e maré. Rio de Janeiro: Francisco Alves, 1985.p.179. Ao nos referirmos às declarações de Vargas Llosa optamos por utilizar a tradução para o português, publicada no livro Contra vento e maré (1985).

${ }^{17}$ Idem.

${ }^{18}$ Vargas Llosa relacionou personagens e temas das obras de García Márquez aos "demônios" pessoais, culturais e históricos - mesmo aqueles não vivenciados diretamente, como as guerras civis que precederam o apogeu econômico da região bananeira na Colômbia, e que terminaram com a guerra dos mil dias (1899-1902), a qual o escritor teve acesso a partir da narrativa de seus avós. (VARGAS LlOSA, Mario. Gabriel García Márquez: historia de un deicidio. Barcelona: Barral Editores, 1971, p.88-238). 
racionalmente caçáveis, porque procedem de friç̧ões e desencontros entre a história singular de um indivíduo e a história do mundo em que vive. ${ }^{19}$

Embora Rama tenha aproximado as ideias de Vargas Llosa e Ernesto Sabato, pelo viés das "imprecisões" semânticas, ao nos determos na análise de $E l$ escritor y sus fantasmas (1963) podemos observar outros percursos possíveis, o que corrobora no enunciado da existência de diferentes perspectivas no âmbito literário latino-americano dos anos sessenta e setenta, cuja interação realizava-se através de um campo em disputa. Sabato inclusive era uma figura controversa no meio literário, que embora elogiado por grandes críticos da literatura mundial como Graham Greene, Thomas Mann, José Saramago e Albert Camus, teve recepção irregular em seu país e na América Latina. O escritor argentino Ricardo Piglia afirmou mais de uma vez que as críticas a Sabato eram exacerbadas por fatores extraliterários. Em entrevista concedida em 2009 à revista eletrônica Letral, da Universidade de Granada, Piglia disse ver em Sabato parentescos com Juan Carlos Onetti, mas ressalvou que um crítico dificilmente reconheceria os laços, "porque Sabato ficou relegado, talvez por ser um tipo de escritor com posições políticas muito oportunistas, muito exibicionista, antipático e muito arrogante". Em seguida, esclareceu que, apesar das semelhanças, considerava Onetti bastante superior ${ }^{20}$.

Em El escritor y sus fantasmas, Sabato afirma que a característica essencial da literatura reside na complexidade da representação da experiência humana, sendo o romance, independentemente de seu lugar de enunciação, um instrumento epistemológico vital na crise do mundo moderno, uma vez que combina o pensamento lógico e o pensamento mítico, superando a capacidade dos sistemas racionalistas no conhecimento e interpretação da consciência humana. Dialogando com o pensamento sartreano ${ }^{21}$ e camusiano ${ }^{22}$ - tendo este último uma clara influência em El escritor y sus fantasmas -, Sabato procurou refletir sobre os aspectos que conformavam a função social da literatura, perguntando-se como,

${ }^{19}$ VARGAS LLOSA, Mario. [1972]. “O Regresso de Satã”, p.179-180.

${ }^{20}$ PIGLIA, Ricardo apud HOLLANDA, Diogo. "Ernesto Sabato entre a glória e o desprezo". Revista Garrafa, n. 24, maio-agosto de 2011, vol. II.

${ }^{21} \mathrm{O}$ discurso de Sabato - assim como o de outros escritores na década de sessenta - parte dos princípios de liberdade e responsabilidade enunciados na concepção de compromisso do escritorintelectual de Sartre. Sobre o compromisso do escritor em Sartre, consultar o capítulo II.

${ }^{22}$ A relação de Albert Camus e Ernesto Sabato se estende para além do plano das ideias, uma vez que o próprio Camus foi quem recomendou à editora Gallimard, em Paris, a publicação do primeiro romance de Sábato, El Túnel (1948). 
por que e para quê se escreve ficções. Inquietude compartilhada por distintos intelectuais numa época em que, para além dos princípios estéticos, estavam em pauta os propósitos políticos e ideológicos do texto. Na percepção de Sabato, "o escritor de ficções profundas é no fundo um antissocial, um rebelde, e por isso amiúde é companheiro de viagem dos movimentos revolucionários. Mas quando as revoluções triunfam, não é estranho que volte a ser um rebelde"23. Tanto Ernesto Sabato como Vargas Llosa, em investigações que partem de suas experiências como escritores, coincidem com a adoção da rebeldia como característica da literatura e da vocação do escritor.

É interessante observar que, na linha de aproximação das ideias de Vargas Llosa e Sabato, o pensamento camusiano é de fundamental importância. Para Albert Camus, o romance nasce ao mesmo tempo em que o espírito de revolta e traduz no plano estético a mesma ambição. Camus realiza uma distinção entre a literatura de consentimento, que coincidiria em geral com os séculos antigos e clássicos - onde o romance está praticamente ausente -, e a literatura de dissidência, que começa com os tempos modernos - onde o gênero tomará forma. Assim, Camus considera que a contradição humana está na base da revolta, pois o homem tem de aceitar e recusar o mundo real tal como este lhe é dado, contradição esta que se expressa na criação. Portanto, a seu ver, o artista vive uma constante ambiguidade, pois é incapaz de negar o mundo real e, ao mesmo tempo, dedica-se a contestá-lo no que ele tem de inacabado. Para o autor, esta contestação está longe da moral ou do puramente formal, essa correção visa primeiro à unidade e traduz uma necessidade metafísica ${ }^{24}$.

O próprio Vargas Llosa confessou em “Albert Camus y la moral de los limites" (1975) que, após um período de desencontros com as ideias de Camus, voltou a ler suas obras na década de setenta, principalmente L'homme revolté (1951), no qual encontrou afinidade intelectual com seu pensamento sobre política, história e cultura ${ }^{25}$. Para o escritor peruano, as questões mais valiosas das

${ }^{23}$ SABATO, Ernesto. El Escritor y sus fantasmas. $2^{\text {a }}$ Ed. Buenos Aires: Aguilar, 1964.p. 160.

${ }^{24}$ CAMUS, Albert. O homem revoltado. $9^{\text {a }}$ Ed. Rio de Janeiro - São Paulo: Editora Record, 2011, p.282-289.

${ }^{25}$ A publicação de L'homme revolté (1951) agitou a esquerda francesa, gerando uma série de polêmicas, dentre elas a que pôs em lados opostos Camus e Sartre. Em suma, em L'homme revolté, Camus teceu severas críticas em torno das revoluções planificadas pela ideologia, não poupando nem a tradição revolucionária francesa nem a russa. Para o autor, o espírito de revolta poderia levar um indivíduo ao fanatismo político, resultando em violência e terror, como aconteceu com o socialismo soviético, propondo como alternativa um estado de espírito rebelde. Por sua vez, Sartre 
ideias de Camus eram seus posicionamentos contrários ao totalitarismo, terrorismo, fanatismos e ditaduras, ou seja, o ensinamento sobre a "moral dos limites", que pressupunha o horror a todo tipo de dogma ${ }^{26}$. Este tipo de pensamento esteve presente, explicitamente, no romance La guerra del fin del mundo $(1981)^{27}$, assim como nas críticas de Vargas Llosa a todo e qualquer movimento que se dissesse revolucionário e que por ventura utilizasse meios violentos e restringisse o direito do homem à liberdade.

A atitude crítica de Vargas Llosa, seus discursos e romances podem ser compreendidos como um todo que se entrecruza, dimensionando o que o autor considera como o compromisso do escritor e o papel social da literatura. Para ele, o direito de discordar é inalienável a qualquer ser humano e a dissidência uma característica fundamental do romance moderno, convicção que esteve presente no discurso de Vargas Llosa desde o início de sua trajetória intelectual, como vimos no capítulo I.

Em Gabriel García Márquez: historia de un deicidio (1971), Vargas Llosa baseia sua argumentação na experiência pessoal de um autor para configurar aquilo que nomeia como "os demônios do escritor”. Este elemento é fundamental

também condenava os campos soviéticos, as perseguições e censuras, mas compreendia o ensaio de Camus como uma crítica unilateral que destruía a esperança no socialismo. Até a sua morte em 1980, Sartre acreditava que o socialismo era o único caminho para a eliminação das injustiças e da desigualdade social. Vargas Llosa tomou conhecimento dessa polêmica um ano depois, ao ler as crônicas da revista Sud, e na época posicionou-se favorável a Sartre. Entre 1962 e 1964, Vargas Llosa escreveu alguns artigos sobre os Carnets, obra póstuma de Camus, sem muito entusiasmo. Neste momento, influenciado pelas formulações de Sartre, acreditava que o argelino pecava por um excesso de lirismo intelectual, reprovando ainda a atitude de Camus em relação ao drama argelino. Com a fragmentação da esquerda latino-americana no final dos anos sessenta, o pensamento camusiano emergiu como um engajamento alternativo diante das novas configurações políticas e do aumento da censura em Cuba. Vargas Llosa, motivado tanto por sua decepção com Sartre e Cuba, como pelo atentado terrorista em Lima (1975), voltou a ler as obras de Camus, desta vez como um entusiasta de seus posicionamentos. (VARGAS LLOSA, Mario. [1975] “Albert Camus e a Moral dos Limites". In: Contra vento e maré. Rio de Janeiro: Francisco Alves, 1985.p.230-231).

${ }^{26}$ Idem.

${ }^{27}$ La Guerra del fin del Mundo foi o primeiro livro de Vargas Llosa cuja paisagem não retratava o Peru. Trata-se de um romance baseado na intertextualidade com Os Sertões, de Euclides da Cunha, retratando a Guerra de Canudos a partir de discursos polifônicos, com diálogos diretos entre a história e a ficção, que se refletiam nos tipos de procedimentos jornalísticos e documentais adotados pelo escritor peruano na pesquisa base para a criação da obra. Segundo o crítico literário norte-americano Seymour Menton, a condenação ao fanatismo é o eixo de toda a estrutura narrativa empreendida por Vargas Llosa no romance. Para o crítico, a posição política assumida por Vargas Llosa o levou a condenar o fanatismo sob a lógica da cegueira ideológica. Desse modo, no romance o escritor peruano teceu críticas não só à direita, como à esquerda e aos guerrilheiros peruanos do Sendero Luminoso. (MENTON, Seymour. "La Guerra contra el fanatismo de Mario Vargas Llosa". University of California, Irvine. AIH. Actas X, 1989. Centro Virtual Cervantes, p.811-817). 
na análise do escritor peruano, pois, a seu ver, encontra-se arraigado no exercício da vocação do romancista, chegando a transparecer na narrativa. Além disto, Vargas Llosa enuncia a personificação do autor em seus próprios romances, através da construção de enredos e personagens autobiográficos, como por exemplo em La ciudad y los perros (1963), La casa verde (1965) e La tía Julia y el escribidor $(1977)^{28}$. Nesta direção, é possível uma aproximação da interpretação do escritor peruano com a famosa formulação de Roland Barthes, sobre "a morte do autor" - que na época era uma das teses mais prestigiadas do horizonte interpretativo moderno -, ainda que seja para refutá-la.

Em A morte do autor (1968), o francês Roland Barthes problematiza a vinculação autor/obra em sua finalidade hermenêutica, questionando a validade de uma interpretação única da obra. A seu ver, o texto é um conjunto de citações, no qual o sujeito autoral desaparece. Ao escrever, o autor organiza através da forma uma trama de referências que existem independentes da existência de seu ser. Para Barthes, são as forças culturais da modernidade que fabricam a função autoral em termos de um aparato que atende as demandas do momento, de uma ideologia que oculta as condições de produção e naturaliza os significados. De acordo com Barthes, o ser total da escrita se revela na medida em que se considera que "um texto é feito de escritas múltiplas, saídas de várias culturas e que entram umas com as outras em diálogo, em paródia, em contestação" ${ }^{29}$. Neste ponto, é possível uma aproximação com o que Vargas Llosa chama de "demônios" culturais e/ou históricos. Para o escritor peruano, os "demônios culturais" são aqueles que incidem sobre as experiências que o escritor sentiu indiretamente, mediante a arte, a música, a mitologia, etc. Por sua vez, os "demônios históricos" são os acontecimentos de caráter social que o escritor compartilha com a sociedade. As aproximações entre Barthes e Vargas Llosa param por aqui, pois a ênfase empregada pelos dois intelectuais assume caráter distinto.

\footnotetext{
${ }^{28}$ Para Raymond Williams, nos romances de Vargas Llosa posteriores à década de setenta, com algumas exceções, como La fiesta del chivo (2000), seria mais apropriado falar da "intertextualidade". Embora, em certo sentido, possamos ver alguma similaridade deste conceito com a perspectiva dos "demônios culturais". (WILLIAMS, Raymond L. Vargas Llosa: outra historia de un deicidio. México: Taurus, 2001, p.286).

${ }_{29}$ BARTHES, Roland. "A morte do autor". In: BARTHES, Roland. O rumor da língua. São Paulo: Martins Fontes, 2004, p.64.
} 
Roland Barthes questiona a importância dada pela crítica literária moderna ao autor e seu contexto na interpretação da obra ${ }^{30}$. Neste sentido, propõe duas acepções como ponto de partida: a primeira revela a historicidade da própria noção de autor; na segunda trata-se da compreensão de que a escrita é a destruição de toda a voz, de toda a origem. De acordo com Barthes:

[...] desde o momento em que um fato é contado, para fins intransitivos, e não para agir diretamente sobre o real, quer dizer, finalmente fora de qualquer função que não seja o próprio exercício do símbolo, produz-se este desfasamento [...], o autor entra na sua própria morte, a escrita começa. ${ }^{31}$

Opondo a imagem do autor a do que nomeia como "scriptor moderno", Barthes justifica que este último já não tem em si paixões, humores, sentimentos, impressões, mas "esse imenso dicionário de onde retira uma escrita que não pode ter parada", sendo assim "[...] a vida nunca faz outra coisa senão imitar o livro, e esse mesmo livro não é mais que um tecido de signos, imitação perdida, infinitamente recuada" "32. Para ele, o "scriptor moderno" nasce ao mesmo tempo em que o seu texto, não sendo de modo algum sujeito, no qual seu livro seria o predicado. Deste modo, ele considera que há um lugar em que essa multiplicidade se reúne:

[...] esse lugar não é o autor, como se disse até o presente, é o leitor: o leitor é o espaço mesmo onde se inscrevem, sem que nenhuma se perca, todas as citações de que é feita uma escritura; a unidade do texto não está em sua origem, mas no seu destino, mas esse destino não pode mais ser pessoal: o leitor é um homem sem história, sem biografia, sem psicologia; ele é apenas esse alguém que mantém reunidos em um único campo todos os traços de que é constituído o escrito. [...] Sabemos que, para devolver à escritura o seu futuro, é preciso inverter o mito: o nascimento do leitor deve pagar-se com a morte do Autor. ${ }^{33}$

\footnotetext{
${ }^{30}$ Conforme assinala Marcio Renato Pinheiro da Silva, a concepção de texto de Barthes difere das do Formalismo Russo (o texto é um objeto imanente), do New Criticism anglo-americano (por ser um objeto, também, imanente, o texto possui elementos que lhe são intrínsecos e extrínsecos), do Estruturalismo (o texto é o resultado da combinação de estruturas organizadas por um centro que, apesar de empreender tal organização, está fora da articulação, não é afetado por elas, sendo, portanto, transcendente). Em vez disso, Barthes aborda o texto em sua produtividade, a qual não possui limites/limitações nem fronteiras, abrindo caminho para uma complexa configuração da significação, bem como a uma posição radical e iconoclasta do leitor. Barthes abre uma reflexão que, até então, excetuando os trabalhos de Jacques Derrida e de Julia Kristeva, não tinha precedentes; reflexão que, também, possui suas ambivalências. (PINHEIRO DA SILVA, Marcio. R. "As ambivalências textuais de Roland Barthes". Acta Scientiarum: human and social sciences, Maringá, v. 25, n. 1, p. 18).

${ }^{31}$ BARTHES, Roland. "A morte do autor", p.58.

${ }^{32}$ Ibidem, p.62.

${ }^{33}$ Idem
} 
Em sua proposição Barthes procurou relativizar o valor atribuído à figura do autor, potencializando a força da linguagem. Para ele, uma vez que o império do autor paralisa a atividade interpretativa, reduzindo-a a decodificação biográfica, sua morte significaria a libertação da pluralidade de sentidos do texto. Ao proclamar a "morte do autor", Barthes almejava a morte tanto do império do autor quanto da crítica e do conceito tradicional de obra, incorporando o leitor na percepção do texto em sua produtividade, ou seja, em sua polifonia. Trata-se, para Barthes, de assumir o jogo literário como uma atividade "contrateológica" e, propriamente, revolucionária, "pois a recusa de deter o sentido é finalmente recusar Deus e suas hipóstases, a razão, a ciência, a lei" ${ }^{34}$.

Pois bem, se a tese de Barthes repercutiu amplamente nos modelos interpretativos, Vargas Llosa se lança na contracorrente da época. No texto $A$ morte do autor (1968), Barthes propõe uma análise da intrínseca estrutura da narrativa e do código do romance, ou seja, uma análise por dentro da linguagem, cuja decorrência enfraquece os elementos exteriores ao texto, como a biografia do autor ou os fatos sociológicos ao redor. Para o escritor peruano, o método biográfico torna-se pertinente na medida em que através dele pode-se encontrar a raiz e as causas do desacordo do escritor com a "realidade real", por conseguinte, o verdadeiro significado da obra literária. A seu ver, trata-se de "um método de exploração do labirinto, em nenhum caso suficiente, que pode e deve ser completado por outros, capazes de abarcar os múltiplos planos do universo ficcional: o linguístico, o estrutural, o histórico, o ideológico"35. Na percepção de Vargas Llosa, se o propósito do crítico é concentrar-se no exame de algum destes planos, ele pode, sem danos, abandonar todo o material biográfico. Porém, se a intenção é mostrar o mecanismo através do qual uma obra de ficção nasce ou o processo que culmina no exercício da vocação de um romancista, o método biográfico é completamente pertinente, ainda que muitos o considerem "fora de moda"36. Neste sentido, o pensamento de Barthes seria, a seu ver, demasiadamente esquemático, pois sua "interpretação se baseia puramente na explicação formal da obra literária”. Para ele, este é um tipo de análise

\footnotetext{
${ }^{34}$ Ibidem, p.63.

${ }^{35}$ VARGAS LLOSA, Mario. [1972]. "Ressureição de Belzebu, ou a Dissidência Criadora". In: Contra vento e maré. Rio de Janeiro: Francisco Alves, 1985, p.195.

${ }^{36}$ Idem.
} 
insuficiente como explicação da vocação do romancista e da natureza da literatura ${ }^{37}$.

A exposição feita aqui sobre o pensamento de Barthes, em relação ao autor e ao método biográfico na crítica literária, torna-se ainda mais pertinente na medida em que o crítico uruguaio Ángel Rama utiliza-o como uma das referências para criticar a ênfase de Vargas Llosa no método biográfico em seu estudo sobre García Márquez. Em sua resposta ao escritor peruano, intitulada El fin de los demonios, Rama reprova, além do método, a forma assumida pelo ensaio que, a seu ver, comunga com as características metodológicas e o endurecimento das universidades espanholas. De acordo com Rama, se trata "de uma estrutura rígida", "filha do historicismo e do biografismo romântico" de Augustin Thierry e Charles Augustin Sainte-Beuve, um biografismo que não serve como instrumento capaz de penetrar, em forma universal e abstrata, "se tal coisa fora possível", na gênese da criação literária ${ }^{38}$. Assim, o crítico uruguaio considera que:

Se tal "forma" é previsível em um jovem candidato ao doutorado, é insólita em um escritor distinguido por seu experimentalismo das formas narrativas, o que apontaria que a contaminação arcaica da tese se estende às formas ensaísticas, ou que estas nos introduzem em uma contradição que vem advertindo-se na produção de Mario Vargas Llosa e opõe romances ou alguns lúcidos ensaios sobre problemas atuais com as teses que tem proposto (sobre a decadência da narrativa do Ocidente a respeito da latino-americana, sobre a infelicidade do escritor como fonte da obra literária, sobre a suposição criativa dos períodos de iminência revolucionária) que estão distante de terem sido provadas. Na mesma tendência, seu livro não é apresentado como uma "monografia", senão como um "ensaio" que intenta a "descrição do processo da criação narrativa a partir de um autor concreto". Desdenha do título que cabe a noventa por cento do material (Gabriel García Márquez, vida e obra) para assumir o mais retumbante de Gabriel García Márquez: historia de un deicidio. ${ }^{39}$

Ángel Rama especifica que sua objeção não se dirige ao livro como um todo, mas sim à tese que ele comporta. Para o crítico uruguaio, repor este tipo de argumentação seria prejudicar os esforços da cultura latino-americana até os níveis mais racionais compatíveis com os projetos de transformação de sua sociedade. Portanto, seria esta uma tese ineficaz para atender as exigências do sistema literário e cultural latino-americano, tanto em seu autoconhecimento como

\footnotetext{
${ }^{37}$ CANO GAVIRIA, Ricardo. El Buitre y el Ave Fénix: Conversaciones con Mario Vargas Llosa. Barcelona: Editorial Anagrama, 1972, p.19-20.

${ }_{38}^{38}$ RAMA, Ángel. "El fin de los demonios", p.23-24.

${ }^{39}$ Ibidem, p.24 [tradução nossa].
} 
em sua contribuição para a transformação sócio-política ${ }^{40}$. Rama considerava que diversas metodologias desprezadas por Vargas Llosa, como a reconstrução da retórica operada pelo estruturalismo, a psicanálise pós-junguiana, o neomarxismo ocidental $^{41}$, a linguística transformacional, etc., contribuíam para uma leitura coerente de toda a literatura passada, pois "como diria Barthes, a introduziria no sistema de nossa linguagem"

Vargas Llosa defendeu-se das críticas de Rama sustentando que suas opiniões lançam mão de imagens românticas, mas que seu conteúdo deve-se mais a Freud ou a Sartre. O escritor peruano citou como aproximação metodológica o estudo de Sartre sobre Flaubert, em L'Idiot de la Famille (1971). Embora, na época, não o tivesse lido completamente, considerava que neste estudo a sociologia, a história, a psicanálise, a linguística, a antropologia e outras disciplinas convergiam para mostrar "o que se pode saber hoje de um homem",43. E assim complementa Vargas Llosa:

\begin{abstract}
A 'pura' interpretação psicanalítica da vocação literária, como sistemática transferência compensatória de certos traumas neuróticos, parece-me excessivamente psíquica e insuficientemente histórica e não a aceito sem reservas. Não há dúvida de que ela pode ser discutida (eu preferiria 'complementada') sob muitos ângulos. Mas pode-se acusá-la, com um mínimo de rigor, de "irracional" e "idealista"? [...]. Quando Rama aplica estes rótulos numa explicação do romancista [...] incorre na mesma "imprecisão semântica" que censura na minha 'teoria' e também na impropriedade de quem, à força de tanto lançar anátemas em vez de explicações, acabou por convencer os vocábulos 'idealismo' e 'irracionalismo' em ruídos intimidatórios sem qualquer significação conceitual. ${ }^{44}$
\end{abstract}

O escritor peruano formulou todo um modelo crítico, cujos pressupostos irão de encontro às principais tendências e ao vocabulário teórico-crítico da época, como por exemplo o estruturalismo, o formalismo russo, a semiologia e etc. Para Ángel Rama, isso revelava um "arcaísmo" teórico. A esta crítica respondeu Vargas Llosa:

[...] Se o ponto de referência é a vanguarda intelectual de esquerda na Europa, não há dúvida que minhas ideias são obsoletas: aquela analisa agora a literatura

\footnotetext{
${ }^{40}$ Ibidem, p 24-25.

${ }^{41} \mathrm{O}$ neomarxismo ou marxismo ocidental é compreendido como o conjunto das correntes nascidas nos anos vinte do século XX, em torno das teses de Georg Lukács, Ernst Bloch, Karl Korsch e Antonio Gramsci.

${ }^{42}$ RAMA, Ángel. "El fin de los demonios", p.27-28.

${ }^{43}$ VARGAS LLOSA, Mario. "O Regresso de Satã", p.180.

${ }^{44}$ Ibidem, p.180-181.
} 
através de um prisma construído com altas matemáticas, o formalismo russo dos anos vinte, as teorias linguísticas do círculo de Praga, o livro roxo de Mao e uma beliscada de orientalismo budista. Isso significa, também, que se a maneira de ser maduro e moderno na literatura é adotando, com algumas simplificações, as teses dos pensadores neomarxistas que a Europa Ocidental põe na moda, Rama está tão decrépito como suas convicções neo-lukacsianas e seu entusiasmo por Benjamin, como eu com meu romantismo satânico. ${ }^{45}$

As análises e conceitos formulados por Walter Benjamin permeiam muitos dos apontamentos realizados por Ángel Rama na polêmica com Vargas Llosa. O principal destes é o conceito do autor como produtor, que atravessa os três textos redigidos por Rama durante o debate. No ensaio $O$ autor como produtor (1934), Benjamin discute o papel dos escritores no combate ao fascismo, chamando a atenção para a necessidade do engajamento dos intelectuais no sentido de modificarem os meios de produção. É interessante observar que o texto de Walter Benjamin foi redigido no contexto de cisão da esquerda política alemã, que teve reflexos também no âmbito cultural ${ }^{46}$. Se nos atentarmos ao contexto da polêmica entre Ángel Rama e Vargas Llosa, poder-se-ia dizer que se trata também de um momento de cisão da esquerda intelectual latino-americana, com a fragmentação dos intelectuais em torno do governo revolucionário cubano e as divergências pós "caso Padilla", como vimos no capítulo III. Neste sentido, não é estranho que Rama evoque, durante o debate com Vargas Llosa, o conceito do escritor como produtor, fruto de uma interlocução com a argumentação produzida por Walter Benjamin.

Na leitura de Rama, elementos como o desenvolvimento das sociedades latino-americanas, a complexidade crescente das bases econômicas, a aparição de novos grupos sociais e suas demandas, elevaram uma "moderna" acepção do escritor assimilado a um produtor. Nesta dimensão, o artista é visto como ser social, determinado pelas circunstâncias históricas em constante processo de transformação. Por isso, para Rama, ao invés de um escritor vitimado pela

\footnotetext{
${ }^{45}$ Ibidem, p. 185 .

${ }^{46}$ No ensaio $O$ autor como produtor, Walter Benjamin construiu sua argumentação a partir de uma visão crítica da "esquerda" alemã. Do texto de Benjamin emerge justamente uma situação que se desenvolvera desde o final da Primeira Guerra Mundial, ou seja, a cisão definitiva na esquerda política alemã entre o tradicional SPD - Partido Social-Democrata da Alemanha e o KPD Partido Comunista da Alemanha, fundado em 31 de dezembro de 1918. O cenário cultural alemão durante a República de Weimar não ficou alheio a essa cisão e, por assim dizer, estabeleceu determinadas "frentes" no exílio, durante o regime nazista, que perdurariam ainda no pós-guerra. (BENJAMIN, Walter, "O autor como produtor". In: LISBOA, ASSÍRIO \& ALVIM, A modernidade. (Obras escolhidas de Walter Benjamin), 2006, pp. 271-293). (Conferência pronunciada no Instituto para o Estudo do Fascismo em Paris, em 27 de abril de 1934).
} 
sociedade, que vê a si mesmo como o "forçoso intermediário entre um universo de forças obscuras e um público homogêneo" que necessitaria dessas pulsações misteriosas, objetivadas numa individualidade excepcional, "que proporciona a obra literária encarada como afirmação do autor e dissidência com a estrutura da realidade", o momento solicitaria a ratificação do escritor-produtor "como o correto representante de nosso tempo" ${ }^{\text {47 }}$. Na definição de Rama:

Ele [o escritor-produtor] elabora conscientemente um objeto intelectual - a obra literária - respondendo a uma demanda da sociedade ou de qualquer setor que está necessitado não somente de dissidências senão de interpretações da realidade que pelo uso de imagens persuasivas permita compreendê-la e situar-se em seu seio validamente. A obra não é então espelho do autor nem de seus demônios, senão mediação entre um escritor mancomunado com seu público e uma realidade desentranhada livremente, a que somente pode alcançar coerência e significado através de uma organização verbal. ${ }^{48}$

Para o crítico uruguaio, Vargas Llosa se "esquece" que o escritor não é um indivíduo fechado em si mesmo, que se opõe à "totalidade que é o mundo", senão que integra um grupo social, uma classe, um movimento, e nem sequer é o único homem "golpeado pelas asperezas do mundo, nem golpeado de forma tão única que não encontre seres semelhantemente afetados"49. Ángel Rama, pensando na literatura como uma das manifestações da cultura, isto é, como uma produção simbólica permeada pelas lógicas do social, do político, do tecnológico e do econômico, argumenta que o escritor, como membro de uma comunidade, resulta moldado pelas condições culturais de seu país, período, setor social, participando deste plano nacional, histórico, grupal ou classista na evolução de sua sociedade e, portanto, expressa valores que não são restritamente individualistas, senão próprios de coordenadas que somente se podem definir como "sociais"

É interessante ressaltar que Rama já havia pontuado esta questão em outro texto no qual analisa a produção do romance. Em "Diez problemas para el novelista latinoamericano" (1964), o crítico uruguaio, na segunda problemática examinada, a saber, "as elites culturais", explica que, por mais que o escritor privilegie o individualismo, funcionará sempre dentro de um determinado grupo social. Esse grupo, a seu ver, marcaria a incorporação social do criador e

\footnotetext{
${ }^{47}$ RAMA, Ángel. "Demonio vade retro", p.09-11.

${ }^{48}$ Ibidem, p.10-11(grifos nossos).

${ }^{49}$ Ibidem, p. 29.

${ }^{50}$ Ibidem, p.29-30.
} 
estabeleceria certa densidade ao grupo de letrados ${ }^{51}$. Na quarta problemática levantada por Rama, "o romancista e a literatura nacional”, o crítico argumenta que um autor nasce, forma-se, desenvolve-se dentro de uma literatura e até mesmo contra ela. Nos países dotados de literatura nacional, o autor seria, ao mesmo tempo, herdeiro e criador de tradições. Embora ele ressalte que na América Latina, apesar de em muitos casos haver uma literatura nacional, dificilmente se verificaria o registro de autonomia por parte dessas literaturas ${ }^{52}$.

Em certo sentido relacionado à questão acima, estaria o sexto ponto, denominado pelo crítico uruguaio "los maestros literarios". Rama sustenta que um escritor estaria condicionado a determinado âmbito sociocultural, sendo formado, também, pela literatura anterior à dele. A seu ver, ao realizar sua criação literária, o romancista deveria voltar-se para as características próprias de sua região cultural, e não buscar uma correlação com movimentos ou valores externos. Para ele, as técnicas, veículos de expressão entre os âmbitos externo e interno, deveriam ser adaptadas, numa espécie de "nacionalização" das técnicas que fazem parte do sistema-mundo. De acordo com Roseli B. Cunha, esta formulação poderia ser entendida como o próprio processo de transculturação e ocorreria, também, em três níveis: o da língua, o da estruturação narrativa e o da cosmovisão, apresentados por Rama em Transculturación narrativa en América latina $(1982)^{53}$.

Em “Diez problemas para el novelista latinoamericano" (1964), no que se refere à estrutura narrativa, Rama sustenta que o autor, principalmente o romancista, anseia por não se restringir à vida interior, tentando encontrar o modo pelo qual suas tendências se animariam e se consolidariam em formas objetivas. Não se trata do "objetivismo francês do nouveau roman", mas da busca de uma objetividade como descoberta de um universo que pode ser compartilhado. Desta forma, segundo o crítico uruguaio, a objetivação dar-se-ia, por parte do

51 RAMA, Ángel. "Diez problemas para el novelista latinoamericano". In: Crítica literaria y utopía en América Latina. Medelín: Editorial Universidad de Antioquia, 2005, p.12-16.

52 Ibidem, p.21-29.

53 De acordo com a autora, posteriormente, os três níveis - língua, estruturação narrativa e cosmovisão - seriam considerados níveis da transculturação. Em "Diez problemas para el novelista latino-americano" (1964) estes níveis são tematizados como "El novelista y la lengua", "La novela, género objetivo" e "Las filosofias en la novela", respectivamente os quinto, sétimo e oitavo tópicos apontados como problemas para o romancista. (CUNHA, Roseli Barros. Transculturação narrativa: seu percurso na obra crítica de Ángel Rama. São Paulo: Humanitas Editorial, 2007, p. 302). 
romancista, na escolha de seu tema. Um ajuste entre a vivência pessoal do autor e uma estrutura passível de ser compartilhada pelos outros homens. Para ele, o romancista deveria procurar tal objetivação no funcionamento dos personagens, pois as situações vivenciadas por estes (mesmo as de caráter privado) estariam implicadas no processo integral da sociedade e responderiam a elas não como elementos determinados ou como consequências esquemáticas, mas como um diálogo vivo que todo homem estabelece com o seu tempo. Em todo caso, a função do romance não seria a de substituir os tratados de sociologia, e sim promover estruturas de sentido que situassem artisticamente o homem no mundo. Um exemplo bem sucedido desta objetivação seria, de acordo com Rama, o romance Cien años de soledad (1967), de García Márquez ${ }^{54}$. No artigo de 1964, Rama sublinhará o "dom criador" dos romancistas, especificando que, em todo caso, não se deveria buscar no "ser escritor" uma exaltação romântica do mistério da criação, e sim o que ele considera como "vocação de ofício", que deveria ser cumprida como um modo de inserção, e até autojustificação, na sociedade ${ }^{55}$.

O crítico uruguaio parece aproveitar o ensejo do debate com Vargas Llosa para afirmar a institucionalidade da crítica literária, distinguindo os fazeres, repertórios e intencionalidades, tal como fizera em outro debate ocorrido também em 1972, durante o Coloquio del libro, realizado em Caracas, no qual apontou o que nomeou como "alguns fracassos da crítica". Para o crítico uruguaio, se fazia necessário um debate metodológico "entre os grandes críticos da América Latina", a fim de superar o que concebia como o campo empírico e pragmático no qual se encontrava a crítica latino-americana ${ }^{56}$. Para Rama, a crítica literária estava

${ }^{54}$ RAMA, Ángel. "Diez problemas para el novelista latinoamericano”, p. 51-56.

${ }^{55}$ Ibidem, p.73.

${ }^{56}$ A revista Zona Franca compilou boa parte do debate realizado no Coloquio del libro, trazendo no número de agosto $\left(n^{\circ} 14\right)$ uma ampla discussão sobre o boom, onde opinavam: Rama, Vargas Llosa, Rodríguez Monegal (os três principais protagonistas do debate), Juan Liscano, Rubén Barreiro Saguier, Benito Milla, Carlos Barral, Humberto Díaz Casanueva e Carlos Báez. Essa polifonia se reduziu no número de dezembro $\left(\mathrm{n}^{\circ} 16\right)$ quando somente Rama e Rodríguez Monegal escreveram sobre a matéria. De um lado estavam as percepções de Vargas Llosa e Rodríguez Monegal, que sustentavam uma autonomia do fazer literário diante das pressões mercadológicas, insistindo na eleição livre do público e da crítica, assim como nas conotações positivas em torno da experimentação linguística e estética das produções do boom. De outro, a percepção de Rama que num empenho sociológico propunha uma interpretação dos interesses do capital, fortemente assimilado à onomatopeia boom. Para Rama, "mais que um conjunto de escritores que alcançam com suas obras a expansão do mercado leitor, poderia falar-se de uma expansão do mercado que através de certos mecanismos "elege" determinados autores e obras". A crítica de Rama está direcionada, especificamente, ao poder de seleção do mercado sobre a produção literária existente. Embora, a seu ver, alguns agentes do campo literário correspondiam aos interesses do mercado para obter favorecimentos. (VANDEN BERGHE, Kristine. "Hacia una cartografia del Boom. Una 
substituindo os juízos e as análises pela informação; substituindo a interpretação pela mera descrição; e os jornalistas substituindo os críticos, veiculando informações sobre a vida do escritor, transformado em popstar para o grande público $^{57}$.

Na compreensão de Rama, por se tratar de um produto social comprometido com as demandas de uma sociedade determinada, a literatura e a sociedade formam um composto dentro do processo social, intimamente imbricado com o fazer político. Desta forma, se interpõem quatro elementos correlacionados: a literatura, a sociedade, a dimensão cultural e a dimensão ideológica. De acordo com o crítico uruguaio, este tipo de compreensão não pode ser diferente do que se espera do crítico literário: comprometer-se não só com as demandas sociais, mas com o (re)conhecimento do público a respeito dos escritores da comunidade latino-americana. Em sua análise no livro Rubén Darío y el modernismo (1970), Rama formaliza sua concepção de literatura:

Uma literatura é entendida, aqui, não como uma série de obras de valor, senão como um sistema coerente com seu repertório de temas, formas, meios expressivos, vocabulários, inflexões linguísticas, com existência real de um público consumidor vinculado aos criadores, com um conjunto de escritores que atendem as necessidades desse público e que, portanto manejam os grandes problemas literários e socioculturais. ${ }^{58}$

Neste trecho fica evidente a relação entre o pensamento de Rama sobre a literatura e o conceito de "sistema literário" de Antonio Candido, que compreende a literatura como uma conjugação entre autor, público e obra. Em entrevista concedida a Ángel Rama, em 1960, para o semanário Marcha, Antonio Candido sintetizou o que entendia por sistema literário:

a articulação dinâmica de um conjunto de autores e de um público consumidor real que atuam dentro do funcionamento eficaz da vida nacional, com um repertório de temas e de abordagens que asseguram a continuidade regular, em uma palavra, a tradição verdadeira de uma literatura. ${ }^{59}$

polémica en Zona Franca" (ag.-dic.1972). In: Les discours culturel dans les revues latinoaméricaines de 1970 à 1990. América, Cahiers du Criccal, n. 15, Paris, 1996, p.26). Disponível em: <http://www.persee.fr/doc/ameri_0982-9237_1996_num_15_1_1171〉.

${ }^{57}$ Ibidem, p.10-15.

${ }^{58}$ RAMA, Ángel. Rubén Darío y el modernismo: Circustancia socioeconómica de un arte americano. Caracas: Universidade Central de Venezuela, 1970, p. 11.

${ }^{59}$ RAMA, Ángel. "La nueva crítica brasileña: Antonio Candido". Marcha, Montevidéu, n.998, p.23, fev.1960. De acordo com Roseli Barros Cunha, pode-se pensar que "tradição verdadeira", segundo Candido, é a que se pauta pela busca da função total nas obras, ou seja, a correlação entre 
Rama cita os estudos que empreendeu na escrita do livro sobre Rubén Darío para repreender Vargas Llosa por extrair sua posição "da linha mais retraída do romantismo" e por desconsiderar análises que, a seu ver, concorriam a um progressivo entendimento social da cultura. De acordo com Rama:

\begin{abstract}
As explicações que o "excelente" Walter Benjamin (herdeiro das ideias estéticas "velhas" de Marx) fez da arte e dos artistas do XIX - que sem nenhum rubor reconheço que usei, junto com as de Fischer e outros marxistas ocidentais para escrever meu livro sobre Rubén Darío -, partindo do reconhecimento de que as ideias traduzem situações reais vividas por seus autores uma vez que é a existência que determina a consciência, não estão longe das interpretações que a partir de Max Weber fez a sociologia do conhecimento alemão que não pode ser equiparada simplesmente ao marxismo. [...] Todos esses materiais concorrem a um progressivo entendimento social da cultura que obviamente não é capricho nem ex-abrupto político, senão mera consequência do desenvolvimento universal das sociedades civilizadas, visível para qualquer análise científica. Em um lúcido texto Karl Mannhein revisava a história humana como sucessão de definições em que o homem se determinava frente a valores por ele ascendidos à categoria de absolutos: por muito tempo Deus, por um longo período romântico a história, pelo tempo presente a sociedade. E, este último ditava o esmagador crescimento da estrutura social contemporânea. ${ }^{60}$
\end{abstract}

Nesta passagem, o crítico uruguaio responde diretamente a consideração feita por Vargas Llosa a respeito do que ele chama de estética marxista. Nas palavras do escritor peruano: "Se é verdade que no meu livro existem poucas dúvidas com relação 'às ideias de Karl Marx' (que eram demasiadamente conservadoras), há, por outro lado, uma clara filiação entre esta maneira de estabelecer a relação matéria-forma e a dialética [...]”61. Esta relação matériaforma é, para Vargas Llosa, um complexo processo da criação narrativa no qual a dimensão irracional e inconsciente do criador aporta, principalmente, nos "temas" (as experiências negativas que são a origem da vocação rebelde que aspira reedificar a realidade) e a dimensão racional e consciente aporta, principalmente, nas "formas" (a técnica e o estilo) em que aqueles se cristalizam. O escritor peruano ressalva que esta divisão somente é possível como uma abstração teórica, uma vez que, na práxis, há uma interação dinâmica entre ambos os componentes da narração: “um 'tema' forma-se e transforma-se segundo vão sendo decididas,

a função ideológica, a social e "as mediações simbólicas que o poeta [autor] encontrou para dar relativa intemporalidade e alcance universal a matéria narrada". (CUNHA, Roseli Barros. Op. cit., p.40).

${ }^{60}$ RAMA, Ángel. "Demonio vade retro", p.29-30.

${ }^{61}$ VARGAS LLOSA, Mario. "O Regresso de Satã", p.183. 
escolhidas, as palavras e a ordem que o plasmam"62. Para Vargas Llosa, a visão de Rama é demasiadamente sociológica, o que implica uma leitura parcial do fato literário $^{63}$. E, complementa sua percepção afirmando que os termos "deicida" e “produtor” não são termos contraditórios, senão complementares:

\begin{abstract}
O primeiro alude à ambição rebelde que preside toda vocação narrativa, a aspiração do narrador de "refazer a realidade", e o segundo à condição do trabalhador cujas obras se convertem em "bens" (ou mercadorias) dentro de uma sociedade determinada. Onde está o antagonismo? Uma definição se refere ao problema individual da literatura e outra ao problema social: ambos existem, se condicionam e modificam mutuamente e eu nunca pretendi segregá-los, como faz Rama, ao reduzir a literatura, segundo o padrão positivista, à sua exclusiva função social. $\mathrm{Na}$ realidade, a diferença entre "deicida" e "produtor" é uma diferença de metáforas: a primeira presta seu termo ao vocabulário "religioso" e a segunda ao da "economia" e o divertido é que tanto Rama como eu somos profanos nessas matérias das que saqueamos imagens para explicar a literatura. ${ }^{64}$
\end{abstract}

Para Vargas Llosa, ao afirmar que o irracional é decisivo na "temática" de um escritor, isto não isenta sua responsabilidade com relação ao que escreve. A seu ver, está claro que um escritor não escolhe seus "demônios", mas sim o que faz com eles. "Não decide no que se refere às origens e fontes de sua vocação, mas sim os resultados" ${ }^{\prime 65}$. Neste âmbito, Ángel Rama percebe uma dicotomia entre tema (inspiração demoníaca) e escritura (racionalização humana) ${ }^{66}$. Para ele, este tipo de percepção corrobora com a "cegueira do escritor" em relação ao mundo real, e assinala que "quando disse [Vargas Llosa] que o escritor constrói sua obra para liberar-se de seus demônios, afirmo que se trata de servir a um determinado projeto cultural" $" 67$. E, neste projeto, interessa a Rama analisar a América Latina enquanto uma construção histórica de sua cultura, exigindo do crítico a capacidade de decifrar suas tramas simbólicas. Trata-se de um tipo de mediação da obra literária a que Rama dedicou longos anos de investigação, antecipando no debate com Vargas Llosa, ainda que de forma fragmentada, o que será aprofundado em obras como Transculturación narrativa en América Latina (1982) e La ciudad letrada (1984).

\footnotetext{
${ }^{62}$ Idem.

${ }^{63}$ Idem.

${ }^{64}$ Ibidem, p. 181.

${ }^{65}$ Ibidem, p.184.

${ }^{66}$ RAMA, Ángel. "Demonio vade retro", p.11.

${ }^{67}$ RAMA, Ángel. "El fin de los demônios", p.36.
} 
De todo modo, se as ideias traduzem situações reais vividas por seus autores, uma vez que é a existência que determina a consciência, o debate entre Vargas Llosa e Rama concorre a um progressivo entendimento das questões socioculturais que se interpunham na prática da crítica literária da época. E, ainda, que são os lugares de fala e os projetos intelectuais assumidos pelos interlocutores do debate que são ressaltados na medida em que os repertórios são requeridos durante o confronto. Desta forma, Rama enquanto crítico literário ressaltava uma compreensão da América Latina implicada em seus elementos históricos, sociais e culturais, como um projeto que espera sua realização concreta, horizonte clarificado em sua declaração a respeito da modernização do sistema cultural latino-americano:

Creio que em nossa América foi [José] Martí o primeiro que percebeu esta nova condição da criação artística (ou, ao menos assim o expus em meu ensaio "La dialéctica de la modernidade em Martí") quando em 1881, exclamava: "Ao povo indeterminado, literatura indeterminada! Mas apenas se aproxima os elementos da união, aproximam-se e se sintetizam em uma grande obra profética os elementos de sua Literatura." Tal pensamento, que atravessa a melhor ensaística latino-americana do século, e que tão claro aparece em Mariátegui, permitiu que recentemente o antropólogo brasileiro Darcy Ribeiro situasse a perspectiva da cultura iminente em termos que estão nas antípodas da concepção que maneja Vargas [Llosa]. Dizia Ribeiro: "De fato, uma nova civilização está nascendo. Uma civilização que a respeito da cultura somente sabemos que será mais uniforme em todo o mundo e se baseará cada vez mais no saber explícito e na racionalidade". ${ }^{68}$

Pode-se considerar que ao ressaltar um futuro a ser construído, Rama está enfatizando a ideia de que a América Latina integrada seria um projeto cultural futuro a ser desenvolvido num viés intelectual e cultural. Nessa época, a cultura letrada e o intelectual eram considerados peças-chaves na construção de uma América Latina modernizada e integrada - ao menos no plano literário. No artigo "Esto es América" (1962), o crítico uruguaio declara: "América é nossa preocupação primeira" ${ }^{69}$. O projeto de integração da América Latina de Rama

${ }_{68}^{68}$ RAMA, Ángel. "El fin de los demonios", p.30-31.

${ }^{69}$ Neste texto, Rama destaca sua preocupação com a América no âmbito da cultura, principalmente na literatura. O crítico uruguaio privilegiará intelectuais que, segundo ele, estariam ansiosos pelo futuro da América e procuravam pensá-la de modo integrado, ao menos na literatura, mencionando autores como Juan Carlos Onetti, do Uruguai; Augusto Roa Bastos, do Paraguai; Jorge Icaza, do Equador; João Guimarães Rosa e Érico Veríssimo, do Brasil; José María Arguedas, do Peru; Juan Gelman, da Argentina. Todos esses autores, apesar dos estilos diversos, expressariam, na concepção de Rama, uma autêntica cultura de seu meio social. (RAMA, Ángel apud CUNHA, Roseli Barros, op. cit., p.281). 
propunha uma percepção do subcontinente acima das arbitrárias imposições administrativas coloniais. Para o crítico uruguaio era preciso buscar os traços que unificavam a América Latina, sem que isso deixasse de lado as diversidades regionais ${ }^{70}$.

De acordo com Cunha, evidencia-se, desde o início da atividade crítica de Rama, a ênfase numa necessidade de se constituir um sistema literário voltado para as peculiaridades do subcontinente. Anos depois, Rama aprofundará sua ideia, argumentando que a literatura deveria ser produzida a partir de uma conjunção entre o material interno de cada região da América Latina e as inovações técnicas que iam sendo incorporadas ${ }^{71}$. Para a autora, ao longo dos anos sessenta - de forma mais amadurecida em artigos como "Los construcción de uma literatura" e "Diez problemas para el novelista latinoamericano" - pode-se encontrar várias questões, temas e procedimentos que se estenderiam ao longo da carreira do crítico e alguns sinais de seus conceitos de transculturação narrativa e comarca cultural. Muitas destas questões teriam sido uma herança dos ensaístas do século XIX - tais quais Bolívar e Martí -, mas que também estariam presentes na geração anterior à sua, de Henríquez Ureña e Picón Salas, e também seriam fruto da percepção de uma tendência de sua época. Tal capacidade de estar "em situação", como diria Sartre, também seria uma constante na trajetória de Rama. Notar-se-ia uma ênfase no compromisso do intelectual com os problemas de seu tempo $^{72}$. Na década de setenta, Ángel Rama se aprofundaria na questão da pluralidade na América Latina, que já percebia no decênio anterior. Paralelamente a outros ensaios, o crítico vinha escrevendo os que posteriormente fariam parte de Transculturación narrativa en América Latina, publicado em 1982. Neste ensaio, a transculturação é entendida como um modo de inserção da obra literária tanto no mercado nacional quanto no internacional.

\footnotetext{
${ }^{70}$ Conforme Cunha, a ênfase que Ángel Rama e sua geração deram à ideia de que a América Latina seria um projeto cultural a ser construído intelectualmente está relacionada à "utopia harmoniosa" almejada por Henríquez Ureña. Para o crítico dominicano, a América seria uma "totalidade ideal", a ser alcançada pela consideração da diversidade cultural das regiões do subcontinente. Seria, portanto, um ideal, algo a ser constituído no futuro. Nessa concepção conciliatória, pode-se perceber um germe de dois conceitos desenvolvidos anos depois por Rama, um estabelecido por meio das particularidades regionais, como se sabe, comarca cultural; e outro, de uma operação de síntese cultural, que corresponderia ao processo de transculturação. (CUNHA, Roseli Barros, op. cit., p.30).

${ }^{71}$ Ibidem, p.307.

${ }^{72}$ Ibidem, p.306.
} 
Em contrapartida, o escritor peruano Vargas Llosa interessava-se na afirmação de um espaço específico do romance. Em suas argumentações, emergem conotações que, ao mesmo tempo, adquirem um sentido de afirmação, fatalidade e denúncia. Por um lado, o escritor peruano enfatizava uma nova condição da criação literária, em termos de especialização e de possibilidade de o escritor dedicar-se exclusivamente ao seu ofício, com a ampliação do mercado editorial $^{73}$. Por outro, é a condição de marginalidade do escritor, assinalada em diferentes ocasiões, que ocupou grande parte de sua crítica, como por exemplo no ensaio "Sebastián Salazar Bondy y la vocación del escritor en el Peru" (1966). Trata-se, em alguns aspectos, de uma denúncia quanto à desigualdade social e às condições de circulação da obra literária em sociedades que, em grande medida, eram assoladas pelo analfabetismo, denotando, ainda, a angústia do escritor diante do descaso das elites pela cultura e pelas políticas de promoção cultural.

O tema da "marginalidade" do escritor esteve presente no ensaio Gabriel García Márquez: historia de un deicido (1971), ocupando uma das seções do primeiro capítulo, embora esta problemática esteja diluída em todo o livro. Para Vargas Llosa, ao assumir a vocação literária, o escritor assume a práxis de um ser marginal. O autor considera que esta condição de marginalidade, origem e ao mesmo tempo resultado da vocação literária, se projeta de formas variadas, complexas, "às vezes elusivas e quase indetectáveis, às vezes óbvias, nos produtos desta práxis" ${ }^{74}$. Segundo o escritor peruano:

O tema da "marginalidade" atravessa toda a literatura narrativa [...]. Sua manifestação mais corrente é, desde logo, a anedota: não é fortuito que o tema do "excluído", do "pária", do "diferente", reapareça maniacamente nas fícções, desde os super-homens cavalheirescos, como o Amadís, Parsifal ou Rei Arthur, até Joe Christmas, o misterioso K., ou o coronel Aureliano Buendía, passando por Vautrin, Madame Bovary, Julián Sorel, ou d'Artagnan. Em certas épocas, como na Idade Média e o período romântico, o culto da marginalidade se encarna em personagens fora de série; em outras, como o último pós-guerra, em anti-heróis. Em muitos casos se projeta, mais sutilmente, não na matéria, senão na forma narrativa [...]. Em uma organização sui generis do tempo, como em Proust, numa reestruturação distinta dos planos da realidade, como em Joyce ou Musil, num ritmo novo do curso da vida, como em Virginia Woolf, ou numa linguagem "marginal", como em Faulkner ou Guimarães Rosa. No caso de muitos romancistas, partindo do tema da

${ }^{73}$ VARGAS LLOSA, Mario apud CANO GAVIRIA, Ricardo. El buitre y el ave fénix, conversaciones com Mario Vargas Llosa. Barcelona: Editorial Anagrama, 1972, p. 24.

${ }^{74}$ VARGAS LLOSA, Mario. Gabriel García Márquez: historia de un deicidio, p.100. 
marginalidade, tal como aparece em suas ficções, poderia chegar-se a identificar as experiências cruciais que foram a origem de sua vocação. ${ }^{75}$

A esta formulação, Rama respondeu com a implicação social e econômica do produto literário, considerando que incluir a obra de García Márquez entre os "marginalizados" a "violenta em algumas de suas linhas centrais que explicam a multitudinária acolhida do público"76. Para Rama, a teoria de Vargas Llosa percebe a vida humana como um desgarrado conflito entre mundo e homem, no qual este é o "paciente" e não o "agente" da história, o "marginal" solitário e não o "integrado" a algum setor, grupo ou movimento, ou seja, um tipo de formulação que corresponderia a idealizações destinadas a preservar o "status" de um profissional a quem a burguesia, ao assumir a direção do mundo, retirou sua encomenda $^{77}$. Segundo Rama:

Esse marginal, movendo-se no universo individualista e competitivo recém-criado, havia desenvolvido um conjunto de teorias justificadoras, verdadeiras racionalizações de seu desânimo. Delas se apoderariam ansiosos os escritores latino-americanos, mais órfãos que seus colegas europeus, vivendo em sociedades aonde a função intelectual nunca chegou a ser hierarquizada e justificada independentemente. ${ }^{78}$

De fato, em suas formulações, Vargas Llosa não levou em consideração ou pelo menos, não as ressaltou - que o status do escritor havia passado por um processo de transformação desde os anos quarenta, com o desenvolvimento econômico das grandes cidades latino-americanas, a ampliação do público consumidor, o desenvolvimento do mercado editorial, que possibilitou a expansão comercial da narrativa e com ela a existência do fenômeno que ficou conhecido como o boom, permitindo que emergisse uma nova condição e status social do escritor. Em "El boom en perspectiva", ao abordar as novas condições de produção proporcionadas pela expansão da narrativa latino-americana, nos anos sessenta e setenta, Rama ressalta que se alcançava a tão almejada profissionalização do autor - expectativa desde a época do modernismo exigindo-lhe, em contrapartida, um aumento de produtividade. Com o aparecimento do novo público leitor, com os mercados nacionais expandindo-se

\footnotetext{
${ }^{75}$ Ibidem, p.100-101.

${ }^{76}$ RAMA, Ángel. "El fin de los demônios", p.27.

${ }^{77}$ Ibidem, p. 28 .

${ }^{78}$ RAMA, Ángel. "Demonio vade retro", p.9.
} 
para o continente e ainda para o exterior, por meio das traduções, os autores logo teriam percebido a necessidade de um regime de trabalho em conformidade com esse novo mercado, que os obrigava a produzir dentro de alguns limites preestabelecidos ${ }^{79}$.

De acordo com o crítico uruguaio, os escritores, mas principalmente os narradores, passavam de aficionados (ou amadores) a profissionais. Estes apresentavam uma maior produtividade do que os primeiros, dado verificável pelo número de obras e pelo ritmo com que os integrantes de cada uma dessas categorias produziram e colocaram suas obras no mercado. Ainda assim, tal escritor-profissional parecia incapaz de abastecer com novidades o público de massa. Verificava-se uma maior rotatividade de obras, circunstância que exigiria de alguns uma produção mais constante. Nesse movimento de expansão, segundo o autor, observaríamos uma especialização da profissão “autor”. Além do chamado "narrador-artista", encontraríamos o "narrador-intelectual" ou, mais especificamente ainda, o "narrador-ensaísta" ou "poeta-ensaísta". Estes deveriam agir como "empresários independentes", buscando modos de se inserir no mercado e adequar-se as suas flutuações. Nesse sentido, o "autor-profissional" procurava não apenas novas formas de remuneração aliada à produção escrita, como, por exemplo, proferir palestras, mas também alternativas para manter contato com os meios de comunicação de massa e divulgar sua produção ${ }^{80}$. De acordo com Rama, para chegar ao público massivo que havia substituído o público de elite, o autor tinha que transitar pelos mass media, coisa que de um modo ou de outro fizeram quase todos os narradores, inclusive os mais relutantes, por timidez a falar diante de multidões, como García Márquez e Juan Carlos Onetti $^{81}$.

Em “Resurrección de Belcebú o la disidencia creadora”, Vargas Llosa sustentou que Rama não havia compreendido um elemento central de sua tese, a saber, a vocação específica do romancista, que diferencia o romance dos outros gêneros. O escritor peruano, usando como exemplo a obra Tirant lo Blanc (1490), de Joannot Martorell, justifica suas formulações à luz da historicidade do romance e das teorias do gênero literário. Neste ponto, Vargas Llosa se afasta radicalmente

\footnotetext{
${ }^{79}$ RAMA, Ángel. "El boom en perspectiva". In: Signos Literarios, n. 01, janeiro-junho de 2005, p.193.

${ }^{80}$ Ibidem, p.204.

${ }^{81}$ Ibidem, p.205.
} 
do debate da crítica literária dos anos setenta, baseando-se numa perspectiva convencional do gênero, que analisaremos a seguir.

\section{2. \\ Uma arma chamada romance}

O título desta seção faz menção a um dos tópicos ressaltados por Ángel Rama em sua resposta ao escritor peruano, intitulada "Segunda respuesta a Mario Vargas Llosa". Trata-se do último e mais extenso artigo da polêmica, publicado em Marcha, em setembro de 1972. Rama, na abertura deste tópico, assinala que somente um discurso "documentado" pode cumprir a dupla função de uma resposta intelectual: "dissolver os erros afirmados com talento e sem provas e ir construindo uma explicação coerente dos temas em debate". O crítico uruguaio especifica que estes temas já não são os iniciais, "que teriam ficado para trás", senão "o romance como gênero e a cosmovisão; as relações do romance e a realidade; a lucidez criativa e interpretação do mundo". Sendo o primeiro destes a dimensão na qual o crítico se atém, buscando desenhar uma teoria do romance a partir de sua evolução histórica ${ }^{82}$.

As indagações a respeito da especificidade do romance surgem a partir da ressalva de Rama - em "El fin de los demônios" - quanto à aplicabilidade da teoria dos "demônios" à arte moderna de modo geral. Para o crítico uruguaio as concepções de Vargas Llosa - a saber, a vocação do romancista não se elege racionalmente; o escritor não elege seus temas, pois estes estão visceralmente mesclados aos demônios de sua vida; todos os romancistas são rebeldes - são claramente datadas, pois reporiam os conceitos "vulgarizados pela estética romântica". Nesse sentido, Rama agrega que a tese de Vargas Llosa concedia uma cota fundamental ao irracionalismo, como foi próprio da estética romântica, quando, a seu ver, acreditava-se que a vocação e os temas de um escritor eram irracionais ${ }^{83}$. Rama assinala que

não há possibilidade alguma de aplicá-las [a teoria dos "demônios"] a $E l$ sobrinho de Rameau ou ao Cándido, exemplos da arte narrativa do XVIII, porém, tampouco

82 RAMA, Ángel. "Segunda respuesta a Mario Vargas Llosa”. In: García Márquez y la problemática de la novela. Buenos Aires: Corregidor - Marcha, ediciones, 1973, p.68.

${ }^{83}$ RAMA, Ángel. "El fin de los demonios", p.26. 
às inumeráveis obras anteriores que foram feitas por encomenda, tal como constituiu a norma da arte durante milênios. Desconcerta-me imaginar como faria Vargas Llosa para estudar $A$ Eneida que Augusto pediu a Virgílio, à luz do pobre psicologismo romântico, e deve notar-se que boa parte do esforço crítico do século XX buscou desembaraçar certas obras clássicas da pátina imposta pelo romantismo, como é o caso de Shakespeare (ver-se o livro de Jan Kott), de Cervantes ou de Dante. Porém, tampouco é possível aplicar tal instrumento à arte contemporânea, apesar de esta seguir dominada pelas condições (econômicas e sociais) que impôs a burguesias ao tomar o poder após o ciclo de suas revoluções, e não creio que a evidente admiração de Vargas pela psicanálise existencial de Sartre - que não pode assimilar-se impudentemente a Sainte-Beuve - possa conduzi-lo a revisar assim Los caminos de la libertad, como penso que tampouco os romances de Brecht, ou de Calvino ou de Gunter Grass ou de Fuentes ou de Carpentier, e incluindo a obra de García Márquez, a quem me parece que, ao colocar entre os "marginalizados", violenta em algumas de suas linhas centrais que explicam a multitudinária acolhida do público. ${ }^{84}$

Em sua resposta a estas considerações, Vargas Llosa, em "Resurrección de Belcebú o la disidencia creadora", apostou na especificidade do romance, distinguindo-o das demais obras, como o teatro e a poesia. A seu ver, a vocação do romancista é algo "específico, com características próprias e distintas dentro da literatura, sendo justamente essa autonomia no que se refere às demais artes e gêneros o que o ensaio [sobre García Márquez] pretende descrever, a partir de um caso específico". Neste sentido, declara Vargas Llosa:

\begin{abstract}
Usar minha tese para estudar os versos de Virgílio, "a imensa maioria da arte universal", ou tudo o que contém esses "três mil anos de literatura", seria tão improcedente como querer estudar a geografia inteira de um país com os instrumentos idealizados para medir o volume d'água dos rios [...]. Talvez tranquilize Rama saber que, no que se refere à poesia e ao teatro, minhas ideias não são idênticas ao que se refere ao romance. Não no que se refere à intervenção do irracional, inseparável de todo processo criativo, e que, principalmente na poesia, desempenhou um papel importantíssimo, senão concretamente no que se refere a esse fator de negação, de questionamento radical, de insatisfação contra a realidade que, creio eu, é o pulso mais íntimo da vocação do romancista e das ficções que gera $[\ldots]^{85}$.
\end{abstract}

Vargas Llosa sustenta uma percepção distinta dos gêneros narrativos. Para ele, a poesia expressou muitas vezes - na voz de grandes figuras como, por exemplo, Virgílio - "a harmonia de um homem com o mundo, exaltou o estabelecido e testemunhou sobre a felicidade e harmonia da vida". Por sua vez, afirma o escritor peruano que o teatro "tem sido um excelente veículo de

\footnotetext{
${ }^{84}$ Ibidem, p.27 [tradução nossa].

${ }^{85}$ VARGAS LLOSA, Mario. [1972]. "Ressureição de Belzebu, ou a Dissidência Criadora". In: Contra vento e maré. Rio de Janeiro: Francisco Alves, 1985, p.189 (grifos do autor).
} 
propagação da fé dominante, religiosa ou política”. Por isso, a poesia e o teatro, mais do que o romance, "revelaram com mais intensidade o absolutismo e a tirania”. Para o autor, no caso do romance, sua natureza não parece admitir a submissão ao real: "a pré-fabricação ideológica o aniquila" $"$. Deste modo, sustenta Vargas Llosa:

[...] O engano de Rama procede, sem dúvida, de uma assimilação prévia e inocente de todos os gêneros, de um convencimento tácito em seu paralelismo: o que vale para o romance, vale para o teatro e para a poesia. Esta assimilação foi teorizada por Barthes e seus discípulos e é uma das minhas objeções a este ramo do estruturalismo: sua ideia de que não existem os gêneros literários, de que a noção de texto deve se confundir com a do poema, drama e romance não me convence, porque acho que os "gêneros" não obedecem a caprichos da velha retórica, mas a uma razão profunda, que cada um deles possui uma gênese distinta e propõe uma visão diferente da realidade. Abolir suas fronteiras pode causar equívocos críticos elementares. ${ }^{87}$

Vargas Llosa ressalta que é insólita a confusão de Rama porque, no capítulo II da primeira parte de seu livro sobre García Márquez, está literalmente indicado para os leitores "mais distraídos" que o autor fala de um fenômeno existente “desde que, em dado momento da história, a evolução social, econômica e cultural tornou possível e necessário que surgisse a vocação do romancista”. Assim, assinala o escritor peruano que em seu livro o termo "vocação" é acompanhado da palavra romancista, e o mesmo ocorre com o termo "criação", que é acompanhado da palavra narrativa. ${ }^{88}$

Em "Segunda respuesta a Mario Vargas Llosa", Rama considera que o escritor peruano opera com uma distinção genérica, pois nada indica que a poesia e os poetas não possam ser "deicidas", uma vez que a capacidade para um "questionamento radical" da realidade poderia ser mais evidente num autor como Baudelaire, em As flores do Mal (1857), que no O vermelho e o Negro (1830), de Stendhal. Para ele, a "insatisfação contra a realidade" é mais flagrante e até praticamente torna-se o sustento explícito de Os Cantos de Maldoror (1874), de Conde de Lautréamont, de um modo que não é perceptível na prolixa série $O s$ homens de boa vontade, de Jules Romains (1932-1947). Segundo Rama, pode-se teorizar com bastante fundamento que os grandes questionadores da realidade foram os poetas e não os romancistas: "não conheço nenhum romancista desse

\footnotetext{
${ }^{86}$ Ibidem, p. 189-90.

${ }^{87}$ Ibidem, p. 190 .

${ }^{88}$ Idem.
} 
tempo de quem se possa dizer que é pai da arte moderna como em troca se pode proclamar Arthur Rimbaud" ${ }^{89}$. O crítico uruguaio afirma que esta distinção se torna ainda mais genérica e absurda quando se separa o romance do teatro - sem recordar que são muitas vezes exercitados pelo mesmo autor - pois, não se pode falar, por exemplo, que A Resistível Ascensão de Arturo Ui (1941), de Brecht, questiona menos a realidade que o romance do mesmo autor, Os Negócios do Senhor Júlio César (não concluído) ${ }^{90}$. De acordo com Rama:

Dizer que "o teatro foi um excelente veículo de propagação da fé dominante, religiosa ou política" é fazer uma afirmação somente válida se se refere ao teatro que os poderes puseram a seu serviço ao longo da história (como puseram parcialmente os demais gêneros) [...] não foi por turismo que Shakespeare desapareceu de Londres ao fracassar a conspiração de Essex, e chegado ao tempo presente, não há instrumento de questionamento intelectual da ordem instituída que tenha mostrado maior vigor, destreza e virulência que o teatro, superando em muito os demais gêneros, em particular o sempre tardio romance. ${ }^{91}$

Para o crítico não é suficiente fixar, "por decreto voluntarioso", o raio de aplicação de uma tese estética que "nem sequer alcança" especificidade com a utilização frequente do adjetivo "narrativo". A seu ver, a tese do "deicídio" é de tal amplitude que, por vezes, não atinge o peculiar das operações criativas ${ }^{92}$. Deste modo, Ángel Rama assinala que,

\begin{abstract}
se a tese, como se vê, pode aplicar-se indiscriminadamente a qualquer matéria literária, carece de especificidade narrativa que o autor pretende atribuir-lhe e, ainda, poderia suspeitar-se que até carece de especificidade literária. Isso é ao menos, o que apontou um excelente crítico peruano, José Miguel Oviedo, quem em um comentário - os demais muito elogiosos - sobre o livro de Vargas Llosa, conclui o raciocínio: "Ademais, por que unicamente escrever romances é um ato deicida, uma suplantação de Deus? Não poderá sê-lo também pintar quadros, escrever poesia, compor música? A "teoria" pode abarcar tanto que já começa a conter pouco". Penso que se o autor confere caráter especificamente "narrativo" a sua tese é, outra vez, para não reconhecer a dependência da história e dos períodos culturais que nela se elaboram, onde se determinam valores que regem o conjunto literário, bem acima do genérico. ${ }^{93}$
\end{abstract}

Rama enfatiza que Vargas Llosa utiliza uma concepção primária sobre os gêneros, uma vez que a crítica moderna já havia estabelecido que o definidor do gênero narrativo não responde ao uso do verso ou da prosa, senão ao contar

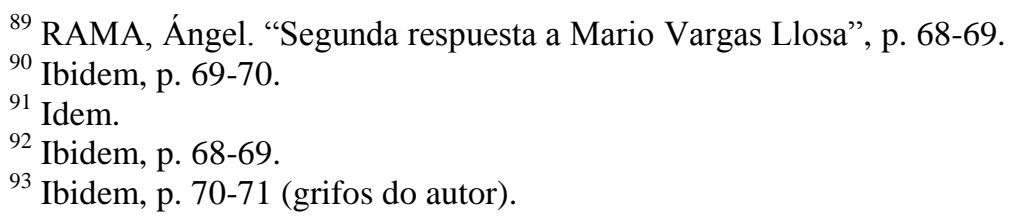


narrativo e a sua ilusão de objetividade. De acordo com o crítico uruguaio, tal enfoque sobre sua essência e não sobre seu meio - desenvolvido pela própria estética romântica - corroborou com a "legitimidade da passagem peculiar da modernidade", possibilitando o trânsito da "poesia dramática" dos clássicos ao teatro em prosa, e da "poesia épica" clássica e medieval ao moderno romance em $\operatorname{prosa}^{94}$.

Rama ressalta que a "discussão acerca dos gêneros literários é tão antiga como, pelo menos, os textos de Aristóteles", ou, ao menos durante três séculos, do XVI ao XVIII, o debate sobre os gêneros promoveu autênticas batalhas intelectuais, cujos epicentros passaram da Itália à França, com a participação de centenas de teorizadores, passando das classificações a sua imposição preceptiva. Para Rama, "aos mestres aferrados ao tema dos gêneros devemos alguns dos esplendorosos erros da história literária [...], o que tornou compreensível a geral insurreição que registrou o romantismo". Deste modo, o debate romântico cancelou os deslindes classificatórios, dando "um grito de liberdade (de liberalismo)" que aboliu as rígidas cartilhas e reconheceu como legítimos gêneros que seguiam estigmatizados como "bastardos", "ignóbeis", "grotescos" ou "mistos", como foi o caso do romance moderno. Trata-se, na percepção de Rama, do triunfo de "certa vulgaridade" que, vencidos os aristocratas - "numa revolucionária substituição de classe" -, se regozijou em gêneros novos como o "melodrama" ou o "folhetim narrativo"95. De acordo com Rama, "o grito de liberdade" dos românticos possibilitou que a arte moderna praticasse intensamente a mescla dos gêneros: "inventou o que necessitava para seu trabalho criativo e obrigou que a crítica, mesmo a dos manuais (penso nos Kayser ou Wellek e Warren [...]), se retraísse de todo ditame rígido"96.

Com o Romantismo a noção de gêneros é substituída por outra que considera os gêneros intercomunicantes; ao invés do caráter normativo, segue-se uma teoria "manifestamente descritiva". Como assinala Wellek e Warren, supõese, por exemplo, que os gêneros tradicionais podem "mesclar-se" e produzir um novo gênero como a tragicomédia, resultante da combinação entre a comédia e a

\footnotetext{
${ }^{94}$ Ibidem, p.71.

${ }^{95}$ Ibidem, p.75

${ }^{96}$ Ibidem, p.76.
} 
tragédia ${ }^{97}$. Pode-se considerar que a libertação da perspectiva clássica não significou um esquecimento do problema dos gêneros, mas que este adquiriu novos matizes, como se vê na Estética (1832-1845) de Hegel, que seria posta em cheque com o avanço das ciências da natureza na segunda metade do século XIX. Assim, os gêneros passam a ser considerados como autênticos seres vivos, nascem, crescem e morrem, sujeitos às mesmas leis da evolução que regem a existência de todo ser biológico, estudados à luz das teorias evolucionistas preconizadas, sobretudo por Herbert Spencer no campo social.

O apoio das ciências da natureza na questão dos gêneros denotou, como assinala Massaud Moisés, uma espécie de ressureição do passado clássico, o que provocou a imediata repulsa de Benedetto Croce, num estudo acerca de La Critica Letteraria. Questioni Teoriche (1894), mais tarde recolhido em Primi Saggi (1918); a que se seguiu Estetica come Scienza dell'espressione e Linguistica Generale (1902), Breviario d'Estetica (1912) e La poesia (1936), onde o autor acusa os gêneros de serem classificações mais ou menos arbitrárias dos velhos $\operatorname{tratadistas}^{98}$. Para Croce, "entre o universal e o particular não se interpõe filosoficamente nenhum elemento intermédio, nenhuma série de gêneros ou de espécies, de generalia" 99 . Rama refere-se ao livro La poesia, especificamente o capítulo "El anquilosamiento de los gêneros literários y su dissolución", para sustentar que Croce já havia observado a esclerose da perspectiva literária fecundada pelo historicismo do XIX, que gerou uma segunda deformação da história por gêneros. De acordo com o crítico uruguaio, Croce ressalta o absurdo deste tipo de perspectiva assinalando que o protagonista da história da poesia havia deixado de ser a própria poesia, para tornar-se o gênero ou os gêneros. Para Rama, similar operação cumpre Vargas Llosa ao recortar o gênero (narrativo) do conjunto da literatura, reinstaurando a compartimentação da percepção do XIX, "quando esta tratou de modernizar-se, porém sem renunciar a retórica tradicional" 100 .

Em Ruptura dos gêneros na literatura latino-americana (1972), Haroldo de Campos assinala que, na América hispânica, o momento efetivo dessa ruptura

${ }^{97}$ WELLEK, René; WARREN, Austin apud MOISÉS, Massaud. Dicionário de termos literários. 12.ed.rev e ampl. São Paulo: Cultrix, 2004, p. 198.

${ }^{98}$ MOISÉS, Massaud, op. cit., p.198.

${ }^{99}$ CROCE, Benedetto apud MOISÉS, Massaud, op. cit., p.198.

${ }^{100}$ RAMA, Ángel. "Segunda respuesta a Mario Vargas Llosa", p. 76. 
da ideia de gêneros e de seu exclusivismo linguístico - sobretudo no que tange às grandes divisões das categorias poesia e prosa - é marcado pelo Modernismo de Rubén Darío e seus companheiros. O Modernismo de língua espanhola (que, cronologicamente, corresponde ao Parnasianismo e ao Simbolismo brasileiros, embora nem sempre de maneira esteticamente simétrica), foi resumido por Octavio Paz como reforma verbal. De acordo com Paz:

O modernismo foi uma sintaxe, uma prosódia, um vocabulário. Seus poetas enriqueceram o idioma com cargas do francês e do inglês; abusaram de arcaísmos e neologismos; e foram os primeiros a empregar a linguagem da conversação. Por outra parte, se esquece com frequência que nos poemas modernistas aparece um grande número de americanismos e indigenismos. Seu cosmopolitismo não excluía nem as conquistas do romance naturalista francês nem as formas linguísticas americanas. Uma parte do léxico modernista envelheceu como envelheceram os móveis e objetos da art nouveau: o resto entrou na corrente da fala [...]. ${ }^{101}$

Haroldo de Campos assinala que, superada a rígida tipologia intemporal, "com propensões absolutistas e prescritivas", a teoria dos gêneros passou, na poética moderna, a constituir um instrumento operacional, descritivo, dotado de relatividade histórica, e que não tinha por escopo impor limites às livres manifestações da produção textual em suas inovações e variantes combinatórias. Neste sentido, se dissolve a ideia de gênero como categoria impositiva, relativizando-se também a noção de uma linguagem que lhe seria exclusiva, que lhe serviria de atributo distintivo ${ }^{102}$.

Voltando a Ángel Rama na polêmica com Vargas Llosa, o crítico uruguaio sustenta, à luz das formulações de Octavio Paz, que as semelhanças artísticas são dadas de modo mais integral num plano sincrônico que num decurso diacrônico. Assim, do mesmo modo que para Octavio Paz parecia "discutível a existência de uma poesia francesa, alemã ou inglesa", porém não "a realidade da poesia barroca, romântica ou simbolista”, poderia notar-se que as similitudes estéticas respondem menos à utilização de um gênero (narrativo, lírico, dramático) que a estética de uma determinada época que impregna a totalidade criativa. Neste sentido, Rama afirma que o romance de García Márquez se parece mais com a poesia de Álvaro Mutis (1923-2013) que a narrativa de José Eustaquio Rivera (1888-1928); ou, que

101 PAZ, Octavio apud CAMPOS, Haroldo de. "Ruptura dos gêneros na literatura latinoamericana”. In: FERNÁNDEZ MORENO, César (coord.). América Latina em sua literatura. São Paulo: Perspectiva, 1972, p. 290.

${ }^{102}$ CAMPOS, Haroldo de, op. cit., p.282-283. 
a poesia de Juan Parra del Riego (1894-1925) não se parece com a de Juan Ramón Jiménez (1881-1958), senão com a contística de Felisberto Hernández (19021964) ${ }^{103}$.

De acordo com o crítico uruguaio, é a obra dos formalistas e estruturalistas quem, ao revés do que afirma Vargas Llosa, começou a reconstruir o edifício dos gêneros, em particular o narrativo, o que resultava previsível dentro de sua reinstauração da retórica, ainda que, neste caso, os gêneros sejam compreendidos de forma mais ampla que as categorias anteriores devido aos avanços da semiologia ${ }^{104}$. A seu ver, do mesmo modo que os surrealistas reinstalaram o "fazer poético" num marco mais amplo que o da poesia, os estruturalistas, trabalhando sobre as linguagens derivadas da literatura, situaram o funcionamento do "relato", suas unidades e combinações no enclave mais generalizado e abstrato possível. Para Rama, os trabalhos de Umberto Eco, Tzvetan Todorov, Algirdas Julien Greimas, entre outros, contribuíram para esta reconstrução de uma especificidade narrativa, embora, "dado o enfoque de seus autores, ela não implica senão raramente uma cosmovisão, mas sim uma ideologia definida" ${ }^{105}$.

Pode-se notar a partir da resposta de Rama, em seus diversos recortes referenciais, que a perspectiva dos gêneros narrativos de Vargas Llosa vai de encontro ao debate epistemológico da literatura nos anos setenta. Podemos perceber, ainda que numa breve aproximação, as questões que estavam em jogo no debate sobre o corpus literário latino-americano nos textos produzidos tanto na década de setenta, como naqueles que, publicados posteriormente, empreenderam uma revisão dos debates. Sobre este aspecto, o crítico peruano Antonio Cornejo Polar ressalta, em "Para una teoria literaria hispanoamericana: a veinte años de un debate decisivo" (1999), que qualquer referência à literatura hispanoamericana "remete inevitavelmente ao grande debate dos anos 70, surgido a partir da proposta de produzir uma teoria realmente nossa, em concordância com a especificidade de uma literatura que por então gozava de seu primeiro êxito internacional massivo [...]"106. Independentemente do fracasso desse projeto inicial, segundo a constatação de Cornejo Polar, o elemento decisivo da discussão

\footnotetext{
${ }^{103}$ RAMA, Ángel. "Segunda respuesta a Mario Vargas Llosa”, p.77.

${ }^{104}$ Ibidem, p.78.

${ }^{105} \mathrm{Idem}$

${ }^{106}$ CORNEJO POLAR, Antonio. "Para una teoria literaria hispanoamericana: a vinte años de un debate decisivo". Revista de Critica Literaria Latinoamericana, ano XXV, n.50, Lima- Hanover, $2^{\circ}$ semestre de 1999, p. 9.
} 
havia sido a evidência da necessidade de modificação radical do conceito de literatura na América Latina ${ }^{107}$. Ou seja, nas palavras do crítico peruano, o que “estaria em jogo é um câmbio na construção epistemológica do 'objeto' literatura" 108 .

O que precisamente nos interessa na formulação de Cornejo Polar é a noção de ampliação do corpus literário para incluir outros discursos, como por exemplo, a literatura oral em quéchua ou aymara que se produz em países como Bolívia, Equador e Peru. Certamente, isto significava uma ampliação de um conceito restritivo da literatura, que condicionava sua existência à escrita, ao idioma europeu e aos códigos estéticos derivados da alta literatura europeia. O que implicava, segundo Cornejo Polar, passar do conceito de unidade (e de uma identidade nacional mais ou menos metafísica) a outro que desse conta da diversidade heterogênea e contraditória que poderia se dar inclusive num só texto, como por exemplo em textos do período colonial, como Nueva crónica y buen gobierno (1615), de Felipe Guaman Poma de Ayala, ou em textos modernos e experimentais como El zorro de arriba y el zorro de abajo (1971), de José María Arguedas.

Cornejo Polar assinala que deveríamos ter em mente que o que chamamos de literatura é um objeto social e culturalmente construído, e nessa mesma medida é um objeto histórico, mutável, cambiante, evasivo como poucos. A este respeito, bastaria recordar que a poética neoclássica incluía a história, a oratória e certos tipos de cartas dentro do marco da literatura como gêneros literários indiscutíveis, enquanto as poéticas baseadas nos conceitos de autonomia estética ou autorreferencialidade da linguagem literária excluíam estes gêneros e os colocava fora do âmbito da literatura. Desse modo, declara Cornejo Polar:

\footnotetext{
${ }^{107}$ Para Cornejo Polar, a evidência deste fracasso estaria na constatação de que vinte anos após o início dos debates não tínhamos uma teoria literária hispano-americana, isto porque, entre outras razões, as discussões estavam localizadas num nível muito abstrato (não a crítica, senão a teoria) que entrava em paradoxo conflito com as próprias urgências de especificidade histórico-social. Porém o problema maior, a seu ver, houvera sido a suposição de que a literatura latino-americana era uma e coerente, e que transportava ou expressava os signos de uma identidade também pensada em termos globalizantes. Se tratava de construir uma teoria que desse inteira razão de uma literatura, em certo sentido, seguindo o grande projeto de Pedro Henríquez Ureña, que se sintetizava em sua frase emblemática: "em busca de nossa expressão". Para o autor, o projeto todo entrou em crise quando começou a impor-se, anos depois, uma imagem variada e multiforme da literatura latino-americana. "Sua condição múltipla, plural, híbrida, heterogênea ou transcultural dos distintos discursos e dos vários sistemas literários que se produzem em nossa América". (Ibidem, p.9-10).

${ }^{108}$ Ibidem, p.11.
} 
[...] O que quero enfatizar é que a construção do tantas vezes mencionado "objeto" (da nossa literatura) não depende somente de uma opção própria da teoria literária, senão, também, sobretudo, de uma opção inelutavelmente política acerca de quem (e quem não) forma parte de "nossa América". ${ }^{109}$

Para o crítico peruano, o emprego de categorias tais como transculturação, pluralidade, heterogeneidade, hibridez, etc., supõe um exercício teórico destinado em última instância a modificar radicalmente o conceito de literatura latinoamericana, porém, não como resultado de uma proposta mais ou menos abstrata $\mathrm{e}$ voluntarista, senão como resposta às novas maneiras de ler nossa literatura, precisamente no que parece caracterizá-la com maior contundência: "a copiosa rede de conflitos e contradições sobre o qual se tece um discurso excepcionalmente complexo"110. Complexo porque é produzido e produz formas de consciência dispares, às vezes, entre si, incompatíveis; porque entrecruzam discursos de várias procedências e contexturas, supondo ainda uma história feita de muitos tempos e ritmos.

Em Para una teoría de la Literatura Hispanoamericana (1973), publicado na revista Casa de las Américas, o crítico cubano Roberto Fernández Retamar argumenta que a literatura na América Latina seria portadora de um dos traços que detonam a especificidade da literariedade, pois o propriamente latino-americano seria caracterizado por uma espécie de hibridez, onde predominam os gêneros "ancilares" (crônicas, discursos, ensaios, diários, testemunhos, relatos que lidam com a história e o discurso doutrinal, etc.). Neste ensaio, Fernández Retamar apontava para a necessidade de uma "autêntica teoria da literatura latinoamericana", capaz de enfrentar a "invasão meta-teórica e teórica europeia" que postulava, em muitas de suas versões, a universalidade de suas aplicações metodológicas. Em 1975, num segundo ensaio, intitulado Algunos problemas Teóricos de la Literatura Hispanoamericana, o crítico cubano reafirmava e ampliava suas concepções no que se refere à necessidade de uma "verdadeira teoria da literatura latino-americana”. Para Fernández Retamar, a literatura produzida no continente era um aparato descolonizador, pois expressava os problemas e os valores latino-americanos, porém era lamentável a ausência de

\footnotetext{
${ }^{109}$ Idem.

${ }^{110}$ Ibidem, p. 12
} 
estudos que sustentassem esta visão descolonizada ${ }^{111}$. Estes dois ensaios deram origem ao livro Para una teoría de la literatura hispanoamericana y otras aproximaciones, publicado em 1975, no qual Fernández Retamar afirmava que as teorias da literatura hispano-americana não poderiam forjar-se nos critérios das "literaturas metropolitanas", pois estes critérios haviam sido propostos a partir de uma concepção de validade universal, que representava a manifestação do colonialismo cultural como sequela do colonialismo político e econômico. A seu ver, "frente a esta pseudo universalidade, temos que proclamar a simples e necessária verdade de que uma teoria da literatura é a teoria de uma literatura", ou seja, a "literatura universal" não é uma literatura, senão o resultado da visão triunfal da globalização pretendida pelo capitalismo. Portanto, deveria existir uma teoria que estudasse a literatura hispano-americana como um fenômeno autônomo $^{112}$.

A partir destas considerações poder-se-ia dizer que o que estava em jogo no debate não era apenas uma questão epistemológica da literatura, mas toda uma forma de convívio social e reconhecimento político-cultural. Voltando ao debate entre Vargas Llosa e Ángel Rama, juntamente com a noção de gênero, outra formulação relacionada à historicidade do romance esteve em pauta nas discussões. Em "Resurrección de Belcebú o la disidencia creadora", Vargas Llosa sustentou que o romance é o mais "histórico" dos gêneros, porque "diferentemente da poesia ou do teatro, cuja origem se confunde com a de todas as civilizações, possui data e local de nascimento" ${ }^{113}$. O escritor peruano situa este momento na Alta Idade Média Ocidental, quando “morria a fé, e a razão humana iria substituir a Deus como instrumento de compreensão da vida e como princípio

111 FERNÁNDEZ RETAMAR, Roberto "Para una teoría de la literatura Hispanoamericana". In: Para una teoría de la literatura hispanoamericana y otras aproximaciones. Bogotá: Instituto Caro y Cuervo, 1995, p.44.

${ }^{112}$ Ibidem, p.131. Fernández Retamar, assim como Ángel Rama, compreendia a literatura como mediadora das práticas sociais, buscando uma articulação do corpus literário com a perspectiva histórico-política. Porém, Rama percebia nas concepções de Fernández Retamar um pragmatismo isolacionista, e considerava o livro Para una teoría de la literatura hispanoamericana y otras aproximaciones como "um dos maiores erros cometidos em matéria de crítica: "postular a existência de uma Teoria Literária que, como tal, é uma regra geral, porém que somente rege para a literatura latino-americana". (RAMA, Ángel apud DÍAZ CABALLERO, Jesús. Angel Rama o la crítica de la trasculturación. Ultima entrevista. Lima: Lluvia Editores, 1991.p. 22). Em Diez problemas para el novelista latinoamericano, Rama ressaltou que a América Latina é parte do fenômeno civilizador Ocidental, daí que ao se referir aos problemas específicos dos romancistas latino-americanos, muitas vezes se refere às problemáticas literárias de toda comarca civilizada, embora a partir da parcialidade ou da inflexão que lhe é própria. (RAMA, Ángel. "Diez problemas para el novelista latinoamericano", p.5).

${ }^{113}$ VARGAS LLOSA, Mario. "Ressureição de Belzebu, ou a Dissidência Criadora”, p.190. 
reitor para o governo da sociedade" ${ }^{114}$. Rama sustenta, em sua resposta a esta questão, que todos os gêneros e não somente o "romance", na medida em que se trata de intervenções culturais, são históricos e pelo menos datáveis, o que se pode fazer com maior ou menor dificuldade. Nesse sentido, o crítico uruguaio ressalta que nem todas as civilizações registraram a existência de alguns gêneros, por isto, não se pode dizer que o teatro se confunda com a origem de todas as civilizações $^{115}$.

Em relação à periodização de origem do romance na Alta Idade Média, Rama considera incerta a formulação de Vargas Llosa. De acordo com o crítico uruguaio, "quiçá Vargas Llosa se refira a Baixa Idade Média onde igualmente é impensável que morreu a fé, porém, onde ao menos surgem os contistas ou "novelieri'", antecedentes dos romancistas europeus que recém se difundem no Renascimento, "dado que este é o grande período de crescimento do romance pastoril e de cavalaria que servem de antecedente à real invenção do romance moderno, que está toda posta entre as mãos de Cervantes"116. Ainda que, segundo ele, em alguns produtos da Antiguidade, como o fragmentário Satírico, possamos localizar algumas aproximações com o romance em prosa.

Para Rama, a constituição do romance moderno em prosa se localiza historicamente na linha ascendente do barroco, ao qual, ao concluir o período renascentista, correspondeu assumir o universo criado pela sociedade europeia. De acordo com o crítico uruguaio, seria aventureiro falar da morte da fé, mesmo nos momentos renascentistas, onde "a quebra da unidade religiosa não fez senão avivar os fogos celestiais de um e outro lado, e nos proveu dos melhores momentos da mística e do asceticismo", e ainda, "as mais brilhantes traduções bíblicas, a energia missionária mais alucinada e cruel, a arte do claro e escuro e novas formas literárias, como o auto sacramental". Porém, "se não quebrou a fé", afirma Rama, tornou-se mais complexa a estrutura social e, portanto, a cultura, com a notória emergência de um grupo (os burgueses) num processo de gradual ascensão dentro da dominante aristocracia-eclesiástica da sociedade, cujas condições de vida e propósitos conduziam fatalmente a uma colisão com os poderes em um prazo imprevisível. Este grupo, que formavam os burgueses,

\footnotetext{
${ }^{114}$ Idem.

${ }^{115}$ RAMA, Ángel. "Segunda respuesta a Mario Vargas Llosa”, p.73-74.

${ }^{116}$ Ibidem, p.79.
} 
descobriu no gênero literário mais vulgar de seu tempo a possibilidade de uma arma de combate de extraordinária eficácia no campo da cultura, colocando-o a serviço de um projeto de luta e dominação ${ }^{117}$. Segundo Rama, o romance,

[...] tão sabiamente foi assumido e reelaborado [...] para tal fim, que não havia passado dois séculos da aparição do Quixote quando permitiu a violenta expansão do romance romântico-realista que acompanhou o triunfo universal da burguesia e já então apareceu selado de um modo tão exclusivo que até hoje as classes sociais substituintes (como o proletariado neste último meio século) não encontraram como modificá-lo substancialmente, fora de fugazes acomodações documentalistas ou retornos a epicidade originária. ${ }^{118}$

Em "Diez problemas para el novelista latinoamericano" (1964), quando enfoca especificamente o romance na América Latina, Rama sustenta uma visão aproximada da que descreve no debate com Vargas Llosa. Segundo o crítico uruguaio, o gênero romance, desde suas origens, como em El Periquillo Sarmiento (1816), de José Joaquín Fernández de Lizardi (ou ainda com seus primórdios remontados à época das crônicas), teria enfrentado a realidade de diferentes modos e em distintos sistemas de expressão formal, correspondentes aos diferentes tempos. Para Rama, a perseverança desse gênero teria sido fruto de suas origens burguesas revolucionárias, quando era utilizado como instrumento de combate. No século XIX, essa característica do romance na América Latina tornar-se-ia evidente. Entretanto, argumenta o crítico, teriam ocorrido mudanças no que chama de "filosofia do romance" - o que em Transculturación da narrativa en América Latina (1982) nomeia como "ideologias" ou "cosmovisão" -, na medida em que se davam transformações na sociedade. Ao mesmo tempo, poder-se-ia verificar a convivência de mais de uma filosofia num mesmo tempo, isto é, uma variedade de tipos de romances, o que configuraria, por sua vez, uma densidade literária ${ }^{119}$. No tópico intitulado "La novela, género burgués", Rama afirma que a burguesia e o romance teriam ao longo do tempo caminhado paralelamente, inclusive em sua origem urbana. A continuidade do romance como gênero estaria diretamente condicionada à sua capacidade de transformação ${ }^{120}$.

No debate com Vargas Llosa, o crítico uruguaio sustenta que as categorias "hagiografia, pastoril, cavalaria" eram as formas exitosas que havia adotado o

\footnotetext{
${ }^{117}$ Ibidem, p.80.

${ }^{118}$ Ibidem, p.80-81 (grifo nosso).

${ }^{119}$ RAMA, Ángel. "Diez problemas para el novelista latinoamericano", p. 4-5.

${ }^{120}$ Ibidem, p.64-72.
} 
incipiente romance nos séculos XV e XVI, criando nesses casos, e, particularmente, na temática cavalheiresca, um produto híbrido movido por uma interna contradição:

por um lado, implicava a conversão da poesia épica (especialmente francesa) a formas do discurso prosístico, enquanto que, por outro, buscava sustentar a tendência arcaizante que dentro da Europa desenvolveu o sistema espanhol para prolongar a vida do pensamento medieval. ${ }^{121}$

Para Rama, o que Vargas Llosa não percebeu ao se proclamar como um "porta-estandarte" e exímio defensor do romance de cavalaria, como por exemplo em seu ensaio sobre Tirant lo Blanc, de Joannot Martorell, é que esse produto já estava deslocado em seu tempo, dada a sua incapacidade de unificar pensamento e escritura, condenando-o à extinção por não responder ao projeto cultural dos novos grupos ascendentes ${ }^{122}$.

Ángel Rama ratifica que a própria historiografia, seguindo o pensamento do filólogo e historiador cultural Américo Castro Quesada, já havia demonstrado que era através da imersão no barroco do XVII que se produziu a modificação central que na literatura gerou o "romance moderno" e, em geral, toda a arte pertencente ao moderno. Segundo Rama, a uma mesma conclusão parecia ter chegado Michel Foucault, quando organizando os estratos de sua arqueologia do saber, encontra neste mesmo período o processo de substituição da "velha episteme" pelo pensamento clássico, o que se produz numa dimensão mais vasta que a filosófica, pois modifica o sistema do conhecimento global da sociedade e o comportamento de todos os seus setores ${ }^{123}$.

$\mathrm{Na}$ perspectiva de Rama, o romance em prosa desenvolvido e ajustado progressivamente ao projeto de dominação concebido pela burguesia implicava a destruição metódica da fortaleza aristocrática, porém, quando chega o momento de seu triunfo, o romance é abandonado às impulsões próprias da estrutura econômica geral que os ingleses põem em funcionamento no século XVIII. Neste sentido, Rama declara:

Por isso, penso que quando Goldmann (com a leitura de Lukács e Girard) recorre à ideia do romance como busca degradada de valores dentro de um universo também

\footnotetext{
${ }^{121}$ RAMA, Ángel. "Segunda respuesta a Mario Vargas Llosa”, p.81.

${ }^{122}$ Ibidem, p.82.

${ }^{123}$ Ibidem, p.84.
} 
degradado, somente pode aplicar esta definição ideológica a um período histórico estritamente marcado, em que se produziu essa degradação [...]. Apontaríamos, assim, ao período do ótimo XIX, o que é corroborado com a segunda tese goldmaniana que interpreta a "forma romance" como a transposição "da vida cotidiana, dentro de uma sociedade individualista, nascida da produção para o mercado". É, também, esse o período histórico em que estava em crise o problema das dissidências a que se refere Vargas Llosa, constituindo-as nas origens do impulso criativo. Não parece haver refletido suficientemente que não há "dissidências" sem "coincidências", que são termos que se implicam e sustentam mutuamente quando pensamos os problemas de forma global ou social, e não individual. ${ }^{124}$

Por último, o crítico uruguaio aponta que o pressuposto do próprio "romance moderno" não é filho da "dissidência" de algum escritor a respeito de uma concepção cultural vigente e oficializada pelo sistema imperante, senão de sua "coincidência" com uma modificação da episteme do Ocidente, o que não se trata de feitos isolados, pois significa modificar os pressupostos da cultura, as formas do saber e do conhecimento, os valores, as ordens da arte e das letras. O que, a seu ver, tampouco poderia ocorrer sem o encontro prévio de uma transformação radical do sistema econômico ${ }^{125}$. Nesse sentido, para Rama, a tese sobre a vocação do romancista proposta por Vargas Llosa, além de conter insuficiências gerais, tampouco serve "para situar o projeto literário dentro do mundo atual, por sua visível desatenção do escritor enquanto partícipe de uma sociedade e de uma estrutura de classe", vista sua "fixação" sobre a função individual da criação ${ }^{126}$. Para Rama, como assinalado anteriormente, a tese de Vargas Llosa resulta pouco apta para atender a demanda dos setores sociais latinoamericanos que apresentavam projetos transformadores. Estes projetos seriam, na perspectiva do crítico uruguaio, observados a partir da consideração da organização em classes das sociedades latino-americanas. De acordo com Rama:

Se bem todas as classes que a compõem são transportadoras de cultura, ou seja, existem graças a uma determinada cultura que lhes é própria, na qual elaboram sem cessar de conformidade com seus recursos e que dentro da literatura cumpre sempre uma função, por atrofiada que às vezes pareça para certos níveis superiores de exigência, a situação desigual dessas classes na pirâmide social se traduz num desigual manejo e disponibilidade dos bens culturais globais da sociedade que integram. Ademais, dentro das classes inferiores ou dependentes, não todas apresentam demandas aos detentores do poder - e através deles ao conjunto social -, sendo as mais ativas as que começaram a ascender à pirâmide. São as mesmas que no conjunto marginal desenvolveram maiores potencialidades culturais. Suas

\footnotetext{
${ }^{124}$ Ibidem, p.85-86.

${ }^{125}$ Ibidem, p.86-87.

${ }^{126}$ Ibidem, p.59-60.
} 
demandas buscam basicamente cobrir suas necessidades de crescimento, coisa que somente podem alcançar através de projetos transformadores que tendem a modificar a totalidade social, ou ao menos, sua distribuição interna, porém, sendo demandas de caráter econômico e social é forçoso que passem através de formulações políticas e acarretem, simultaneamente, uma mudança nas concepções culturais, já que seria inimaginável uma transformação na infraestrutura da sociedade que não repercutisse no sistema de valores e na constelação de imagens e formas da esfera cultural. Diria mais: a única apresentação de uma demanda reivindicativa por um setor social é índice da afirmação tácita de uma nova concepção cultural projetada, a que começa a tornar-se coerente graças a sua exercitação na luta por realizá-la. Nesse processo de um setor social se vai desenvolvendo uma nova concepção cultural e, portanto, uma nova literatura, já que esta somente pode trabalhar a partir de uma estrutura que foi previamente desenvolvida no campo cultural. ${ }^{127}$

Com base em concepções que articulam intensamente a literatura à sociedade - sem que isso signifique um determinismo social sobre a produção literária -, Rama ressalta que as vicissitudes de uma nova demanda social correspondem às exigências vitais de um extenso setor das baixas classes médias e de alguns setores de trabalhadores que se comportavam de maneira similar, transformando as concepções vigentes sobre a cultura. Para Rama, as curvas ascendentes da natalidade, o processo de urbanização violenta, o desenvolvimento industrial amparado pela contenda mundial, o crescimento dos serviços estatais e o avanço progressivo dos planos educativos, ou seja, diversos indicadores vinham anunciando visivelmente a formação de um importante grupo social que havia de colocar, em curto prazo, suas reivindicações. Estas adquiriram sua maior virulência na zona juvenil dos novos setores. Segundo Rama,

não é por azar que os conflitos da última década tiveram como cenário as universidades latino-americanas e, ainda, os secundários [correspondente para nós ao ensino médio], e que a oposição em satisfazer as demandas colocadas conduziram aos trágicos enfrentamentos do ano de 1968 (de Tlatelolco à Líber Arce), servindo para datar uma nova época que será tanto da sociedade como de sua cultura. ${ }^{128}$

Posteriormente, em "El boom en perspectiva", texto no qual analisa a expansão da narrativa latino-americana dos anos sessenta e setenta, Rama irá sustentar que o fenômeno era parte de um processo de expansão tecnológica e cultural, levantando os mesmos índices que havia sustentado no debate com Vargas Llosa. Para ele, neste momento, houve um fracionamento do público, que

\footnotetext{
${ }^{127}$ Ibidem, p.60-61.

${ }^{128}$ Ibidem, p. 64.
} 
passou a exigir produtos culturais diversificados - distintos tipos de literaturas e, portanto, de produtos livros. Dessa forma, tornou-se necessária uma equipe profissional para suprir tal demanda ${ }^{129}$. Rama sustenta que, na polêmica com Vargas Llosa, o paradoxo das formulações do escritor peruano residia no fato de que seus romances tendiam a aceitar e incorporar as transformações sociais, porém, sua tese da vocação do romancista tendia a negá-las ${ }^{130}$.

O debate entre Vargas Llosa e Ángel Rama a respeito do livro Gabriel García Márquez: historia de un deicidio (1971) evidencia duas concepções distintas sobre o papel político-social da literatura e do escritor. Trata-se de um tema importante na trajetória intelectual de ambos os polemistas que, ao longo da discussão, atravessam o pensamento sobre a modernidade latino-americana e seu sistema cultural. Ao longo de sua trajetória crítica, Rama buscou compreender a nova fase que os intelectuais, incluindo ele, viviam na sociedade latino-americana. Podemos dizer que grande parte de sua obra refere-se à postura dos intelectuais quanto a sua nova função diante das alterações provocadas pela modernidade ${ }^{131}$. O crítico uruguaio repensou e criou vários conceitos, como os de comarca cultural, generación crítica, transculturación narrativa, que tiveram significativa projeção no campo dos estudos da cultura latino-americana. O intelectual não apenas desenvolveu cada vez mais seus estudos pensando no subcontinente de modo integral como publicou ensaios e participou de congressos em vários países da América Latina, da Europa, e nos Estados Unidos ${ }^{132}$. A educação também foi um dos temas recorrentes na crítica de Rama, como se pode notar em seu artigo, da década de setenta, "La estructura de la Universidad a la hora del cambio", onde assinala a interdependência entre as estruturas universitárias e a sociedade global $^{133}$.

\footnotetext{
${ }^{129}$ RAMA, Ángel. "El boom en perspectiva", p. 197.

${ }^{130}$ RAMA, Ángel. "Segunda respuesta a Mario Vargas Llosa", p.66.

${ }^{131}$ Esta preocupação se fazia presente em diversos artigos publicados em Marcha, como também nos ensaios Rubén Darío y el modernismo (1970), Los gauchipolíticos rio-platenses. Literatura y Sociedad (1976), "El boom en perspectiva" (1979), Tranculturación narrativa en América Latina (1982), assim como em algumas publicações póstumas - a saber, La ciudad letrada (1984) e Las máscaras democráticas del modernismo (1985).

${ }^{132}$ Nos anos cinquenta, Rama iniciou sua aproximação com a Universidade. Nesta época, também era professor do que hoje chamamos de ensino médio, além de trabalhar na Biblioteca Nacional de Montevidéu (1949-1965). (CUNHA, Roseli Barros, op. cit., p.21-22).

${ }^{133}$ Conforme Cunha, em 1967 Rama participou do seminário Universidad de la República, em Montevidéu, sobre "Estructuras Universitarias", dirigido pelo antropólogo brasileiro Darcy Ribeiro. Alguns anos depois, publicou o artigo "La estructura de la Universidad a la hora del cambio". (Ibidem, p.22).
} 
Com efeito, podemos dizer que a verdadeira obsessão do trabalho crítico de Rama era sua preocupação com questões relativas à América Latina, e que esta se expressava no fato de ele se debruçar criticamente nas diversas manifestações culturais do continente, na descoberta de novos autores, na integração que buscou entre os países da América Latina, na sua aproximação com os porto-riquenhos e com o Brasil, e ainda na revisão da história literária do continente. As concepções de Rama se traduziram em seus projetos editoriais, que reuniam grande parte da intelectualidade latino-americana, tais como: Fábula (primeira editora fundada por ele, em 1950, juntamente com Carlos Maggi), a editora Arca (fundada em 1962, juntamente com seu irmão Germán Rama e José Pedro Díaz), assim como na fundação, edição e colaboração em distintas revistas político-culturais como, por exemplo, Escrituras ou Marcha. Um dos projetos editoriais mais ambiciosos de Rama foi a coleção Biblioteca Ayacucho, oficializada pelo governo venezuelano, em $1974{ }^{134}$. Segundo Carolina Blixen, Rama elabora o projeto como "sendo uma vasta recuperação do passado, em grande parte perdido ou esquecido, a integração cultural é um intento revolucionário que, enquanto tal, se propõe um futuro, construindo a visão utópica de um continente e uma sociedade ideal"135.

De acordo com Cunha, em diálogo com argumento de Maribel Ortiz, a modernidade almejada por Ángel Rama na constituição de seu método crítico poderia ser considerada como uma mimetização do impasse já vivido pelos modernistas, uma "modernidade conflitiva". Por um lado, o crítico ressaltava que não se deveria esquecer que a América Latina e os latino-americanos faziam parte da cultura ocidental e, portanto, o modo de se estudar essa literatura poderia procurar recursos universais. Por outro, também percebia a necessidade de se

\footnotetext{
${ }^{134}$ De acordo com Cunha, "Rama havia chegado à Venezuela em 1972 para ministrar um curso na Escuela de Letras de la Universidad Central, quando em junho de 1973, com a eclosão de um golpe militar, não pôde retornar ao Uruguai. Nesses anos de exílio, estava a seu lado a então esposa, crítica de arte e escritora argentino-colombiana Marta Traba. Começava um longo processo de adaptação à sociedade caraquenha, marcado por uma intensa produção de artigos e ensaios para revistas e jornais, cursos ministrados em várias universidades e participações em congressos internacionais". Para poder permanecer no país, o crítico obtém em 1974 a nacionalidade venezuelana. Nesta época, desenvolve o projeto da Biblioteca Ayacucho, na qual era diretor literário e membro da junta diretora. "Entretanto, em 1979 a Universidade de Maryland contratava-o como professor-visitante e, a partir de 1980, Ángel Rama passaria a viver nos Estados Unidos. Lá permaneceria até junho de 1982, quanto tem negada a renovação de seu visto. Em 1983, vai para Paris como professor convidado da École Pratique de Hautes Études. No entanto, em novembro do mesmo ano, Rama e Traba, entre outros intelectuais, faleceriam num acidente de avião em Madrid, quando se dirigiam a Bogotá para participar do "Primer Encuentro de la Cultura Hispanoamericana" ". (Ibidem, p.345-346).

${ }^{135}$ BLIXEN, Carolina apud CUNHA, Roseli Barros, op. cit., p. 24.
} 
buscar um método que pudesse tratar das especificidades que verificava na América Latina ${ }^{136}$. Em relação ao método voltado às peculiaridades do subcontinente, a autora - à luz da crítica de Gonzalo Aguilar - assinala que no princípio dos anos setenta, Rama, assim como Antonio Candido, estava dando início a um processo em que buscaria "saídas do modernismo". Para Gonzalo Aguilar, um primeiro movimento esboçado por ambos os críticos teria sido uma tentativa de inversão dos valores propostos pelo modernismo. Aquilo que os unia era a realização de um mesmo movimento de inversão radical da hierarquia entre o cosmopolitismo e o regionalismo e o questionamento do privilégio que - desde a euforia modernizadora dos anos cinquenta - outorgava ao primeiro termo, convertendo-o no depositário de um tempo universal e desejável, com seus sucedâneos de crescimento urbano e desenvolvimento econômico-social ${ }^{137}$.

Por sua vez, Vargas Llosa defendia uma perspectiva da América Latina integrada, voltada para as características que constituíam a região, ao mesmo tempo em que enfatizava um olhar cosmopolita da literatura - neste caso, a experiência do exílio é um fator fundamental para a compreensão de seus posicionamentos. Ao longo de sua carreira como escritor-intelectual articula-se um movimento intenso entre literatura e política. Embora ele enfatizasse uma separação entre o intelectual e o criador (escritor), em sua prática discursiva ambas as perspectivas estiveram relacionadas. Vargas Llosa, nesta época, não era político, pelo menos no sentido usual da palavra. Porém, não cabe dúvida de que a política lhe interessava profundamente, seja como matéria narrativa, conforme, por exemplo, num livro como Conversación en la catedral (1969), cujo marco histórico se desenvolve no período de 1948 a 1956, durante a ditadura de Manuel Odría; ou como matéria discursiva em seus ensaios, entrevistas e artigos. $\mathrm{Na}$ entrevista concedida a Alfonso Tealdo, em 1966, o escritor peruano, ao ser questionado sobre sua ideologia política, responde:

[...] Socialista, porém com reservas doutrinárias frente ao marxismo. Não sou militante. Sou um franco-atirador político. [...] Porque, em meu caso me limitaria como escritor. Pertencer a um partido me prejudicaria. Tenho, ademais, o direito de discrepar e a literatura é uma coisa muito séria que exige dedicação total. ${ }^{138}$

\footnotetext{
${ }^{136}$ CUNHA, Roseli Barros, op. cit., p.56.

${ }^{137}$ AGUILAR, Gonzalo apud Roseli Barros, op. cit., p. 57.

${ }^{138}$ Vargas Llosa filou-se ao Partido Comunista peruano aos 18 anos de idade. Porém, cerca de um ano depois, ele rompeu com o Partido por não concordar com o dogmatismo. (TEALDO, Alfonso.
} 
Como vimos no capítulo III, Vargas Llosa se distanciou de Cuba e do socialismo progressivamente, na medida em que recrudesciam as políticas de controle econômico, social e cultural do governo cubano. Desde o início, o escritor peruano sinalizava que seu apoio a Cuba não era incondicional. $\mathrm{Na}$ medida em que a ideologia é sobreposta pela contingência, a crítica de Vargas Llosa à censura dentro do regime revolucionário e ao socialismo, de modo geral, adquire maior intensidade, até mesmo centralidade. Nesse sentido, é significativo o discurso de Vargas Llosa na sede do Acción Popular, em Lima, em 1978, publicado na revista peruana Oiga $^{139}$. A seu ver, as soluções para os problemas sociais, políticos e econômicos para serem "autênticas" deveriam ser adotadas dentro de um regime de livre informação e crítica. Este direito à crítica era compreendido por ele como a liberdade de criticar todos os níveis dos poderes - o poder político, o econômico, o militar, o eclesiástico, os meios de comunicação e os diferentes poderes que representam as diversas instituições sociais, como os sindicatos.

Vargas Llosa cita o ensaísta político francês Jean-François Revel, para afirmar que "a grande batalha do final do século XX, aquela da qual depende o resultado de todas as outras, é a batalha contra a censura $[\ldots]^{\prime 140}$. A seu ver, os países que se encontravam no outro lado do polo de um sistema de liberdade de informação eram os países socialistas - inclusive o governo peruano, que utilizou o modelo socialista-marxista para "reformar" a televisão, a imprensa e a rádio peruana $^{141}$. Na compreensão de Vargas Llosa, nos países socialistas, nos quais existiam muitas coisas úteis para "imitar", como, por exemplo, no campo da alfabetização e da educação, na saúde pública, nos esportes e no barateamento e

\footnotetext{
"Cómo atrapar al ángel". In: COAGUILA, Jorge (comp.) "Mario Vargas Llosa Entrevistas escogidas". Lima: Fondo Editorial Cultura Peruana, 2004, p.26).

${ }^{139}$ Acción Popular (ou Partido Político Acción Popular) é um partido político peruano, fundado em 7 de julho de 1956, por Fernando Belaúnde Terry, cuja ideologia é definida em seu Estatuto como "acciopopulista" (democrático, nacionalista, revolucionário), tendo "o Peru como doutrina". ${ }^{140}$ VARGAS LLOSA, Mario. [1978] "Liberdade de Informação e Direito de Crítica". In: Contra vento e maré. Rio de Janeiro: Francisco Alves, 1985, p. 284.

${ }^{141}$ Em 1975, o Peru era governado pelo general Francisco Morales-Bermúdez Cerruti, o segundo militar no poder após o golpe de 1968. Diante de uma série de protestos da população civil e do fracasso das reformas estruturais empreendidas pelo governo, convocou-se uma Assembleia Constituinte, em 1978, que foi presidida por Víctor Raúl Haya de la Torre, terminando desta forma a chamada "Revolução Peruana", encabeçada pelas forças armadas. É durante este processo, de levante civil contra o governo militar, que Vargas Llosa se pronuncia, em 1978, na sede da Acción Popular.
} 
popularização da cultura, a única coisa que alguém num juízo "democrático" não deveria "copiar" era justamente o sistema de informação, que havia se transformado num instrumento de propaganda a serviço do poder público ${ }^{142}$.

Podemos dizer que há uma mudança radical no conceito de modernização do escritor peruano. Nos anos sessenta, Vargas Llosa percebia no socialismo a possibilidade de modernização da sociedade latino-americana, principalmente no viés de superação das desigualdades. A partir de meados dos anos setenta, sua percepção caminha na direção oposta, formulando uma visão da modernização no sentido neoliberal. Assim, da utopia de uma América Latina integrada, Vargas Llosa passa a ressaltar não mais os traços comuns, mas os sujeitos numa perspectiva psicológica e o indivíduo numa acepção econômica. O escritor critica a compreensão da existência de personalidades supra-individuais, nacionais ou culturais, como, por exemplo, "o peruano", ou ainda as personalidades encarnadas de modo privilegiado em algum setor ou grupo, como, por exemplo, o índio. Nesse sentido está a sua crítica ao indigenismo e a José María Arguedas, em La utopía arcaica: José María Arguedas y las ficciones del indigenismo (1978). Neste ensaio, Vargas Llosa percebe no indigenismo um caráter antimoderno romântico que, como projeto, não tem a originalidade intelectual que reclama. Para o escritor peruano, não existe o indígena como coletivo, nem o índio como definição possível de um indivíduo e, consequentemente, o peruano. Para ele, trata-se de um essencialismo étnico que poderia resultar num tipo de racismo. A seu ver, os povos indígenas deveriam ascender à condição de cidadãos ${ }^{143}$.

Vargas Llosa elegeu a liberdade - identificada com a sociedade de livre mercado - como valor central de seu próprio pensamento político e valor literário. Poderíamos dizer que, na década de sessenta, a fonte de legitimação de sua noção de liberdade foi o pensamento de Sartre. Em fins da década de setenta, esta liberdade está claramente associada às noções do filósofo da ciência austríaco Karl Popper, do economista e filósofo austríaco Friedrich von Hayek e do filósofo político britânico de origem judaica russa Isaiah Berlin. Ao que compete aos dois últimos, Javier Franzé chama a atenção para a contradição da reivindicação simultânea de ambos os pensadores no câmbio das noções de liberdade e política

${ }^{142}$ VARGAS LLOSA, Mario. [1978] "Liberdade de Informação e Direito de Crítica”, p.286.

${ }^{143}$ FRANZÉ, Javier. "Vargas Llosa sobre Arguedas: la historia contra el historicismo". In: "Dossier: Mario Vargas Llosa”. Madrid: Cuadernos Hispanoamericanos, n.574, abr.1998, p. 25. 
de Vargas Llosa. Isto porque Friedrich von Hayek buscou desvincular a existência dos valores fundantes do liberalismo de toda intervenção humana, e Isaiah Berlin compreendeu o liberalismo basicamente como possibilidade de livre eleição racional de valores ${ }^{144}$.

No artigo "Isaiah Berlin, um héroe de nuestro tempo" (1980), Vargas declara que lendo o filósofo britânico pôde ver com clareza algo que percebia de maneira confusa:

o verdadeiro progresso, aquele que fez retroceder ou desaparecer os usos e as instituições bárbaras que eram fonte de infinitos sofrimentos para o homem e estabeleceram relações e estilos mais civilizados de vida, foi alcançado sempre graças à uma aplicação apenas parcial, heterodoxa, deformada, das teorias sociais. ${ }^{145}$

E, especifica que utiliza o plural ao falar de tais teorias, pois isto significa que diferentes sistemas ideológicos, às vezes irreconciliáveis, determinaram progressos idênticos ou semelhantes. Adiante, o escritor peruano ressalta que a palavra liberdade tem sido usada de duzentas maneiras diferentes. Dentre as quais Isaiah Berlin contribuiu com dois conceitos próprios para esclarecer esta noção: os de liberdade "negativa" e "positiva". Embora seja sutil a diferença, Vargas Llosa esclarece que esta distinção serve, sobretudo, para a compreensão do problema disfarçado por trás da artificiosa disjuntiva entre liberdades "formais" e liberdades "reais" 146.

O conceito "negativo" de liberdade, segundo Vargas Llosa, é mais individual que social e absolutamente moderno. Parte do pressuposto de que a soberania do indivíduo deve ser respeitada porque, em última instância, ela é a raiz da criatividade humana, do desenvolvimento intelectual e artístico, do progresso científico. A liberdade está estritamente ligada à coerção, àquilo que a nega ou a limita. Dessa forma, "se é mais livre na medida em que se encontra menos obstáculo para decidir sua vida segundo seu próprio critério". De acordo com Vargas Llosa, quanto menor for a autoridade que se exerça sobre a conduta do indivíduo, podendo esta ser determinada de maneira mais autônoma por suas próprias motivações - "minhas necessidades, ambições, fantasias pessoais" -, sem

\footnotetext{
${ }^{144}$ Ibidem, p.28.

${ }^{145}$ VARGAS LLOSA, Mario. [1980] “Isaiah Berlin, um Herói do Nosso Tempo”. In: Contra vento e maré. Rio de Janeiro: Francisco Alves, 1985.p.409.

${ }^{146}$ Ibidem, p.413-414.
} 
interferência de vontades alheias, maior é a liberdade ${ }^{147}$. Segundo o autor, coisas tão díspares como o romantismo literário, as ordens monásticas e o misticismo, algumas correntes anarquistas, a socialdemocracia, a economia de mercado e a filosofia liberal vinculam-se, além de suas grandes divergências, pois compartem esta noção de liberdade.

Enquanto a liberdade "negativa" quer, sobretudo, limitar a autoridade, a "positiva" quer assenhorar-se dela, exercê-la. De acordo com Vargas Llosa, esta noção é mais social que individual, pois se funda na ideia de que a possibilidade que cada indivíduo tem de decidir o seu destino está sujeita em boa medida às causas 'sociais' alheias à sua vontade. Para ele, enquanto a liberdade "negativa" leva em conta, principalmente, o fato de que os indivíduos são diferentes, a "positiva" considera antes de tudo o que eles têm de semelhante. Ao contrário daquela, para a qual a liberdade está mais preservada quanto mais se respeitam as variantes e casos particulares, a "positiva" estima que existe mais liberdade em termos sociais quanto menos diferenças se manifestam no corpo social, quanto mais homogênea é uma comunidade ${ }^{148}$. A seu ver, todas as ideologias e crenças totalizadoras, finalistas, convencidas de que existe uma meta última e única para uma dada coletividade - uma nação, uma raça, uma classe ou a humanidade inteira - compartem o conceito "positivo" da liberdade. Deste derivou-se uma quantidade de benefícios para o homem, e graças a ele existe a consciência social, compreendendo que as desigualdades econômicas, sociais e culturais são um mal corrigível e que podem e devem ser combatidos. Porém, de acordo com Vargas Llosa, este conceito de liberdade gerou suas próprias inequidades.

Hitler e Stalin podiam, sem exagerar demais, dizer que seus respectivos regimes estavam estabelecendo a verdadeira liberdade (a 'positiva') para seus povos. Todas as utopias sociais, de direita e de esquerda, religiosas ou laicas, fundam-se na noção 'positiva' da liberdade. ${ }^{149}$

Essas duas noções de liberdade são antagônicas, rechaçam-se reciprocamente, mas, para Vargas Llosa, não tem sentido procurar demonstrar que uma é verdadeira e a outra falsa, pois apesar de se servirem da mesma palavra, trata-se de coisas diferentes. A seu ver, este é um desses casos de 'verdades

\footnotetext{
${ }^{147}$ Ibidem, p.414.

${ }^{148}$ Ibidem, p.415

${ }^{149}$ Ibidem, p.415-416.
} 
contraditórias' ou de 'metas incompatíveis' que, segundo Isaiah Berlin, caracterizam a condição humana ${ }^{150}$. Uma constante no pensamento ocidental é acreditar que só existe uma resposta verdadeira para cada problema humano, e que uma vez dada esta resposta, todas as outras devem ser rechaçadas como erradas. Para Isaiah Berlin, estas crenças são falsas, e delas derivou-se boa parte das tragédias da humanidade. Segundo Vargas Llosa, deste ceticismo o professor Berlin extraiu alguns argumentos originais em favor da liberdade de escolha e do pluralismo ideológico ${ }^{151}$.

${ }^{150}$ Ibidem, p.416-417.

${ }^{151}$ Ibidem, p.410. 


\section{6. \\ Conclusão}

O pensamento crítico de Mario Vargas Llosa desenvolveu-se numa relação aproximada entre literatura e política. Ao longo dos anos sessenta e setenta, o escritor peruano desenha em seus artigos e ensaios uma percepção, seja de crítica literária ou de opiniões políticas, que fundamenta aquilo que compreende como o papel do intelectual, a função político-social da literatura e do escritor. Nos anos sessenta, marcado pelas utopias revolucionárias e pela concepção sartreana de literatura, o escritor peruano manifestava no plano político e ideológico sua adesão ao socialismo, ao mesmo tempo em que sustentava uma postura intelectual e literária comprometida com a época em que vivia. O compromisso do escritor (engagement) mobilizava Vargas Llosa em suas concepções literárias. Pode-se dizer que se trata de uma crença na palavra enquanto ação capaz de alterar as coisas no mundo, permitindo, além disso, a tomada de consciência do homem de si mesmo. Por meio de seus escritos, discursos e outras atividades, o escritor peruano denunciou violações aos direitos humanos, a prática da censura e a opressão.

Como demonstramos ao longo deste trabalho, a Revolução Cubana e o desenvolvimento do sistema literário latino-americano, entre as décadas de sessenta e setenta, corroboraram com a instituição de uma agenda coletiva que tinha como reflexão principal a ideia de América Latina integrada. Por meio de romances, contos, ensaios, correspondência e debates buscou-se a construção de uma representação política e cultural, com o intuito de valorizar as peculiaridades da região, promover a discussão sobre sua modernidade, bem como inserir a literatura produzida na América Latina nas inscrições universais. Escritores como Vargas Llosa, Gabriel García Márquez, Julio Cortázar, Carlos Fuentes, entre outros, mesmo vivendo no exílio ocuparam posições de destaque no campo social, político e cultural na América Latina. O exílio é uma das questões centrais para se compreender a maneira como os intelectuais pensavam a América Latina e percebiam sua função como intelectual. O olhar deslocado pelo exílio gerou uma perspectiva crítica, tanto da Europa como dos países do continente, trazendo grandes problemas e tensões, ao mesmo tempo em que abria diversas possibilidades de busca de soluções culturais, político-sociais e literárias. 
De acordo com Ángel Rama, em "La tecnificación narrativa" (1981), nas técnicas empregadas por Vargas Llosa em sua "resposta" ao impacto da modernização "convive o maior esforço de recuperação interna da experiência latino-americana com o maior esforço de adaptação cosmopolita, vinculando-as com uma extrema tensão que detecta sua vontade de escritor" ". Em Vargas Llosa poderíamos dizer que é esta a conflituosidade que se apresenta em sua cosmovisão. A experiência da modernidade tardia latino-americana pode ser percebida em seus discursos, que tangenciam os problemas básicos encontrados em sociedades periféricas ao lado de técnicas e crenças narrativas típicas dos países exportadores, ou ainda, de problemáticas coletivas ao lado de questões estritamente individuais.

Nos anos sessenta, Vargas Llosa manifestava uma perspectiva políticoliterária que ao longo do tempo adquirirá certa centralidade em suas formulações. Em primeiro lugar, Vargas Llosa afirma uma autonomia literária diante do campo político, formulando uma distinção entre o intelectual e o criador (escritor). Em segundo, o autor sustenta que a literatura é uma forma de insurreição permanente, um tipo de rebeldia diante do mundo "real", condição sine qua non para a criação de realidades verbais. Em terceiro, a vocação literária precipitaria uma rebeldia íntima, cujo protesto é inconsciente e singular. Por último, para o escritor peruano a liberdade de expressão é um valor fundamental - a partir de meados dos anos sessenta esta se configura como sua principal crítica aos sistemas socialistas.

A perspectiva literária de Vargas Llosa é sistematizada no ensaio Gabriel García Márquez: historia de un deicidio (1971), no qual o escritor peruano articula questões como obsessão, rebeldia e liberdade para explicar a natureza da literatura e a vocação do escritor. Contraditoriamente, o escritor peruano ressalta a irracionalidade/inconsciente na irrupção da vocação do escritor e nos temas de sua obra, e um caráter racional/objetivo que se manifesta nos critérios da forma no romance. Cabe recordarmos que o ensaio sobre a obra de García Márquez pode ser lido dentro do contexto das redes de sociabilidade do campo intelectual da época. Nesse sentido, o ensaio materializa a existência de um mercado profissional capaz de promover e legitimar novos cânones literários e representações simbólicas da América Latina.

${ }^{1}$ RAMA, Ángel. "La tecnificación narrativa”. Hispanoamérica, Gaithersburg, n.30, 1981, p. Ibidem, p.81. 
O ensaio de Vargas Llosa e suas ideias literárias foram amplamente contestados. Em 1969, o escritor colombiano Óscar Collazos criticou a dimensão dos "demônios" do romancista e a imagem do escritor em disputa com a realidade, formulados por Vargas Llosa, por compreender que se tratava de uma proposta intelectual escapista, uma forma de fechar deliberadamente os olhos para o contexto sociocultural e político latino-americano. Em grande medida, Collazos polemiza com o escritor peruano a partir de uma concepção de cunho políticoideológico que reflete as tensões do final da década de sessenta. Ao escritor colombiano incomodava as críticas de Vargas Llosa ao governo cubano. No final dos anos sessenta, o apoio inicial praticamente unânime da intelectualidade latinoamericana de esquerda à Revolução Cubana foi diminuindo na medida em que ocorria o endurecimento do regime e o progressivo alinhamento com a União Soviética. Assim, Vargas Llosa - que se tornaria nos anos oitenta um grande defensor do neoliberalismo - e outros escritores foram se distanciando do castrismo, principalmente após o "caso Padilla", em 1971. Para ele, a democracia e a liberdade estavam acima de todas as coisas. A participação protagonista de Vargas Llosa nas críticas ao governo revolucionário cubano e ao socialismo rendeu-lhe nos meios de esquerda o rechaço de suas obras e concepções literárias. Porém, a polêmica mais extensa a respeito da teoria dos "demônios" foi sustentada entre Vargas Llosa e Ángel Rama, em 1972. Neste debate, para além das tensões políticas, evidenciavam-se leituras e projetos intelectuais distintos, expressando concepções díspares sobre a modernização e o exercício da crítica literária na América Latina. Ademais, este debate aproxima-nos dos desafios e conflitos no âmbito cultural da época.

Vargas Llosa progressivamente afastou-se das ideias de Sartre sobre a literatura. No que diz respeito à noção de liberdade poderíamos dizer que o escritor peruano cambiou da liberdade em Sartre para a liberdade neoliberal. Ainda assim, permaneceu de sua relação com o pensamento do filósofo francês uma atitude geral perante a literatura como uma produção artística de fundamental importância para a sociedade, e o sentido de liberdade que deve exigir o escritorintelectual para o exercício da sua vocação. Na contemporaneidade, Vargas Llosa mantém uma postura intelectual atuante, posicionando-se criticamente diante das perspectivas políticas, ideológicas e literárias. 


\section{7. \\ Referências bibliográficas}

\section{A. Obras, artigos e entrevistas de Vargas Llosa}

É possível pensar o mundo sem o romance?. In: MORETTI, Franco (org.). A cultura do romance. São Paulo: Cosac Naify, 2009.

Peixe na água: memórias. São Paulo: Companhia das Letras, 1994.

As verdades das mentiras. São Paulo: Arx, 2004.

Contra viento y marea I (1962-1972). Barcelona: Seix Barral, 1986.

Contra viento y marea II (1972-1983). Barcelona: Seix Barral, 1986.

Contra viento y marea III (1964-1988). Barcelona: Seix Barral, 1990.

Contra vento e maré. Rio de Janeiro: Francisco Alves, 1985.

Cartas de Batalla por Tirant lo Blanc. Madrid: Santillana Ediciones Generales/Punto de lectura, 2011.

Dicionário Amoroso da América Latina. Rio de Janeiro: Ediouro, 2006.

La ciudad y los perros. $3^{\mathrm{a}}$ ed. Barcelona: Seix Barral, 1985.

García Márquez: história de un deicidio. Barcelona: Barral Editores, 1971.

Literatura y política. Madrid: Fondo de Cultura Económica de España, 2003.

Garcia Marquez: de Aracataca a Macondo. In: BENEDETTI, Mario (org.). Nueve asedios a García Márquez, Santiago de Chile: Editorial Universitaria, 1969.

Cartas a um jovem escritor. Rio de Janeiro: Elsevier, 2006.

Entrevistas

CANO GAVIRIA, Ricardo. El buitre y el ave fénix, conversaciones com Mario Vargas Llosa. Barcelona: Editorial Anagrama, 1972.

Diálogo en Madrid. Cuadernos Hispanoamericanos, Madri, n. 572, fev. 1998.

Dos entrevistas con Mario Vargas Llosa. Optimismo de la historia. Cuadernos Hispanoamericanos, Madri, n. 574, abr. 1998.

Jorge Coagila (comp.). Mario Vargas Llosa Entrevistas escogidas. Lima: Fondo Editorial Cultura Peruana, 2004.

LORENZ, Günter W. Diálogo com a América Latina: panorama de uma literatura do futuro. São Paulo: Editora Pedagógica Universitária, 1973.

SETTI, Ricardo. Conversa com Vargas Llosa. São Paulo: Brasiliense, 1986.

\section{B. Revistas consultadas}

Marcha, Montevidéu

n. 998 , fev.1960.

n. 1089 , dez.1961.

n. 1193 , fev. 1964 .

n. 1194 , fev.1964.

n. 1217, ago. 1964 .

n. 1245 , fev. 1965 .

n. 1306, jun. 1966 . 
Mundo Nuevo, Paris

n. 01, jul.1966.

n. 03, set.1966.

n. 05 , nov.1966.

Casa de las Américas, Havana, n. 35, mar-abr. 1966.

Revista Iberoamericana, v. 37, n. 76-77, jul-dez. 1971.

Punto de Vista, n. 25, dez.1985.

Cuadernos Hispanoamericanos, Madri, n. 574, abr. 1998.

Cuadernos Hispanoamericanos, Madrid, n.574, abr.1998.

\section{B. Obras Gerais}

ACHUGAR, Hugo. Planetas sem boca: escritos efêmeros sobre Arte, Cultura e Literatura. Belo Horizonte: Editora UFMG, 2006.

AGUIAR, Flávio; RODRIGUES, Joana (org.). Um transculturador do futuro. Belo Horizonte: Editora UFMG, 2013.

ALBURQUERQUE FUSCHINI, Germán. La red de escritores latinoamericanos en los años sesenta. Revista Universum, Chile, Universidade de Talca, n. 15, 2000 .

El caso Padilla y las redes de escritores latinoamericanos. Revista Universum, Chile, Universidade de Talca, n. 16, 2001.

ALCÁNTARA ALMÁZAR, José. Narrativa y sociedade en Hispanoamérica. Santo Domingo: Intec, 1984.

BARTHES, Roland. "A morte do autor". In: BARTHES, Roland. O rumor da língua. São Paulo: Martins Fontes, 2004.

BENEDETTI, Mario (org.). Nueve asedios a García Márquez, Santiago de Chile: Editorial Universitaria, 1969.

BENJAMIN, Walter. "O autor como produtor". In: A modernidade. Lisboa, Assírio \& Alvim (Obras escolhidas de Walter Benjamin), 2006.

CAMUS, Albert. O homem revoltado. $9^{a}$ Ed. Rio de Janeiro - São Paulo Editora Record, 2011.

CANDIDO, Antonio. Formação da literatura brasileira (momentos decisivos) $6^{\mathrm{a}}$ ed. Belo Horizonte: Editora Itatiaia Ltda, 2000.

Literatura e sociedade: estudos de teoria e história literária.

São Paulo: T. A. Queiroz, 2000.

COLLAZOS, Óscar; Cortázar, Julio; Vargas Llosa, Mario. Literatura en la revolución y revolución en la literatura, México: Siglo XXI, 1970.

CORNEJO POLAR, Antonio. Hipótesis sobre la narrativa peruana última. In: La novela peruana. $2^{\mathrm{a}}$ ed. Lima: Editorial Horizonte, 1989.

Para una teoria literaria hispanoamericana: a vinte años de un

debate decisivo. Revista de Critica Literaria Latinoamericana, ano XXV, n.50, Lima- Hanover, $2^{\circ}$ semestre de 1999.

COSTA, Adriane A. Vidal. Intelectuais, Política e Literatura na América Latina: o debate sobre revolução e socialismo em Cortázar, García Márquez e Vargas Llosa (1958-2005). 413 f. Tese (Doutorado em História) - Programa de PósGraduação do Departamento de História da Faculdade de Filosofia e Ciências Humanas da Universidade Federal de Minas Gerais, 2009.

CUNHA, Roseli Barros. Transculturação narrativa: seu percurso na obra crítica de Ángel Rama. São Paulo: Humanitas Editorial, 2007. 
DELEUZE, Gilles; GUATTARI, Félix. Mil platôs: capitalismo e esquizofrenia. Vol. 1. $1^{\text {a }}$ ed. Rio de janeiro: Editora 34, 1995.

DÍAZ CABALLERO, Jesús. Angel Rama o la crítica de la trasculturación. Ultima entrevista. Lima: Lluvia Editores, 1991.

DONOSO, José. Historia personal del boom. Barcelona: Seix Barral, 1983.

FERNÁNDEZ MORENO, César (coord.). América Latina em sua literatura. São Paulo: Perspectiva, 1972.

FERNÁNDEZ RETAMAR, Roberto. Para una teoría de la literatura hispanoamericana y otras aproximaciones. Bogotá: Instituto Caro y Cuervo, 1995.

FLUSSER, Vilém. A dúvida. São Paulo: Annablume, 2011.

FRANZÉ, Javier. Vargas Llosa sobre Arguedas: la historia contra el historicismo. In: Dossier: Mario Vargas Llosa. Cuadernos Hispanoamericanos, Madrid, n.574, abr.1998.

FREUD, Sigmund. Escritores Criativos e Devaneio. In "Gadiva" de Jensen e outros trabalhos. Edição Standard Brasileira das Obras Psicológicas Completas de Sigmund Freud - Vol. IX. Rio de Janeiro: Imago Ed., 1986.

O Eu e o ID, "Autobiografia" e outros textos [1923-1925].

Obras Completas - Vol. XVI. São Paulo: Companhia das Letras, 2014.

FUENTES, Carlos. El afán totalizante de Vargas Llosa. In: La nueva novela hispanoamericana. México: Joaquín Mortiz, 1969.

GARCÍA Márquez, Gabriel; VARGAS LLOSA, Mario. La novela en América Latina: Diálogo. Lima: C.M. Batres, Universidad Nacional de Ingenieria, 1967.

GARCÍA MÁRQUEZ, Gabriel. [1967]. Cem anos de solidão. $48^{\mathrm{a}}$ ed. Rio de Janeiro: Editora Record.[s. d.].

GILMAN, Claudia. Entre la pluma y el fusil: debate y dilemas del escritor revolucionário en América Latina. Buenos Aires: Siglo XXI, 2003.

GONZÁLEZ BERMEJO, Ernesto. Conversas com Cortázar. Rio de Janeiro: Jorge Zahar, 2002.

GRAMSCI, Antonio. Os intelectuais e a organização da cultura. Rio de Janeiro: Civilização Brasileira, 1995.

HARSS, Luis. Los nuestros. Buenos Aires: Sudamericana, 1969.

HOLLANDA, Diogo. "Ernesto Sabato entre a glória e o desprezo". Revista Garrafa, n. 24, vol. II, mai-ago. 2011.

ISER, Wolfgang. O Fictício e o Imaginário: Perspectivas de uma Antropologia Literária. Rio de Janeiro: Eduerj, 1996.

JONSSON, Petter. Tres lecturas de las novelas de Mario Vargas Llosa: Interpretación psicoanalítica de la producción novelesca de un autor. Suécia: Lunds Universitet, Språk-och Litteraturcentrum Spanska. Série Études Romanes de Lund 86, 2009.

KRISTAL, Efraín. Temptation of the Word. Nashville: Vanderbilt University Press, 1998.

La política y la crítica literaria. El caso Vargas Llosa. Perspectiva, Universidad de Chile, vol. 4, n. 2, 2001.

KRISTEVA, Julia. Introdução à semanálise. $2^{\mathrm{a}}$ ed. São Paulo: Perspectiva, 2005. LEOPOLDO E SILVA, Franklin. Literatura e experiência histórica em Sartre: o engajamento. In: Revista Doispontos. Curitiba, São Carlos, vol. 3, n. 2, outubro, 2006.

LUCENA. Karina de Castilhos. Macondo: Além da terra firme(Um estudo sobre a cidade imaginária). 122 f. Dissertação (Mestrado em Letras) - Programa de 
pós-graduação em Letras e Cultura Regional da Universidade de Caxias do Sul RS, 2008.

MARCO, Joaquín. Nueva literatura en España y en América. Barcelona: Lumen, 1972.

MARTIN, Gerald. Gabriel García Márquez: uma vida. Rio de Janeiro: Ediouro, 2010.

MENTON, Seymour. La Guerra contra el fanatismo de Mario Vargas Llosa. University of California, Irvine. AIH. Actas X, Centro Virtual Cervantes ,1989.

MIGUEL OVIEDO, José. Mario Vargas Llosa: la invención de una realidad. Barcelona: Seix Barral, 1982.

. Dossier Vargas Llosa. Lima: Taurus/Santillana, 2007.

MISKULIN, Silvia Cezar. Cultura e política na Revolução Cubana: a importância de Lunes de Revolución. São Paulo: Anais Eletrônicos do III Encontro da ANPHLAC, 1998.

MOISÉS, Massaud. Dicionário de termos literários. 12.ed.rev e ampl. São Paulo: Cultrix, 2004.

MOREJÓN ARNAIZ, Idalia. Política y polémica en América Latina: Las revistas Casa de las Américas y Mundo Nuevo. México: Ediciones de Educación y Cultura (Colección Polémicas), 2010.

MYERS, Jorge. Músicas distantes. Algumas notas sobre a história intelectual hoje: horizontes velhos e novos, perspectivas que se abrem. In: SÁ, Maria Elisa Noronha de (org.). História intelectual latino-americana: itinerários, debates e perspectivas. Rio de Janeiro: Ed. PUC-Rio, 2016.

NEPOMUCENO, Eric. Gabriel García Márquez: duas anotações para um perfil. In: GARCÍA MÁRQUEZ, Gabriel. Cem anos de solidão. Rio de Janeiro: Record, 2009.

OLIVEIRA, Renata Peixoto de. Venezuela e os antecedentes de uma Política Externa ativa: petróleo e democracia como elementos da Política Externa do regime de Punto Fijo. Revista do IMEA-UNILA (RevIU). Vol. 1, n. 2, 2013.

PATULA, Jan. Europa del Este: del stalinismo a la democracia. México: Siglo XXI, 1993.

PINHEIRO DA SILVA, Marcio. R. As ambivalências textuais de Roland Barthes. Acta Scientiarum: human and social sciences, Maringá, v. 25, n. 1, 2003.

PIZARRO, Ana (org.). América Latina: palavra, literatura e cultura, vol 3, 1995. . El sur y los trópicos. Ensayos de cultura latinoamericana.

Alicante: Universidad de Alicante, 2004.

RAMA, Ángel; Vargas Llosa, Mario. García Márquez y la problemática de la novela. Buenos Aires: Corregidor - Marcha, ediciones, 1973.

RAMA, Ángel. Rubén Darío y el modernismo: Circustancia socioeconómica de un arte americano. Caracas: Universidade Central de Venezuela, 1970.

La tecnificación narrativa. Hispanoamérica, Gaithersburg, n.30,

1981.

junho de 2005 .

El boom en perspectiva. In: Signos Literarios, n. 01, janeiro-

Diez problemas para el novelista latinoamericano. In: Crítica literaria y utopía en América Latina. Medelín: Editorial Universidad de Antioquia, 2005.

Transculturación narrativa en América Latina. $2^{\mathrm{a}}$ ed. Buenos Aires: Edições El Andariego, 2008.

A Cidade das Letras. São Paulo: Boitempo, 2015. 
SABATO, Ernesto. El Escritor y sus fantasmas. $2^{\mathrm{a}}$ Ed. Buenos Aires: Aguilar, 1964.

SADER, Emir; JINKINGS, Ivana; NOBILE, Rodrigo; MARTINS, Carlos Eduardo. (Coords.). Enciclopédia Contemporânea da América Latina e do Caribe. São Paulo: Boitempo editorial, 2006.

SÁNCHEZ, Pablo. La emancipación engañosa: Una crónica transatlántica del boom (1963-1972). Murcia: Cuadernos de América sin nombre, n.25, 2009.

SARLO, Beatriz. Intelectuales y revistas: razones de uma práctica. In: Les discours culturel dans les revues latino-américaines de 1940 à 1970. América, Cahiers du Criccal, n. 9-10, Paris, Presses de la Sorbonne Nouvelle-Paris 3, 1992. SARLO, Beatriz. Intelectuales: ¿Escisión o mimesis?. Punto de Vista, n. 25, dez.1985.

SARTRE, Jean-Paul. O escritor não é político. Lisboa: Publicações Dom Quixote (Coleção Vector - 6), 1971. . As palavras. Rio de Janeiro: Nova Fronteira, 1984.

Filosóficos), 2005. Que é a literatura?. Petrópolis, RJ: Vozes (Coleção Textos O ser e o nada: Ensaio de ontologia fenomenológica. $15^{\mathrm{a}}$ ed. Petrópolis, RJ: Vozes, 2007.

O Existencialismo é um Humanismo. $4^{\mathrm{a}}$ ed. Petrópolis, RJ: Vozes (Vozes de bolso), 2014.

SCHNEIDER, Daniela Ribeiro. "O Método Biográfico em Sartre: contribuições do Existencialismo para a Psicologia”. Estudos e pesquisa em Psicologia, UERJ, $R J$, ano 8, n.2, $1^{\circ}$ semestre de 2008.

SILVA, Helenice Rodrigues da. Fragmentos da história intelectual: entre questionamentos e perspectivas. Campinas: Papirus, 2002.

SOUZA, Thana Mara. Da estética à ética: uma análise compreensiva das obras literárias de Sartre e Malraux. 335 f. Tese (Doutorado em Filosofia) - Programa de Pós-Graduação do Departamento de Filosofia da Faculdade de Filosofia, Letras e Ciências Humanas da Universidade de São Paulo, 2008.

TODOROV, Tzvetan. As estruturas narrativas. São Paulo: Perspectiva, 2006.

VANDEN BERGHE, Kristine. Hacia una cartografia del Boom. Una polémica en Zona Franca (ag.-dic.1972). In: Les discours culturel dans les revues latinoaméricaines de 1970 à 1990. América, Cahiers du Criccal, nº 15, Paris, 1996.

VIEIRA, Beatriz de Moraes. Cidades literárias, realidades traumáticas. O Olho da História, n. 14, Salvador (BA), junho de 2010.

VIEIRA, Felipe de Paula Góis, De Macondo a McOndo: os limites do Real Maravilhoso como discurso de representação da América Latina (1947-1996). 148 f. Dissertação (Mestrado em História) - Instituto de Filosofia e Ciências Humanas da Universidade Estadual de Campinas, 2012

VILLAÇA, Mariana Martins. O Instituto del Arte e Industria Cinematográficos (ICAIC) e a política cultural em Cuba (1959-1991). 434 f. 2 v. Tese. FFLCH (Departamento de História), USP, São Paulo, 2006.

VOLEK, Emil. José Martí, Nuestra (Macondo) América. In: Revista Universum, n. 22, vol. I, 2007.

WILLIAMS, Raymond L. Vargas Llosa: outra historia de un deicidio. México: Taurus, 2001. 